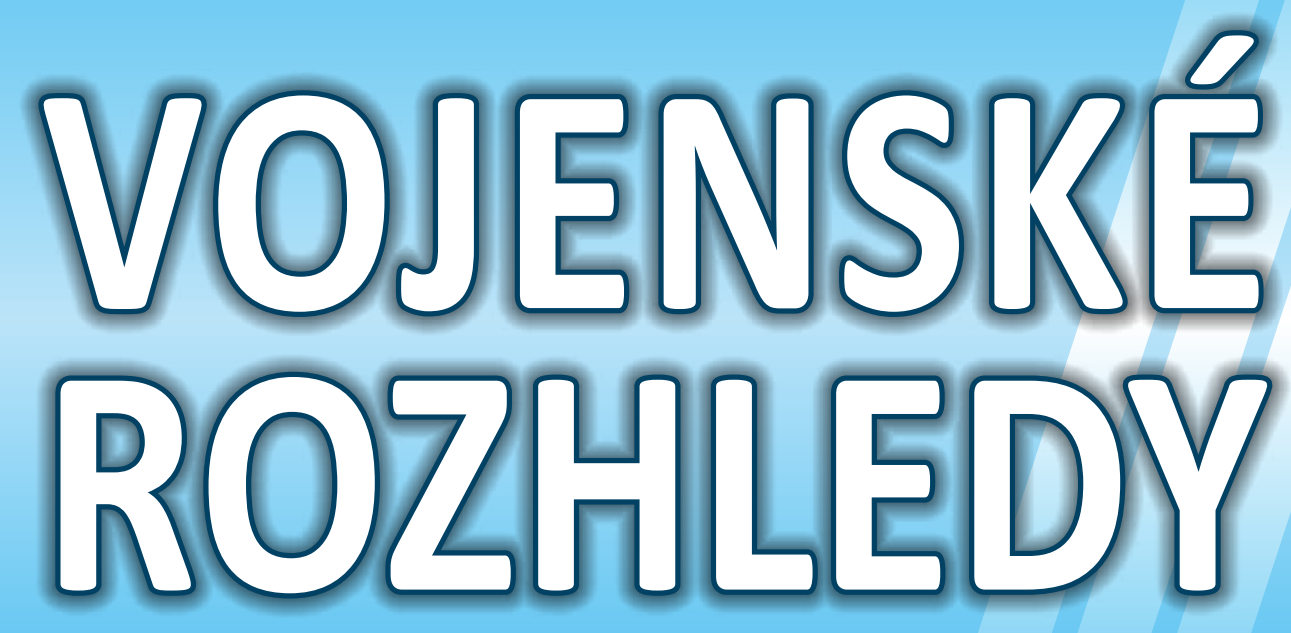

Czzech Midilitarsy Revilew
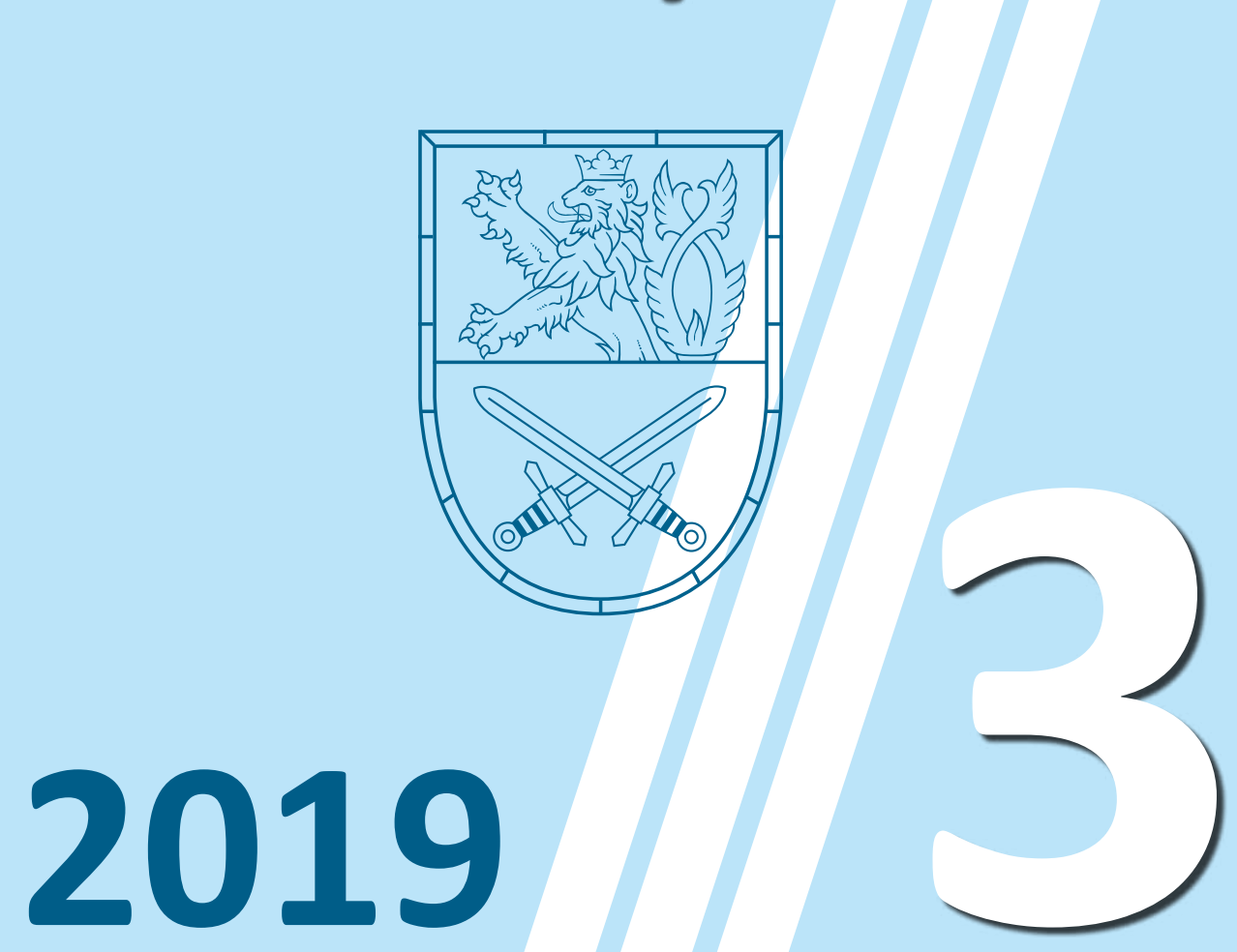


\section{VOJENSKOTEORETICKÝ ČASOPIS}
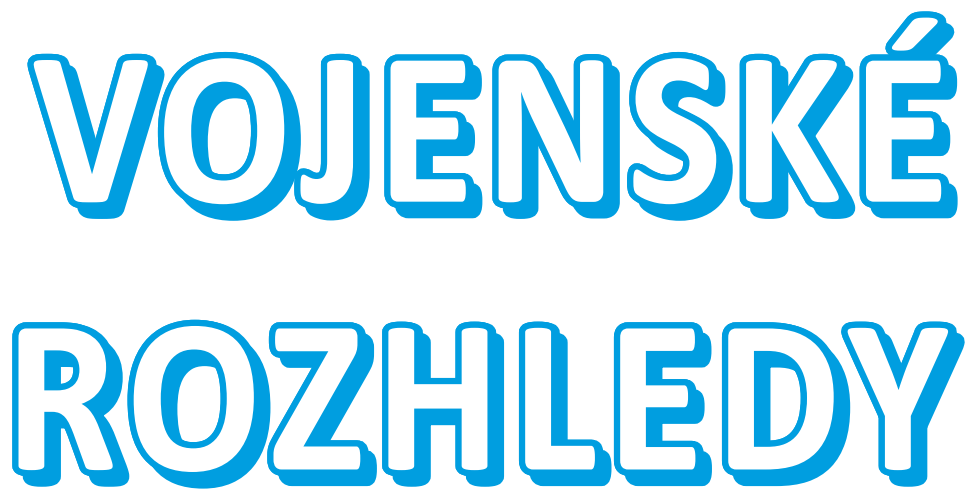

ROČNÍK 28 (60) 



\section{Jihadist Foreign Terrorist Fighters: Contemporary Threats and Challenges in East Central Europe}

\section{Džihádističtí zahraniční terorističtí bojovníci: soudobé hrozby a výzvy ve středovýchodní Evropě}

\section{Miroslav Mareš}

Abstract: This paper deals with the phenomenon of Jihadist foreign terrorist fighters from the perspective of East Central European countries. Over the past decade, the term 'foreign terrorist fighter' has become established in scholarly literature, international law and the popular consciousness. Today, Jihadist foreign terrorist fighters are closely watched globally for the security threat they pose. Although the greatest danger in Europe is seen to be to nations in the west, several cases in East Central Europe - involving terrorists travelling through the region and attempting to radicalise local jihadists - have led Poland, Hungary, Slovakia and the Czech Republic to adopt important legislation to eliminate this threat.

Abstrakt: CClánek se zabývá fenoménem džihádistických zahraničních teroristických bojovníků z perspektivy zemí středovýchodní Evropy. V odborné literatuře i v mezinárodním právu se pojem „zahraniční teroristický bojovník etabloval“ v posledním desetiletí. V současnosti jsou v globálním rámci sledovanou entitou džihádističtí zahraniční terorističtí bojovníci. Představují bezpečnostní hrozbu i pro země Visegrádské skupiny, a to jak z hlediska cestování pres jejich území, tak i z hlediska radikalizace domácích džihádistů. Několik dosavadních případů v zemích středovýchodní Evropy však zatím nepředstavuje tak závažnou hrozbu, jakou je tento fenomén v západní Evropě. Nicméně Polsko, Mad’arsko, Slovensko i Česká republika přijaly důležitá legislativní opatření k eliminaci této hrozby.

Key words: Foreign Terrorist Fighters; Jihadism; Counter-terrorism; East Central Europe; Inter-Agency Cooperation.

Klíčová slova: Zahraniční terorističtí bojovníci; boj proti terorismu; středovýchodní Evropa; meziresortní spolupráce. 


\section{INTRODUCTION}

In recent political discourse in East Central Europe, Jihadist terrorist foreign fighters have been discussed as a serious security threat. The aim of this paper is to analyse the various dimensions of this threat and to explain how it has challenged recent legislation and security structures in the region. In this paper, East Central Europe is understood to cover the so-called Visegrád Group countries (Poland, the Czech Republic, Slovakia, Hungary). The impact of global and European influences on the situation in the centre of the "old continent" is taken into account.

The paper starts with methodological and conceptual issues. The development of the phenomenon of Jihadist foreign fighters in relation to East Central Europe is described with the aim of explaining the recent new dimension of the threat. The following part deals with the reaction of the legal sphere within the global and European context of law changes. Specific challenges posed by Jihadist foreign fighters to the security systems in V4 countries are discussed with the aim of formulating basic recommendations for policy makers.

The complex character of the researched subject and the specific points discussed in individual sections below require a broad spectrum of methodological approaches. The historical method and description is used for an overview of the development of the issue of foreign terrorist fighters from an East Central European point of view. A risk and threat analysis serves as an assessment of the recent situation. Simple legal logic is applied in the section about legal changes. Basic strategic and policy analyses are used in relation to strategic culture and infrastructure.

\section{CONCEPTUALISING FOREIGN FIGHTERS}

The first very important challenge is that of conceptualising and defining Jihadist foreign terrorist fighters. Analytically, we can divide this composite term into three parts. Firstly, the "traditional" concept of "foreign fighters" will be described. Secondly, the specific dimension of foreign "terrorist“ fighters (in contrast to „non-terrorist" foreign fighters) will be explained and, thirdly, „Jihadist“ foreign fighters will be distinguished from other variants.

The concept of foreign fighters has been widely and broadly discussed in recent literature, however, a generally accepted definition, or a list of criteria, has not been created (which is typical of many crucial terms in the social sciences). In this article, we start with a basic working definition taken from the book by David Malet. He defines foreign fighters as „non-citizens of conflict states who join insurgencies during civil conflicts“. ${ }^{1}$

1 MALET, David. 2013. Foreign Fighters. Transnational Identity in Civil Conflicts, Oxford University Press, Oxford. 
Malet excludes from his definition members of foreign governmental forces involved in a civil conflict ${ }^{2}$ as well as mercenaries and contractors. However, the line between voluntary participation and providing a service for remuneration is in many cases unclear. To improve the definition, the consideration of the strong role played by voluntary participation due to identifying with the goal of the warring party should be added (and a significant pecuniary motivation is not excluded).

Malet's criterion of "insurgencies" is questionable. ${ }^{3}$ Firstly, due to the difficult identification of insurgency in recent conflicts (where for example many non-state armed groups fight in symmetrical conflicts); and secondly, due to the fact that foreign volunteers can also join the governmental forces in the conflict. ${ }^{4}$ The issue of non-citizenship can also be questioned, in cases when the fighters are granted citizenship of the state or quasi-state for which they fight. ${ }^{5}$

In the light of these facts, in this article foreign fighters are defined as persons who predominantly take part voluntarily in a warring faction in an armed conflict outside the country of their residence and who do not serve in the conflict area as members of their own country's military or other security forces. Voluntary participation distinguishes them from mercenaries and contractors (with respect to the flexible definitions of these categories). Service in the armed units of warring factions and not in the armed or other security forces of their home state distinguishes them from participants in foreign interventions or peace-enforcement or peace-keeping missions of the international community.

In Malet's above-mentioned definition, the issue of a diaspora is missing. In fact, we can distinguish between foreign fighters from a diaspora with a direct link to a warring party (for example, people from the second generation of emigrants who belonged to the ethnic group whose representatives are fighting in a civil war) and foreign fighters without previous close ties to the geopolitical area of the conflict. In the case of Islamist foreign fighters the construction of the „global Ummah“ plays an important role and Islamist fighters may feel a connection to all territories claimed by Islamists. Hegghammer distinguishes between foreign fighters from the same region as the conflict (for example,

2 He considers the real situation, not the possible officially presented but false information about alleged volunteers, who are in fact members of regular forces (as, for example, the combatants from the German and Italian armed forces who were involved in the Spanish Civil War). Ibid.

3 In a similar way, Thomas Hegghammer uses the criterion of insurgency. He works with four criteria, defining a foreign fighter "as an agent who (1) has joined, and operates within the confines of, an insurgency, (2) lacks citizenship of the conflict state and kinship links to its warring factions, (3) lacks affiliation to an official military organisation, and (4) is unpaid." HEGGHAMMER, Thomas. 2010. The Rise of Muslim Foreign Fighters: Islam and the Globalization of Jihad. International Security, Vol. 35, No. 3 (Winter 2010/11), pp. 53-93.

4 As foreign volunteers in governmental forces in Ukraine, for example. See MAREŠ, Miroslav. Czech Foreign Fighters in the Ukrainian Conflict: Legal Aspects and Propagandist Use. Vojenské rozhledy. Vol. 26, special issue: 71-82, doi:10.3849/2336-2995.26.2017.05.071-082.

5 RAČIUS, Egdūnas. 2017. Caliphate Citizens. In REKAWEK, Kacper: Not Only Syria? The Phenomenon of Foreign Fighters in a Comparative Perspective. Amsterdam: IOS Press, 52-59. 
Pakistanis fighting in Afghanistan) and global foreign fighters (they travel to conflict zones from different regions, for example Algerian fighters in Afghanistan). ${ }^{6}$

\section{CONCEPTUALISING FOREIGN TERRORIST FIGHTERS}

While the phenomenon of "foreign fighters" and the term itself are relatively old, the newly coined term „foreign terrorist fighters“ (FTFs) was created in international politics and law. This term is used in international as well as national legal documents; however, it is not precisely defined in international law. ${ }^{7}$ The definition of foreign terrorist fighters is included in „The Hague-Marrakech Memorandum on Good Practices for a More Effective Response to the FTF Phenomenon“, which was adopted by the Foreign Terrorist Fighters Initiative of the Global Counterterrorism Forum. FTFs are defined as „individuals who travel abroad to a state other than their states of residence or nationality to engage in, undertake, plan, prepare, carry out or otherwise support terrorist activity or to provide or receive training to do so (often labelled as 'terrorist training')."8

The word "terrorist" in this definition is mostly linked with the preparation of terrorist acts. However, it is also important to take into account the character and labelling of an armed group. Individually, foreign fighters might take part in military combat only (insurgency, symmetrical battles with various types of weapons, including heavy weapons), while their organisations are nevertheless also responsible for terrorist activities. These fighters can also be directly engaged in terrorist or repressive activities in the area of the combat (atrocities aimed against religious or ethnic groups, perpetrated against prisoners of war etc.). They make use of these various experiences to commit crimes after their return (the so-called „returnees", including their family members, are a serious concern in Western countries today).

Foreign terrorist fighters are considered a security threat due to their direct participation in armed conflicts and linked atrocities (executions of prisoners, rape of women representing specific groups etc.), their potential to radicalise other people (from the conflict area or after their return) and their potential to be involved in terrorist or other violent activities after their return. However, not all returnees are a priori terrorists. Dutch expert Jeanine de Roy van Zuijdewijn divides foreign fighters from the Western point of view into several categories included in the following schema - table 1.

6 HEGGHAMMER 2010.

7 BíLKOVÁ, Veronika. 2018. Foreign Terrorist Fighters and International Law. Groningen Journal of International Law. Vol 6, No 1: 1-23. DOI: 10.21827/5b51d51a22ac3.

8 FOREIGN TERRORIST INITIATIVE, GLOBAL COUNTERTERRORISM FORUM. 2014. The HagueMarrakech Memorandum on Good Practices for a More Effective Response to the FTF Phenomenon. Available at: https://www.thegctf.org/documents/10162/140201/14Sept19_ The+Hague-Marrakech+FTF+Memorandum.pdf. 
Table 1: Typology of foreign fighters according to Jeanine de Roy van Zuijdewijn

\begin{tabular}{|l|l|}
\hline Martyr & $\begin{array}{l}\text { A foreign fighter who joins a conflict and is killed on the battlefield. He or she will pose no } \\
\text { further risk to the country of origin unless the martyrdom itself is used as a recruiting tool. }\end{array}$ \\
\hline Veteran & $\begin{array}{l}\text { An experienced fighter who continues fighting in other theatres of conflict. He sees jihad } \\
\text { as a way of life. While he is a risk to people in conflict zones, he is no risk to the country of } \\
\text { origin in the West. }\end{array}$ \\
\hline Recruiter & $\begin{array}{l}\text { The recruiter is usually a former foreign fighter who returned home to recruit others to } \\
\text { fight, often quite successfully because of his or her 'street credibility'... Generally speaking, } \\
\text { they are not directly involved in terrorist activity but are frequently seen as spiritual guides } \\
\text { to future terrorists. They are an indirect risk by constantly 'feeding' the local Jihadist } \\
\text { community. }\end{array}$ \\
\hline $\begin{array}{l}\text { Reintegrated } \\
\text { fighter }\end{array}$ & $\begin{array}{l}\text { He/she is the one-time foreign fighter. After the conflict or his role in it has ended, the rein- } \\
\text { tegrated fighter will return and resume his pre-departure life or will at least not be involved } \\
\text { in terrorist activity...They are usually no risk to the country of origin. }\end{array}$ \\
\hline Terrorist & $\begin{array}{l}\text { When he/she comes into contact with terrorist networks in conflict zones, he/she becomes } \\
\text { convinced that it is not only a priority to fight for the oppressed abroad, but also to target } \\
\text { the country of origin. This type of foreign fighter not infrequently converts to Islam, under- } \\
\text { goes the most fundamental shift in identity and norms and poses a direct threat to the } \\
\text { country of origin. }\end{array}$ \\
\hline
\end{tabular}

Source: ZUIJDEWIJN, Jeanine de Roy van. The Foreign Fighters' Threat: What History Can (not) Tell Us. Perspectives on Terrorism, vol. 8, No. 5: 59-73, http://www.terrorismanalysts.com/pt/index.php/pot/article/view/378/html

Family members (women, children) are also sometimes affiliated with foreign fighters. Women may travel to conflict areas individually with non-combatant goals (mostly to marry Jihadists) and may take part in combat. Some of these women's activities are on the boundary between combatant and non-combatant categories (for example, in religious militias enforcing Sharia law). Child soldiers under the command of Jihadist terrorists constitute another category. ${ }^{9}$

Foreign fighters have been engaged in several recent armed conflicts. The term „terrorism" is used, misused and relativised in relation to various categories of foreign fighter (on both sides of the conflict in the Donbass, on the Kurdish side in the Syrian war ${ }^{10}$ etc.). This article deals only with Jihadist foreign fighters. Jihadism is understood as a fanatic religious-ideological motive for militant violent struggle in the name of Islam against enemies (who can also be Muslims who are designated as "takfir", as apostates). ${ }^{11}$

In his research into developments until 2015, Raphaël Leduc found that „the presence of foreign fighters does not raise the likelihood that a terrorist plot will be executed and if it is, then they have no impact on the number of casualties as a consequence of that plot. Overall, this means that foreign fighters do not increase the operational

9 SUŠOVSKÁ, Patricie. 2107. Dětští vojáci v propagandě Islámského státu - proměny v čase. In BUREŠ, Oldřich (ed.): Sborník vybraných príspěvků z 9. výroční studentské konference bezpečnostního výzkumu. Praha: Metropolitan University Prague Press, 48-57. Available at: https://www.c4ss.cz/wp-content/uploads/2017/11/Sbornik-studentska-konference-2017.pdf.

10 ORTON, Kyle. 2017. The Forgotten Foreign Fighters: The PKK in Syria. London: The Henry Jackson Society. Available at: http://henryjacksonsociety.org/wp-content/uploads/2017/08/3053-PYDForeign-Fighter-Project-1.pdf.

11 SCHMIDINGER, Thomas. 2015. Jihadismus. Ideologie, Prävention und Deradikalisierung. Wien: Mandelbaum Verlag. 
effectiveness of a terrorist cell in a way that is different from any other member of the population that joins the cell. “12 However, several cases of terrorist attacks committed by returned foreign fighters under the umbrella of the so-called Islamic State (in Paris and Brussels) make this kind of terrorist returnee with Islamic State links a matter of specific concern. ${ }^{13}$

\section{DEVELOPMENT OF THE PHENOMENON OF JIHADIST FOREIGN FIGHTERS FROM THE EAST CENTRAL EUROPEAN POINT OF VIEW}

Muslim (not only Jihadist) foreign fighters have fought in many historical conflicts. The modern phenomenon of Jihadist FTFs can be divided into four main historical waves. The first wave was initiated by the Soviet invasion of Afghanistan. Jihadists from various countries resisted the Soviet occupation forces and the Afghan government in the $1980 \mathrm{~s}$ and some of them turned to terrorist activities against the West in the early $1990 \mathrm{~s}$ (the term „mujahideen“ was popularised at that time). The second wave is connected mostly with Jihadist volunteers in the Balkan and Caucasian wars of the $1990 \mathrm{~s}$. The third wave started after US campaign in Afghanistan in 2001 and especially of Iraq in 2003. The fourth wave was caused by the outbreak of civil war in Syria in 2011; the proclamation of a "Caliphate“ by the Islamic State had a specific impact on its intensification (however, foreign fighters were - or still are - also engaged in other Islamist groups in the area). This categorisation is very simplified; there are conflicts with limited numbers of Jihadist foreign fighters in Yemen, Somalia, West Africa etc. ${ }^{14}$

The threat of foreign terrorist fighters has global scope. In 2014, the Security Council of the United Nations was concerned that "foreign terrorist fighters increase the intensity, duration and intractability of conflicts, and also may pose a serious threat to their states of origin, the states they transit and the states to which they travel, as well as states neighbouring the zones of armed conflict in which foreign terrorist fighters are active and that are affected by serious security burdens, and noting that the threat of foreign terrorist fighters may affect all regions and Member States, even those far from

12 LEDUC, Raphaël. 2016. Are returning foreign fighters dangerous? Re-investigating Hegghammer's assessment of the impact of veteran foreign fighters on the operational effectiveness of domestic terrorism. Journal of Military and Strategic Studies. Vol. 17, Issue 1, 83-103.

13 BRZUSZKIEWICZ, Sara. 2018. Radicalisation in Europe after the fall of Islamic State: Trends and risks. European View, Vol. 17, No. 2: 145-154.

14 This categorisation is based mostly on the following publications: FAINBERG, Alisa. 2017. Here We Come: The Evolution of Foreign Fighters' Flow to Syria and Iraq in 2013-2016. Herzlyia: International Institute for Counterterrorism. Available at: https://www.ict.org.il/Article/1954/ the-evolution-of-foreign-fighters\#gsc.tab=0; NESSER, Petter. 2018. Islamist Terrorism in Europe. London: Hurst \& Company; SCHMID, Alex P. 2015. Foreign (Terrorist) Fighters with IS: A European Perspective. Hague: International Centre for Counter-Terrorism. Available at: https://icct.nl/wp-content/uploads/2015/12/ICCT-Schmid-Foreign-Terrorist-Fighters-with-ISA-European-Perspective-December2015.pdf. 
conflict zones, and expressing grave concern that foreign terrorist fighters are using their extremist ideology to promote terrorism. ${ }^{15}$

However, some regions have not been significantly affected by the phenomenon of foreign terrorist fighters and particularly Jihadist FTFs. East Central Europe is one of them. Paradoxically, several individuals from Poland could be considered modern foreign fighters with links to Jihadism; however, they are not terrorists. At least three Poles with anti-communist ideological aims joined the Afghan mujahedeen in the $1980 \mathrm{~s}$ and fought against the Soviets. Only one of them - Lech Zondek - emigrated from Poland during the Afghan war. He was killed in 1985. The other two were earlier emigrants to the West. ${ }^{16}$ Similar cases from other East Central European countries are not known.

FTFs from the Caucasian and Balkan wars in the $1990 \mathrm{~s}$ were not a significant security threat to East Central European countries. Their routes to the conflict area and back led through other territories. A small change can be observed in the $2000 \mathrm{~s}$. Two different cases of men with alleged battle experience or at least training in the Afghan conflict area (related to Al-Qaeda or the Taliban) were connected with East Central Europe; however, this was only from the point of view of transit or short-term residence. In the Czech Republic Oussama Kassir was detained in 2005 and was extradited to the United States two years later. There he was sentenced to life for several acts linked to preparing terrorist activities. ${ }^{17}$ More complicated was the case of the Algerian citizen, Mustafa Labsi, who was detained in Slovakia in 2007 under an Algerian warrant and, after his trial, was extradited to Algeria. The European Court of Human Rights found this extradition unlawful in 2012. ${ }^{18}$

\section{THE CONTEMPORARY SITUATION IN EAST CENTRAL EUROPE}

After the beginning of the Syrian civil war, the phenomenon of Jihadist foreign terrorist fighters started to be a more serious problem in East Central Europe. Of course, Western Europe was hit much more heavily; however, the interdependency of contemporary global and European security meant that the Visegrád countries were also challenged.

15 UNITED NATIONS SECURITY COUNCIL. 2014. Resolution 2178 (2014) adopted by the Security Council at its 7272 nd meeting on 24 September 2014 "Threats to international peace and security caused by terrorist acts". Available at: http://unscr.com/en/resolutions/2178.

16 STANIUL, Michal. 2016. Polscy mudżahedini na wojnie w Afganistanie 1979-1989. WP Online. Available at: https://opinie.wp.pl/polscy-mudzahedini-na-wojnie-w-afganistanie-1979-19896126041611622529 a.

17 US ATTORNEY'S OFFICE. 2009. Swedish Citizen Oussama Kassir Found Guilty of Providing Material Support to al Qaeda. FBI: New York Field Office. Available at: https://archives.fbi.gov/ archives/newyork/press-releases/2009/nyfo051209.htm.

18 EUROPEAN COURT OF HUMAN RIGHTS. 2012. Case of Labsi vs. Slovakia. Application no. 33809/08. Judgement. Available at: https://www.asylumlawdatabase.eu/sites/default/files/ aldfiles/CASE\%20OF\%20LABSI\%20v.\%20SLOVAKIA.pdf. 
From the point of view of these countries, the security threat of the Jihadist FTFs can be divided into three main interconnected issues:

1. Travel of Western European Jihadist foreign fighters and their family members to Syria and Iraq via East Central Europe;

2. Return of Jihadist FTFs and their family members to Western Europe and Eastern Europe $^{19}$ via East Central Europe (of special importance are the terrorist fighters with a clear intention to commit terrorist attacks);

3. Radicalisation, recruitment and travel of home-grown East Central European Jihadists to conflict areas (these people can be divided into converts and members of immigrant Muslim communities) and their return (of special importance are the threats and possible intention to commit terrorist attacks in this area).

Travel by Western Jihadists to the Syrian conflict started in 2011 and law enforcement forces and intelligence services in East Central Europe monitored dozens of travellers. ${ }^{20}$ The issue of returning Jihadist FTFs has become a matter of alarming importance since the start of the migration crisis and the wave of terrorist attacks in Western Europe in 2015-2018. The defeat of the Islamic State and imprisonment of many Jihadist fighters by Kurdish, Syrian and Iraqi forces constitute a new challenge to European security (with, however, only a limited impact on East Central Europe, in contrast to significant Western European concerns). ${ }^{\mathbf{2 1}}$

Returnees to Western Europe with terrorist goals used East Central Europe for traveIling, for a short recuperation and possibly also for logistics. Salah Abdeslam, who was an important member of the IS commando, which committed terror attacks in Paris in November 2015, visited Hungary and Slovakia (where he allegedly stayed for three weeks) in summer 2015. ${ }^{22}$ Another case is linked with Hungary. A 27-year-old Syrian national was detained at Budapest Airport on 30 December 2018. According to the Eurojust, he was „suspected of active involvement in the killing of 20 persons. He was imprisoned

19 Eastern Europe is mentioned due to alleged cases of some Caucasian and Middle Asian Jihadist foreign fighters travelling. According to Europol: "an FTF of Chechen origin with refugee status in Poland was detained in 2017, charged with participation in a foreign military organisation and illegal possession of weapons and ammunition" Europol. 2018. European Union Terrorism Situation \& Trend Report (Te-Sat). The Hague: Europol. Available at: https://www.europol.europa.eu/activities-services/main-reports/ european-union-terrorism-situation-and-trend-report-2018-tesat-2018.

20 Exact data are still classified. The number of these persons can be assessed at around 60 in all V4 countries (around 20 in the Czech Republic). This assessment is based on information from informal interviews conducted by the author of this article with members of security institutions, journalists and academics during international counter-terrorist events. See also sources below.

21 RENARD, Thomas. 2019. Quelle justice pour les djihadistes belges ? Le Vif. Available at: https://www.levif.be/actualite/international/quelle-justice-pour-les-djihadistes-belges/articleopinion-1100939.html?cookie_check=1557831251.

22 CRIME TERROR NEXUS. 2018. The Crime-Terror Nexus in the Czech Republic and Slovakia. Available at: https://crimeterrornexus.com/wp-content/uploads/2018/06/Crime-TerrorNexus-in-the-Czech-Republic-Slovakia_English-Version.pdf. 
for using forged travel documents for both himself and his female partner." ${ }^{\text {23 }}$ This FTF should be extradited to Belgium. In Poland, Moroccan citizen Mourad T. was sentenced by the court of first instance in March 2019 to three years in prison due to the help he gave to the Islamic state. He probably did not serve in Syria or Iraq; however, he cooperated with the Belgian foreign terrorist fighter Abdelhamid Abaaoud, who organised terrorist attacks in Paris in 2015. Mourad T. recruited and helped Jihadist migrants on the Balkan route. ${ }^{24} \mathrm{He}$ married in Poland and travelled to various places, including Hungary and the Czech Republic.

Home-grown radicalised Jihadists who travelled from East Central European countries to the conflict areas can be divided into two main categories. Firstly they are converts from majority traditional nations in East Central Europe ${ }^{25}$ (several cases of individuals from the Polish diaspora in Western European countries can also be found). ${ }^{\mathbf{2 6}}$ Secondly, they are members of Middle Eastern or Caucasian diasporas living in East Central European countries. ${ }^{27}$ Polish experts Ryzsard Machnikowski and Artur Legiec estimate the number of Jihadist FTFs at between 20 and $40 .{ }^{28}$ The Security Information Service of the

23 EUROJUST. 2018. IS terrorist suspect arrested in Hungary, available at: http://www.eurojust. europa.eu/press/PressReleases/Pages/2019/2019-03-22b.aspx.

24 DRABEK, Patryk. 2019. Marokańczyk który mieszkał na Śląsku oskarżony o współpracę z ISIS koniec procesu [WYROK]. Naszemiasto.pl, Available at: http://katowice.naszemiasto.pl/artykul/ marokanczyk-ktory-mieszkal-na-slasku-oskarzony-o-wspolprace,5047715, artgal,t,id,tm.html.

25 The Czech convert Jan Silovský travelled to join IS in Syria in 2016; however, he was detained in Turkey and later sentenced to six years in prison in the Czech Republic. NEJVYŠŠí SOUD ČR. 2018. Rozhodnutí 3 Tdo 1073/2017. ECLI:CZ:NS:2017:3.TDO.1073.2017.1 The Polish convert Jakub Jakus joined IS and was probably killed in 2017 (he used the name Abu Khattab-al Polandi). CEYROWSKI, Artur. 2017. Abu Khattab al-Polandi nie żyje? O śmierć dżihadysty pytamy Marcina Mamonia, autora książki „Wojna braci”. Pressmania.pl. Available at: http://pressmania.pl/abukhattab-al-polandi-nie-zyje-o-smierc-dzihadysty-pytamy-marcina-mamonia-autora-ksiazkiwojna-braci/.

26 Polish expert Jan Wójcik identified Jacek S., who migrated to Germany in 2005, converted in 2014, soon thereafter joined IS and died in 2015 (in a suicide attack in Iraq) and Dawid $t$. (Abu Hanifa) from the Polish diaspora in Norway, who in 2014 allegedly joined Harakat Fajr al-Sham al-Islamiyya (the Islamic Movement Dawn of Syria) and in 2019 was arrested for allegedly preparing a terrorist attack in Poland (judicial proceedings are ongoing). WÓJCIK, Jan. 2019. Returning Foreign Fighters in Central and Eastern Europe. European Eye on Radicalisation. Available at: https://eeradicalization.com/returning-foreign-fighters-in-central-and-easterneurope/.Three other Jihadist foreign fighters had their origin in families of the Polish diaspora in Germany. See MACHNIKOWSKI, Ryszard. - LEGIEĆ, Artur. 2017. The Favored Conflicts of Foreign Fighters From Central Europe. Terrorism Monitor, Vol. 15, No. 10, available at: https:// jamestown.org/program/favored-conflicts-foreign-fighters-central-europe/.

27 A specific "mixed case" is connected with the former Prague imam, of half-Czech halfPalestinian origin, Samer Shehadeh, who arranged the travel of his brother Omar and one Czech female convert to Syria. They married in Syria and joined the Jabhat Fatah al-Sham in 2016. Samer Shehadeh is in custody in the Czech Republic, suspected of having supported terrorism (however, he himself was not an FTF). MINISTERSTVO VNITRA ČR. 2019. Zpráva o projevech extremismu a předsudečné nenávisti na území České republiky v roce 2018. Praha: Ministerstvo vnitra ČR. Available at: https://www.mvcr.cz/clanek/extremismus-vyrocni-zpravyo-extremismu-a-strategie-boje-proti-extremismu.aspx.

28 MACHNIKOWSKI, Ryszard. - LEGIEĆ, Artur. 2017. 
Czech Republic reported about 16 people from the Czech Republic (including two with Czech citizenship) in terrorist organisations in the Middle East. ${ }^{29}$ Between 10 and 15 FTFs from Hungary fought in various Islamist groups in Syria (mostly in al-Qaeda affiliates in Syria; information about the participation of Hungarian fighters in the Islamic state is unavailable). ${ }^{30}$ The Slovak Information Service reported Jihadist foreign terrorist fighters with links to the Slovak Republic, but without specifying an exact number. ${ }^{31}$ Earlier, six Slovak foreign fighters were reported in the documents. ${ }^{32}$

\section{THE CHALLENGES TO LEGAL AND SECURITY SYSTEMS}

Foreign terrorist fighters pose a challenge to international as well as national legal systems. The internationalisation and Europeanisation of criminal law characterise the legal approach taken vis-à-vis this phenomenon in East Central European countries. Political and legal actions were adopted by the United Nations, which placed requirements on member countries. The most important international documents with global impact are Security Council Resolution 2178 (2014), followed by Security Council Resolution 2396 (2017). ${ }^{33}$

The European Union responded to the phenomenon of FTFs with many broadly-focused counter-terrorist measures. ${ }^{34}$ The most important piece of European law is the Directive of the European Parliament and the Council on combating terrorism which replaced Council Framework Decision 2002/475/JHA and amended Council Decision 2005/671/JHA from 23 February 2017. According to the directive, each member state

29 BEZPEČNOSTNÍ INFORMAČNÍ SLUŽBA. 2018. Výroční zpráva Bezpečnostní informační služby za rok 2017. Available at: https://www.bis.cz/public/site/bis.cz/content/vyrocni-zpravy/2017-vzcz.pdf.

30 According to unconfirmed information, some Hungarians also fought in pro-Assad units. PÓCZIK, Szilveszter. 2017. Muslim radicals from the Balkans and Hungary in the Syrian war - A comparative study with focus on social history and security policy. In: PLYWACZEWSKI, Emil W. - GUZIK-MAKARUK, Ewa M. (eds.): Current problems of the penal law and criminology / Aktuelle Probleme des Strafrechts und der Kriminologie. Warsaw: Wydawnictwo C.H. Beck, 708-722.

31 SLOVENSKÁ INFORMAČNÁ SLUŽBA. 2018. Správa o činnosti SIS za rok 2017, http://www.sis.gov. sk/pre-vas/sprava-o-cinnosti-2017.html.

32 GINKEL, Bibi van et al. 2016. The Foreign Fighters Phenomenon in the European Union. Profiles, Threats \& Policies. Hague: International Center for Counter-Terrorism, https://icct. nl/wp-content/uploads/2016/03/ICCT-Report_Foreign-Fighters-Phenomenon-in-the-EU_1April-2016_including-AnnexesLinks.pdf.

33 Improvement of the UN measures is included in the following resolution: UNITED NATIONS SECURITY COUNCIL. 2017. Resolution 2396 (2017) Adopted by the Security Council at its 8148th meeting, on 21 December 2017 "Threats to international peace and security caused by terrorist acts - foreign terrorist fighters", https://undocs.org/en/S/RES/2396(2017).

34 EUROPEAN UNION. 2019. Response to the terrorist threat and recent terrorist attacks in Europe. Available at: https://www.consilium.europa.eu/en/policies/fight-against-terrorism/ foreign-fighters/. 
shall take necessary measures to ensure that travelling to another country for the purpose of committing, or contributing to the commission of, a terrorist offence, for the purpose of the participation in the activities of a terrorist group with knowledge of the fact that such participation will contribute to the criminal activities of such a group or for the purpose of providing or receiving training for terrorism, is punishable as a criminal offence when committed intentionally. ${ }^{35}$ All EU member states (including V4 countries) must transfer the content of the directive into their national criminal law. With the exception of Poland, the rest of the Visegrád countries also ratified the important Additional Protocol to the Council of Europe Convention on the Prevention of Terrorism. ${ }^{\mathbf{3 6}}$

The improvement and Europeanisation of law in the field of foreign fighters has been typical of East Central European countries in recent years. ${ }^{37}$ Changes in national law reflect the EU requirements (criminalisation of activity in a terrorist group, crossing borders with terrorist aims, terrorist training etc.) but the new challenges discussed in Western Europe have not seriously affected the legal norms in V4 countries (for the legal measures for preventing the return of individuals suspected of involvement in terrorism abroad, ${ }^{38}$ stripping of citizenship, ${ }^{39}$ de-radicalisation programmes for returnees, ${ }^{40}$ etc.). This is due to the very limited scope of some problems in comparison with Western European countries (few FTFs, very few FTF family members etc.).

The phenomenon of foreign terrorist fighters demands international police and intelligence cooperation. All Visegrád countries are members of the special Europol network of anti-terrorism contact points "specifically dedicated to the sharing of information

35 EUROPEAN UNION. 2017. Directive of the European Parliament and of the Council on combating terrorism, replacing Council Framework Decision 2002/475/JHA and amending Council Decision 2005/671/JHA.

36 COUNCIL OF EUROPE. 2019. Chart of signatures and ratifications of Treaty 217. Additional Protocol to the Council of Europe Convention on the Prevention of Terrorism Status as of 17/05/2019. Available at: https://www.coe.int/en/web/conventions/full-list/-/conventions/ treaty/217/signatures?p_auth=wdVkbo0R.

37 The Czech Act No. 287/2018 Coll. amended the Criminal Code No. 90/2009 Coll. in the sense of the above-mentioned directive. A similar Slovak law is Act No. 161/2018 Coll., which amended the Slovak Criminal Code No. 300/2005 Coll. New criminal offences were also added to the Hungarian and Polish criminal codes. MICHALSKA-WARIAS, Aneta. 2018. New Terrorist Offences in Polish Criminal Law. Annales UMCS, Vol. 65, No. 1, 103-114.

38 This issue is connected also with the problem of (non-)intervention in cases of prosecution and sentencing (including the death penalty) in Iraq or Syria of the Islamic state fighters with EU citizenships. SCHERRE, Amandine - ISAKSSON, Cecilia - RAGAZZI, Francesco - WALMSLEY, Josh. 2018. The return of foreign fighters to EU soil. Ex-post Evaluation. Brussels. European Parliamentary Research Service. Available at: http://www.europarl.europa.eu/RegData/ etudes/STUD/2018/621811/EPRS_STU(2018)621811_EN.pdf.

39 ROITHMAIER, Kilian. 2019. Germany and its Returning Foreign Terrorist Fighters: New Loss of Citizenship Law and the Broader German Repatriation Landscape. ICCT. Available at: https://icct. $\mathrm{nl} /$ publication/germany-and-its-returning-foreign-terrorist-fighters-new-loss-of-citizenshiplaw-and-the-broader-german-repatriation-landscape/.

40 HASSAN, Ahmad Saiful Rijal. 2018. Deradicalising Returning Foreign Fighters: Lessons from Denmark. RSiS. Available at: https://www.rsis.edu.sg/rsis-publication/icpvtr/deradicalisingreturning-foreign-fighters-lessons-from-denmark/\#.XN76UPZuldU. 
concerning the FF" (it was established in 2014). ${ }^{41}$ The phenomenon of foreign fighters (including Jihadist foreign fighters) was one of the main topics of the meeting of the "V4+2 ${ }^{42}$ counter extremist group" in $2015 .{ }^{43}$ Unfortunately, this form of cooperation has not developed further in recent years. International counter-Jihadist cooperation is able to overcome the tensions in other fields of international relations, as the case of Polish-Russian collaboration against the Chechen foreign fighter Azamat Bajdujew shows. He fought in IS, was arrested in Poland and extradited to Russia in $2018 .{ }^{44}$

Furthermore, FTFs pose a specific challenge to national security systems and inter-agency cooperation in the V4 countries. FTFs are an issue that affects both the internal and external security of the state, and both military and non-military security. It means that both civil (police, security and intelligence agencies etc.) and military (intelligence, special forces etc.) institutions are forced to cooperate in this field. In countries with a strict division of powers between law enforcement agencies and intelligence services (in V4 mostly the Czech Republic and Slovakia) the use of intelligence agencies' knowledge during trials of FTFs remains an unsolved challenge for the criminal procedural law. ${ }^{45}$

\section{CONCLUSION}

Jihadist foreign terrorist fighters are considered a significant threat by the global security community as well as by regional European security structures. East Central European countries are not as seriously and directly affected by this problem as Western European or Balkan countries are. However, due to the interconnection and transnationalisation of contemporary security policies, they do take these problems seriously. Several tens of fighters from East Central European countries have joined Jihadist groups in the Middle East during the past decade.

Returnees from these countries have not been directly involved in the preparation of terrorist attacks (as far as is known) and there is no evidence of these people serving in the roles of recruiters or veterans (one killed Polish Jihadist can be labelled as a martyr).

\footnotetext{
41 GINKEL et al.

42 Visegrád countries + Germany and Austria.

43 VLÁDA ČR. 2015. Program českého předsednictví ve Visegrádské skupině v letech 2015-2016. Ministerstvo zahraničních věcí ČR. Available at: https://www.vlada.cz/assets/evropskezalezitosti/visegradska-skupina/Program-a-priority-CZ-V4-PRES.pdf.

44 MIEŚNIK, Magda. 2018. "Deportowany Czeczen walczył w szeregach Państwa Islamskiego". Polska ujawnia powody deportacji. WP. Available at: https://wiadomosci.wp.pl/deportowanyczeczen-walczyl-w-szeregach-panstwa-islamskiego-polska-ujawnia-powody-deportacji$6301980027611265 a$.

45 Of course, this issue is connected not just with the FTFs, but with a broader spectrum of security threats. POKORNÝ, Ladislav. 2018. Jest zvažovati důkazní použití odposlechu pořizeného zpravodajskou službou? In KALVODOVÁ, Věra, Marek FRYŠTÁK a Jan PROVAZNík (eds.). Trestní právo /stále/ v pohybu: pocta Vladimíru Kratochvílovi. Brno: Masarykova univerzita, 281-294.
} 
However, FTFs from Western Europe responsible for terrorist attacks travelled through the Visegrád countries and some of them used that territory for longer visits. The security forces of the Czech Republic, Slovakia, Hungary and Poland have successfully detained and/or monitored many FTFs; however, only a few cases have been decided by the courts and some suspects were not detected in time.

A set of new EU norms have been adopted. It is important to evaluate the efficiency of these norms and their use by national police and judicial bodies. Findings should be discussed at sub-regional as well as European level. Inter-agency cooperation and the capability to share and together to assess threats are requested at the national level. A re-start of $\mathrm{V} 4+2$ cooperation with a broader spectrum of participants (including in the military sphere) should help to counter Jihadist FTFs. Strong Euro-Atlantic cooperation and the involvement of credible partners in various parts of the world (mostly in sharing information, efficient law enforcement and efficient military combat against the terrorist structures in conflict areas) will remain the most important tasks for the future.

This paper was written under the research project OPTIZ "Optimization of Intelligence Activities and Intelligence Institutions in the Changing Environment" (OPTIZ9070204510), funded by the Ministry of Defence of the Czech Republic ("Development of the Armed Forces of the Czech Republic" defence research programme).

Author: $\quad$ prof. Miroslav Mareš, PhD., born in 1974. He is the guarantor of security and strategic studies at the Department of Political Science of the Faculty of Social Studies of Masaryk University in Brno. He focuses on the research of extremism and terrorism in the Central Europe. He is a member of the European network of experts in matters of terrorism (EENET). He has worked with the OSCE and participated in the counter-extremism and the counter-terrorism activities of the European Union. He is an author or co-author of more than two hundred publications (among other with Astrid Bötticher they wrote the book Theorien, Extremism - Konzepte, Restoring, issued in 2012, in Munich).

How to cite: MAREŠ Miroslav. Jihadist Foreign Terrorist Fighters: Contemporary Threats and Challenges in East Central Europe. Vojenské rozhledy. 2019, 28 (3), 003-015. ISSN 1210-3292 (print), 2336-2995 (on-line). Available at: www. vojenskerozhledy.cz 


\section{Religious Extremism as a Cause of Armed Conflicts: Indicators and Early Warning Systems}

\section{Náboženský extremismus jako příčina ozbrojených konfliktů: indikátory a systémy včasného varování}

\section{Josef Kraus}

Abstract: The main topic and focus of this article is to identify the most relevant indicators of the rise of religious extremism as an important cause of armed conflicts. A religiously motivated conflict is a relevant topic in modern security studies and research. Conflict prevention using the early-warning indicators identified in this article might be interesting for the security expert community. In the article chosen methodology is available with the recommendation to following research in the examined field.

Abstrakt: Hlavním cílem tohoto textu je identifikovat nejčastěji využíváné a nejrelevantnější indikátory vzestupu náboženského extremismu ve společnosti jakožto důležité př́činy ozbrojených konfliktů. Nábožensky motitovaný konflikt je důležitým tématem současného bezpečnostního výzkumu. Jeho prevence za použití systému včasného varování opřeného právě o dílčí indikátory je tak pro bezpečnostní komunitu velice zajímavá. Tento článek představuje vybrané metodiky a doporučení pro další navazující výzkum celé problematiky.

Key words: $\quad$ Early Warning System; Extremism; Methodology; Prediction; Religious Conflict; Security Indicators.

Klíčová slova: Systém včasného varování; extrémismus; metodologie; predikce; náboženský konflikt; bezpečnostní indikátory. 


\section{INTRODUCTION}

Religion plays a pivotal role in the lives of many, with over $70 \%$ of the world population identifying as members of a religious community. Religion influences the values, beliefs and behaviours of groups and individuals both within the humanitarian sector and within its operating environment. Opinions, values, understanding and actions can influence the risk environment " - and the armed conflict as well. ${ }^{1}$ The conflict, in general, can be defined as „an expression of the heterogeneity of interests, values and beliefs that arise as new formations generated by social change come up against inherited constraints." 2 Religion (or faith as defined) is one of the main sources of conflict between and among different religious groups. Moreover, the ethnic dimension often plays the same role in combination with religion. It is a matter of identity and narratives for both individuals and communities. Perceptions of prejudice, victimhood, and discrimination are central in the dynamics of structural, physical and cultural violence. ${ }^{3}$ Finding a purely religious conflict is nothing easy. Usually, there are plenty of reasons provoking violence and many other dimensions of conflict than religion. So, to define a religious conflict, there is a need to view it as a complex phenomenon that engages a combination of contested domains, including power, personality, space or place, and group identity. Also, a distinction should also be drawn between the root cause/s of the religious conflict (what is contested) and how the conflict is discursively or narratively framed. There is also the need to distinguish between conflict and competition. Very simple, we can say a conflict is religious when a conflict in which religion is also involved occurs. We can then avoid the questions when a conflict is religious and when is it political/ethnic since the definition allows the conflict can be both. If we focus on actors or agents of religious conflict, there have to be two or more groups that derive from identifiably separate religions, separate factions within the same religion (sectarianism), the same faction within a religion, and secular authority. ${ }^{4}$

Religion can be just one dimension or cause of armed conflict, but when and how we can identify or predict it is becoming a threat for regional or state security? The process of radicalization can provide to an analyst a movement or social tendency to follow in society. Radicalization is the process by which individuals are introduced to an overtly ideological message and belief system that encourages movement from moderate, mainstream beliefs toward extreme views. Radical thinking is not a crime in itself. Sympathizing

1 European Interagency Security Forum. 2014. Security Risk Management and Religion: Faith and Secularism in Humanitarian Assistance, Insecurity Insight, pp. 2, Available at: http://www. insecurityinsight.org/aidindanger/wp-content/uploads/2014/08/EISF_Security-RiskManagement-and-Religion_-August-2014.pdf

2 Ramsbotham, O., Woodhouse, T. and Miall, H. 2005. Contemporary Conflict Resolution. 2nd edn. Cambridge and Malden: Polity, pp. 17

3 British Academy. 2015. The Role of Religion in Conflict and Peacebuilding, London. ISBN 978-0-85672618-7. p. 9.

4 MAYER, Wendy. 2013. Religious Conflict from Early Christianity to the Rise of Islam. Arbeiten Zur Kirchengeschichte: De Gruyter. ISBN 9783110291780 pp. 2-4 
with radical thinking does not necessarily lead to violence or terrorist action. However, radical thinking becomes a threat to national security when it leads an individual to espouse or engage in violence as a means of achieving political, ideological or religious goals. ${ }^{5}$ Following the religious radicalization process can be a crucial part of any kind of warning system focusing on religious extremism as a threat or a cause of armed conflict. The main goal of this article is to explain and describe the functions of different kinds of early warning systems and conditions for their application towards chosen society in identifying risks of armed conflict based on religious extremism. Also, another goal of this article is to identify the most relevant indicators of the rise of religious extremism as an important cause of armed conflicts in general. Further case studies can verify this approach and propriety of chosen indicators. This contribution is limited only on providing the framework for future work of analysts and experts on state or regional security.

\section{INDICATORS AND THE EARLY WARNING SYSTEMS}

Indicators or the early warning signals based on the developed early warning systems (EWS) are often used in the spheres of intelligence, predictive analysis or prevention. Identification of those and their following can help the state authority, international organisations, NGOs and expert individuals to be in touch with an examined object affected society, a regional security complex, a state etc. Especially in the case of conflict prevention, EWS and radicalisation indicators are widely used.

There are many layers or levels for examining and identifying proper indicator leading to the detailed observation of the chosen topic. Also, from the perspective of methodology, many different approaches can be used. Different tools provide different outcomes and can be used for different kinds of research and analysis. To predict or to monitor a violent conflict, early warning systems generate indicators in a variety of ways. Hagmeyer-Gaverus and Weissmann ${ }^{6}$ identify three main methods or models used to monitor and forecast developments in countries and crisis regions:

1. The database model based on statistical indicators, often time series data, provided on an annual basis by international organisations such as the World Bank and the United Nations.

2. Models using expert knowledge to forecast trends. The expert model bases its information on questionnaires and interviews, thus creating a separate set of indicators. Expert models usually obtain information from a wide range of informants in a regular, quick and standardised way, frequently used by NGOs, think-tanks and other.

5 Royal Canadian Mounted Police. Terrorism and Violent Extremism Awareness Guide, p.6, Available at: http://www.rcmp-grc.gc.ca/en/terrorism-and-violent-extremism-awareness-guide

6 HAGMEYER-GAVERUS, Gerd and Mikael WEISSMANN. 2003. Early Warning Indicators for Preventive Policy - a new approach in Early Warning research. SIPRI, Working Paper, Available at: https://www. diva-portal.org/smash/get/diva2:967529/FULLTEXT01.pdf 
3. News-wire monitoring/analysis systems that assess the risk of conflict through systematic machine coded coverage of news services such as Reuters.

This mainly quantitative approach can be very useful, especially with the existence of fulfilled database or advanced predictive models. Except for the method no. 2, there is just very limited space for regional experts to influence the outcome of an analysis. It is very much critical for the other two methods to depend on the relevant data and complete datasets for threat evaluation. The methods are very vulnerable towards data put into the process of its evaluation. Without combining it with experts supervision (or method no. 2), there might occur a problem with incorrect interpretation and evaluation of pure statistics. That is why the combination of quantitative and qualitative approaches are widely used for conflict prevention and conflict prediction systems or EWS in general.

SIPRI, the Stockholm International Peace Research Institute - the independent resource on global Security, ${ }^{7}$ works with two approaches (database and expert models) together combined increasing the accuracy of forecasts by including both short- and long-term data in the analysis. Statistical data are perfect for long-term predictions while for an extended forecasting model; however, short-term development data are essential. Such data cannot be obtained from country statistics, but only through observation of daily political, economic, and other events. This method is used for selecting and short-term indicators that are best suited to measure changes in areas such as political and economic performance, ethnic or religious issues, and human rights.

On the other hand, the purely quantitative approach is represented by a Global Model for Forecasting Political Instability (known as PITF) funded by the Central Intelligence Agency and hosted by the Center for Global Policy at George Mason University. ${ }^{8}$ The method is based on identification over 100 problem cases for the last half a century that had led to state failure, phenomenons like ethnic conflicts, regime changes, genocides etc. It can be a good tool for further analysis and definition of early warning signals (or indicators), but it is not a self-sufficient method for generating full-scale EWS. That is why majority of the projects, such as IGAD's Conflict Early Warning and Response Mechanism (CEWARM ${ }^{9}$ ) or Network for Ethnic Monitoring and Early Warning (EAWARN ${ }^{10}$ ) are based on a combination of both approaches adapted to local conditions or examined cases and regions.

Oliver Walton ${ }^{11}$ from the Governance and Social Development Resource Centre provides a list of general indicators for potential risks to security based on his research and literature retrieval. The list is divided into nine categories:

- Justice and human rights

7 Ibid.

8 See http://scip.gmu.edu/a-global-model-for-forecasting-political-instability/

9 See https://cewarn.org/index.php/about-cewarn

10 See http://www.incore.ulst.ac.uk/services/cds/metadata/eawarn.html

11 WALTON, Oliver. 2011. Helpdesk Research Report: Early Warning Indicators of violent conflict, Governance and Social Development Resource Centre, Avalable at: http://www.gsdrc.org/docs/ open/hd777.pdf 
- Socio-cultural factors

- Internal security setting

- Geopolitical setting

- Military and security

- Environment and resource management

- Governance and Political Stability

- Socio-economic factors

- Regional and Country-Specific factors

From the perspective of religious extremism, some are more and some less relevant. There is a need to distinguished those according to local conditions. For instance, the military and security category can be irrelevant for homogenous societies without a history of ethnic-religious conflict on its territory, while for those recently affected by civil war, uprising or any kind of armed violence with religious dimension this category can be very much relevant and risky.

Walton also works with a division of conflict early warning indicators into five categories with basic characteristics:

- Demographic (Sudden demographic changes and displacement/movements of people, increasing ,territoriality“ of groups/peoples)

- Economic (Short-term and long-term changes in the economic performance of a country or a region, increase in poverty or inequality, the rise of the unemployment rate, economic shocks or financial crises)

- Policy-Related (Deliberate acts of governments against a specific group or region, destruction or desecration of religious sites, active discrimination or legislation favouring one group over another, potentially destabilising referendums or elections, government "clamp-downs")

- Public Opinion or "Social Factors“ (a rise in „societal“ intolerance and prejudice, an increase in numbers of demonstrations or rallies)

- External (intervention or support on behalf of one of the parties/groups by an external actor, - diffusion“ or "contagion“ of ideologies or conflicts in neighbouring regions, an influx of refugees from a conflict in a neighbouring country).

Naturally, these categories need more operationalisation before being used for database creation. In that case, there would be a need to implement a security category of any kind in it. Can be part of the policy related or the social factors categories with special focus on the level of violent or politically motivated criminality, for instance. On the other hand, the external category seems to be very wide, broad and general in Walton's conceptualization. In many current conflicts, interference from abroad plays a crucial role in conflict escalation. 
The Institute for Safety, Security and Crisis Management ${ }^{12}$ has brought a detailed framework for radicalization and recruitment identification and counter-radicalization strategy combining quantitative and qualitative techniques. Its definition of man categories are very much similar to Walton's but bringing three different levels or layers for radicalisation identification:

1. External level including political, economic and cultural causes of radicalisation,

2. Social level with relative deprivation, social identification and network dynamics,

3. Individual level and its psychological characteristics, personal experience and rationality;

The special focus of this concept is put on recruitment and trigger events. It also provides the diversification of approaches according to the level of the causal factors. The first and the second level can be more examined with quantitative techniques, while the third layer - the individual one - is mainly based on a quantitative and multi-disciplinary approach. But still, there is a noticeable connection and interaction among those three levels, or at least between two different layers. But also some do not affect others at all. External factors manifest themselves independently of the individual. They shape and constrain people's environment, but individuals have an only minor influence on their environment. External factors do not have a direct effect on individual behaviour. A complex interaction between factors at the various levels is likely to be crucial for the intensity of the readiness for radicalisation. Social factors play an important intervening role in the relation between external factors and radicalisation. For example, stigmatisation of Islam in the media, an external cultural factor, is likely to impose a stronger radicalising force on Muslims than on non-Muslims. At the individual level, psychological characteristics, personal experiences and rationality influence how people respond to their social and external environment.

All the factors mentioned above and categories need detailed operationalisation to be usable for both quantitative and qualitative research. But, the identification of the indicators is more need for the quantitative approach than the qualitative one. Plus, it needs permanent monitoring of those for capturing the threat of rising radicalisation of society and predicting threats. The prediction and forecasting of risks and threats is also something worth mentioning in the case of EWI. Segell ${ }^{13}$ speaks about three broad types of methodologies for predicting and forecasting acts or events that have not been identified: 1) trends and patterns, 2) frequency, and 3) probability. All three have to gather data within a specific context to be passed on for an actionable operation. This approach is very much used by intelligence services for developing and establishing warning systems world wide.

12 Institute for Safety, Security and Crisis Management, 2008. Radicalisation, Recruitment and the EU Counter-radicalisation Strategy, Transnational Terrorism, Security and the Rule of Law, Available at: http://www.gdr-elsj.eu/wp-content/uploads/2014/02/doc2-WP4-Del-7.pdf

13 SEGELL, Glen M., 2005. Intelligence Methodologies Applicable to the Madrid Train Bombings, 2004, International Journal of Intelligence and Counter Intelligence, 18, 221-238pp. 


\section{THE RADICALISATION OF AN INDIVIDUAL}

There is another approach in preventing religious radicalisation as conflict prevention. Focusing on an individual instead of society can bring a completely different set of indicators or warning signals. Allison Smith ${ }^{14}$ identifies several potential risk factors for individuals attempting to engage in terrorism (group-based or lone-wolf). Although the factors are highly connected to armed violence and terrorism itself and not to radicalism in general, it is still valuable for the process of radicalisation of an individual.

- Having a History of Criminal Violence

- Having a Criminal History

- Having Been Involved With a Gang or Delinquent Peers

- Having a Terrorist Friend

- Being a Member of an Extremist Group for an Extended Period

- Having a Deep Commitment to an Extremist Ideology

- Having Psychological Issues

- Being Unemployed

- Having a Sporadic Work History

- Having Less Education

- Having a Lower Social Economic Status

- Failing to Achieve One's Aspirations

- Having Trouble in Romantic Relationships

- Having Trouble in Platonic Relationships

- Having Been Abused as an Adult

- Being Distant From One's Family

Many of those are based on socio-economic and psychological problems causing a frustration of an individual. Especially for those territories affected by armed conflict, having military experience ${ }^{15}$ is also identified as a potential risk factor leading to violence.

The Royal Canadian Mounted Police provides another set of indicators for violent radicalisation from the criminology perspective. ${ }^{16}$

- Significant changes of interests;

- Breaking relational ties, social isolation, change in peer groups and activities;

- Change in the way of thinking and interacting with others;

- Rejection of the State (politics and social values);

- Participating in radical activities or demonstrations and using extremist language;

14 SMITH, Allison. 2018. Risk Factors and Indicators Associated With Radicalization to Terrorism in the United States: What Research Sponsored by the National Institute of Justice Tells Us, National Institute of Justice, Available at: https://www.ncjrs.gov/pdffiles1/nij/251789.pdf

15 For the purpose of Smith's reasearch, military experience in US reality means mainly the military service in general. But, in conflict areas any experience of participation on armed conflict in general might be considered being a risk factor.

16 Ref. 12 
- Attending private meetings;

- Overconsumption of hate and violent propaganda images and videos on the Internet;

- Possession of propaganda material promoting violence;

- Segregation and antagonism („Us against Them“);

- Adhering to hatred and violence;

- Glorification of violence or sacrifice;

- Perpetration of minor crimes motivated by the rejection of governments and society;

- Change in appearance and dress style;

- Use of new names or pseudonyms in social media and personal environment;

These two sets of factors are very much similar to each other accenting psychological and social indicators, just the very close surrounding of an individual can notice. From the perspective on a general analysis of the environment (regional, state-level) affected by the threat of radicalisation and religious violence, it is impossible to observe and examine population in general according to individual factors. On the other hand, those can be very much helpful for local authorities to identify risky individuals and their possible networking providing broader statistics at the national level.

\section{THE USE OF INDICATORS AND EWS IN RELIGIOUS CONFLICT PREVENTION}

One of the methods used for predictions and identification of the threat of religious extremism in society is situation analysis. Gerrie ter Har and Stephen Ellis ${ }^{17}$ break religion down into four components that should be observed, monitored and analysed:

- Religious ideas: The perceptions of the universe, the world, life, nature, evil, the sacred, up to and including the virtues and values that guide actions.

- Religious practices: The actions, customs, places and objects that link perceptible reality with imperceptible reality.

- Religious organisations: The religious movements, communities and organisations, their leaders and the networks in which they cooperate.

- Religious experiences: People's experiences in relation to the transcendent. The transcendent here is a generic term for the ultimate, the divine, spirits, ancestors and gods. Religious experience can be at the root of transformations, both individually and collectively.

17 Gerrie ter Haar \& Stephen Ellis, "The role of religion in development. Towards a new relationship between the European Union and Africa", European journal of development research, 18, no. 3 (2006): 351-367. 
Based on the obtained data, the threat analysis has to follow. The crucial question is whether, and how, religion can impact on the threat itself and on the vulnerability of an agency or individual. ${ }^{\mathbf{1 8}}$ The analysis is based on three analyst sub-questions related to each other in the triangle of threat identification - diagram 1.

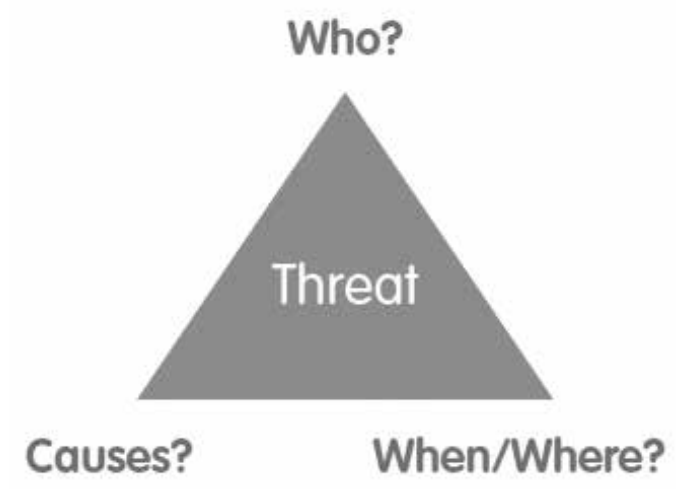

Diagram 1: Triangle of threat identification

The question "who" is related to a perpetrator of the threat and also to the potential or real victims. There is scope to examine whether religion is a motivating factor for the perpetrators or if it influences the selection of victims. "When and where" deals with the time and space - Is the threat more likely to occur in certain areas? Is there a link between threat and the religious composition of the population in that area? Are there particular locations of operation where threats are most likely to occur? And the last but not least question asking for "causes“, roots and drivers of identified threats. In areas of religious tension, religion can be one of these drivers or underlying causes.

The problem again is how to operationalise terms and layers mentioned above and put them into a proper pattern to be followed. It can provide a good framework for going deeper into the analysis of the examined phenomenon.

\section{CONCLUSION}

This article provides the basic background for the early warning system creation for further case studies, systematic intelligence analysis or conflict prevention. There are two main approaches to EWS creation and indicators identification - a quantitative one and a qualitative one. Some systems work with quantitative approach only providing warning indicators and redlines based on pure statistics. The problem is, there is just

18 lbid. 
a small space for regional experts to influence the outcome, while it is very much needed during the process of threat evaluation. The pure qualitative approach can miss the important macro view over the state or regional security. Especially, in the economy and demography, the statistics can provide different and much wider perspective. So, only the combination of two approaches seems to be ideal in creating the EWS in general.

Focusing on the topic of religious extremism as a cause of conflict and threat to national or regional security, mainly the process of society radicalisation has to be analysed. Religion itself is a very amorphous issue to be examined; that is why the religious radicalisation is difficult to handle. The theories of political radicalisation can help to prepare the proper framework for it. There are three layer or levels at which the process should be analysed or observed by a multi-disciplinary approach. Individual level focused on personal issues connected to psychology and sociology, social level dealing with the society as a whole, its tendencies, development and even statistics, and last but not least the external level including political, economic and cultural causes of radicalisation and its spill-over effect from abroad. This approach needs a continual observation of the set of indicator not only by statistics but also by regional experts on politics, sociology and psychology.

It is very difficult to bring a general scheme and system applicable to every region and society potentially facing the threat of religious extremism causing armed conflict. Local conditions should be taken into account, otherwise risking too much general and dysfunctional EWS. Only case studies with the general framework and local mutations can provide relevant outcomes and suitable system for conflict prevention of any kind, but religious dimension and cause needs special attention due to amorphous essence of the phenomenon.

This paper was elaborated as a part of the research project SIVARBAL (Proposal of the system of indicators of early warning for possible crisis situations in Balkan), funded by the Defence research of the Ministry of Defence of the Czech Republic.

Author: Josef Kraus, Ph.D., born in 1985. He graduated from the bachelor's, master's and doctoral studies in political science at the Faculty of Social Studies, Masaryk University. He still acts as an assistant professor at the Department of Security and Strategic Studies. He is also a scientific researcher at the International Institute of Political Science. At the same time he is a member of the editorial board of the Czech Military Review journal. He deals with the security problems of the Middle East region, with a focus on Islamic Republic of Iran and state terrorism research.

How to cite: KRAUS Josef. Religious Extremism as a Cause of Armed Conflicts: Indicators and Early Warning Systems. Vojenské rozhledy. 2019, 28 (3), 016-025. ISSN 1210-3292 (print), 2336-2995 (on-line). Available at: www.vojenskerozhledy.cz 


\section{Role neokolonialismu ve vývoji bezpečnostní situace v Afghánistánu}

\section{The role of neo-colonialism in the Evolution of Security Situation in Afghanistan}

\section{Martin Havlík}

Abstrakt: Hlavním cílem toho článku je pojednat o roli postkoloniální teorie neokolonialismu ve vývoji bezpečnostní situace v Afghánistánu. Úvodní část je věnována vymezení postkoloniálního přístupu. Na tuto část navazuje definiční přehled neokolonialismu, jakožto moderní formy pokračování kolonialismu. $V$ další části je pozornost zaměřena na roli samotného neokolonialismu v Afghánistánu, a to ve vztahu $\mathrm{k}$ působení a zájmům USA. Dále jsou v článku vymezeny hlavní dopady na bezpečnostní situaci a také výsledky deformace sil regionálních aktérů (Pákistánu a Indie) v Afghánistánu v důsledku angažovanosti USA v oblasti. Závěrečná část shrnuje podstatné informace v kontextu teoretických požadavků a znaků teorie neokolonialismu ve vztahu k aktivitám USA a dalších státních aktérů v Afghánistánu i celém regionu.

Abstract: The main goal of this article is to depict the role of postcolonial theory of neo-colonialism in the development of the security situation in Afghanistan. The introductory part is devoted to defining the postcolonial approach. This part is followed by a definition of neo-colonialism as a modern form of continuation of colonialism. The next part is focused on the role of neo-colonialism itself in Afghanistan, in relation to the influence and interests of the USA. In addition, the paper outlines the main security implications as well as the distortions of Afghanistan's regional actors (Pakistan and India) as a result of US engagement in the region. The final part summarizes the essential information in the context of the theoretical requirements and signs of neo-colonialism in relation to the activities of the US and other state actors in Afghanistan and the region.

Klíčová slova: Afghánistán; bezpečnostní prostředí; Indie; kolonialismus; mezinárodní vztahy; neokolonialismu; Pákistán.

Key words: Afghanistan; Security Environment; India; Colonialism; International Relationships; Neo-colonialism; Pakistan. 


\section{ÚVOD}

Důležitou roli v hodnocení či ve vývoji bezpečnostní situaci Afghánistánu vždy hrála globální i regionální geopolitika, která představovala složitou sít vzájemných interakcí mezi velmi rozdílnými regionálními aktéry s různým postavením (na regionálním i globálním politickém poli). Centrem takových interakcí se opakovaně stával Afghánistán, který má odlišné vztahy se svými sousedy i dalšími vlivnými státními aktéry. Vývoj politické a zejména bezpečnostní situace je významně ovlivněn především Spojenými státy americkými (USA), Ruskou federací (RF), Íránem a Pákistánem, dále pak Čínskou lidovou republikou (ČLR) a Indií. Vztahy všech zainteresovaných státních aktérů v Afghánistánu zintenzívněly jak po stažení vojsk Sovětského svazu z Afghánistánu v roce 1989, tak dále po spojenecké intervenci v roce 2001 . $^{1}$ Je nutné brát v potaz, že ke vzájemnému rozvoji vztahů mezi významnými aktéry v Afghánistánu ve všech svých konotacích (negativních či pozitivních) dochází kontinuálně do dnešní doby a s ohledem na historické souvislosti k tomu bude s velkou pravděpodobností docházet i v budoucnu.

Význam samotného Afghánistánu a stability jeho bezpečnostní situace je podtržen a umocněn v regionálním pohledu jeho strategickou polohou, která se nachází mezi třemi muslimskými postsovětskými republikami Turkmenistánem, Uzbekistánem a Tádžikistánem, dále pak Pákistánem a Íránem. Mimo to dále Afghánistán svou severovýchodní provincií Badachšán sousedí také s ČLR. Každý z těchto jmenovaných státních aktérů má nepopiratelně zejména své ekonomické zájmy také v samotném Afghánistánu. Významným regionálním státním aktérem s dopadem na vývoj bezpečnostní situace je zejména Pákistán, který je reprezentován poměrně velkou a aktivní armádou s výraznou rozhodovací pravomocí a jaderným arzenálem. Hlavními zájmy pákistánské armády (včetně velmi mocné zpravodajské služby) je působení vůči dlouhodobé a nejvýznamnější hrozbě $\checkmark$ podobě největšího rivala - Indie. Aktuální pozice Pákistánu na mezinárodním poli je posílena jeho spojenectvím s USA, které s tímto významným regionálním aktérem úzce spolupracují, a to nejen v obchodní oblasti. Vliv Indie na bezpečnostní situaci v Afghánistánu Ize obecně charakterizovat jako nepřímý s primárním záměrem podporovat veškeré proti-pákistánské aktivity.

Mezinárodněpolitický význam Afghánistánu vzrostl zejména v 19. století, kdy se ocitl Afghánistán na křižovatce britsko-ruského soupeření. Zájem Ruska (zejména v období Sovětského svazu) vedl přes Afghánistán z toho důvodu, že se nachází na trase směřující dále na jih, směrem k Íránu, Pákistánu (provincie Balúčistán) a dále pak k Perskému či Ománskému zálivu, k Arabskému moři a $\mathrm{k}$ Indickému oceánu. V př́padě zájmů Velké Británie se Afghánistán nacházel na trase dalšího pronikání z Indie směrem k Číně a Tibetu. Afghánistán Ize proto považovat za území, kterému se nelze vyhnout při postupu směrem do geopoliticky významných oblastí Asie. Tento strategicky důležitý význam

1 HYNEK, Nik, EICHLER, Jan a MAJERNÍK, L'ubomír. Konflikt a obnova v Afghánistánu: kontext, prostředí a zájmy. Praha: Ústav mezinárodních vztahů, 2012. ISBN 978-80-87558-06-5. Str. 11. 
Afghánistánu zůstal zachována i v moderních dějinách (od skončení druhé světové války až do současnosti). ${ }^{2}$

Od konce 2. světové války a pádu britské i francouzské koloniální nadvlády, došlo k velmi významným posunům zejména v oblasti světové ekonomiky spojené s poměrně masivními sociálními a politickými změnami (nejen vyhlášení nezávislosti mnoha států v rámci procesu dekolonizace). Avizované období od druhé poloviny 20. století bylo poměrně významné pro rozvoj postkoloniálních teorií v oblasti mezinárodních vztahů, které se věnovaly širokému spektru vzájemných interakcí zejména státních aktérů a pohledům západní společnosti na vývoj v muslimském světě. $V$ této souvislosti se postkoloniální přístup mnoha odborníků snažil analyzovat především úlohu, postavení a vliv mocností na další státní aktéry, a to zejména v oblasti Latinské Ameriky, Afriky ${ }^{3},{ }^{4}$ či Asie. ${ }^{5}$ Akcent postkoloniálních teoretiků a odborníků byl orientovaný primárně na ekonomickou a politickou dimenzi a související nástroje moci zaměřené na prosazování vlastních zájmů. Z existujícího spektra postkoloniálních teorií byl proto na tento článek v kontextu ekonomicko-politického pohledu vybrán a aplikován přistup a teorie neokolonialismu. Tento konkrétní postkoloniální teoretický rámec označovaný jako neokolonialismus bude v článku použit jako nosný koncept. Je zřejmé, že na vybrané regionální státní aktéry by šly aplikovat také jiné konkrétní postkoloniální teorie, nicméně s ohledem na aktuální ekonomicko-politické dopady a vlivy je nejvíce relevantní právě teorie neokolonialismu.

\section{VYMEZENÍ NEOKOLONIALISMU}

Obecná teorie neokolonialismu ve své zásadě předpokládá existenci silných přímých i nepřímých ekonomických vazeb mezi ekonomicky silnými mocnostmi a ekonomicky slabšími státy. S ohledem na existenci vzájemných ekonomických vazeb je proto evidentní, že chování politických elit ekonomicky slabších a závislých států je více či méně podřízeno požadavkům mocností. Ekonomický rozměr teorie neokolonialismu zastupuje v tomto postkoloiálním konceptu nejvýznamnější dimenzi a ostatní jsou v určité míře potlačeny (politická, vojenská, sociální apod.).

Jak bylo uvedeno výše, neokolonialismus se zpravidla orientuje spíše na politicko-ekonomický kontext na rozdíl například od kontextu politicko-kulturního. Toto potvrzuje také ACHARYA a BUZAN ve své publikaci Non-Western International Relations Theory

2 Ibid. Str. 15.

3 ZHENG, Liang. Neo-colonialism, ideology or just business? China's perception of Africa. Global Media and Communication, 271-276. [online] 2010. [cit. 2019-03-28] Dostupné z: https://doi.org/10.1177/1742766510384964

4 ANTWI-BOATENG, Osman. New World Order Neo-Colonialism: A Contextual Comparison of Contemporary China and European Colonization in Africa. Journal of Pan African Studies 10. 2. [online] 2017 [cit. 2019 03-20] Dostupné z http://bit.do/eQ4v8

5 NAGESH, Rao. 'Neocolonialism' or 'Globalization'?: Postcolonial Theory and the Demands of Political Economy. Brown Uviversity - Interdisciplinary Literary Studies, vol. 1, no. 2, 2000, Str. 165-184. JSTOR. [online]. 2018 [cit. 2019-03-30]. Dostupné z: www.jstor.org/stable/41209050 
- Perspectives on and beyond Asia. ${ }^{6}$ Většina odborných textů $\mathrm{k}$ tématu neokolonialismu je orientována na region Afriky či Latinské Ameriky (poněkud omezeně pak na Asii). Jejich obsahové zaměření je často relativně dosti kritické a jejich autory lze považovat vesměs za poměrně radikální marxisty. ${ }^{7} Z$ česko-jazyčných publikací se problematice postkoloniálních teorií a okrajově také neokolonialismu věnuje např́klad HORKÝ-HLUCHÁŇ, PROFANT a kolektiv v knize Mimo Sever a Jih. Rozumět globálním nerovnostem a rozmanitosti, kde autoři akcentují kritické přistupy k latinsko-americkým, africkým a asijským společnostem, kulturám, náboženstvím, genderovým vztahům či napríklad životnímu prostředí. ${ }^{8}$

Samotný pojem neokolonialismus vznikl v období velké dekolonizace v polovině 20 . století. První kodifikace slova neokolonialismus byla podle zjištěných informací uvedena v oxfordském slovníku v roce 1961, kde původní zdroj (The New Statesman) definoval neokolonialismus jako nejnebezpečnější formu kolonialismu. ${ }^{9}$ Ve spojitosti s pojmem neokolonialismus je potřeba zdůraznit, že se tento termín v posledních desetiletích stal velmi frekventovaným (nejen na poli akademickém), což vedlo $\mathrm{k}$ rožšírení nejasnosti a nejednoznačnosti samotného významu.

Podle dalšího vymezení můžeme neokolonialismus považovat za moderní pokračování kolonialismu, ale už ne formou přímé nadvlády, ale především pomocí ekonomické kontroly dotyčných zemí. $V$ této souvislosti je vhodné odlišovat, zda jde o logickou provázanost ekonomických procesů spojených s celosvětovým trhem zboží a služeb či o partikulární ekonomické zájmy vybraných mocností ve vztahu k ekonomicky slabším státům a využívaní jejich ekonomického potenciálu a zdrojů. $V$ posledních dekádách poměrně rozšířené ekonomické sankce ze strany západních mocností či mezinárodních organizací ve vztahu $\mathrm{k}$ některým diskutabilním státním aktérům (reprezentovaným neliberálními a ne zcela demokratickými režimy) nelze s ohledem na primární význam neokolonialismus považovat za projevy této postkoloniální teorie. Jde velmi často o snahu a nástroje západních mocností vyvažovat ekonomický i politický vliv regionálních státních aktérů v zájmovém teritoriu či na globální scéně. $V$ této kapitole jsou pro názornost uvedeny některé další základní definice neokolonialismu.

Termín neokolonialismus popisuje stav, kdy je původně kolonizovaná země sice formálně nezávislá, ale její vládnoucí elity a klíčoví představitelé se podřizují rozhodnutí bývalé mateřské země (kolonizátora), protože to považují za výhodné pro sebe a někdy

6 ACHARYA, Amitav, BUZAN, Barry. Non-Western International Relations Theory - Perspectives on and beyond Asia. Routledge Taylor \& Francis Group. 2010. ISBN 978-0-415-47473-3.

7 NAGESH, Rao. 'Neocolonialism' or 'Globalization'?: Postcolonial Theory and the Demands of Political Economy. Brown Uviversity - Interdisciplinary Literary Studies, vol. 1, no. 2, 2000, Str. 165-184. JSTOR. [online]. 2018 [cit. 2019-03-30]. Dostupné z: www.jstor.org/stable/41209050

8 HORKÝ-HLUCHÁŇ, Ondřej, PROFANT, Tomáš a kol. Mimo Sever a Jih. Rozumět globálním nerovnostem a rozmanitosti. Ústav mezinárodních vztahů, 2015. ISBN 978-80-87558-18-8.

9 NAGESH, Rao. 'Neocolonialism' or 'Globalization'?: Postcolonial Theory and the Demands of Political Economy. Brown Uviversity - Interdisciplinary Literary Studies, vol. 1, no. 2, 2000, Str. 165-184. JSTOR. [online]. 2018 [cit. 2019-03-30]. Dostupné z: www.jstor.org/stable/41209050 
i pro stát. ${ }^{10}$ Velmi často jsou v mnoha rozvojových zemích však partikulární osobní zájmy vládnoucích autorit nadřazeny obecnému celospolečenskému zájmu a prosperitě.

Neokolonialismus je určitá politická a ekonomická kontrola (forma nadvlády) vyspělých států uplatňovaná na některé rozvojové země, ale na rozdíl od kolonialismu jsou dotčené státy formálně nezávislé, ačkoli fungování státu je ovlivňováno zvenčí. Nástrojem kontroly se nejčastěji rozumí investice ze zahraničí, které ovlivňují ekonomickou i sociální strukturu země, a to primárně ve vztahu k zahraničnímu donorovi. Tento je následně schopen účinně regulovat politickou orientaci ovlivňované země a efektivně využívat ekonomický potenciál i zdroje ve svůj vlastní prospěch a zájmy. Jiným nástrojem může být loutková vláda, kdy je v zemi formální státní nezávislost, ve skutečnosti je správa země podřizena svému „neokolonizátorovi“.11

Rozvojové země jsou často zdrojem levné pracovní síly a $\mathrm{v}$ některých prípadech (včetně například posuzovaného Afghánistánu) také bohaté na suroviny a přírodní zdroje. Související atributy se tak velmi často stávají rozhodujícími faktory, které ovlivňují ekonomické zájmy, surovinovou diplomacii a obecně celou zahraniční politiku vybraných mocností. Neokolonialismus má však i důsledky pozitivní, např. rozvoj technologií, zabezpečení lepších sociálních podmínek, rozvoj vzdělání (stipendia, učitelé ze zahraniči), stavba veřejných budov (školy, nemocnice), investice do dopravních komunikací, stavba elektráren a jiné, ale i negativní důsledky, jako vykořistování, limitované uspokojování základních lidských potřeb (voda, potrava), znečištování životního prostředí, ztráta politické (názorové) svobody a konflikty, at' už mezi mocnostmi nebo uvnitř státu. ${ }^{\mathbf{1 2}}$

Americký on-line slovník Merriam-Webster definuje neokolonialismus jako ekonomické a politické kroky a procesy, pomocí kterých mocnosti udržují či rozšiřují své pưsobení vůči vybrané zemi a jejímu obyvatelstvu. ${ }^{13}$

DANĚK definuje neokolonialismus jako formu hospodářské a politické kontroly vyspělých států, př́padně nadstátních sdružení a institucí, nad hospodářstvím a společnostmi nerozvinutého světa. Ovládané země jsou formálně nezávislé, ale jejich hospodářství a politický systém jsou řizeny zvenčí. Nástroje této kontroly jsou různé, ale často zahrnují prítomnost zahraničního průmyslového a finančního kapitálu. Ten ovlivňuje vnější ekonomické vazby neokoloniálních zemí, ale svojí podporou určitých elit v těchto zemích má dopad i na jejich sociální strukturu. ${ }^{14}$

MENELL popsala neokolonializmus jako poměrně komplikovaný termín s významnou řečnickou mocí, který se týká vlivu zahraničních mocností na politickou a hospodářskou

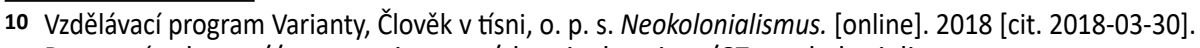
Dostupné z: https://www.varianty.cz/slovnicek-pojmu/67-neokolonialismus

11 Neokolonialismus - Co je neokolonialismus? [online]. 2015 [cit. 2018-03-30]. Dostupné z: http://neokolonialismus.blog.cz/1509/co-je-neokolonialismus

12 lbid.

13 MERRIAM-WEBSTER. Neocolonialism. [online] 2018 [cit. 2019-03-30]. Dostupné z: http://bit.do/eQ33X

14 DANĚK, Petr. Nerovnoměrný rozvoj světa: kolonialismus, neokolonialismus a diskurz rozvoje. In Stát, prostor, politika. Vybrané otázky politické geografie. Praha: Univerzita Karlova, Př́rodovědecká fakulta, 2000. Str. 28 - 58. ISBN 80-238-5566-2. Str. 19. 
dimenzi méně rozvinutých států. K tomuto účelu je ze strany mocností využívána zejména prímá politická kontrola. ${ }^{15}$

Odborně se problematice neokolonialismu věnoval také NKRUMAH v knize $\mathrm{Neo-Co-}$ Ionialism: The Last Stage of Imperialism. ${ }^{16} \mathrm{~V}$ publikaci se autor zaměřuje na analýzu myšlenky kontroly a ekonomické nadvlády na státy, které byly $v$ minulosti koloniemi významných mocností. Je zde zdůrazněno, že ačkoliv proces kolonialismu již skončil, jsou zejména ve vztahu $\mathrm{k}$ africkému kontinentu patrné ekonomické a politické procesy ovlivňující dění ze zahraničí. Vliv externích ekonomických nástrojů má na africkém kontinentě za následek stále se zvětšující rozdíly mezi ekonomicky silnými a slabými státními aktéry. NKRUMAH zdůrazňuje, že ekonomická závislost a podřizenost požadavkům zahraničních mocností významně ovlivňuje možnosti formování blahobytu prostřednictví pouhých vnitropolitických nástrojů jednotlivých podřízených států. Neokolonialismus má podle autorova vymezení následující charakteristiky:

- reálná možnost nasazení vlastních vojenských sil zainteresované mocnosti na území kontrolovaného (podřizeného) státu;

- existující prímé vazby a vlivy umožňující ovládat centrální vládu a další významné politické elity, a to na všech úrovních (centrální, regionální, provinční apod.);

- prokazatelné zahraniční ekonomické nástroje a prostředky určující rozvoj a směřování země;

- důraz v ekonomické oblasti je kladen primárně na rozmach odbytiště a spotřeby zboží pocházejícího ze zahraničí, které již není opatřeno vlastní přidanou hodnotou;

- poskytnutí lidských zdrojů (zahraničních odborníků, poradců apod.) pro mentorování, řizení a kontrolu výkonu státní služby a finančních institucí. ${ }^{17}$

\section{ROLE NEOKOLONIALISMU V AFGHÁNISTÁNU}

$\checkmark$ této kapitole bude role neokolonialismu ve vývoji aktuální bezpečnostní situace v Afghánistánu podrobena konfrontaci s výše uvedenými teoretickými vymezeními a charakteristiky, a to ve vztahu k následující výzkumné otázce determinující zájmy USA v Afghánistánu. Výzkumná otázka tedy explicitně zní: Splňuji americké aktivity v posledních dvou dekádách 21. století v Afghánistánu teoretické požadavky a znaky teorie neokolonialismu?

Obecné faktory expanzivních zahraničních zájmů mocností jako jsou touha po nerostném bohatství jiné země (především rozvojové), levná pracovní síla, snaha o získání surovin a pưdy (nejen stavební, ale i zemědělské) a v neposlední řadě také politický vliv v zemi

15 MENELL, Natasha. China and Africa: the new neocolonialism. The Journal of the Helen Suzman Foundation: 55-60. [online] 2010 [cit. 2019-03-30]. Dostupné z: http://bit.do/eQ34t

16 NKRUMAH, Kwame. Neo-Colonialism: The Last Stage of Imperialism. 1974, Panaf. ISBN 9780901787231.

17 TWEEDIE, Dominic. Neo-Colonialism, the last stage of imperialism by Kwame Nkrumah_Transcribed. [online] 2007 [cit. 2019-03-30]. Dostupné z: https://politicalanthro.files.wordpress.com/2010/08/nkrumah.pdf 
či př́slušném regionu bývají obecným hybatelem společenského, politického i hospodářského dění. Uvedené ukazatele tak nejsou unikátně typické pro neokolonialismus.

Politicky a geostrategicky motivovaná intervence USA (později podpořena prítomností aliančních a koaličních partnerů) byla v roce 2001 zdůvodněna bojem proti stoupencům teroristické organizace al-Kájda, kteří měli na území Afghánistánu využívat základny a útočiště. Po eliminaci vůdce al-Kájdy Usámy bin Ládina a paralyzování značné části organizační struktury uvedené organizace $v$ roce 2011 však nedošlo ke stažení amerických vojsk z Afghánistánu, ale bezpečnostní jednotky USA společně s aliančními a koaličními partnery dodnes v zemi aktivně působí. Zmíněná př́tomnost cizích vojsk na území suverénního státu proto iniciuje množství otázek, jejichž cílem je často nalezení jednoznačné odpovědi na konkrétní zájmy mocností (zejména tedy USA) v Afghánistánu. Formulovat odpovědi na související otázky však není jednoduché. Přesto se někteří odborníci snaží formou souvisejících analýz či odborných článků v kontextu mezinárodních vztahů poskytnout více či méně argumentačně a fakticky podložené pohledy na předmětnou problematiku.

\subsection{Neokolonialismus v Afghánistánu vs. boj proti terorismu}

Zejména levicová sféra politického zastoupení v České republice a také $v$ dalších zemích Evropské unie (a nejen zde) poukazuje na spornou intervenci USA a poté celé aliance i dalších koaličních partnerů do Afghánistánu a zejména setrvání v zemi (do dnešní doby), kdy primárním důvodem již není přitomnost teroristických organizací útočících také na západní cíle, ale naopak politické a ekonomické zájmy USA, jakožto atributů neokolonialismu. Podpůrnými fakty pro uvedené tvrzení jsou zejména výše zmíněná eliminace vůdce al-Kájdy a destrukce organizační struktury. Argumentace bojem proti dalším teroristickým skupinám je dle kritiků velmi často neopodstatněné, nebot' aktuálně samotný charakter a mandát vojenské mise RS (Resolute Support) v Afghánistánu neumožňuje provádět prímo konkrétní protiteroristické operace. Dalším faktorem je vliv sousedního Pákistánu a zejména pákistánská podpora vybraným teroristickým hnutím, jejichž úkolem je destabilizovat bezpečnostní situaci v Afghánistánu a zamezit vzniku a fungování nezávislé, liberální a demokratické vládě. Mimo uvedené má Pákistán s Afghánistánem také dlouhodobý teritoriální spor, a to konkrétně o společnou hranici, jejiž konečná podoba nebyla uvedenými státními aktéry doposud oficiálně ratifikována. Tato sporná otázka je pak zdrojem pákistánských aktivit, které mají významný vliv na destabilizaci bezpečnostní situace v Afghánistánu. Pákistánští představitelé jsou přesvědčeni, že jejich země je utiskována mezi dvěma znepraátelenými sousedy (tedy Afghánistánem a Indií). Rostoucí nenávist mezi Pákistánem a Indií utváří a posilují paranoiu uvnitř pákistánských ozbrojených sil a také uvnitř vládnoucí reprezentace, a to zejména ve vazbě na možné vytvoření vzájemné afghánsko-indické aliance zaměřené právě proti zájmům Pákistánu. Související intenzivní snaha USA vyřešit zmiňovaný hraniční spor (či na řešení sporu participovat) mezi Afghánistánem a Pákistánem nebyl v posledních dekádách zaznamenán.

$\checkmark$ př́padě Afghánistánu je neokolonialistický př́istup USA podpořen také faktem, že tato jihoasijská země disponuje obrovskými zásobami nerostného bohatství. Napríklad 
World Socialist Web Site poukazuje na kroky americké administrativy v Afghánistánu, kdy i po ukončení původně plánované operace NATO (označované ISAF - International Security Assistance Force) zůstalo nadále v zemi mnoho tisíc amerických vojáků. Ve skutečnosti se Afghánistán v posledních více než deseti letech postupně stává americkou základnou (ač zmíněné kroky někdy ve svých prohlášeních současný americký prezident Trump dementuje), ze které americká armáda rozšiřuje svůj vliv v regionu. Afghánistán hraje důležitou roli v plánech Pentagonu v prípadné válce proti Îránu a jako strategicky důležitá základna pro prosazování amerických zájmů ve středoasijských republikách a také v Pákistánu. ${ }^{18}, 19$

Na druhé straně je americká přítomnost v Afghánistánu výhradně zdůvodňována (především pravicově orientovanými politiky, analytiky a zejména samotnou americkou administrativou) jakožto nutný postup v boji proti celosvětovému terorismu. Jeden z hlavních směrů tkvících ve společném boji proti terorismu zdůraznil v České republice například také vojenský analytik Martin Koller. Důvod naší prítomnosti v Afghánistánu a Iráku spatřuji v preventivním boji proti teroristům na jejich vlastním území predtím, než tito fanatici udeři u nás a budou zabijet i české občany. ${ }^{20}$ Po teroristických útocích al-Káidy 11. září 2011 v USA, Spojené státy 7. října téhož roku letecky zaútočily na Afghánistán, kde měla al-Káida své tábory. Následovala pozemní ofenzíva, která vedla $\mathrm{k}$ pádu vlády Tálibánu. Ten se však nikdy nepodařilo zcela porazit a válka v zemi pokračuje dodnes. ${ }^{21}$ Uvedené argumenty liberálně orientované společnosti tedy na druhé straně ve své podstatě odmítají považovat působení USA v Afghánistánu za neokolonialismus.

Provedeme-li konfrontaci základních charakteristik teorie neokolonialismu definovaných například NKRUMAHem (viz kapitola 2) s přístupem USA v Afghánistánu Ize dospět k následujícím závěrům. Reálná přítomnost a praktické nasazení vojenských jednotek USA na území Afghánistánu ovlivňuje od roku 2001 př́mo vývoj bezpečnostní i politické situace v zemi. Př́mé vazby a vlivy umožňující ovládat centrální afghánskou vládu ze strany USA byly v období 2004 - 2014 reprezentovány zejména vládou proamericky orientovaného afghánského prezidenta Hamída KARZÁího. Od roku 2004 docházelo také k podstatnému zlepšování vzájemných vztahů mezi Afghánistánem a Indií. V této souvislosti je velmi zajímavé, že se mnoho klíčových funkcionářů tehdejší vlády prezidenta KARZÁího (včetně KARZÁího samotného) účastnilo speciálních kurzů či studií přímo v Indii. Do dnešní doby je v organizační struktuře GIRoA (Government Islamic Republic of Afghanistan) patrný vliv amerických politiků, diplomatů, expertů a dalších osob pro mentorování, řizení a kontrolu výkonu státní služby a finančních institucí. Rozsáhlé zahraniční investice a také príimé dotace ze strany USA v posledních dvou dekádách 21. století prokazatelně dokládají

18 WorldSocialistWebSite.AfghanistanalsModellfürdenNeokolonialismusdes21.Jahrhunderts. 2013.[online]. 2013 [cit. 2018-03-20]. Dostupné z: https://www.wsws.org/de/articles/2013/01/afgh-j08.html

19 World Socialist Web Site. Das brutale Gesicht des Neokolonialismus in Afghanistan. 2013. [online]. 2013 [cit. 2018-03-20]. Dostupné z: https://www.wsws.org/de/articles/2013/04/11/afgh-a11.html

20 Hyde Park ČT24. TV, ČT24. 25. listopadu 2010. 20:10. [online]. 2010 [cit. 2018-03-20]. Dostupné z: http://www.ceskatelevize.cz/porady/10252839638-hyde-park-ct24/210411058081125-hyde-park/

21 Novinky.cz - Teroristický útok z 11. záŕí 2001 v New Yorku a Washingtonu. [online]. 2018 [cit. 2018-0320]. Dostupné z: https://tema.novinky.cz/teroristicky-utok-z-11-zari-2001-v-new-yorku -a-washingtonu 
existenci potřebných amerických ekonomických nástroje a prostředků k určujícímu rozvoji a směřování Afghánistánu, a to zejména v kontextu amerických zájmů. Snaha USA o penetraci svého zboží na afghánský domácí trh je aktuálně limitována, a to s ohledem na logistické limity, které neumožňují efektivní transport potravin. Mimo zmíněné faktory je afghánské tržní odbytiště velmi významně pokryto produkty ze sousedních zemí, především tedy z Pákistánu, Íránu a ČLR. V této souvislosti je však potřeba zdůraznit, že nezanedbatelná komunita mezinárodních bezpečnostních sil působících v Afghánistánu je majoritně logisticky zajištóvána ze strany amerických subjektů.

Hlavní motivy neokolonialismu v jižní Asii, respektive konkrétně v Afghánistánu jsou založeny na ekonomických a politických stimulech. Jde zejména o existenci velkého potenciálu afghánského nerostného bohatství, dále pak o vyvažování vlivu USA v regionu ve vztahu $k$ působení a prosazování zájmů ČLR, Pákistánu, Indie a částečně i RF. Mimo uvedené je potřeba dále zmínit také snahu USA monitorovat veškeré aktivity v regionu a prezentovat svou vojenskou sílu ve vazbě na Írán, jakožto potencionálního amerického protivníka. Afghánistán je svou strategickou polohou pro USA vhodný také v souvislosti s prosazováním zájmů ve středoasijských republikách (Turkmenistán, Uzbekistán a Tádžikistán), a to s ohledem na omezování historického vlivu ze strany RF.

\subsection{Vliv neokolonialismu na stabilizaci bezpečnostní situace v Afghánistánu}

Afghánistán a jeho budoucnost jsou závislé na skutečné transformaci státního zřízení s prvky základních demokratických principů, které vyžadují odpovídající změny, a to nejen v oblasti afghánských bezpečnostních institucí, vnitrostátního politického systému či například lidských práv. Mír v Afghánistánu bude možný pouze v prípadě, že základní tužby a potřeby afghánské populace budou respektovány a nadřazeny individuálním zájmům klíčových vưdčích osobností či jednotlivých skupin. Toho musí být dosaženo v kontextu vzájemné shody a v úzké spolupráci USA s regionálními subjekty a mezinárodními partnery. ${ }^{22}$ Aktuálně můžeme poukázat minimálně na šest základních sporných otázek a jejich aktéry, kteři determinují konflikt a samotnou bezpečnostní situaci v Afghánistánu. Jsou to zejména:

- válka proti terorismu, kdy spouštěcím indikátorem bylo rozhodnutí americké administrativy eliminovat aktivity teroristické organizace al-Kájdy po útocích v USA v září 2001;

- indicko-pákistánský zamrzlý konflikt, kdy se Pákistán snaží eliminovat vliv Indie v Afghánistánu představující pro Pákistán klíčové teritorium v rámci prípadného konvenčního konfliktu. $Z$ tohoto důvodu je vysoce pravděpodobné, že na afghánském území aktivně a dlouhodobě operují příslušníci zpravodajských služeb Pákistánu i Indie s cílem podporovat prosazování vlastních národních zájmů;

22 THIER, Alexander J. The Future of Afghanistan. Washington, D.C., 2009. First pub. United States Institute of Peace. Str. $1-109$. 
- sunnitsko-šíitský konflikt reprezentovaný vůdci hlavních konfesí islámského světa, tedy zástupců Saúdské Arábie a Íránu, kteří se v Afghánistánu snaží prosadit své vlastní (nábožensky orientované či ekonomické) zájmy;

- prítomnost koalice NATO vedené USA a dalších partnerů (např. Austrálie, Gruzie apod.), kteří se v rámci jednotlivých operací (RS, ISAF, OEF apod.) snaží stabilizovat situaci $v$ zemi a podporovat rozvojové a usmiřovací projekty i procesy;

- př́stup Ruské federace $k$ př́tomnosti sil NATO v zájmovém regionu jižní Asie je dlouhodobě konzistentní s cílem zamezit permanentní přitomnosti NATO v oblasti. Přestože původně Ruská federace podporovala boj proti terorismu (včele s organizací al-Kájda) či eliminaci produkce drog v Afghánistánu, je dlouhodobé působení NATO včele $s$ USA pro RF neakceptovatelné. RF považuje základny NATO ve svém okolí za jistou formu ohrožení vlastních zájmů;

- existence potencionálního konfliktu mezi USA a Íránem, kdy USA mimo jiné využívá Afghánistán jako svou základnu proti prípadnému působení vůči Íránu. V posledních letech jsou také patrné snahy Íránu podporovat některé frakce afghánských povstalců, a to zejména $v$ jejich boji proti prítomnosti USA. ${ }^{23}$

$\checkmark$ rámci stabilizace země by měly obecně všechny vlády vycházet z následujících pěti základních principů:

- vláda musí mít jasné politické cíle směřované k vytvoření a udržování svobodné, nezávislé a sjednocené země, která je politicky a ekonomicky stabilní;

- vláda musí postupovat a jednat v korelaci s existujícími právními normami;

- vláda musí mít komplexní plány a strategie ve všech možných oblastech;

- vláda musí mít stanoveny priority jak čelit politické subverzi (podvratné činnosti) a gerilovému (asymetrickému) způsobu boje;

- v prípadě gerilového boje musí vláda zajistit primárně a v první fázi bezpečnost klíčovým a základním subjektům (strategická města, centra, komunikace, strategické objekty apod.). ${ }^{24}$

Úsilí mezinárodních sil včele s USA stabilizovat situaci v Afghánistánu závisí velmi významně na Pákistánu a jeho podpoře Talibanu. Afghánští představitelé i afghánské civilní obyvatelstvo stále intenzivněji obviňuje Pákistán a jeho zpravodajskou službu ISI (Inter Service Intelligence), že stojí v pozadí povstaleckých aktivit na afghánském území. Podpora afghánských militantů ze strany Pákistánu koresponduje s dlouhodobou národně-bezpečnostní politikou a strategií Pákistánu orientovanou proti zájmům Indie v regionu. Pákistán se mimo jiné zaměřuje také na rozsáhlé ovlivňování veřejného mínění a místních médií, a to nejen šířením vlastních narrativů, ale také zastrašováním novinářů či občanských aktivistů a kritiků armády. Mimo již zmíněné, afghánský Taliban dále pomáhá vytvářet pro Pákistán nepostradatelné útočiště na paštunských územích, a to

23 THIER, Alexander J. The Future of Afghanistan. Washington, D.C., 2009. First pub. United States Institute of Peace. Str. 16.

24 ELYAS, Mohammad. Insurgency and Terrorism in India and Pakistan - With Special Reference to Benazir Bhutto. New Delhi, 2008, MD Publications Pvt Ltd. ISBN 978-81-7533-117-4. Str. 18. 
pro př́padný ústup při konfliktu s Indií. Někteří představitelé americké administrativy v minulosti prezentovali, že není možné konflikt v Afghánistánu vyhrát, dokud má Taliban $\mathrm{k}$ dispozici pákistánskou podporu a zejména bezpečná útočiště v Pákistánu. Pákistán na uvedená prohlášení reagoval zadržením několika méně významných velitelů Talibanu s cílem zmírnění amerického tlaku. $V$ reálných podmínkách se však pákistánský př́stup $\mathrm{k}$ afghánskému Talibanu nijak zásadně nezměnil. ${ }^{25}$

Skutečná stabilita konkrétního státu ( $v$ našem případě Afghánistánu) existuje tehdy, věří-li majoritní část jeho obyvatelstva v legitimitu své vlády. Mezi hlavní pilíre stability bezpečnostní situace v Afghánistánu musí patřit bezpečnost (kolektivní bezpečnost, individuální bezpečnost, vybudování bezpečnostních struktur apod.), právo a poráaek (právní řád, soudní systém, vězeňství atd.), ekonomický rozvoj a zvyšování životní úrovně obyvatelstva, stabilní vláda a participace občanů na vládě. $V$ této souvislosti by mělo být tedy zejména zabezpečeno, aby:

- afghánská vláda GIRoA (Government Islamic Republic of Afghanistan) posílila státní strukturu a byla schopna explicitně přesvědčit afghánské obyvatelstvo, že je reálně schopna a také ochotna uspokojit jejich základní potřeby;

- afghánská vláda byla schopna efektivně a plně kontrolovat vnitřní bezpečnost i vnější hrozby (včetně problematické propustnosti afghánsko-pákistánské hranice) a vlastnila výhradní monopol na použití silových prostředků ve vztahu k suverenitě a územní celistvosti;

- afghánská vláda oživila a posílila ekonomickou situaci země nutnou k posílení kupní síly afghánského obyvatelstva, uspokojení všech souvisejících základních potřeb a eliminování významné problematiky chudoby;

- afghánská vláda v ekonomické oblasti snížila závislost na zahraničních dotacích a expandovala ve vztahu k využívání surovinového bohatství země;

- sociální prostředí a s ním spojené aktivity efektivně podporovaly rozvoj regionů, provincií, distriktů a významných městských center v Afghánistánu;

- veškeré afghánské obyvatelstvo přednostně využívalo při řešení konfliktních situací a nejrůznějších sporů jiné formy než aktuálně velmi rozšířeného násilí;

- veškeré aktivity afghánské vlády s podporou mezinárodního společenství reflektovaly místní kulturní, kmenové či náboženské zvyklosti a další související principy afghánského etnicky poměrně diverzifikovaného obyvatelstva.

Pro zevrubnější pochopení jsou konkrétní faktory a kroky potřebné ke stabilizaci komplexní situace $v$ Afghánistánu uvedeny na obrázku č. 1, kdy bylo k jejich členění využito

25 BACON, Tricia. Slipping the Leash? Pakistan's Relationship with the Afghan Taliban. Survival - Global Politics and Strategy. Washington, D.C., 2018, vol. 60 no. 5. The International Institute for Strategic Studies. Str. $159-175$. 
principu analýzy PMESII/26, která byla dále doplněna o oblast zahrnující bezpečnostní problematiku (viz oranžově podbarvená část schématu).

\subsection{Deformace sil regionálních aktérů v Afghánistánu v důsledku angažovanosti USA v oblasti}

Pákistán je nedílnou součástí regionálního komplexu v kontextu svých vztahů vůči Afghánistánu, a to nejen $\mathrm{s}$ ohledem na etnickou či náboženskou provázanost. Kořeny sahají hluboko k samotnému vzniku nezávislého Pákistánu. Hlavní roli v rámci interakce s Afghánistánem reprezentuje více než století stará Durandova linie ${ }^{27}$, která dodnes utváŕí určitou imaginární geografickou hranici mezi oběma státy. Vymezená linie rozdělila paštúnskou etnickou skupinu na dvě části, které se na začátku 20. století ocitly ve dvou rozdílných státech. To přispělo $k$ celkové etnické fragmentaci afghánské společnosti a k neschopnosti určit majoritní státotvornou skupinu. ${ }^{28}$ Etnická a kmenová př́slušnost je tak jedním z hlavních faktorů ovlivňujících pákistánskou zahraniční politiku ve vztahu k afghánskému prostoru. ${ }^{29}$ Je však nutné reflektovat i skutečnost, že ani Pákistán ani Afghánistán není ochoten respektovat separaci vlastního státu a vytvoření nezávislého Paštúnistánu, o kterém dlouhodobě uvažují Paštúni - zástupci tohoto majoritního afghánského etnika. Americký neokolonialismus Afghánistánu má také př́mý dopad na rozsáhlé údery amerických bezpilotních prostředků na pákistánských územích, které jsou využívány jako útočiště pro teroristy.

Z geopolitického hlediska představuje Afghánistán taktéž určitou výzvu i pro Indii. Tento velmi lidnatý stát disponuje jadernou kapacitou a postupně se profiluje do pozice regionální mocnosti s poměrně rozsáhlou sférou vlivu, včetně nedalekého Afghánistánu. Indie má z historického pohledu pozitivní vztahy s Afghánistánem, za kterými stojí snaha získat ho na svou stranu jako protipól úhlavního nepř́tele Pákistánu. ${ }^{30}$ Vzájemná rivalita mezi Indií a Pákistánem je jedním ze základních piliřru, na kterém je postavena geopolitika indického subkontinentu. Ta je i v dnešní době velmi citlivou tematikou vzhledem

26 PMESII či PMESII-PT značí konkrétní analytickou metodu operačního prostředí a její název je akronymem odvozeným od počátečních písmen jednotlivých dimenzí, kterým se analýza při posuzování a rozboru prostředí věnuje. Konkrétně jde o následující dimenze: P-Political (politická), M-Military (vojenská), E-Economic (ekonomická), S-Social (sociální), I-Information (informační), I-Infrastructure (infrastrukturální), P-Physical Environment (fyzického prostředí) a T-Time (časová).

27 Afghánistán byl především v 19. století významnou oblastí britsko-ruského soupeření známého pod historickým pojmem The Great Game. Na konci zmiňovaného 19. století (konkrétně v roce 1893) byla definována demarkační linie mezi Afghánistánem a Britskou Indií, takzvaná Durandova linie, která vymezuje současnou afghánsko-pákistánskou hranici a rozděluje paštunská kmenová území.

28 RAIS, Rasul Bux. Recovering the frontier state: war, ethnicity, and state in Afghanistan. Lanham, MD: Lexington Books, 2008. ISBN 0739109561. Str. 182.

29 HYNEK, Nik, EICHLER, Jan a MAJERNÍK, L'ubomír. Konflikt a obnova v Afghánistánu: kontext, prostředi a zájmy. Praha: Ústav mezinárodních vztahů, 2012. ISBN 978-80-87558-06-5. Str. 48.

30 WOLPERT, Stanley A. India. 4th ed., [2009 ed.]. Berkeley: University of California Press, 2009. ISBN 978-0520260320. Str. 244. 

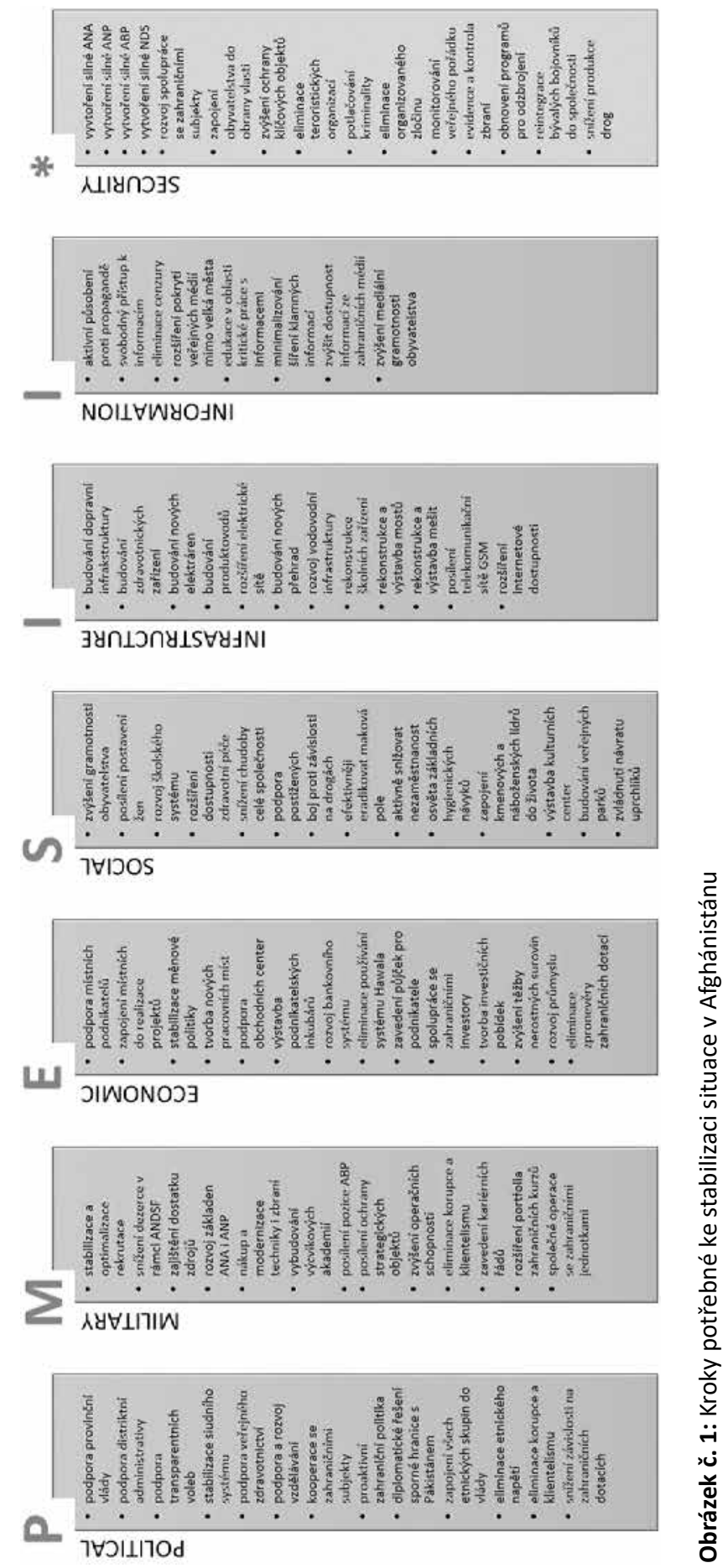
k teritoriálnímu sporu mezi Indií a Pákistánem o území Kašmíru. ${ }^{31}$ Regionální geopolitika je tak s přihlédnutím na vlastnictví jaderných zbraní Indie i Pákistánu značně bipolární z hlediska její vnitřní dynamiky. ${ }^{32}$ Po roce 2001 je však zjevný určitý obrat v této interakci způsobený vysokou rychlostí všeobecného růstu a rozvoje Indie. ${ }^{33}$

S ohledem na působení vojsk aliance $v$ rámci mise RS (Resolute Support) ${ }^{34}$ jsou v celém operačním prostoru (tedy na celém území Afghánistánu) zásadně omezeny jakékoliv aktivity pákistánských či indických bezpečnostních sil. Zejména pro prvně zmiňovaný Pákistán je př́tomnost koaličních vojsk značným limitním faktorem, který omezuje dlouhodobé pákistánské zájmy v Afghánistánu. Přestože jak Pákistán, tak i Indie, jsou spojenci USA, je v př́padě Pákistánu možné kvaziperiodicky sledovat diplomatický nátlak a určité vyostření vzájemných vztahů, které korelují s údajně nedostatečným postupem pákistánské vlády a bezpečnostních složek vůči teroristickým organizacím na problematických územích západního Pákistánu, které hraničí s Afghánistánem. Dále je nutné zmínit, že neexistence kontinuální a oboustranně střežené hranice mezi Afghánistánem a Pákistánem dává podnět pro pákistánské bezpečnostní složky, angažovat se také na př́íhraničním území Afghánistánu a podporovat své zájmy (nejen ty, jež mají vztah k případné vojenské konfrontaci s Indií).

Indie se mimo běžné diplomatické aktivity a dlouhodobé ekonomické zájmy nijak blíže zejména vojensky v Afghánistánu neangažuje. Naproti určité nevraživosti mezi př́slušníky bezpečnostních sil Pákistánu a Afghánistánu, je situace mezi Afghánistánem a Indií v oblasti bezpečnostní spolupráce poněkud odlišná. Indie se v Afghánistánu, na rozdíl od členů NATO a dalších koaličních partnerů, nepodílí prímo vojensky, ale poskytuje množství vojenských i policejních kurzů zejména pro afghánské důstojníky ve výcvikových zařízeních v Indii.

Jak je patrné z výše uvedených informací, jsou dopady amerického neokolonialismu v Afghánistánu velmi významné pro prosazování vlastních zájmů Pákistánu i Indie v zemi. Př́tomnost hegemona reprezentovaného USA značně limituje zejména vlastní aktivity Pákistánu uvnitř Afghánistánu, kdy je Pákistán nucen své aktivity provádět skrytě, utajeně a prostřednictvím jiných subjektů a aktérů (nejen například pomocí aktivit hnutí Tálibán).

31 WIRSING, Robert. India, Pakistan, and the Kashmir dispute: on regional conflict and its resolution. New York: St. Martin's Press, 1994. ISBN 0312084420. Str. 2.

32 BUZAN, Barry, WVER, Ole. Regions and powers: the structure of international security. New York: Cambridge University Press, 2003. Cambridge studies in international relations, 91. ISBN 978-0-521-89111-0. Str. 106.

33 HYNEK, Nik, EICHLER, Jan a MAJERNÍK, L'ubomír. Konflikt a obnova v Afghánistánu: kontext, prostředí a zájmy. Praha: Ústav mezinárodních vztahů, 2012. ISBN 978-80-87558-06-5. Str. 52.

34 Více viz např. na https://rs.nato.int/about-us.aspx 


\section{ZÁVĚR}

S postupujícím časem se začínají v souvislosti s neokolonialismem více zvýrazňovat některé závažné problémy vedení konfliktu v etnicky a klanově velmi fragmentovaném afghánském prostředí. Přestože je na mezinárodní scéně stále častěji skloňována samotná legitimita toho, zda americká př́tomnost v Afghánistánu má čistě podtext neokolonialismu či záměru boje proti terorismu, je vliv této světové mocnosti v zemi i regionu neoddiskutovatelný a je nadále předmětem mnoha studií. Neokolonialismus jako jedna z konkrétních postkoloniálních teorií se od poloviny 20. století stále častěji diskutovala, a to zejména $v$ souvislosti s prosazováním zájmů klíčových světových mocností $v$ čele s ČLR a USA. Mnoho odborných publikací, studií a článků věnuje v prípadě neokolonialismu pozornost především surovinové diplomacii ČLR v některých státech na africkém kontinentu či v Latinské Americe. V posledních letech Ize však pozorovat orientaci ČLR na rozšiřování svého vlivu také v samotné Asii a dokonce i v Evropě. Toto dokumentuje také snaha ČLR o vybudování tzv. Nové hedvábné stezky. S ohledem na popsané čínské kroky je pak zcela logické, že se další globální hráč, tedy USA, snaží všemi dostupnými nástroji a prostředky vyvažovat rostoucí vliv a zájmy ČLR v celosvětovém měřítku. Do těchto aktivit zapadá také samotná angažovanost USA v Asii, výše popisovaný Afghánistán nevyjímaje. Mimo mocenské soupeření zmiňovaných USA a ČLR v regionu jižní Asie je v kontextu tohoto článku potřeba zdůraznit také konfrontaci zájmů a sil dalších regionálních aktérů v čele s Pákistánem a Indií. Obě uvedené země mají s ohledem na historické konotace v Afghánistánu své zájmy, které jsou však vzájemně protichůdné. Je proto pochopitelné, že neokoloniální přístup USA (okrajově i ČLR) v Afghánistánu determinuje dynamicky v čase také úroveň vlivu Pákistánu i Indie. Veškeré uvedené faktory mají ve svém důsledku nezastupitelný vliv na formování institucionálního prostředí nezávislého Afghánistánu (jakožto suverénní země, které nebyla v moderní historii nikdy kolonizována) a především na stabilizaci bezpečnostní situace.

Autor: $\quad$ Ing. Martin HAVLÍK, Ph.D., MBA, Msc. Pracovník Ministerstva obrany České republiky. Specializuje se na oblast managementu informací a dlouhodobě na analýzy bezpečnostních hrozeb a rizik v oblastech konfliktů s dopadem na obranu a bezpečnost České republiky.

Jak citovat: HAVLÍk Martin. Role neokolonialismu ve vývoji bezpečnostní situace v Afghánistánu. Vojenské rozhledy. 2019, 28 (3), 026-040. ISSN 1210-3292 (print), 2336-2995 (on-line). Available at: www.vojenskerozhledy.cz. 


\section{Obléhání Marawi, impulz změnit schopnosti filipínských ozbrojených sil}

\section{The Siege of Marawi, the impulse to change the capabilities of the Philippine armed forces}

\section{Libor Kutěj}

Abstrakt: V květnu 2017 obsadili islamisté jihofilipínských separatistických skupin Abú Sajjáf a Maute město Marawi na ostrově Mindanao. Pětiměsíčních bojů se zúčastnilo více než 3000 příslušníků ozbrojených sil proti asi 1000 džihádistům. Na straně islamistů se bojů zúčastnilo několik desítek zahraničních bojovníků, kteří potvrdili panislámský étos ideologie Islámského státu v této části světa. Filipínské jednotky, nebyly na charakter bojů $v$ urbanizovaném prostředí proti motivovaným a zkušeným militantům připraveny. Nedostatky se projevily ve výcviku k vedení operací v silně zastavěném území, nízké úrovni koordinace a v omezených schopnostech zpravodajské podpory technickými prostředky průzkumu. Zkušenosti z konfliktu iniciovaly změnu doktrinálního př́stupu, který se zaměřuje na vzdušnou podporu, která by omezila ztráty vlivem nepřesného bombardování a akvizice technologicky vyspělých prostředků průzkumu a zbraňových systémů.

Abstract: In May 2017, Islamists of the South-Philippine Separate Groups of Abu Sajyaf and Maute occupied Marawi City in Mindanao. Five-month fighting was attended by more than 3,000 armed forces against about 1,000 jihadists. Dozens of foreign fighters took part in the fighting on the Islamists side and confirming the pan-Islamic ethos of the Islamic state's ideology in this part of the world. Philippine troops were not prepared for the character of fighting in urbanized environment against motivated and experienced militants. The shortcomings were manifested in the conducting of operations in a heavily built-up area, but also in low-level coordination and limits of capabilities of the technical intelligence. The conflict experience has initiated a change of doctrinal approach that focuses on air support to reduce losses due to inaccurate bombing and acquisitions of high-tech reconnaissance and weapon systems.

Klíčová slova: Abú Sajjáf; Islámský stát; Maute; speciální síly; zpravodajská podpora.

Keywords: Abu Sayyaf; Islamic State; Maute Group; Special Forces; Intelligence Support. 


\section{ÚVOD}

Diskurz o tzv. Islámském státu ${ }^{1}$ se $v$ evropském prostoru vede téměř výlučně ve vztahu k jeho existenci a aktivitám v blízkovýchodním prostoru, zejména pak v Iráku a Sýrii, případně v oblasti severní a subsaharské Afriky. Tradiční vnímání hrozby Islámského státu je v územních oblastech jeho vzniku. Teritoriální limity zájmu politických představitelů a vojenských stratégů Evropy a zemí Blízkého východu jsou pochopitelné, jelikož vycházejí nejen z geografické blízkosti, ale též z dlouhotrvající provázanosti v obchodní sféře, vytvořených personálních vazeb a určitého kulturního kontextu.

Předmětem zkoumání bezpečnostních analytiků a mediálních expertů se stále více stávají islamistická uskupení, která jsou samotnému Blízkému východu geograficky velmi vzdálená, avšak svým ideologickým poselstvím, deklarovanými cíli a způsobem jejich naplňování se původnímu Islámskému státu zcela vyrovnají. Při respektu ke skutečnosti, že okolo 240 miliónů obyvatel jihovýchodní Asie představují muslimové (což znamená 42 \% veškerého obyvatelstva tohoto regionu a $25 \%$ z celkového počtu vyznavačů islámu na světě) ${ }^{2}$, stává se oblast jihovýchodní Asie přirozeným prríjemcem myšlenek radikálního islámu v jeho nejmilitantnější formě.

V návaznosti na stále více zřejmý úpadek struktur uskupení teroristické organizace, ${ }^{3}$ jako př́mého důsledku její vojenské porážky, se do popředí derou skupiny militantního islámu, které deklarovaly svou věrnost Islámskému státu, a které se snaží jeho ideály a metody šířit v jiných oblastech světa, zpravidla s početně významnou muslimskou populací. Afilace v jihovýchodní Asii zpravidla nepředstavují zcela nová uskupení, jež by se na scéně mezinárodního terorismu objevila znenadání a budovala své schopnosti na zelené louce. Vycházejí ze zavedených organizačních struktur, široké personální základny, relativně moderní výzbroje a především historickými zkušenostmi z desetiletí vedených bojů se státní mocí. Dlouhověkost skupin je určována mírou jejich popularity u místního obyvatelstva a provozními aspekty, mezi které Ize řadit především zahraniční podporu a přístup ke zbraním a dalšímu vojensky využitelnému materiálu a dalšímu vybavení. Základem skupin jsou ozbrojená separatistická hnutí, jejichž původním motivem vzniku a bojových aktivit byl étos národního sebeurčení - územní a sociálně-kulturní nároky muslimské části obyvatelstva ve státních útvarech jihovýchodní Asie. Po událostech 11. zárí 2001 a zejména se vznikem Islámského státu se dosud převažující religiózní

1 Islámskýstát(téžznámjakoIslámskýstátv|rákua Levantě)jesunnitskádžihádistickáskupinausilujícíovytvoření chalifátu s autoritou nad všemi muslimy. Vznik byl inspirován al-Kájdou, ze které však byl později veřejně vyloučen. Ref. The Islamic State (Terrorist Organization). [online]. Santa Monica, Ca.: RAND Corporation. [cit. 2019-03-14]. Dostupné z: https://www.rand.org/topics/the-islamic-state-terrorist-organization.html).

2 IMTIYAZ, Yusuf. The Middle East and Muslim Southeast Asia: Implications of the Arab Spring [online]. Oxford: Oxford University Press. [cit. 2019-03-19]. Dostupné z: http://www.oxfordislamicstudies.com/Public/focus/essay1009_southeast_asia.html.

3 Islámský stát byl na seznam zahraničních teroristických organizací ministerstva zahraničí USA zařazen dne 17. 12. 2004. Ref. Foreign Terrorist Organizations. [online]. Washington, D. C.: U. S. Department of State. [cit. 2019-03-14]. Dostupné z: https://www.state.gov/j/ct/rls/other/des/123085.htm). 
separatismus stal základem nové formy prosazování nároků, militantně reprezentovaných ozbrojenými organizacemi.

Změna charakteru etnoregionálního konfliktu se projevila v řadě zemní jihovýchodní Asie, nicméně asi nejvýraznějšího projevu se jí dostalo před dvěma roky na jihu Filipínské republiky, kde několikaměsíční ozbrojený střet s afilacemi Islámského státu odkryl nejen nový ideologický rozměr, mezinárodní propojení a spolupráci džihádistických skupin, ale též nepřipravenost bezpečnostních složek na nový fenomén hrozby a měnící se podmínky ozbrojeného střetu. Cílem článku je uvést složitost faktorů, které vedou k teroristickým hrozbám a způsobům boje proti nim, včetně implementace preventivních opatření.

\section{HISTORICKÁ PODSTATA OZBROJENÉHO SEPARATISMU FILIPÍNSKÝCH MUSLIMŮ}

Islám se do oblasti jižních Filipín dostává přinejmenším od konce 13. století, kdy na severu Sumatry vzniklo první muslimské knížectví a kdy v roce 1380 připlul do oblasti Suluského souostroví arabský misionář Karím al-Machdúm, který je považován za zakladatele první mešity na Filipínách. ${ }^{4}$ Islám si postupně získal tak zanícené stoupence, že za celých 330 let španělské nadvlády se kolonizátorům podařilo v oblasti jižních Filipín prosadit svou nadvládu jen formálně. Jejich následovníci, Američané, vytvořili v roce 1903 z jihofilipínských ostrovů provincii Moros ${ }^{5}$ pod vojenskou správou, která zlikvidovala zbytky proslulého pirátství a banditismu a sultána ze Sulu donutila, aby se v roce 1915 vzdal světské moci. Konsolidace regionu však postupovala pomalu a teprve v roce 1940 byl zrušen suluský sultanát a jeho území bylo začleněno do tehdy již nezávislé Filipínské republiky. $^{6}$

Nezávislost přinesla v 50. a 60. letech 20. století vládou podporovaná masivní migrace křestanů, zejména ze střední části Filipín na muslimský jih. ${ }^{7} \mathrm{Na}$ prelomu 60 . a 70 . let pod ideou národního sebeurčení propuklo muslimské ozbrojené povstání na Mindanau a Suluském souostroví. Do čela povstání se postavila Fronta národního sebeurčení Morů8 (Moro National Liberation Front, MNLF) založená v roce 1969. První výcvikové tábory vznikaly v Malajsii, která povstalce též společně s některými státy Blízkého východu

4 VONDRA, Pavel. Filipíny. Praha: Libri, 2016, 184 s. Stručná historie států. s. 16-34. ISBN 978-80-7277-511-8.

5 Označení poprvé použili španělští kolonizátoři, kteří s ohledem na stejnou víru a podobný odpor proti kolonizaci srovnávali filipínské muslimy se severoafrickými Maročany - Maury (pozn. autora).

6 ŠLACHTA, Mojmír, BURDA Tomáš a HOLEČEK Milan. Ohniska napětí ve světě. Praha: Kartografie Praha, 2007, 192 s., s. 145. ISBN 978-80-7011-926-6.

7 McKENNA, Thomas M. The Origins of the Muslim Separatist Movement in the Philippines. Asia Society [online]. New York [cit. 2019-03-20]. Dostupné z: https://asiasociety.org/origins-muslim-separatist-movement-philippines.

8 Označení poprvé použili španělští kolonizátoři, kteří s ohledem na stejnou víru a podobný odpor proti kolonizaci srovnávali filipínské muslimy se severoafrickými Maročany (pozn. autora). 
a severní Afriky (např. Libyí) finančně podporovala. ${ }^{9}$ Od této doby Ize zaznamenat trvalé vměšování zahraničních entit do permanentního etnoregionálního konfliktu.

V listopadu 1990 na základě nové ústavy vzniká Autonomní oblast muslimské Mindanao (Autonomous Region of Muslim Mindanao, ARMM). ${ }^{10}$ Mírová jednání byla završena komplexní mírovou dohodou v roce 1996 a byla v souladu s ústavou ohledně existence a správy ARMM. V současnosti však nejsou uzavřené dohody funkční, a to jednak pro neochotu vlády předat dohodnuté kompetence do rukou autonomních orgánů, a jednak pro ozbrojený odpor některých muslimských skupin proti samotné filozofii autonomie. ${ }^{11}$ Jednou z nejvíce aktivních organizací, které se nesmířily s myšlenkou autonomie, je Islámská osvobozenecká fronta Morů (Moro Islamic Liberation Front, MILF), jež vznikla odtržením od MNLF, a která se pod vůdcem šejchem Hašímem Salamatem prezentuje odhodláním bojovat za úplné odtržení muslimských provincií od Filipínské republiky. ${ }^{12}$

\section{NÁRŮST SCHOPNOSTÍ A BOJOVÝCH ZKUŠENOSTÍ MUSLIMSKÝCH SEPARATISTUீ, VZNIK ABÚ SAJJÁF}

Bez ohledu na průběh povstání v 60. a 70. letech došlo k důležitému zvratu v bojových schopnostech filipínských muslimů po sovětské invazi do Afghánistánu. Obdobně jako v jiných islámských zemích americká CIA podporovala na afghánském bojišti džihádisty přicházející z Filipín. Bojů proti SSSR se účastnili jak z ideologických důvodů, tak kvůli finančnímu zisku. Nezanedbatelným motivem byla prestiž navrátivších se bojovníků v místní muslimské komunitě. Filipínští džihádisté se po návratu do vlasti stávali přirozenými vůdci již dříve existujících separatistických skupin, jejichž činnosti dávaly nový ideologický rozměr svou afghánskou zkušeností v boji proti „křižákům“, reprezentovaným jednotkami sovětské armády. Na Filipíny se z afghánského válčiště navrátilo okolo 500 bojovníků, kteří zůstali ve spojení nejen s ostatními filipínskými džihádisty, ale udržovali kontakty se svými bývalými spolubojovníky z Indonésie, Malajsie a zemí Blízkého východu. Z těchto zemí přicházela filipínským mudžahedínům finanční a materiální podpora. Filipínští muslimové již od 80 . let sdíleli se seniorními lídry al-Kájdy myšlenku zř́zení chalifátu. ${ }^{13}$

9 VONDRA, Pavel. Filipíny. Praha: Libri, 2016, 184 s. Stručná historie států. s. 114. ISBN 978-80-7277-511-8.

10 Ref. 6, s. 147.

11 Ref. 4.

12 Rozhovor autora vedený dne 19.11. 2018 s důstojníkem filipínské zpravodajské služby působícím v oblasti boje proti terorismu v oblasti Mindanao.

13 lbid. 
Nejznámější skupinou, která se od počátku své existence projevovala velmi radikální militantní ideologií a krutou teroristickou činností je Abú Sajjáf ${ }^{14,15}$ Skupina se zformovala odtržením od MNLF v roce 1991 pod vedením Abdu Raji Janjalaniho. Studoval na Blízkém východě a postupně se radikalizoval v průběhu svých pobytů v Saúdské Arábii, Libyi a dalších zemních regionu. Při studiu íránské revoluce v roce 1988 se údajně v Pákistánu setkal s Usámou bin Ládinem, po jehož boku měl údajně bojovat v Afghánistánu. Janjalani vytvořil Abú Sajjáf z dalších nespokojených členů MNLF, kterým se dosavadní ozbrojený odpor zdál málo radikální. Po celou dobu své existence v 90 . letech získával Abú Sajjáf (mimo finančních příspěvků al-Kájdy ze zahraničí) zdroje vydíráním, únosy bohatých Filipínců, zejména křest'anů a cizinců. Za cíle teroristických útoků si vybíral představitele a objekty filipínské státní moci a především armády a bezpečnostních složek. Plánované útoky byly $v$ souladu s dlouhodobě deklarovaným konečným cílem skupiny, a to vzdorovat filipínské vládě do okamžiku vzniku nezávislého muslimského státu. Pro extrémně násilné praktiky uplatňované skupinou Abú Sajjáf se od činnosti a cílů distancovaly MNLF i MILF. ${ }^{16} \mathrm{~V}$ počátečních letech existence Abú Sajjáf operovala jako soudržná a explicitně religiózní organizace. Ztráta několika zkušených a respektovaných vůdců vedla $\mathrm{k}$ fragmentaci hnutí do menších skupin s jejich zaměřením na kriminální činnost. V současnosti je personální síla organizace odhadována na méně než 100 členů. ${ }^{17}$

\section{OBSAZENÍ MARAWI ISLAMISTY}

Město Marawi se nachází v západní části druhého největšího filipínského ostrova Mindanao. Podle posledního sčítání lidu v roce 2015 je obydleno cca 200000 obyvateli a je tak populačně největším městem v rámci oblasti ARMM. Od počátku príchodu islámu ve 14. století je Marawi dominantně muslimským městem a v roce 1980 městská rada vydala rezoluci, na základě které se město oficiálně nazývá Islámské město Marawi. Je hlavním městem provincie Lanao del Sur podle stejnojmenného jezera, na jehož severním okraji se město nachází. ${ }^{18}$

Dne 23. 5. 2017 se v Marawi střetly filipínské bezpečnostní složky se dvěma organizacemi, které vyhlásily věrnost Islámskému státu - Abú Sajjáf a tzv. skupiny Maute. $K$ prestřelce došlo $v$ souvislosti se snahou policie a zatčení nejvyššího představitele

14 Abú Sajjáf byla na seznam zahraničních teroristických organizací ministerstva zahraničí USA zařazena dne 10. 8. 1997 (podle: Foreign Terrorist Organizations [online]. Washington, D. C.: U. S. Department of State [cit. 2019-03-14]. Dostupné z: https://www.state.gov/j/ct/rls/other/des/123085.htm).

15 Abú Sajjáf v překladu znamená „otec šavle“ - pozn. autora.

16 Abu Sayyaf Group. Mapping Militant Organisations. [online]. Stanford: Stanford University. 20. 7. 2015. [cit. 2019-03-20]. Dostupné z: https://web.stanford.edu/group/mappingmilitants/cgi-bin/groups/view/152.

17 Asia Threat Overview. Special Warfare. Fort Bragg: U. S. Army John F. Kennedy Special Warfare Center and School. 2017, 30 (4), 96 s., s. 11-14.

18 REY, Aika. Fast Facts: Marawi City. Rappler [online]. Pasig: Rappler Holdings Corporation, 29. 7. 2017. [cit. 2019-03-26]. Dostupné z: https://www.rappler.com/newsbreak/iq/171246-fast-facts-marawi-city. 
samozvaně deklarovaného Islámského státu na Filipínách Isnilona Hapilona ${ }^{19}$. Útok bezpečnostních sil přiměl islamisty stáhnout se do vnitřních částí města a učinit prohlášení, kterým Marawi vyhlásili novým vilájetem Islámského státu. Militanti vypálili křestanský kostel, věznici a dvě školy předtím, než obsadili hlavní ulice a mosty ve městě. Křest́anští kněží a civilní obyvatelé byli vzati jako rukojmí, jeden policista byl st'at. V reakci na události večer téhož dne vyhlásil filipínský prezident Rodrigo Duterte stanné právo na celém ostrově Mindanao. Předpokládalo se, že bitva bude ukončena nejdéle do několika týdnů. ${ }^{20}$

\subsection{Maute Group na scéně}

Mimo bojovníků Abú Sajjáf se na obsazení města podíleli islamisté tzv. skupiny Maute. Tato radikální militantní frakce byla tvořena guerillovými bojovníky, kteří se odštěpili od MILF a jejichž velitelem se stal Omar Maute. Skupina je pojmenovaná po rodinném klanu Maute, který je na jižních Filipínách znám pro klasický mafiánský způsob podnikání, od legálních aktivit ve stavebnictví až po tradiční činnosti organizovaného zločinu jako obchodu s drogami, zbraněmi a vraždami na objednávku. Bratři Omar a Abdullah působili jako asistenti malajsijských seniorních lídrů organizace Jemaah Islamiyah na problematiku financování a vedení operací a tvořili spojovací článek mezi malajsijským vedením a filipínskými bojovníky. Bratři Mautovi měli příbuzné ve městě Marawi, z nichž někteří studovali v Jordánsku a zemích Zálivu. Omar a Abdullah ve své činnosti využívali reputace dané pobytem a vazbami získanými v zahraničí. Jiní bratři Mautovi působili jako nižší velitelé islamistických bojůvek. Na Filipínách šiřili představu Jemaah Islamiyah o ustavení chalifátu na Mindanau, přičemž jeho další územní části měly být v Malajsii a Indonésii. Částečnou motivací jejich boje byl separatismus, postupem času však stále více ovlivňovaný islamistickou ideologií. ${ }^{21}$

\subsection{Společný zájem Abú Sajjáf a Maute Group}

Od roku 2011 začal ideologický a operační vliv Islámského státu na Filipínách významně narůstat. Abú Sajjáf se rozdělila na dvě skupiny. První vedená Radullahem Sahironem

19 Isnilon Totoni Haploin, též znám pod bojovným jménem Abu Abdullah al-Filipini, nar. 1968, se postupně angažoval v rámci MNLF, Abú Sajjáf, al-Kájdě a Islámském státě na Filipínách. (Ref. ALIPALA, Julie. FBI called out on fake Hapilon news. Inquirer.net [online]. Manila: Philippine Daily Inquirer. [cit. 2019-03-26]. Dostupné z: https://newsinfo.inquirer.net/901505/fbi-called-out-on-fake-hapilon-news).

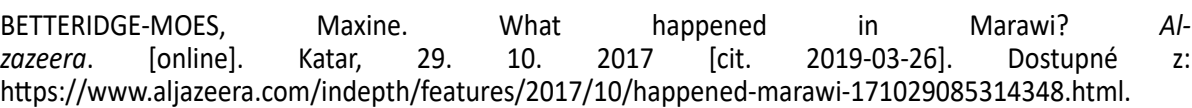

21 Rozhovor autora vedený dne 19.11. 2018 s důstojníkem filipínské zpravodajské služby působícím v oblasti boje proti terorismu v oblasti Mindanao. 
působila na Suluském souostroví, druhá vedená Isnilonem Hapilonem vyvíjela aktivity $v$ provincii Basilan na stejnojmenném ostrově. ${ }^{22}$

Basilanská skupina deklarovala věrnost vůdci Islámskému státu Abú Bark al-Bagdádímu, který jí přislíbil, že ji bude podporovat v úsilí zř́zení vilájetu ${ }^{23} v$ jihovýchodní Asii s hlavním městě na Mindanau. Bagdádí uložil Hapilonovi čtyři úkoly, které musí být splněny pro to, aby mohl být vilájet zř́zen:

- na veřejnosti projevit věrnost Islámskému státu;

- vytvořit bojovou skupinu;

- připravit operační plán činnosti této skupiny na Filipínách;

- disponovat územím pod vlastní kontrolou. ${ }^{24}$

První tři úkoly byly Hapilonem splněny, avšak oblasti Basilan a Sulu byly vyhodnoceny jako snadno ohrozitelné vládními jednotkami a jako takové nevhodné $v$ roli kontrolovaného, tedy bezpečného území. Hapilon proto inicioval schůzku představitelů separatistických muslimských organizací MNLF, MILF, Abú Sajjáf a Maute. Té se zúčastnilo okolo 300 militantů (za samotnou Abú Sajjáf okolo 20 bojovníků) a bylo na ní dohodnuto, že hlavním městem zamýšleného chalifátu bude město Butig ${ }^{25} v$ provincii Lanao del Sur. Filipínské bezpečnostní složky se však o setkání islamistů dozvěděly a zaútočily. Při využití dělostřeleckého ostřelování, leteckých úderů a nasazením př́slušníků speciálních sil ze $1^{\text {st }}$ Scout Ranger Regiment se jim podařilo zlikvidovat okolo 90 militantů. Po této úspěšné armádní operaci se asi 20 bojovníků Abú Sajjáf a okolo 80 členů Maute Group uchýlilo do Marawi, kde spoléhali na výjimečné postavení rodiny Mauteových v místní muslimské komunitě. $V$ této situaci je zastihla bezpečnostní akce filipínských sil 23. 5. 2017 usilujících o Hapilonovo zatčení. ${ }^{26}$

\subsection{Průběh bojů o Marawi}

Tvrdý odpor militantů a nepřipravenost bezpečnostních složek umožnila islamistům obsazení města a opevnit se v něm. Později byly nalezeny důkazy o tom, že ve městě byly na mnoha místech ukryty zbraně a zásoby a obsazení města bylo oběma skupinami dlouhodobě plánováno. Ačkoli filipínský ministr obrany prohlásil, že město bude od teroristů osvobozeno v rádu týdnů, tak ve skutečnosti se bojové operace protáhly na celých pět

22 Ibid.

23 Vilájet - administrativní jednotka chalifátu vycházející z dřívějšího členění Osmanské řiše (pozn. autora).

24 Ref. 21.

25 Město je známé tradicí muslimského ozbrojeného odporu proti španělským a americkým kolonizátorům. V únoru 2016 zde vedla filipínská armáda boje s Maute Group, která v listopadu 2016 město obsadila, ale po týdnu bojů byla z pozic vyhnána (Ref. ROMERO, Alexis. 3 soldiers killed, 11 hurt in Lanao del Sur clash. PhilStar Global. [online]. Manila: The Philippine Star, 26. 2. 2016. [cit. 2019-03-26]. Dostupné z: https://www.philstar.com/nation/2016/02/26/1557058/3-soldiers-killed-11-hurt-lanao-del-sur-clash).

26 Rozhovor autora vedený dne 19. 11. 2018 s důstojníkem filipínské zpravodajské služby působícím v oblasti boje proti terorismu v oblasti Mindanao. 
měsíců. Prvotní optimismus ministra nebyl v zásadě neoprávněný, jelikož již za několik dnů ozbrojené síly opět kontrolovaly 90 procent rozlohy města, včetně části městského centra a dvou strategicky důležitých mostů. Zatímco západní část města byla zpět pod vládní kontrolou, tak $\mathrm{k}$ nejtěžším bojům se teprve schylovalo. Odehrávaly se v hustě zastavěných městských částech, kdy filipínská armáda stála proti několika desítkám zkušených a ideologicky zapálených militantů. ${ }^{27}$ Filipínské síly navíc nebyly nejen vycvičeny, ale ani adekvátně vybaveny pro intenzivní a dlouhotrvající boje vedené v komplikovaném urbanizovaném prostředí. ${ }^{28}$

Odpor islamistů byl natolik prudký a pro armádní síly neočekávaný, že vláda vyslala do města další posily a 25. 5. 2017 zahájila letecké údery proti pozicím povstalců. Odlehčily sice nasazeným vojákům, ale zoufalým způsobem začaly pustošit městskou zástavbu. Armádní složky trpěly chaosem, který se odrazil v několika případech tzv. přátelské palby, včetně incidentu 31. 5. 2017, při kterém přišlo o život 11 filipínských vojáků. ${ }^{29}$ Jelikož ani po týdnech bojů nedocházelo k finálnímu řešení situace, oznámily USA, že se zapojí do vedení bojových aktivit poskytnutím technické pomoci filipínské armádě, včetně průzkumných letounů. Později bylo potvrzeno, že příslušníci amerických ozbrojených sil byli ve městě fyzicky př́tomni, pouze se prímo nezapojovali do bojü. ${ }^{30}$

Dne 16. 6. 2017 došlo k incidentu, při kterém islamisté vypálili raketu, která zničila armádní obrněné vozidlo překračující most, a odstřelovač poté likvidoval ustupující vojáky. Následující 14 hodinová bitva si vyžádala životy 13 vojáků a přes 40 jich bylo zraněno. Navzdory událostem obdobného charakteru však docházelo k pokroku. Do poloviny června bylo údajně osvobozeno 80 \% území města. Údaj byl sice vládními představiteli prezentován již dřive a navíc $v$ této době byl zčásti nadhodnocený, nicméně pozitivní vývoj byl nezpochybnitelný. Na konci června se do operace zapojila Austrálie, která poskytovala vzdušný průzkum. ${ }^{31}$

Nezanedbatelné ztráty vládním silám působili povstalečtí ostřelovači vycvičení v Malajsii, kde již dřive militanti procházeli soustředěným výcvikem v provádění diverzních akcí a dalších aktivitách, způsobující ekonomickou a bezpečnostní nestabilitu na Mindanau. ${ }^{32}$ Rebelové též uplatňovali taktiku, kterou poznali v bojích v Iráku a Sýrii. Především se jednalo o nástražná výbušná zařízení (IED), kterých bylo později v Marawi vládními jednotkami nalezeno okolo 1500 . Byly konstruovány z klasických výbušnin nebo byly použity komponenty zařízení k ohňostrojům. Nástražná zařízení umist́ovali v okenních rámech a ve dveřích a odpalovali pomocí tlakových destiček, mobilními telefony nebo

27 Armádní zdroje později uvedly, že společně se zahraničními bojovníky se bitvy zúčastnilo okolo 1000 islamistů, nicméně toto číslo není ověřitelné a v kontextu celé situace se může jevit jako nadsazené - pozn. autora.

28 POSTINGS, Robert. The Battle of Marawi: A Brief Summary. [online]. International Review. 24. 12. 2017. [cit. 2019-03-27]. Dostupné z: https://international-review.org/battle-marawi-brief-summary/.

29 Ibid.

30 lbid.

31 Ibid.

32 Rozhovor autora vedený dne 19. 11. 2018 s důstojníkem filipínské zpravodajské služby působícím v oblasti boje proti terorismu v oblasti Mindanao. 
iniciačními kabely. Navzdory očekávání se filipínští vojáci nesetkali s tím, že by povstalci vybudovali pod městem tunely. Na druhé straně stejně jako v Iráku používali malé bezpilotní letouny, kterými prováděli průzkum postavení vládních jednotek, a sedm takových zařízení armáda sestřelila. ${ }^{33}$

V měsících červenci a srpnu 2017 pokračovaly boje o město. $V$ bojích se nezkušená filipínská armáda začala etablovat a získávat převahu. Na konci srpna byli radikálové vytlačeni z více než 400 budov v hustě obydlené a zastavěné části města. Až na konci září byly znovuzískány všechny zbylé mosty a byla započata finální ofenziva proti zbytkům militantů. Armáda zatlačila povstalce do několika posledních jimi ovládaných bloků v centrální části Marawi. Rychlost dosažení úspěchu vládních sil byla omezována lidskými štíty, které teroristé vytvořili z místních obyvatel, kteří již dříve neutekli mimo oblast bojů. Tato taktika výrazně omezila použití vzdušných sil k podpoře postupu armádních jednotek. Klíčovým momentem v závěrečné fázi bojů bylo zabití dvou vůdců rebelů dne 16. 10. 2017 př́slušníky speciálních sil filipínské armády a zvláštními jednotkami filipínské policie. ${ }^{34}$ Omar Maute byl zabit jednou ranou ostřelovače, Isnilon Hapilon byl usmrcen třemi střelami při pokusu o útěk z města. ${ }^{35}$ Následujícího dne prohlásil prezident Duterte, že Marawi bylo osvobozeno, i když k drobným přestřelkám v několika budovách docházelo ještě v následujícím týdnu. Těla 40 posledních vetřelcủ a jejich dvou manželek, účastnících se poslední fáze bitvy, byla nalezena v nejdéle obsazených budovách. Poslední černá vlajka Islámského státu byla stržena až 23. 10. 2017, tedy přesně po pěti měsících od vypuknutí prvního střetu. Boje stály životy více než 165 příslušníků filipínských bezpečnostních sil, nejméně 45 civilistů a asi 920 islamistů. ${ }^{36}$

\section{4 ÚČAST ZAHRANIČNÍCH BOJOVNÍKŮ}

Transnacionální charakter islamistických aktivit v Marawi potvrzuje prohlášení filipínského ministra obrany Delfina Lorenzany z června 2017, podle kterého byli mezi mrtvými teroristy identifikováni státní př́slušníci Saúdské Arábie, Čečenska, Jemenu, Indonésie a Malajsie. ${ }^{37}$ Někteři ze zahraničních džihádistů se pokoušeli na Mindanao dostat letecky, přičemž většina byla na letištích identifikována, zatčena a deportována. Bojovníci, kteří

33 ROBSON, Seth. Philippine troops credit US intel, training for helping them beat ISIS in Marawi. Stars and Stripes. [online]. Washington, D.C.: National Press Club, 9. 11. 2017. [cit. 201904-09]. Dostupné z: https://www.stripes.com/news/pacific/philippine-troops-credit-usintel-training-for-helping-them-beat-isis-in-marawi-1.496965.

34 POSTINGS, Robert. The Battle of Marawi: A Brief Summary. [online]. International Review, 24. 12. 2017. [cit. 2019-03-27]. Dostupné z: https://international-review.org/battle-marawi-brief-summary/.

35 GALLARDO, Froilan. One bullet for Maute, three for Hapilon. MindaNews. [online]. Davao: Mindanao Institute of Journalism, 16. 10. 2017. [cit. 2019-03-27]. Dostupné z: https://www.mindanews.com/top-stories/2017/10/one-bullet-for-maute-three-for-hapilon/.

36 Ref. 20.

37 East Asian Strategic Review 2018. Tokio: National Institute for Defense Studies, 2018, 244 s., s. 125. ISBN 978-4-7890-1694-0. 
se postavili po bok Abú Sajjáf a Maute Group se na Filipíny dostali po moři z malajsijského státu Sabah na Borneu a z oblasti Manado na indonéském severním Sulawesi. Ve prospěch pašeráckých aktivit nabíraly na významu rodinné a klanové vazby mezi místním obyvatelstvem na obou stranách mořské hranice. ${ }^{38}$

Tranzit militantů se stala natolik signifikantním problémem, že dnem 19. 6. 2017 zavedly Filipíny, Indonésie a Malajsie trilaterální námořní hlídkování. Dne 12. 10. 2017 začalo trilaterální vzdušné hlídkování nad oblastí Suluského moře, přičemž personál všech tři zemí byl př́tomen na palubách hlídkujících letounů. ${ }^{39}$

\section{ZAHRANIČNÍ VOJENSKÁ POMOC V PRŮBĚHU OPERACE}

V souvislosti s operací filipínských ozbrojených sil při obléhání Marawi získaly Filipíny poměrně četnou přímou pomoc od zemí v regionu. Od června 2017 prováděly USA technikou podporu filipínským speciálním silám a poskytovaly munici pro vzdušné údery. Od května poskytly průzkumné bezpilotní prostředky a letouny, současně vyslaly námořní hlídkový letoun Lockheed P-3 Orion ve verzi P-3C. V září USA oznámily zapojení bezpilotního letounu MQ-1C Gray Eagle. V červnu též Austrálie poskytla dva hlídkové letouny Orion ve variantě $P-3 C$ s účastí filipínského personálu na palubě. V červenci oznámil Singapur plán na zapojení svého letounu P-3 Orion, poskytnutí průzkumných dronů a výcvik filipínských sil pro boj v urbanizovaném prostředí ve svých výcvikových zařízeních. ${ }^{40}$

\section{NEDOSTATKY VLÁDNÍCH SIL}

Na první pohled rutinní víceméně policejní akce cílená na zadržení ustanovených vůdců islamistických separatistů se předchozí přípravou militantů na ozbrojený střet, jejich zkušenostmi a odhodláním změnila $v$ několikaměsíční intenzivní bojové akce vládních jednotek v silně urbanizovaném prostředí. Podmínky utvářející prostředí bojiště odhalily nedostatky ve velení, organizaci, koordinaci a technickém a technologickém vybavení filipínských ozbrojených sil.

Před změnami, ke kterým došlo na základě bojů o Marawi, byla např́klad koordinace činnosti speciálních sil prováděna armádním velitelstvím speciálních operací (Special Operations Command, SOCOM) jen u zvláštních jednotek pozemních sil. Speciální síly byly dislokovány pouze v tzv. kritických oblastech. Pluk Scout Ranger (Scout Ranger

38 YUSA, Zam. Malaysia and Indonesia foreign fighter transit routes to Philippines identified. The Defense Post [online]. Washington, D.C., 20. 11. 2018 [cit. 2019-03-28]. Dostupné z: https://thedefensepost.com/2018/11/20/malaysia-indonesia-philippines-foreign-fighters-transit-routes/

39 East Asian Strategic Review 2018. Tokio: National Institute for Defense Studies, 2018, 244 s., s. 114. ISBN 978-4-7890-1694-0.

40 Ibid, s. 126. 
Regiment) byl primárně nasazen proti islamistům skupiny Abú Sajjáf, pluk armádních Special Forces (Special Forces Regiment, někdy též přezdívaný filipínské Zelené barety podle rozhodujícího vlivu amerických Green Berets na výcvik filipínské jednotky) se soustředil na boj proti militantním komunistických bojůvkám. Armádní Light Reaction Regiment neměl jasně vymezeného stálého protivníka a byl nasazován podle potřeby, přičemž charakter operací odpovídal operacím americké Delta Force, která je hlavním výcvikovým partnerem filipínského pluku. Uvedenému zařazení na určitý typ protivníka též odpovídal způsob výcviku, výstroje a výzbroje, kterým jednotky filipínských speciálních sil disponovaly. ${ }^{\mathbf{4 1}}$

Nedostatek koordinace nasazených vládních sil byl zásadním nedostatkem ve směřování hlavního úsilí. V návaznosti na zjištěnou nutnost vyšší míry koordinace jak samotné bojové činnosti, tak př́pravy bylo rozhodnuto vytvořit k 6. 4. 2018 novou organizaci velitelství speciálních operací (AFP SOCOM), kterému jsou podřízeny všechny filipínské jednotky zvláštního určení. Oproti předchozímu SOCOM jsou nově vytvořenému velitelství podřízeny nejen Scout Ranger Regiment, vzdušně-výsadkový Special Forces Regiment, Light Reaction Regiment, ale ze struktury námořnictva Naval Special Operations Group (filipínská obdoba US Navy SEAL), z námořní pěchoty Marine Special Operations Group a od vzdušných sil $710^{\text {th }}$ Special Operations Wing. ${ }^{42}$

Nově vytvořené velitelství AFP SOCOM je odpovědné za plánování, vedení a podporu speciálních operací ve všech typech operačního prostředí a za podporu misí filipínských ozbrojených sil jako celku. Spektrum úkolů jednotek podřizených AFP SOCOM je velmi široké a z pohledu výcviku a nutného vybavení představuje vcelku ambiciózní projekt:

- prímá akce,

- zvláštní průzkum (za nepřátelskými liniemi),

- národní a mezinárodní protiteroristické operace,

- podpora zahraničního odporu nebo povstání proti vládě,

- osvobozování rukojmí,

- sabotáže,

- akce proti proliferaci, včetně zbraní hromadného ničení,

- protidrogové operace,

- údery proti cílům vysoké hodnoty (High-Value Target). ${ }^{43}$

Marawi přineslo novou zkušenost spočívající v uzavření oblasti a evakuaci civilistů. Rozhodující poznání však bylo dáno dosud nebývalým rozsahem dlouhotrvající operace v urbanizovaném prostředí, ve kterém nebyly filipínské síly schopny uplatnit celkový koncept konvenčního boje, pro který byly celá desetiletí americkými instruktory cvičeny. Ukázalo se, že výcvikové aktivity vedení konvenčního konfliktu nejsou beze zbytku

41 Rozhovor autora vedený dne 19.11. 2018 s důstojníkem filipínské zpravodajské služby působícím v oblasti boje proti terorismu v oblasti Mindanao.

42 PARAMESWARAN, Prashanth. What's in the New Philippines Special Operations Command? The Diplomat. [online]. Tokio: Trans-Asia. 13. 4. 2018. [cit. 2019-04-08]. Dostupné z: https://thediplomat.com/2018/04/whats-in-the-new-philippines-special-operations-command/.

43 Ref. 41. 
využitelné a výcvik bude nutno orientovat na přípravu vedení bojových aktivit s protivníkem, který zdatně využívá guerillových forem boje, nezřídka se silnou podporou místního obyvatelstva. ${ }^{44}$ Zajímavým aspektem prístupu filipínského nejvyššího vojenské velení bylo, že již v průběhu trvání bojů vyslalo do Marawi instruktory výcviku a doktrinální odborníky, aby jako pozorovatelé na místě dokázali identifikovat nedostatky ve vedení bojových aktivit vládními silami tak, aby je později zapracovali do doktrín operací obdobného charakteru a prípravy obsahu a forem výcviku. ${ }^{45}$

Další oblastí, ve které byly zjištěny nedostatky byla zpravodajská podpora. Spolupráce na uspokojivé úrovni probíhala mezi národní zastřešující zpravodajskou službou (National Intelligence Coordinating Agency, NICA), zpravodajskou složkou filipínské policie (Philippine National Police Intelligence Group) a vojenskou zpravodajskou službou (Military Intelligence Group, MIG), což se projevovalo především v oblasti zpravodajství z lidských zdrojů (Human Intelligence, HUMINT). Zcela odlišné a neuspokojivé výsledky byly zjištěny při hodnocení činnosti různých druhů technických prostředků průzkumu, na které upozornil ve svém vystoupení

ministr obrany Delfin Lorenzana na Národní škole obrany v polovině dubna 2018. Ačkoli odmítl specifikovat výši výdajů, které bude muset filipínská vláda vynaložit na odstranění nedostatků, je evidentní, že se jedná o oblast technického a technologického vybavení. Výslovně pak bylo uvedeno, že akviziční priority budou představovány technologiemi rozpoznávání obličeje, bezpilotními prostředky s delším doletem a dalším technologickým vybavením, které bude svým charakterem kamerového systému implementováno až do úrovně obecní správy. Záměr zlepšení zpravodajských schopností byl sice deklarován již delší dobu (v celkovém kontextu zpravodajství, sledování a průzkumu), avšak události v Marawi vytvořily prostor pro úpravu finančních priorit vlády $v$ rezortu obrany. ${ }^{46,47}$

V průběhu vedení taktických operací v Marawi byla zjištěna potřeba:

- rozsáhlejší vzdušné podpory, především nízko a pomalu letících letounů umožňujících užití přesné munice,

- rízených střel,

- bezpilotních průzkumných prostředků,

- těžkých útočných vrtulníků,

- presného dělostřelectva,

- těžkých tanků,

- komunikačního vybavení,

- ochranných prostředků jednotlivce, zejména balistických vest,

- obrněných člunů. ${ }^{48}$

\footnotetext{
44 Ref. 41.

45 Ref. 41.

46 PARAMESWARAN, Prashanth. Battle for Marawi Exposes Philippines' Military Intelligence Crisis. The Diplomat. [online]. Tokio: Trans-Asia, 16. 4. 2017. [cit. 2019-04-08]. Dostupné z: https://thediplomat.com/2017/08/battle-for-marawi-exposes-philippines-military-intelligence-crisis/.

47 Ref. 41.

48 Ref. 41.
} 
Zkušenosti z konfliktu v Marawi též iniciovaly změnu doktrinálního přístupu, který se nově mnohem více zaměřuje na vzdušnou podporu takového charakteru, která by omezila množství vlastních ztrát vládních sil vlivem nepřesného bombardování. Obdobně byla reflektována vhodnost pořízení těžších tanků určených k vedení operací v zastavěném prostoru, na rozdíl od současně využívaných lehkých tanků, vhodných k boji v džungli. Doktrinální změny zohledňují potřebu společných cvičení jednotek různých druhů filipínských ozbrojených sil zaměřených na jejich koordinaci na taktické úrovni, vedoucí $\mathrm{k}$ mnohem efektivnějšímu nasazení dosud téměř výlučně autonomně působících součástí. ${ }^{49}$

\section{ZÁVĚR}

Panislámský charakter působení Islámského státu, přitažlivost extrémní formy sunnitské ideologie a šíření zkušeností z bojiště na Blízkém východě postupně proměnily islamistickou scénu v prostoru jihovýchodní Asie. Teroristickým aktivitám pod praporem jednotící ideologie čelí bezpečnostní složky Thajska, Indonésie, Malajsie a Filipín. S postupnou vojenskou porážkou blízkovýchodních bojůvek Islámského státu se džihádisté přesouvají do početně významné muslimské části světa, aby zde rozvinuli praktické dovednosti ve střetu s regulérními silami a vytvářejí tak novou dimenzi dosavadního většinou etnického a regionálního konfliktu.

Ozbrojené síly států, které se ve větší či menší míře podílejí na protiteroristických aktivitách v Afghánistánu, Iráku, Sýrii či subsaharské Africe dokáží poměrně flexibilně implementovat do svého výcviku a doktrín nové zkušenosti, které na tomto poli získaly. Odlišně je tomu u armád, které neparticipují na bojových operacích protiteroristické koalice a nedisponují těmito zkušenostmi. Ačkoli islamisté působící na jejich vlastním území proměňují taktické způsoby vedení paramilitárních aktivit, vládní složky vycházejí $z$ dosud převažujících forem střetů.

Realita se plně ukázala právě v případě bitvy o Marawi, kdy filipínské ozbrojené síly a bezpečnostní složky nebyly připraveny v celé řadě dovedností, scházela jim schopnost koordinovat bojovou činnost různých druhů sil v silně zastaveném prostředí a projevily se omezené kapacity $v$ technickém a technologickém vybavení, především v oblasti zpravodajského zabezpečení.

Koncentrovaným úsilím a časovým rámcem byly boje o Marawi největší vojenskou operací, kterou filipínské síly na svém území vedly od skončení druhé světové války. Jejich charakter jasně poukázal na nedostatky, které bude muset nejvyšší filipínské vojenské velení odstranit. S ohledem na samotnou nepřehlédnutelnou př́tomnost fenoménu islamistické hrozby v regionu a předpoklad jeho přetrvávání v dlouhodobější perspektivě po vojenské porážce Islámského státu na Blízkém východě se jedná o problém, který bude ovlivňovat nejen vnitřní bezpečnost a ekonomickou stabilitu filipínského souostroví, ale též jeho mezinárodněpolitické postavení. Významným signálem může být mezinárodní

49 Ref. 41. 
vojenská pomoc, zejména při leteckých operacích poskytnutá ze strany USA, Austrálie a Singapuru. Na jedné straně ukázala odhodlání vlád zemí v regionu čelit přeshraniční hrozbě a na druhé straně potvrdila pragmatický přistup $\mathrm{k}$ formování tradičních politicko-vojenských spojenectví.

Autor: $\quad$ Plukovník gšt. Mgr. Ing. Libor Kutěj, Ph.D., narozen 1967. Od roku 1992 pracuje ve státobezpečnostních složkách, nejprve v rámci Ministerstva vnitra, a od roku 1996 Ministerstva obrany v Praze. V letech 2009 - 2012 püsobil ve funkci prídělence obrany Velvyslanectví ČR $v$ Izraeli. $V$ období let 2012 - 2015 zastával funkci ředitele odboru vojenské diplomacie. $V$ letech 2015 - 2019 vykonával funkci pridělence obrany Velvyslanectví ČR v Jordánsku. Od 1. 2. 2019 je vedoucím Katedry zpravodajského zabezpečení Fakulty vojenského leadershipu Univerzity obrany v Brně. V přednáškové a publikační činnosti se zaměřuje na zpravodajskou problematiku a politicko-vojenské a bezpečnostní souvislosti $v$ regionech Blízkého východu a východní a jihovýchodní Asie.

Jak citovat: KUTĚJ Libor. Obléhání Marawi, impulz změnit schopnosti filipínských ozbrojených sil. Vojenské rozhledy. 2019, 28 (3), 041-054. ISSN 1210-3292 (print), 2336-2995 (on-line). Available at: www.vojenskerozhledy.cz. 


\section{The Importance of the Zrínyi 2026 Defence and Military Development Program}

\section{Význam programu rozvoje mad’arských ozbrojených sil Zrínyi 2026}

\section{Olivér Balogh}

Abstract: The present article expresses the importance of the Zrínyi 2026 Hungarian government medium-term modernization program and its impact on military security in the region. Migration crisis, hybrid warfare treatments and withdrawal from the INF (Intermediate-Range Nuclear Forces) treaty were the main reasons for the enactment of the Zrínyi 2026 program. Comparing the Polish and Hungarian Defence Forces, the article analyses the significance of military security in Central Europe. The analysis explores organizational and legal changes and the purchase of armaments. The Hungarian program's objectives are to change not only the equipment but also the structure and organization. The Commander of the Hungarian Defence Forces was separated from the Ministry of Defence. The Hungarian program has declared the increase in the number of reserve forces to twenty thousand and the active duty personnel to roughly thirty-eight thousand.

Abstrakt: Článek pojednává o významu střednědobého modernizačního programu mad'arské vlády Zrínyi 2026 a jeho dopadu na vojenskou bezpečnost v regionu. Hlavními důvody pro přijetí programu Zrínyi 2026 jsou migrační krize, hrozby hybridní války a odstoupení od smlouvy INF (Smlouva o likvidaci raket středního a kratšího doletu). Na základě srovnání polských a mad’arských obranných sil analyzuje článek význam vojenské bezpečnosti ve střední Evropě. Analýza se zabývá organizačními a právní změnami a nákupem výzbroje. Cílem mad’arského programu je změnit nejen vybavení, ale i strukturu a organizaci. Velitel mad’arských obranných sil byl oddělen od ministerstva obrany. Mad’arský program deklaruje zvýšení počtu rezervních sil na dvacet tisíc a počtu personálu v aktivní službě přibližně na třicet osm tisíc.

Keywords: $\quad$ Defence Forces; Hungary; Poland; Security; Transformation; Zrínyi 2026.

Klíčová slova: Obranné síly; Mad’arsko; Polsko; bezpečnost; transformace; Zrínyi 2026. 


\section{INTRODUCTION}

The economic crisis and the transition of national economies from centrally planned to the free-market economies have caused a medium-term collapse and crisis of the military system in the Central European countries. The number of military personnel was decreased drastically and the military security role in the security policy was underestimated. Due to the Ukrainian-Russian conflict and the migration crisis the politicians of Poland, the Czech Republic, Slovakia and Hungary have realized that their countries should increase their military capabilities. From the Hungarian side, the Zrínyi 2026 Hungarian government medium-term military modernization program tried to seek an answer to the above-mentioned situation.

The modernization of the armed forces in most of the Central European countries started earlier than in Hungary, see, for example, the Polish modernization program for 2013-2022. There is a difference between the two programs in their nature. The Hungarian program's objectives are to change not only the equipment but also the structure and organization of the armed forces to increase their capabilities. In order to demonstrate the importance of the Hungarian program, the study will compare the changes in these two countries and their role for the meaning of military security.

\section{REASONS FOR STARTING THE MODERNIZATION PROGRAM}

In the period after 2007, the economic crisis led to a decreased importance of military security in the world. The European countries - following the Russian-Georgian war, the civil wars in the Middle-East and in eastern Ukraine - realized that they could prevent an external aggression and NATO would not help them if they did not start to develop their military forces and play a bigger role by increasing their defence budgets. The first step was the Wales Summit in 2014 when the NATO countries declared to increase their military expenditures to $2 \%$ GDP. ${ }^{1}$ The Central European countries had to consider further military measures.

For Hungary, the migration crisis and the situation in Ukraine - described as a hybrid warfare treatment - were the main reasons to launch the Zrínyi 2026 program. The crisis which was caused by a huge number of migrants trying to enter Europe showed that the Hungarian Police forces ${ }^{2}$ were unable to handle the situation and maintain the security. By the novelization of the armed forces' law, the Hungarian Government broadened the competences of the armed forces and assigned them the tasks of defending the border

1 NATO. Summit Guide. (On line). Brussels 2018. p. 310. Access date 09.04.2019. Available at https://www. nato.int/nato_static_fl2014/assets/pdf/pdf_2018_07/20180718_180711-summit-guide-brussels.pdf

2 In 2008, the Border Guard as a separate service was dissolved and its competences were handed over to the Police. 
in the event that the forces and means of security services are inadequate to maintain security and public order.

The biggest strike for Europe was the decision of US President Trump and Secretary of State Mike Pompeo, that the United States will suspend its obligations under the INF (Intermediate-Range Nuclear Forces) Treaty and the formal declaration of withdrawal from the treaty ${ }^{3}$ as well. The answer of the Russian Federation was the same which could mean a present-day arms race in the $21^{\text {st }}$ century. The meaning of this decision will change the attitude of European countries to security. Most of the security researches agree that this treaty was the biggest step to end the Cold War. It should be assumed that the withdrawal from this treaty will change the attitude of military security and long-term armament in Europe.

\section{THE POLISH AND HUNGARIAN ARMED FORCES BEFORE 2016}

The Hungarian Armed Forces is a small army. Because of the lack of sea border Hungary has only two types of forces: land forces and air forces. The integration of the two happened on 1 January, 2007 when the Hungarian Defence Forces Joint Force Command was established. Until 2016, the biggest technical changes in Hungarian Defence Forces occurred by phasing out the Mig-29 aircrafts from service and their replacement with JAS Gripen fighter aircrafts. There were some minor changes in the military equipment, yet not as important as the aircraft change in the air forces. The Hungarian Defence Forces military equipment was procured in the years of 1970-1990, such as the Mi-24 and $\mathrm{Mi}-17$ helicopters which needed renovation or replacement. The land forces are not capable to serve in international operations on a long scale, that is why only the contingents serving in foreign military operations had newer equipment whereas the homeland army kept using the Soviet and Russian technology. Even the aircraft capability was not able to serve the needs of the Hungarian army. In this case the An-26 transport aircraft was unable to transport the Hungarian contingents to Iraq and Afghanistan. Between 1991 and 2015, we could observe structural and organizational changes. The biggest change was the establishment of the Hungarian Defence Forces Joint Forces Command in Székesfehérvár. There were many programs and projects aimed at increasing the capabilities of military measures but most of the governments between 1991-2015 decided to cut the costs of upkeeping the armed forces. Most of the projects were not completed, the objectives were not sensible or had little significance for the military security of Hungary.

After the political changes, Poland was in the same situation as Hungary. They possessed a huge army and a lot of useless armament. The Polish Defence Forces (PDF) were in a better condition than the Hungarian Defence Forces, because Poland, as a central country between Germany and Russia, always had their military security in a central

3 Arms Control Association. (On line). (2012). Access date 09.04.2019. Available at https://www.armscontrol. org/ factsheets/INFtreaty 
place. After 2001 - the terrorist attacks against the WTC and Washington D.C. - Poland also realized that they should stop decreasing the military capabilities and that their armament was old and overused. In 2001-2013, they focused on buying the F-16 assault aircraft, production of Rosomak transport vehicles (AMV XC-360P from 2003) and SPIKE anti-tank rockets. The biggest success was the production of different types of Rosomak. It should be declared that the Polish Defence Forces have more possibilities than Hungarian Defence Forces because of the size of their country, which results in economic technical differences between the two countries. The numbers show that the participation of Polish contingents in Afghanistan and Iraq was much higher than of Hungarian ones. Between 2003-2008, more than 9000 soldiers served in the Polish contingent in Iraq. As a comparison, the Hungarian contingents had around 150 soldiers between 2004-2006. ${ }^{4}$

The biggest structural changes happened in 2013 when the command structure of the Polish Defence Forces changed. Under the new command structure, two commands were established: the Armed Forces General Command and the Armed Forces Operational Command. That means that the General Staff's competencies were decreased. The Operational Command's tasks were commanding the Polish contingents abroad and planning the use of armed forces in case of military and non-military crisis situations. The Armed Forces General Command's tasks were preparing and planning the Polish Defence Forces to defend the country and to ensure the security of citizens and support for international peace as a part of allied commitments.

In both, Hungary and Poland the command structures have been changed. Every change in the army structures means a long-term procedure to prepare the headquarters and make a new command structure. For defence forces it is the most important that each commander should know their competencies and tasks in case of war. That is why every change in command structure is decreasing the military readiness. It is estimated that after every change in the command structure the war readiness is achieved 4-5 years later.

\section{LEGAL AND STRUCTURAL CHANGES FROM 2016}

Analysing the Hungarian Law of Defence Forces, the biggest changes were made in 1990, when the democratic control of armed forces became the basis of defence forces. The new law from 1993 completely upset the socialist tradition and the 1973 law. Thanks to this amendment, the civil and democratic control of the armed forces were achieved. The new changes took place in 2004, when Hungary became a member of the European Union and we had to remember that in 1999 our country joined the NATO Alliance. In 2011, a new task was assigned among the defence forces competencies, namely, reaction in crisis situations (it had been a task of the army, but it was extended). In order to stop the influx of migrants and refugees into the country in 2015-2017, the amended Act

4 Földesi, F., Kiss, Z., Isaszegi, J. Quarter of the Hungarian Army (A Magyar Honvédség negyedszázada). Budapest 2016. p. 194. 
of Armed Forces extended the competencies of army to maintain the public order and defend the state border. The amendment has expanded the importance of internal functions - preserving national security. Significant structural and legal changes were made in this period. For instance, to support the police in cases when their forces and resources are insufficient, the Hungarian Defence Forces can support them - this was experienced at the borders of Hungary during the migration crisis.

In 2018, the Hungarian Defence Minister PhD Tibor Benkő - in 2010-2018, the Chief of General Staff of the Hungarian Defence Forces - submitted the proposal to change the command structure of the Hungarian Defence Forces. The changes came into force from the beginning of 2019 by the amendment of the Act of Armed Forces. The objective of the change was to integrate the command structure. A new position was established: the Commander of the Hungarian Defence Forces. By this alteration, the positions of the Chief of the General Staff and the Commander of Joint Forces became integrated. This means one-arm command structure in the military and a significant separation of this function from the Ministry of National Defence. Thanks to these legislative changes in the structure, the Ministry will manage the Hungarian Defence Forces and the Commander will command the defence forces. The Hungarian Defence Forces Command was established also in Székesfehérvár, where the Command of Joint Task Forces was renamed. The objective of these changes was also to relocate all the strategic headquarters from Budapest. ${ }^{5}$

Comparing to the Hungarian military command, the structure of the Polish one is more complicated. After the amendment (in December 2018) to the Law of Polish Defence Forces, the role of Chief of General Staff was strengthened and its competencies were extended. The Chief of General Staff became the first soldier with the Armed Forces General Command and the Armed Forces Operational Command subordinated to him. In case of war, the Chief of General Staff of the Polish Armed Forces will be the Commander until the Supreme Commander of the Polish Armed Forces will be nominated. According to the Defence Minister, Mr. Mariusz Błaszczak, the changes introduced in 2018 eliminated the competence chaos and established a one-man responsibility for the command. ${ }^{6}$ In 2016, the establishment of Territorial Defence Forces in Poland created the fifth military branch of the Polish Defence Forces. The aim of the new type of forces is to reach the size of fifty-three thousand personnel in 2021. The Territorial Defence Forces should cooperate with the operational forces and support the non-military system in crisis management. This force is under the governance of the Ministry of Defence and subordinated to the Commander of Territorial Defence Forces. It is planned that the Territorial Defence Forces will be subordinated to Voivodes - governmental representatives at the governor administration level.

5 Wolters Kluwer. Hungarian Defence Forces and Measures Taken During the Crisis States. (On line). 2011. CXIII. National Defence Act. §46-47. Access date 17.12.2018. Available at https://net.jogtar.hu/ jogszabaly?docid=A1100113.TV

6 Portalgov.pl. MoD. (On line). 2019. Access date 19.04.2019. Available at https://www.gov.pl/web/ obrona-narodowa/system-dowodzenia-w-wojsku-polskim-musi-byc-przejrzysty 
The Hungarian government, in order to support the participation in reserve services, has created a Territorial Defence Reserve System, similar to the Polish one. In October 2018, the number of reservists reached eight thousand. ${ }^{7}$ The plans are to increase the number of reservists to twenty thousand. From 1 January, 2017, the organizational framework of 197 district companies was established. „In the Volunteer Territorial Defence Reserve - which is the third element of the reserve system, besides the systems of Volunteer Defence Reserve and Volunteer Operational Reserve - training for the applicants is provided in the training companies, and a sports company has also been set up to support sporting activities. ${ }^{.8}$

\section{THE MILITARY POTENTIAL OF HUNGARY AND POLAND}

After the military policy changes the Hungarian government has been increasing the number of service personnel in defence forces. I have to emphasize that there is a difference between the legal and the real numbers of personnel. The Table 1 below describes the legal numbers resulting from two decisions of the Hungarian National Assembly.

Table 1: Anticipated composition of the Hungarian Defence Forces based on the Decisions of the National Assembly from 2013 and project from 2018

\begin{tabular}{|c|c|c|c|}
\hline Service positions & $\begin{array}{c}\text { Numbers by the } \\
\text { Decision from } \\
\mathbf{2 0 1 3}\end{array}$ & $\begin{array}{c}\text { Project of the new } \\
\text { Decision from 2018 }\end{array}$ & $\begin{array}{c}\text { Percentage of all official } \\
\text { positions in the Armed } \\
\text { Forces }\end{array}$ \\
\hline Officers & 5690 & 6600 & At most 33\% of all \\
\hline $\begin{array}{c}\text { Non- } \\
\text { commissioned } \\
\text { officers (NCO) }\end{array}$ & 8845 & 10200 & At most 30\% of all \\
\hline $\begin{array}{c}\text { Enlisted } \\
\text { personnel }\end{array}$ & 7895 & 13200 & - \\
\hline Cadets & 500 & 800 & At most 25\% of all \\
\hline NCO cadets & 100 & 250 & \\
\hline Civil personnel & 6670 & 6600 & \\
\hline All & 29700 & 37650 & \\
\hline
\end{tabular}

Based on: 35/2013 Decision of the National Assembly of 16 May, 2013 on the numbers and composition of the Hungarian Defence Forces, https://mkogy.jogtar.hu and the project, http://www.parlament.hu/irom41/02163/02163.pdf access date 18. 04. 2019

7 Zoltán, H. The new Territorial Defence Regiment has been established. (Megalakult az új területvédelmi ezred). (On line). 2018. Access date 19.04.2019. Available at http://www.kormanyhivatal.hu/hu/baranya/ hirek/megalakult-az-uj-teruletvedelmi-ezred

8 Végh, F. The Hungarian Armed Forces 1989-2017. (A Magyar Honvédség 1989-2017), (edit.) J. F. Holló, J. Isaszegi, L. Négyesi, A Magyar Honvédség 170 éve, Wyd. Zrínyi, Budapest 2018, ISBN 978-963-327-758-4, p. 337. 
Table 1 demonstrates that the legal number of serving personnel has been increased by eight thousand without changing the number of civil personnel. Of course, this number is the legal number established in legislative decisions but the real numerical status is lower. Hungary's population is around 9.7 million citizens. In case of war, around 2.2 million people shall serve in compulsory military service. In 2018, the age for compulsory military service was increased to 50 -year old people. ${ }^{9}$ Analysing the legal numbers of serving personnel by adding the planned number of reservists (twenty thousand), the defence forces will reach about fifty-seven thousand that would be $0.6 \%$ of the citizens of the country.

In Poland the numbers are more complicated. As far as the statistics are concerned, the numbers are as follows: around twenty thousand officers, around forty thousand non-commissioned officers, forty thousand enlisted personnel. In 2018, the personnel of the Polish Armed Forces with the Territorial Defence Forces totalled around one hundred and twenty thousand. According to the plans of the Polish Ministry of Defence, the number of military personnel should reach one hundred and fifty thousand by 2025 . Poland has about thirty-eight million inhabitants, which means that $0.3 \%$ of the citizens was serving in the armed forces in 2018 and in 2025 the rate will increase to $0.4 \%$.

Comparing the two planned numbers of military personnel, the Hungarian Defence Forces with the number of reservists will reach $0.6 \%$. That is $0.2 \%$ more than in the plans of the Polish Defence Forces. It means that when the plans are reached, Hungary will be statistically more militarized country than Poland.

The military potential is very difficult to define. For presenting it, military expenditures are one of the most reliable data. At the Wales Summit it was declared and at the Warsaw Summit in 2016 it was confirmed that NATO member countries should allocate $2 \%$ of their GDP on military expenditures. Poland has already reached it but Hungary is still below this figure. After the political reorientation in 2016, the military budget in Hungary started to increase drastically. According to governmental sources, in 2018, the Hungarian military budget has reached $1.4 \%$ GDP, ${ }^{10}$ but by the NATO statistics it is just $1.15 \%$ GDP. ${ }^{11}$ The Hungarian Ministry of Defence declared that Hungary can reach $2 \%$ GDP military expenditures by 2024 . Before the parliamentary elections in 2016 , the government planned to reach this figure only in 2026. Raising the defence expenditures will be a challenge for the national economy but according the statement of the Defence Minister and the economic growth figures, the $2 \%$ can be achieved in 2024-2026.

As the chart below shows, most NATO countries are below $2 \%$ and sometimes even under 1\% GDP military spend. Slovakia, the Czech Republic and Hungary's military budgets are around $1 \%$ of their GDP which means that these countries can expect huge changes if they want to develop their military potential. President Trump declared many

9 Data is from the Hungarian Central Statistical Office. (On line). 2011. Access date 19.04.2019. Available at http://www.ksh.hu/nepszamlalas/tablak_demografia

10 Figyelö 2019/16. Reportage with the Defence Minister. 2019. p. 12.

11 NATO. The Secretary General's Annual Report 2018. (On line). 2019. p. 126. Access date 19.04.2019. Available at https://www.nato.int/nato_static_fl2014/assets/pdf/pdf_publications/20190315_sgar2018en.pdf 
times that the USA would not defend those countries which did not invest in the military capabilities according the Alliance's needs. This year, it will show how the Alliance members will deal with this challenge and if their national economies are ready to increase their defence expenditures.

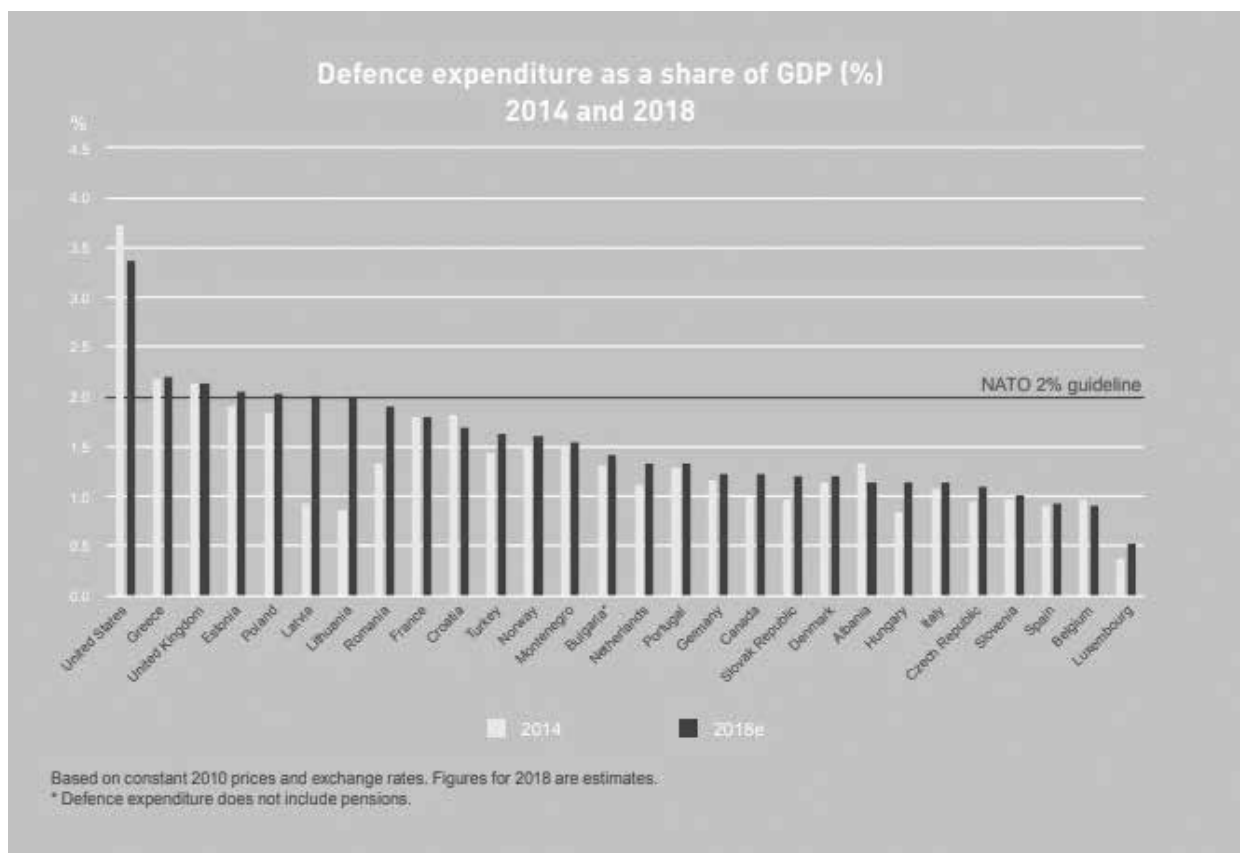

Figure 1: Defence expenditure as a share of GDP (\%) 2014 and 2018

Source: NATO The Secretary General's Annual Report 2018

\section{MILITARY SECURITY MEASURES IN CENTRAL EUROPE}

According to Barry Buzan, military threats can affect all the elements of the state. ${ }^{12}$ It follows from this that the basic objective of a state is to be capable of defending its inhabitants in the event of a military aggression. After the Cold War, the importance of military security was decreased and most of the countries which became members of the Alliance felt no threat from another countries. They underestimated the meaning of this kind of security. The level and objectives of military threats take on different level of impact. The fact that countries involve their armed forces puts this category to a special level, which has a huge impact on state security just when the military threat is being realized. „Military actions not only strike at the very essence of the state's basic protective functions but also threaten damage deep down through the layer of social and individual

12 Barry Buzan. People, States and Fear. Wheatsheaf Books LTD. 1983. p. 75. ISBN 0-7108-0101-7. 
interest which underline and are more permanent than the state's superstructures. ${ }^{\prime 13} \mathrm{It}$ must be underlined that every sector has an impact on each other but the consequences of losing military security are more drastic, which can cause death of a huge number of citizens. The military security is the highest priority in the national security policy. Without it, the country could lose its sovereignty and independence.

Military security has an important meaning in Central Europe because of the numbers of historical conflicts in the region. The wars in the Balkans at the end of the $20^{\text {th }}$ century showed that Europe cannot avoid wars in the continent. However, the EU membership of countries decreased the possibility of a military conflict in Europe, but conflicts of national, ethnical or religious nature are not avoided for sure. The southern border of Hungary will always be one of the most labile and the country should never allow such situations as happened at the end of the $20^{\text {th }}$ century. For Hungary and Poland, the Ukrainian civil war and crisis are among of the factors, which showed the governments that military measures are important for the countries. Hungary is a small country with limited capabilities but as the example of Switzerland shows, even a neutral country cannot be neutral in a military conflict when it does not have military forces to deter the enemy. Because of their geopolitical location, Poland and Hungary will never be neutral countries and the military measure is important to secure the countries' integrity and sovereignty.

According to Eric Herring, within the framework of the military security agenda the means can be divided into non-military means and military means that may have military objectives or non-military objectives. In order to present this theory, the table below was added to the article:

Table 2: Military security agenda

\begin{tabular}{|c|c|}
\hline $\begin{array}{c}\text { Military means, military objectives } \\
\text { for instance: military aggression to } \\
\text { occupy the neighbouring country }\end{array}$ & $\begin{array}{c}\text { Military means, non-military } \\
\text { objectives }\end{array}$ \\
\hline $\begin{array}{c}\text { Non-military means, military } \\
\text { objectives }\end{array}$ & $\begin{array}{c}\text { Non-military means, non-military } \\
\text { react to a crisis like flood }\end{array}$ \\
$\begin{array}{c}\text { objectives } \\
\text { for instance: economic sanctions to } \\
\text { weaken the military potential }\end{array}$ & $\begin{array}{c}\text { for instance: economic sanctions to } \\
\text { enforce human rights }\end{array}$ \\
\hline
\end{tabular}

Source: Péter Márton, István Balogh, Péter Rada. Biztonsági tanulmányok Új fogalmi keretek és tanulságok a visegrádi országok számára, Antall József Tudásközpont. Budapest 2015. p. 188. ISBN 978-615-80092-9-4.

As far as the recent military security of Hungary and Poland is concerned, the possible threat of military aggression with military objectives is very low. However, as the Yugoslavian wars and the Ukrainian civil war demonstrated, military conflicts can appear

13 Ibidem. 
near the border. The escalation of conflicts in other countries can cause escalation as it happened at the beginning of World War I in 1914. Nowadays, most of the elements forming the military security are non-military means but might possess military and non-military objectives. The military strategies declare that the other states are not enemies of Poland or Hungary. However, they indicate that the Russian policy could become a challenge for military security in the region. The possibility of a military crisis in Central Europe is small but should not be excluded completely.

The V4 countries, in order to demonstrate their power, have established the Visegrád EU Battle Group led by Poland. It was on standby from 1 January to 30 June $2016 .{ }^{14}$ The members included not only the V4 countries' soldiers but also a small group from the Ukrainian Defence Forces. The main combat forces were Polish ones, logistics forces, a helicopter unit, an electronic warfare team and a medical unit were made up of the Czech contingent, a combat engineer squad and a CIMIC unit were from Hungary and units for protection against weapons of $A B C$ were Slovak. This battle group is one of the examples of military cooperation in the area by the V4 countries. The EU battle group is planned to be on duty/standby from 1 July to 31 December this year (2019). It must be underlined that it has never been used up to now.

\section{ZRÍNYI 2026 MEDIUM-TERM MODERNIZATION PROGRAM}

The program was named after Miklós Zrínyi, a military leader, a poet and a statesman from the $17^{\text {th }}$ century. He was a member of a Hungarian-Croatian noble family. His great-grandfather was the heroic defender of Szigetvár in 1566. Miklós Zrínyi fought in Croatia against the Ottoman Empire's army, and thanks to his skills the Hungarian-Habsburg army stopped the Turkish expansion in 1664 . Honouring his military skills, his name was borne by the Military University in Budapest between 2000-2012 (and before that also by the Military College).

The program was adopted in 2016, and its main objective was to increase the Hungarian Defence Forces capabilities and establish a significant force in the region. In order to reach this main objective, a lot of goals were created. The Hungarian politicians discovered that without their domestically-produced technologies in the long term, Hungary is unable to grant the needs of the army. It can help not only to increase the national economy but also to decrease the time of supporting the armed forces. Domestic production may be more expensive than producing in a country with better capabilities and better experienced and qualified workers, but this also means capital emigration from the country. This goal has been introduced from the beginning of the program. First, the well-known lkarus factories started the production of buses for the defence forces. However, the factory was bankrupted after a few years of working. The opening

14 Defence policy. Visegrad EU Battlegroup Has Completed Duty. (Wyszechradzka Grupa Bojowa UE zakończyła dyżur). (On line). (2017). Access date 18.03.2018. Available at https://www.defence24.pl/ wyszehradzka-grupa-bojowa-ue-zakonczyla-dyzur 
of a new factory in Kiskunfélegyháza seems to be another successful step to revive the Hungarian military industry. This factory will produce small arms under Czech licenses, such as the CZ Scorpion EVO 3 submachine-gun, CZ P-09 pistol and CZ Bren 2 assault rifle. The real production will be started in the second half of 2019 but the assembling of previously produced parts has already been started there..$^{15}$ This cooperation started in 2018 and the production will be profitable for our country. After testing the firearms, the Hungarian military experts and personnel have classified these weapons as good quality armament.

Other goals have been described in detail in earlier sections of the article, that is why they will be only mentioned. Because of the launch of weapons race all over the world, the government has decided to increase the number of reservists to twenty thousand and the active duty personnel to roughly thirty-eight thousand. In order to reach this goal, the government started to create a new career model for soldiers not only by increasing their salary. The barracks and workplaces were renewed, the government provided extensive aids for soldiers. Additionally, the government started the recruitment on a huge scale in the country. The most important goal is to reach $2 \%$ GDP military expenditures by 2024. The program includes the modernization of the whole defence forces, not only the equipment but the uniforms have already been changed and there are plans to equip the soldiers with modern digital means. The goals also include the modernization of such military technical systems like radars, EW systems and CIS systems. The cyber defence is also emphasized in the program, but there is no exact information on the command structure and government plans. After the realization of these goals, the Hungarian Defence Forces should possess $21^{\text {st }}$ century up-to-date capabilities.

The first step to increase the Hungarian Defence Forces capabilities was the purchase of two Airbus A319 airplanes to replace the old and overused An-26. During the war in Afghanistan and Iraq, the An-26 aircraft was not capable of transporting the Hungarian contingent directly, it had to stop in Turkey and subsequently other countries' air forces transported our soldiers to those missions. That is why the purchase of new transport planes was an inevitable task for the new modernization program. A small plane was also purchased, namely a Dassault Falcon 7X, which is used for diplomatic missions. The use of military air transporters by politicians and diplomatic groups is also a means of military security. In case of crisis and conflict, first, the diplomatic measures should try to work on the solution, and military force should be used only if unavoidable. (Here we should mention that after the bankruptcy of MALÉV in 2012, Hungary lost its own air transport company.) This step showed to the Alliance and to the Hungarian society that this program wants to really increase the capabilities. Since 2019, the air forces will have 3 Airbus A319 and 2 Dassault Falcon 7X aircraft. ${ }^{16}$ In the meantime, the government has decided to renovate the Mi-17 and Mi-24 helicopters in the Russian Federation. All

15 Szabolcs N. New Weapons for Hungarian Soldiers. (On line). 2018. Access date 25.04.2019. Available at https://honvedelem.hu/cikk/113828_uj_fegyverek_a_magyar_katonaknak

16 A third Airbus and additional aircraft bought by the army. (Egy harmadik Airbust és további repülöket is vesz a honvédség). (2018). (On line). Access date 25.04.2019. Available at https://index.hu/ belfold/2018/12/11/egy_harmadik_airbust_es_tovabbi_repuloket_is_vesz_a_honvedseg/.Access date 25.04.2019 
the helicopters are ready to serve from 2019 to 2023-2024 when the new helicopters purchased from Airbus should arrive. The first contract with Airbus was the purchase of aircraft, followed by ordering 20 Airbus H135M helicopters for Special Forces. ${ }^{17}$ These helicopters will be used in crisis management and in scouting missions. The last contract which aims to increase the air force capabilities is the purchase of Airbus 225M multi-task helicopters. ${ }^{18}$ The contract was signed in December 2018 and these helicopters will be attached to the air forces in 2023. These multi-task helicopters will replace the old Soviet technologies. These new purchases mean not only new technologies for the Hungarian Defence Forces but also a huge amount of responsibility. The purchase is one of the steps, the pilots should undergo intensive training to learn to pilot the aircraft and helicopters. That is why achieving the military readiness of these new technologies will take certain time. The last element of air forces is the Saab JAS39 Gripen assault aircraft, leased by the Hungarian Defence Forces. In 2018, this aircraft has been modified and the contracts for lease were extended to 2026. This contract gives time to the government to make a decision if they will purchase the newer versions of Gripen or purchase F-35 as mentioned by the Defence Minister. Summarizing, the Hungarian Air Force capabilities and possibilities have been clearly increasing since the launch of the modernization program. Such kind of purchases has never been seen in the Hungarian military history since the political reorientations.

Because of the lack of sea border, there is no need for navy. Hungarian Defence Forces have a regiment of engineers and river guard. The basic tasks of these forces are to scout for bombs and explosives from World War II and deactivate them. The military potential of these forces is not significant, that is why this regiment is part of the land forces.

The capabilities of the land forces were below the NATO average standards. The equipment was from the second half of the $20^{\text {th }}$ century and was overused and old. The renovation of these vehicles and armaments is not profitable. The BTR-80 armoured vehicles, T-72 tanks and D-20 type $152 \mathrm{~mm}$ artillery were purchased during the Cold War and they are not suitable in a modern conflict. The first step was to change the wheeled vehicles including buses and cars for everyday usage and transport vehicles. As it has been mentioned before, most of this equipment was too old to be used nowadays. In the years 2016-2018, plenty of those types of vehicles were purchased and given to the army. To increase the special land forces' capabilities, some special equipment was purchased, such as Polaris MRZR 4 ultralight vehicles. The advantages of these cars are their high speed and manoeuvrability. Thanks to them the special forces are ready to serve not only in plain but also in difficult terrain. The next step for land forces is to increase

17 Honvedelem.HU Force Development continues - new military helicopters will be acquired by the Army. (Folytatódik a haderö fejlesztése - új katonai helikoptereket szerez be a honvédség). (On line). 2018. Access date 25.04.2019. Available at https:// honvedelem.hu/cikk/111144_folytatodik_a_hadero_fejlesztese_uj_katonai_ helikoptereket_szerez_be_a_honvedseg

18 Helicopters are expanding from 2023 to the Army's aerial fleet is moving on to the Force development. (Újabb helikopterekkel bővül 2023-tól a honvédség légiflottája Töretlenül halad a haderőfejlesztési). (On line). 2018. Access date 25.04.2019. Available at https://honvedelem.hu/ cikk/113884_ujabb_helikopterekkel_bovul_2023_tol_a_honvedseg_legiflottaja 
the land force firepower. It was a big surprise when, according to media sources, the Defence Minister announced the purchase of new tanks and artillery. The last months of 2018 were declared as one of the most eventful in the modern history of the Hungarian army. On the $19^{\text {th }}$ December, 2018, an agreement was signed with the Krauss-Maffrei Wegman Corporation on the purchase of 44 items of Leopard 2A7+ and 24 items of PzH 2000 self-propelled artillery. ${ }^{19}$ These two purchases should definitely increase the firepower. Leopard $2 \mathrm{~A} 7+$ is the newest version of one of the best tanks in the world. Leopard tanks possess not only huge firepower, but they are safe and technologically a miracle of the German armament. This agreement means that the newest versions will arrive in 2025 and will be part of the heavy division in Hungary which is planned to be established in 2028. Until that time, 10 Leopard 2A4 tanks will be leased to train the operators. ${ }^{20}$ Another purchase with the goal to increase the firepower was the that of Carl Gustav M4 anti-tank weapons. As the Ministry declared, the government is planning to buy the newest versions of armament which can increase the power of the defence forces. Thanks to these procurements, the Hungarian soldier becomes a real $21^{\text {st }}$ century soldier. Of course, there are still a lot of tasks waiting to be accomplished. The Hungarian air missile system is old and requires improvement. The purchase of American air missile systems in Romania - as an ally in NATO - could be enough to defend Hungary against missiles. However, without their own air missile system, none of the countries can reach a secure level of military security.

If comparing the Hungarian modernization program with the Polish plans we acknowledge that our Polish allies are planning to develop their armed forces similarly. In 2017, the Polish military modernization program for the years 2013-2022 was extended to 2026. It might be caused by the extension of new technologies purchases, the change of government and election to the Polish Parliament. This program includes 14 operational points on what tasks the Polish Defence Forces should face. In 2016, another point was added to develop the capabilities of cyber defence. We can declare that the objective of this program is to develop ground, air and navy forces so that soldiers can resist contemporary threats. There were many obstacles in the years, such as a denouement of the agreement on purchasing the Airbus H225M Caracal helicopters in 2015. Also, there have been problems with reaching an agreement with the US government about the purchase of air missile systems. The Ministry of Defence searched for other solutions which could replace these gaps in the program. This means that the Polish Armed Forces will receive the new multi-task helicopters only after 2022. The Polish ground forces already use Leopard tanks, but an older version than Hungary is planning to purchase. The Leopard 2A4 tanks from 1985-1986 - despite already having undergone a renovation process - should be renovated again shortly. This renovation is included in the modernization plan. Poland has T-72 and PT-91 Twardy (Tough) tanks. Some of

19 Portfolio. MTI buy new tanks in Hungary - so they might look. MTI, Új harckocsikat vesz Magyarország - így nézhetnek ki. (On line). 2018. Access date 25.04.2019. Available at https://www.portfolio.hu/vallalatok/ uj-harckocsikat-vesz-magyarorszag-igy-nezhetnek-ki.308333.html

20 Infostart. Report with the Defence Minister. (On line). 2018. Access date 23.04.2019. Available at https:// infostart.hu/belfold/2019/01/04/benko-tibor-elarulta-mi-mindent-vesz-a-honvedseg-2028-ig/amp 
them are planned to be renovated, the other part will be replaced by new purchases. In order to support the Polish military industry, Poland has been trying to renovate its military equipment in domestic companies. Thanks to domestic companies, Poland's biggest success was the modification of the AMV XC-360P armoured vehicles to the Rosomak type. As Brigadier General Adam Duda, PhD. in reserve concludes, the weakness of the program is its long-term planning and production. ${ }^{\mathbf{2 1}}$ Even if they are efficient in the field, they become old and require renovation.

Part of the Polish modernization program has been completed successfully, but as it is the case with Hungary, there are still a lot of things to do in the near future. Poland is also planning to increase their air force capabilities. Some of the Polish media sources announced that Poland would like to purchase Lockheed Martin F-35 Lightning stealth multirole fighters. These fighters are known as the newest generation of aircraft and could be an appropriate choice, of course, depending on the agreement. The newest aircraft requires new technologies. Buying this aircraft means - not just for Poland, but also for Hungary - a long-term agreement for spare parts and repair with Lockheed Martin Corporation.

\section{CONCLUSION}

With the analysis of the Hungarian and Polish modernization programs, the Central European countries' military security can be at least partly assessed. The home conflicts in border regions and the withdrawal from the Intermediate-Range Nuclear Forces Treaty - which can cause a $21^{\text {st }}$ century arms race - resulted in increasing the military measures. Some analyses have already mentioned these events as the start of a modern cold war with other bodies and means. That is why the above-mentioned changes in the structure and armament were inevitable in order to maintain the security of the two countries. The $2 \%$ GDP for military expenditures is a challenge for small countries like Hungary, but in the opinion of the Defence Minister, the country will reach this level in 2024 as it was declared during the Wales Summit.

After the political changes, the tendency of militarism and the number of active personnel was decreasing. The stagnation of the armed forces was stopped for a moment after the terrorist attacks on New York and Washington D.C. in 2001. The real turning point was the Russian clash in Georgia and the crisis in Ukraine. The Polish and Hungarian governments and commanders - from the lessons learned in Iraq and Afghanistan - understood that the two countries' defence forces had lacked military potential and capabilities. In response, Poland increased the air force and land force potential by purchasing F-16 s and launched the production of multi-functional transport vehicles,

21 Stratpoints. Gen. bryg. rez. Adam Duda. Assessment of the state of implementation of the SZ RP technical modernization plan for the years 2013-2022. Success or defeat? Ocena stanu realizacji planu modernizacji technicznej SZ RP na lata 2013-2022. Sukces czy porażka? (On line). (2013). Access date 23.04.2019. Available at https://www.stratpoints.eu/publikacje/ ocena-stanu-realizacji-planu-modernizacji-technicznej-sz-rp-na-lata-2013-2022-sukces-czy-porazka/ 
Rosomak. Hungary, instead of purchasing new equipment, leased JAS Gripen, but other significant changes did not happen. Only the command structure was changed in both countries. These changes created a NATO-compatible command structure. It is really difficult to rate these changes, because they have barely started functioning yet.

The legal changes caused integration in command structures both in Poland and Hungary. The Hungarian command structure made one step further with the separation of the Commander of Hungarian Defence Forces from the Ministry of Defence physicaIly - moving it to Székesfehérvár from Budapest - and organizationally, as well. Poland and Hungary started to revive their territorial defence systems. This action was different from the other European countries. In Poland, this process started in 2015 and its impacts and goals can be already analysed. The goal for Poland is to reach fifty thousand personnel of territorial armed forces. Hungary has just started this process with aiming to reach the number of twenty thousand reservists.

Analysing the potential of both the Hungarian and Polish Defence Forces we can conclude that an increasing tendency is apparent. Hungary made significant steps to increase the number of personnel in active duty. According to the plans, in $20250.6 \%$ of the Hungarian population will be serving in the defence forces compared to the Polish figure of $0.4 \%$. These numbers prove that in Hungary the arms race will have a bigger impact. However, today these numbers are much lower. It will be more interesting to see if Hungary and other countries in the region will reach $2 \%$ of GDP spent on the military. If the governmental sources are valid, thanks to the $0.3 \%$ GDP growth assigned to military expenditures in 2018, the military equipment purchases will be realised.

The conflicts in the Middle East and in Ukraine had been a real challenge for the military security. According to Barry Buzan, comparing collateral areas, military security could become the greatest danger. That is why military security should never be neglected.

Analysing the objectives of modernization programs in Hungary and Poland, we can declare that the Hungarian Defence Forces are modernizing every component of their military forces. The reason is the lack of any modernization performed earlier. In both countries a lot of agreements have been signed between armament companies and the Defence Ministries, but in practice, not all of them will be implemented. Summarizing, the military potential will be increased drastically in both air and land forces. In the future, more information will be provided about the development of cyber warfare. Nowadays, due to the lack of explicit information, this part of military defence cannot be analysed.

Author: $\quad$ Oliver Balogh. He is a PhD candidate at the Military University of Technology in Warsaw. In 2018 he defended his MA dissertation at the Military University of Technology in Warsaw on the topic of "The Political Position of Military Forces of Hungary and Their Role in the North Atlantic Alliance". He is an author of publications on national security of Hungary, military measures in Central Europe, Hungarian security policy, and crisis management in Hungary. 
How to cite:BALOGH Olivér. The Importance of the Zrínyi 2026 Defence and Military Development Program. Vojenské rozhledy. 2019, 28 (3), 055-070. ISSN 1210-3292 (print), 2336-2995 (on-line). Available at: www.vojenskerozhledy.cz 


\section{Unifying the Armed Forces of Bosnia and Herzegovina - mission completed?}

\section{Unifikace Ozbrojených sil Bosny a Hercegoviny - proces sjednocování}

\section{Věra Stojarová}

Abstract: $\quad$ The Armed Forces of $\mathrm{BiH}$ were officially unified in 2005 and are composed of two founding armies: the Bosniak-Croat Army of the Federation of Bosnia and Herzegovina and the Bosnian Serb Army of Republika Srpska. Even though the unified armed forces celebrated their $13^{\text {th }}$ anniversary in December 2018 and are presented as a success story, the political environment in Bosnia and Herzegovina, particularly in Republika Srpska, does not foster a sense of unity in the armed forces. The paper explores the vulnerabilities that the unified armed forces face, particularly in relation to the process of state building in Bosnia and Herzegovina. The text concludes, that the main concerns for the $\mathrm{BiH}$ armed forces include the old equipment, the economic problems of the country and budget constraints, politicisation and ethnicisation - while ongoing nationalism and the unsure future of $\mathrm{BiH}$ remain the greatest external challenges.

Abstrakt: $\quad$ Ozbrojené síly Bosny a Hercegoviny byly oficiálně sjednoceny v roce 2005 a byly složeny ze dvou zakládajících složek: Armády FBiH a Armády RS. I když sjednocené ozbrojené síly oslavily v prosinci 2018 své třinácté výročí a jsou prezentovány velice pochvalně, politické prostředí v Bosně a Hercegovině, zejména v Republice srbské, nepřispívá k pocitu jednoty ozbrojených sil. Článek se bude zabývat výzvami sjednocených ozbrojených sil ve vztahu k procesu state-buildingu v postkonfliktní Bosně a Hercegovině. K hlavním obavám ozbrojených sil Bosny a Hercegoviny patří staré vybavení, ekonomické problémy země a rozpočtová omezení, politizace a etnicizace; přetrvávající nacionalismus a nejistá budoucnost Bosny a Hercegoviny zůstávají největšími vnějšími problémy.

Keywords: Armed Forces of Bosnia and Herzegovina; Bosnia and Hercegovina; Dayton Peace Agreement.

Klíčová slova: Ozbrojené síly Bosny a Hercegoviny; Bosna a Hercegovina; Daytonská mírová smlouva. 


\section{INTRODUCTION}

The outcome of the war in Bosnia and Herzegovina $(\mathrm{BiH})$ was de facto a divided country and a divided military, and the prospect of unifying the three ethnically-based armies into a single command and control structure seemed utopian. However, the existence of three separate armies was not only a heavy burden for the country's budget, but meant that the units which had fought against each other during the conflict remained separate and would never be able to fight under a unified command. The continuous violence towards returnees, ongoing weapons smuggling and the protests of civilians unhappy with the economic and political transition, helped to strengthen the efforts for demobilisation, cutting the army budgets and final unification. International actors (OHR, OSCE and Nato in particular) helped $\mathrm{BiH}$ to establish the Ministry of Defence in 2004 and the unified Armed Forces of Bosnia and Herzegovina (AFBiH) in 2006. This was probably the greatest achievement in post-Dayton Bosnia and Herzegovina. BiH determined to reduce its military personnel drastically; to unify the armed forces; and to join the Partnership for Peace programme with the final goal of Nato accession. The process of unifying the armed forces was concluded 13 years ago. The question remains of whether the process was successful and whether it is possible to speak of unified armed forces under a unified command; and exclude armed conflict in future.

Existing scholarly accounts of security reform in Bosnia and Herzegovina suggest that a unified military in the country is still an oxymoron. The paper looks closely at the phenomenon of the Armed Forces of Bosnia and Herzegovina and tries to assess the challenges they face. The text also looks at the nexus between the AFBiH and the security of Bosnia and Herzegovina itself and of the region at large. The primary legislation dealing with the defence sector was used as a primary source; several country analyses by different authors were used as secondary sources. Multiple semi-structured interviews with security experts from the Balkan region were undertaken and several surveys undertaken to obtain a better understanding of the issue. My argument is that the Armed Forces of $\mathrm{BiH}$ are far from unified and, unless the country unites, the military cannot be expected to do so. The paper is structured as follows: in the first part the process of unifying the Armed Forces of $\mathrm{BiH}$ is outlined; the second section is devoted to $\mathrm{BiH}^{\prime} \mathrm{s}$ Nato membership aspirations and AFBiH's engagement in the country and abroad; while the third section is devoted to the political, social, economic and other challenges faced by the BiH military.

\section{PROCESS OF UNIFICATION OF THE ARMED FORCES OF BIH}

The Dayton Peace Agreement did not only bring an end to the armed conflict but also resulted in spontaneous demobilisation. Some 370,000 troops under arms (out of an estimated 430,000) left the armed forces in the subsequent five years. The planned demobilisation started three years later. In 1999, the budget for military expenditure was drastically cut by $39 \%$ over the years $1999 / 2000$ and both entities - the Federation of 
$\mathrm{BiH}$ and Republika Srpska (RS) - agreed to reduce military personnel by 15\% in 1999 and by another $15 \%$ the year after. By 2004 , both armies had cut their forces to a combined total of approximately 24,000 active-duty soldiers, supported by some 15,000 reservists and as shown in the graph, in 2016 , the army was down to the current 10,5000 soldiers.

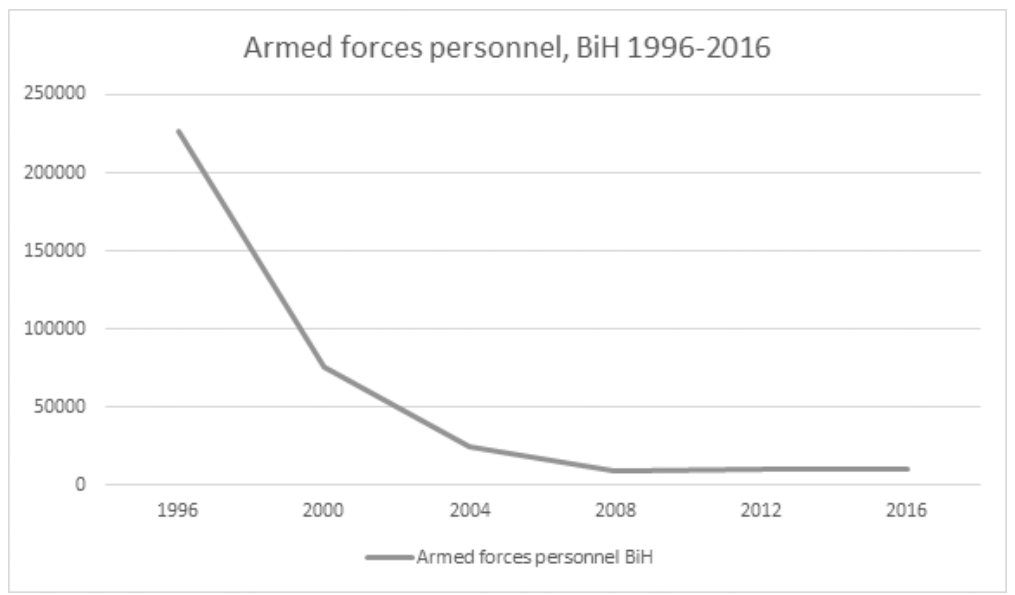

Figure 1: Armed forces personnel, BiH 1996-2016

The Dayton Peace Agreement left the country more divided than it was before the war. It was not just the country that was divided; there were de facto three separate armies in Bosnia and Herzegovina - Bosnian Croat, Muslim (Bosniak) and Bosnian Serb - which were integrated neither structurally nor operationally, with no cooperation between them whatsoever. The international community strove for unification at the level of the single state, but the memories of war were still fresh and the judicial proceedings related to war crimes perpetrated by one of the armies were still ongoing. It was as late as 2004 when the International Court for the former Yugoslavia ruled that the massacre of the male inhabitants of the Srebrenica enclave by the Army of Republika Srpska (Vojska Republike Srpske, VRS) constituted a crime of genocide under international law; the ruling was then upheld by the International Court of Justice in 2007. In spring 2019, Bosnian Serb general Ratko Mladić was sentenced to life in prison for crimes against humanity committed during the Bosnian conflict, inter alia in Srebrenica. Milorad Dodik, Serbian member of the tripartite $\mathrm{BiH}$ presidency and prominent long-term politician in RS, has repeatedly downplayed the Srebrenica massacre, most recently in spring 2019 calling it a "fabricated myth"; other Bosnian Serb politicians also denied the genocide, including Mladen Grujičić, the current mayor of Srebrenica. Republika Srpska set up a commission to establish the "truth" of what occurred; the memories of war were still fresh and present. RS politicians repeatedly claimed there was no will to have joint or unified armed forces and the effort of the international community to establish a single military body in Bosnia and Herzegovina seemed utopian. Some even claimed that the time had come to recognise the reality of a divided country and a divided military. 

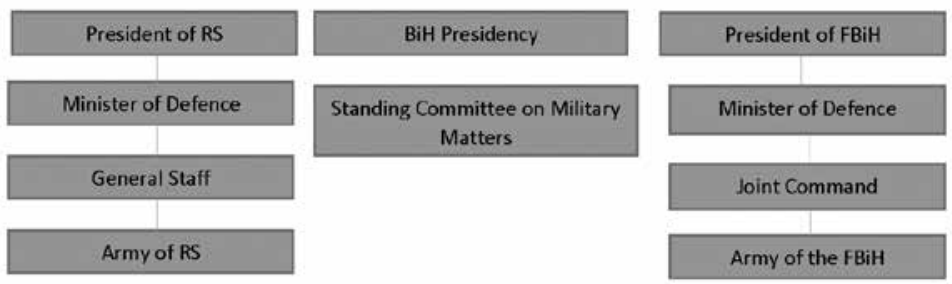

Figure 2: The post-Dayton Command Structure in $\mathrm{BiH}$

International pressure helped the process of unification. In 2003, a Commission for Defence Reform was established, and the first law necessary for a single ministry of defence for $\mathrm{BiH}$ was adopted. State-level parliamentary oversight was created through the establishment of a Defence and Security Committee in the BiH Parliamentary Assembly; on the basis of the Commission's work, ${ }^{1}$ the White Paper on BiH Defence was released in 2005, and further defence legislation was adopted. ${ }^{2}$ In 2004, the first-ever joint collective exercise was conducted between the Army of RS and the Army of FBiH and the whole process of unification was completed around 2006. Thus, the three armies that had fought each other were turned into a single multi-ethnic military force, serving the state of $\mathrm{BiH}$ rather than any particular entity or any of BiH's three constituent peoples. $\mathrm{BiH}$ abolished conscription in 2006 and, in the same year, the presidency defined the size, structure and locations of the newly created $\mathrm{AFBiH} .^{3}$

\begin{tabular}{|l|l|l|l|l|l|}
\hline & Bosnian Serb & Muslim & Bosnian Croat & Other & Total \\
\hline $\mathbf{1 9 9 2 / 9 3}$ & 67,000 & 50,000 & 50,000 & & 167,000 \\
\hline $\mathbf{1 9 9 5 / 9 6}$ & 75,000 & 92,000 & 50,000 & & 217,000 \\
\hline $\mathbf{2 0 0 0 / 0 1}$ & 30,000 & 30,000 & 10,000 & & 70,000 \\
\hline $\mathbf{2 0 1 3}$ & $3,533(33.6 \%)$ & $4,826(45.9 \%)$ & $2,084(19.8 \%)$ & $74(0.7 \%)$ & 10,450 \\
\hline $\mathbf{2 0 1 6}$ & $3,528(33.6 \%)$ & $4,820(45.9 \%)$ & $2,079(19.8 \%)$ & $73(0.7 \%)$ & 10,500 \\
\hline
\end{tabular}

Figure 3: Military Forces in Bosnia and Hercegovina 1992-2013

1 KOMISIJA ZA REFORMU ODBRANE. OSBiH: Jedna vojna sila za 21. vijek. Izvještaj 2005. Sarajevo. http:// www.mod.gov.ba/files/file/dokumenti/Izvjestaj-2005-bs.pdf.

2 MINISTARSTVO ODBRANE. Bijela knjiga odbrane Bosne i Hercegovine. Sarajevo, Juni 2005, http://www. mod.gov.ba/files/file/dokumenti/Bijela-knjiga-bs.pdf; MINISTARSTVO ODBRANE. Vojna doktrina. Sarajevo undated http://www.mod.gov.ba/files/file/dokumenti/vojnadoktrina/vojnadoktrina. pdf. All documents related to defence in $\mathrm{BiH}$ are available at http://www.mod.gov.ba/dokumenti/ odbrambeni_dokumenti/?id=21743.

3 MAXWELL, R., OLSEN, J.A. Destination NATO. Defence Reform in Bosnia and Herzegovina 2003-13. Royal United Service Institute for Defence and Security Studies 2013. https://jfcnaples.nato.int/hqsarajevo/ page14313506/destination-nato-english. 
The AFBiH is not a large military force and according to the latest figures (2018), it has just over 10,000 active-duty soldiers, 1,000 civilians and 5,000 reservists. The composition of the armed forces is based on quotas which are linked to the 1991 census. The current military body consists of more than 3,000 Serbs, almost 5,000 Muslims and over 2,000 Croats. The statistics from 2014 show that women make up $6.6 \%$ of the AFBiH personnel. Women serving in the ranks of the AFBiH are mostly graduates of civilian schools, and obtained further military education through various individual and institutional education programmes.

The armed forces consist of army, air force and air defence units. The branches of the AFBiH are: Infantry, Artillery, Air Defence, Armoured Mechanised Units, Aviation, Engineering, Communications, NBC protection, Electronic Surveillance and Defence, Air Surveillance and Rapid Response and Military Intelligence. Compared with other armed forces in the region, the AFBiH is small, and similar in size to the armed forces of Slovenia (approx. 7,300 personnel).

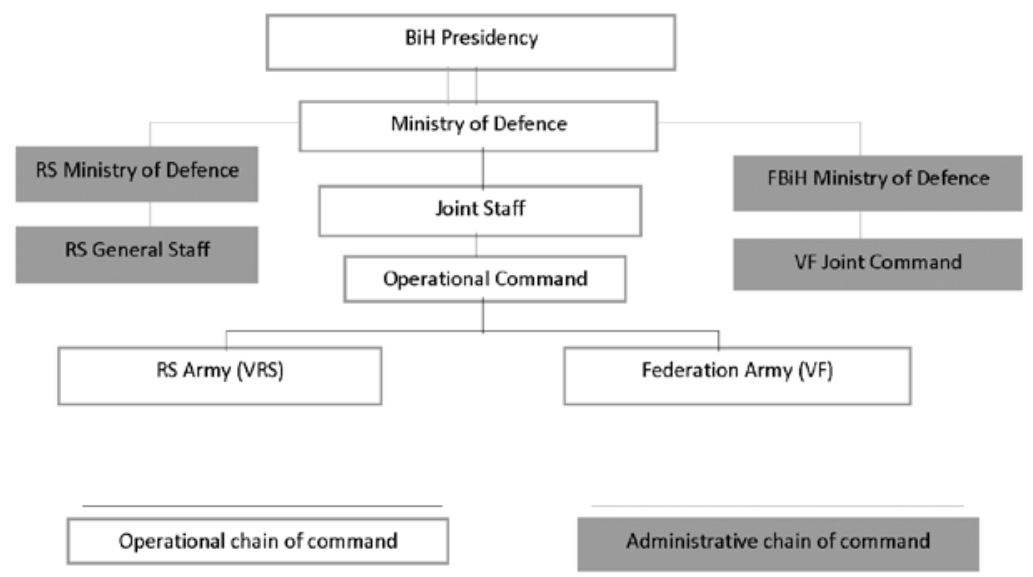

Figure 4: Command and Control of the Armed Forces of $\mathrm{BiH}^{4}$

The military structure is divided into operational and administrative commands, while all of the command structures are multi-ethnic. The mono-ethnic infantry battalions are incorporated into brigades that include battalions from all three constituent nations with the requirement that each ethnicity makes up at least $10 \%$ of the units. ${ }^{5}$ The mission of $\mathrm{AFBiH}$ is defined as: ensuring the sovereignty, territorial integrity, political independence and international legal status of $\mathrm{BiH}$, promoting the $\mathrm{BiH}$ foreign policy goals, meeting the international commitments of $\mathrm{BiH}$, and protecting $\mathrm{BiH}$ nationals. The tasks of the AF$\mathrm{BiH}$ are listed as: participating in collective security operations, peace and self-defence

4 MINISTARSTVO ODBRANE BIH. Bjela knjigao dbrane Bosne i Hercegovine. Sarajevo 2005. http://www.mod.gov.ba/files/file/dokumenti/Bijela-knjiga-bs.pdf.

5 BASSUENER, K. The Armed Forces of Bosnia and Herzegovina: Unfulfilled promise. Berlin /Sarajevo 2015. 
support operations, including the fight against terrorism, providing military defence to $\mathrm{BiH}$ and its citizens in case of attack, assisting the civilian authorities in response to natural and other disasters and catastrophes, clearing landmines in $\mathrm{BiH}$, and meeting $\mathrm{Bi}$ $\mathrm{H}^{\prime}$ s international commitments ${ }^{6}$

\section{NATO MEMBERSHIP ASPIRATIONS AND AFBIH ENGAGEMENT IN BIH AND ABROAD}

Nato played a key role in stabilising Bosnia and Herzegovina in the post-conflict era, through the deployment of peace-keeping forces over a nine-year period from 19952004 until primary responsibility was handed over to the European Union (EU). In 2003, the Presidency of $\mathrm{BiH}$ expressed readiness to engage in the process of Euro-Atlantic integration and actively contribute to collective security. The message consisted of a commitment to include $\mathrm{BiH}$ in European and Euro-Atlantic integration and in the Partnership for Peace programme, and to implement the required defence system reforms and reorganisation of the armed forces. ${ }^{7}$ Nato membership was identified as one of the priorities of foreign policy, as indicated in the Bosnia and Herzegovina Defence White Paper.

In 2006, BiH joined the Partnership for Peace (PfP) programme. An Individual Partnership Action Plan (IPAP) was agreed with Nato in 2008; its goal was to bring together all the cooperation mechanisms through which the country interacts with the Alliance, sharpening the focus of activities to better support domestic reform efforts. Two years later, $\mathrm{BiH}$ was invited to join the Membership Action Plan; in 2018, Alliance foreign ministers decided that Nato was ready to accept the submission of the country's first Annual National Programme. ${ }^{8}$ Nato keeps a military headquarters in Sarajevo to assist the Bosnian authorities with reforms related to the PfP and Nato integration; its secondary goal is to provide logistics and other support to the $\mathrm{EU}$. $\mathrm{BiH}$ has also established a diplomatic mission at Nato Headquarters as well as a liaison office at the Supreme Headquarters Allied Powers Europe (Shape).

From a historical perspective, the relationship between $\mathrm{BiH}$ and Nato is unique. Integration with Nato and membership of PfP was not viewed positively by all three ethnic groups, particularly the Serbs, and certainly not as a historical milestone, which is how it has been presented. Nevertheless, without the prospect of Nato membership or international pressure behind the effort, the country would by no means be willing and able to unify its armed forces and to create an integrated defence system for the whole of Bosnia and Herzegovina.

6 MINISTARSTVO ODBRANE I ORUŽANE SNAGE BOSNE I HERCEGOVINE. Brošura. Sarajevo 2015, http:// www.mod.gov.ba/foto2015/1809-Bosanski\%20jezik-.pdf.

7 DEFENCE REFORM COMISSION. Put u partnerství za mir: Izveštaj komisije za reformu u oblasti odbrane. Sarajevo 2003. http://www.mod.gov.ba/files/file/dokumenti/Partnerstvo-za-mir-bs.pdf.

8 NATO. Relations with Bosnia and Herzegovina. 2008. https://www.nato.int/cps/en/natohq/ topics_49127.htm. 
Despite all of these impediments, the AFBiH has performed admirably both at home and abroad in peace-keeping operations. Even prior to unification, the AFBiH was deployed in Iraq as an all-volunteer force in early 2006. Since $2009, \mathrm{BiH}$ has contributed to the Nato-led International Security Assistance Force (ISAF) in Afghanistan as part of the German and Danish contingents and, following the disbanding of ISAF at the end of 2014, its military has been part of Nato's Resolute Support Mission (RSM) to provide further training, advice and assistance for the Afghan security forces (63 troops out of a total of 17,034 provided by 39 contributing nations). ${ }^{9}$ The AFBiH also performed well during the 2014 flood emergency, saving the lives and property of BiH citizens. Their effort was praised and their reputation enhanced after the floods. The AFBiH worked closely with EUFOR which provided them with helicopters to evacuate people, was involved in delivering humanitarian aid and in clean-up activities. However, the natural disaster also showed the military's deficiencies in equipment, training and preparation for situations of this kind. ${ }^{10}$ Another challenge that AFBiH has been facing is demining, since landmines are still killing people in $\mathrm{BiH}$.

\section{Challenges fOR the AFBiH}

\subsection{Internal challenges}

One of the first issues the armed forces had to face was property and equipment. The only defe3nce premises controlled directly by the state of $\mathrm{BiH}$ were the offices occupied by the MoD, Joint Staff and Operational Command, and the only equipment consisted of the weapons, ammunition and vehicles deployed in Iraq. Everything else was controlled by the entities (Federation of $\mathrm{BiH}$ and Republika Srpska) and was of a scale suitable for much larger forces than AFBiH. Finally it was agreed that the real estate (required for defence purposes) would be transferred from the entities to the state. The arms, weapons and equipment (AWE) became the subject of heated discussions, as the international community did not want them to fall into the wrong hands.

In 2008, it was finally agreed that $\mathrm{BiH}$ should comply with its obligations under international law to minimise the proliferation of $A W E$, and that weapons and equipment would become state property, pending disposal of surplus items. Further discussion focused on the disposal of surplus AWE (an estimated 18,000 tons) - Bosnian policy-makers wanted

9 NATO. RSM. Key facts and figures. 2019. https://www.nato.int/nato_static_fl2014/assets/pdf/ pdf_2019_03/20190305_2019-03-RSM-Placemat.pdf.

10 EUROPEAN COMMISION. Floods in Bosnia and Herzegovina. 2014. http://ec.europa.eu/echo/files/ news/bosnia herzegovina_floods_joint_report_en.pdf; HUSEINBASIC, S. Floods in Bosnia and Herzegovina. Lessons to learn. 2014. https://www.coe.int/t/dg4/majorhazards/activites/2014/ SamirHuseinbqsic_BiH_Floods.pdf. 
this disposal to occur through sales, while the international community pressed consistently for the dismantling or destruction of surplus items. The final agreement was that the state should retain $20 \%$ of any profits from sale while the remaining $80 \%$ would go to the entity originally owning the AWE. This of course proved to be controversial and hard to implement given the mutual suspicions of both entities regarding the transparency of the disposal process and associated profits. Moreover, another problem, which will only emerge in time, is the age of the AWE which raises safety and security concerns, including the risk of leakage from storage sites due to the poor storage conditions. ${ }^{11}$ The registration of immovable defence property was also a reason why Nato held up the accession process until 2018. Even though Nato decided to move forward, deciding not to allow Republika Srpska to block the whole process, the property must still be registered at the federal level for the Membership Action Plan to conclude.

Experts have emphasised that budget constraints have had an effect on the quality of equipment and training: „Only one-third of the engineering equipment is operational by peacetime standards, in a war situation it's a lot more. "12 Azra Mulahasanović, the OSCE senior public information officer, stated that "more than $90 \%$ of the allocated budget is spent on personnel costs (i.e., salaries), only a relatively small portion on maintenance, and almost nothing on procurement." ${ }^{13}$ Selmo Cikotić, former minister of defence, also highlighted the lack of money: ' $\mathrm{BiH}$ 's defence budget, which is around $1 \%$ of GDP, is not enough - it would have to be doubled to reach Nato standards in this regard."14

Some challenges for AFBiH also lie in the system as such and in structural changes. Marina Pendeš, who was appointed minister of defence in 2015, was charged with negligent performance of official duties and with forging documents in 2016. A year later, she was acquitted by the court of all charges and remained in post. Many experts agree that the continuing politicisation of the army is related not only to the positions in the MoD but also to key positions in the structure. Another problem is the constitutional setting, as the important posts are all appointed on an ethnic, rather than professional, basis and according to links to political parties. The practice of sending Serbs for supplementary training in Serbia, Croats to Croatia and Bosniaks to Turkey also reveals the persistent polarisation in the army ranks. Some of the experts also described ostentatious displays of religiosity for personal advancement. The evidence of religious/party patronage in the army emerged when it was leaked that the MoD was funding Hajj pilgrimages to Mecca and Orthodox devotional trips to Greece for some AFBiH members. ${ }^{15}$ All of my interviewees stated that ethnic polarisation prevails and that "according to the information available to the general public, the army uses nationalistic flags, symbols, heraldic signs and also

11 MAXWELL, R., OLSEN, J.A. Destination NATO. Defence Reform in Bosnia and Herzegovina 2003-13. Royal United Service Institute for Defence and Security Studies 2013. https://jfcnaples.nato.int/hqsarajevo/ page14313506/destination-nato-english.

12 BASSUENER, K. The Armed Forces of Bosnia and Herzegovina: Unfulfilled promise. Berlin /Sarajevo 2015.

13 MULAHASANOVIĆ, Azra. Senior Public Officer at OSCE. Questionnaire via email, 26 March 2019, Sarajevo.

14 CIKOTIĆ, Selmo. Former Minister of Defence. Questionnaire via email, 18 April 2019, Sarajevo.

15 BASSUENER, K. The Armed Forces of Bosnia and Herzegovina: Unfulfilled promise. Berlin /Sarajevo 2015. 
the anthems of other states. "16 Most of the interviewees agreed that they could not imagine the $\mathrm{AFBiH}$ instigating destabilisation in $\mathrm{BiH}$, though there was unanimous agreement that - should something trigger an armed conflict in $\mathrm{BiH}$ - „,in this situation three national armies would again emerge as $\mathrm{BiH}$ is a much more divided society than in $1992 " .{ }^{17}$

\subsection{External drivers - economy, politics and society}

Even though the representatives of $\mathrm{BiH}$ stress the progress made and the will for a peaceful future, ${ }^{18} 24$ years after signing the Dayton Peace Agreement, the country has not recovered from the impact of the war and is still facing the challenges of economic transition from a state economy to a free-market one. The budget constraints and the demobilisation of the army coincided with high unemployment and difficult re-integration of ex-combatants into civilian life. Their military background proved to be a disadvantage when seeking civilian jobs. The high unemployment rate has also been fed by the return of refugees and the minimal opportunities for returnees in the labour market. The grey market, unofficial economy and organised crime flourished while pension payments were delayed - this was made worse by the poor state of the economy overall. Last but not least, the country contributed to the export of mercenaries to other parts of the world (Bosniaks joined Chechen fighters in 2000 and assisted the Kosovo Liberation Army in 1999; Bosnian Serbs assisted Yugoslav security forces in Kosovo in 1998 and were also part of the White Legion in Zaire fighting on the side of President Mobutu Sésé Seko during the First Congo War in 1996). ${ }^{19}$

The political climate in Bosnia and Herzegovina has worsened since the Dayton Peace Agreement. The Peace Accords stopped the war which caused a great many casualties, but they also created a dysfunctional state, in which part of the population does not want to live and where mutual trust has not been established. The government of Republika Srpska has for years ruled out joining Nato and emphasised the 2017 Resolution on its military neutrality, pointing to the Nato air campaigns against RS and Serbia respectively during the 1990s. Dodik has been calling for the demilitarisation and neutrality of the country while misusing the AFBiH for political purposes. In early 2017, the US Department of the Treasury's Office of Foreign Assets Control introduced sanctions against Dodik, saying he posed a "significant threat to the sovereignty and territorial integrity of Bosnia and Herzegovina." ${ }^{20}$ The sanctions block Dodik's access to assets and

16 JOVICIĆ, Dragomir. Interview, October 2018, Sarajevo.

17 JOVICIĆ, Dragomir. Questionnaire via email. 20 March 2019.

18 Interview with Selmo Cikotić, former defence minister of $\mathrm{BiH}, 2013$. Available at https://www.youtube. com/watch?v=akmi6KDqpVs.

19 KING, J., DORN, W., HODES, M. An unprecedented experiment: Security sector reform in Bosnia and Herzegovina, Bonn 2002.

20 US EMBASSY IN BOSNIA AND HERZEGOVINA. U.S. Ambassador Cormack's statement on U.S. sanctions against Milorad Dodik. At https://ba.usembassy.gov/information-u-s-sanctions-milorad-dodik/. 
any interests in property in the US or within US jurisdiction and US citizens are banned from engaging in transactions with him. Despite strong lobbying, the sanctions have remained in place. The direct reason for their imposition was the January 9 celebration of a public holiday in Republika Srpska.

The controversy arises every year when a military and civilian parade is held in Banja Luka to mark the Day of Republika Srpska despite the fact that BiH's Constitutional Court ruled in 2015 that marking this holiday excluded non-Serbian citizens and was therefore unconstitutional. The date marks the establishment of Republika Srpska in 1992, as well as celebrating the patron saint of RS, St. Stephen. The Republika Srpska authorities contested the decision of the $\mathrm{BiH}$ Constitutional Court and called for a referendum in 2016 in which a majority of RS citizens supported the celebrations. General Sefer Halilović of the AFBiH threatened that a conflict would flare up if the referendum was held, and his comments were glossed by Minister of Foreign Affairs Ivica Dačić of Serbia as the greatest threat to peace and stability in the region. Bosniak member of the Bosnian Presidency Bakir Izetbegović stated that the referendum was an example of breaching the Dayton Agreement. ${ }^{21}$ Nevertheless, every year, the parade of firefighters, cultural and sports groups takes place to celebrate the Day of Republika Srpska and is accompanied by an army parade. This is deplored both by the international community and the representatives of $\mathrm{BiH}$. Obviously, the presence of a ceremonial unit from the Sixth Infantry Brigade of $\mathrm{AFBiH}$ is not authorised by the $\mathrm{BiH}$ Ministry of Defence but is ordered by the chairman of the Presidency of BiH Mladen Ivanić. The MoD has ordered an investigation into responsibility for this act. ${ }^{22}$ As a former minister of defence, Selmo Cikotić, stated in an interview: "The influence and control of politics or politicians is the biggest and most serious challenge for the functioning and progress of the $\mathrm{AFBiH}$, in both positive and negative terms." 23 The nationalistic politics remains one of the main threats for the AF$\mathrm{BiH}$ and so for the security in $\mathrm{BiH}$ as such. The current negotiations between Kosovo and Serbia about the border adjustments present a threat for sovereignty of the country and could result in strong accent on separatist tendencies in RS, which might be supported by Serbia and Russia.

CONCLUSION - THE UNIFIED ARMED FORCES: MISSION COMPLETED?

My analysis shows that the process of unifying the AFBiH has been one of the more successful of BiH's achievements, though the armed forces still face many challenges

21 Šef ratnog štaba: Ako bude referenduma, neće biti $R S .20 .99 .2016 . \quad$ B92. https://www.b92.net/info/vesti/index.php?yyyy=2016 \& mm=09\&dd=20\&nav_ category=167\&nav_id=1178741.

22 Ministarstvo odbrane BiH: Nismo dali odobrenje za ućešce OSBiH u obilježavanju Dana RSa. Klix-ba. 9. 1. 2017. https://www.klix.ba/vijesti/bih/ministarstvo-odbrane-bih -nismo-dali-odobrenje-za-ucesce-osbih-u-obiljezavanju-dana-rs-a/170109077.

23 CIKOTIĆ, Selmo. Former minister of defence. Questionnaire via email, 18 April 2019, Sarajevo. 
and constraints. The armed forces were downscaled from 167,000 soldiers to 10,000 . The unification effort, from three different armies with three different commands to one unified body under one common minister of defence, not following either the original entities or ethnic lines, is also commendable.

Despite Nato involvement in the Bosnian and Kosovan war against Serbian positions, $\mathrm{BiH}$ identified Nato membership as a priority of its foreign policy as stated in the Bosnia and Herzegovina Defence White Paper, irrespective of the fact that Republika Srpska opposes that aim. Bosnia and Herzegovina also joined the Partnership for Peace (PfP) programme in 2006, while the Individual Partnership Action Plan (IPAP) was agreed with Nato two years later. In 2018, the Alliance decided that $\mathrm{BiH}$ was ready to submit its first Annual National Programme, with the ultimate goal of Nato accession. Further successes of the AFBiH have included participation in the Nato-led International Security Assistance Force (ISAF) in Afghanistan and, following the termination of ISAF at the end of 2014, in Nato's Resolute Support Mission (RSM). The military was praised both nationally and internationally for its actions during the floods in Bosnia in 2014.

The main concerns for the $\mathrm{BiH}$ armed forces include the old equipment which raises security issues, the economic problems of the country and budget constraints, politicisation and ethnicisation - while ongoing nationalism and the unsure future of $\mathrm{BiH}$ remain the greatest external challenges. Only one of my interviewees stated that the armed forces could trigger a conflict, while all of the others believed that it was highly unlikely. Nevertheless, they unanimously stated that, in the event of armed conflict, the army would split along ethnic lines and would take part in the conflict. Not surprisingly, nationalistic politics remains one of the main threats for the $\mathrm{AFBiH}$ and so for security in $\mathrm{BiH}$ and indeed in the whole region. The developments in Republika Srpska and the negotiations between Kosovo and Serbia about border adjustments might result in separatism in RS, which might be supported by Serbia and Russia. Nevertheless, to conclude, the process of unifying AFBiH has been largely successful, unlike the post-conflict building reconstruction in Bosnia and Herzegovina at large. Nevertheless, in order to call it a success, both processes have to be completed concurrently. There can be no successful story to tell about the unification of the Bosnian military without successful post-conflict state building in $\mathrm{BiH}$.

This paper was written as part of the research project SIVARBAL (Proposal for a system of indicators of early warning of possible crisis situations in the Balkans), funded by the Ministry of Defence of the Czech Republic (defence research programme).

Author: Věra Stojarová, PhD., graduated at Palacky University (2002) and Masaryk University (2006). Currently, she works as a researcher at the Department of Political Science of the Faculty of Social Studies at Masaryk University focusing on the security of the Western Balkans. She is the author of several monographs and expert articles focusing on extremism and radicalism in the area of the Western Balkans. 
How to cite: STOJAROVÁ Věra. Unifying the Armed Forces of Bosnia and Herzegovina - mission completed? Vojenské rozhledy. 2019, 28 (3), 071-082. ISSN 1210-3292 (print), 2336-2995 (on-line). Available at: www.vojenskerozhledy.cz 


\title{
Information and Psychological Operations as a Challenge to Security and Defence
}

\section{Informační a psychologické operace jako výzva pro bezpečnost a obranu}

\author{
Petra Vejvodová
}

Abstract: The article focuses on information and psychological operations as a challenge for the security and defence establishments of NATO member states. A conceptualisation of the terms 'information operations' and 'psychological operations' is discussed in the contexts of reshaping the war-and-peace dichotomy, and of resilience and deterrence. It is suggested that these terms suffer from a normative approach to the paradigm of war and peace, and to the use of non-military means. This may lead to the greater vulnerability of security and defence systems in confrontation with an adversary. Also, special attention is paid to the vulnerabilities of security and armed forces, being overlooked in concepts of resilience.

Abstrakt: CClánek se věnuje informačním a psychologickým operacím jako výzvě pro bezpečnostní a obranné systémy zemí NATO. Nejprve jsou jednotlivé termíny diskutovány v souvislosti s pojímáním dichotomie válka a mír, a také v kontextu odolnosti a odstrašování. Text upozorňuje na to, že definice pojmů jsou ovlivněny normativním př́stupem vůči paradigmatům války a míru a užití nevojenských prostředků. Tato situace vede k vyšší zranitelnosti bezpečnostních a obranných systémů při jejich konfrontaci s protivníkem. Zvláštní pozornost je také věnována zranitelnostem bezpečnostních a ozbrojených složek, které jsou v rámci formulací strategií na zvýšení odolnosti přehlíženy.

Key words: Information Environment; Information Operations; Psychological Operations; Resilience; Security Forces; Vulnerability.

Klíčová slova: Informační prostředí; informační operace; psychologické operace; odolnost; bezpečnostní složky; zranitelnost. 


\section{INTRODUCTION}

Information operations, psychological operations: two terms very often articulated in the context of hybrid warfare, irregular warfare, information warfare etc. Western democracies and NATO try to define carefully what these terms mean to promote as much transparency as possible. Nevertheless, we suggest that current definitions do not reflect the reality, probably because the Western approach differs from that of the West's adversaries, the ones who actively develop and deploy such operations in the modern age. Therefore, this article discusses and highlights the main issues and weaknesses related to the Western understanding of information and psychological operations, and also reflects on the gap in civil-military affairs. We witness intense discussions about the protection of society against the influence of information and psychological operations, but these reflect only civil society. Military and security representation is missing from this discussion. ${ }^{1}$

\section{DIFFICULTIES IN UNDERSTANDING INFORMATION AND PSYCHOLOGICAL OPERATIONS}

According to NATO and the US Department of Defense, information operations are defined as 'the integrated employment, during military operations, of information-related capabilities in concert with other lines of operation to influence, disrupt, corrupt, or usurp the decision-making of adversaries and potential adversaries while protecting our own.' ${ }^{2}$ Information operations are coordinated military activities in an information environment having specifically defined goals. They represent offensive and defensive measures focused on influencing an adversary's decisions, manipulating information and information systems. They also include measures protecting a country's own decision-making processes, information and information systems.

Information operations may affect all three dimensions of the information environment. In the psychological dimension they have potential to influence command and control systems, key decision makers and supporting infrastructure. The physical dimension covers human beings, but also command and control facilities and ICT. What is important is that the physical dimension is not connected only to military or nation-based systems and processes. In the psychological dimension, information operations target the ways information is collected, processed, stored, disseminated and protected.

1 This paper was written under the project Optimisation of Intelligence Activities and Intelligence Institutions in the Changing Environment (OPTIZ9070204510), funded by the Ministry of Defence of the Czech Republic as part of the 'Development of the Armed Forces of the Czech Republic! (907 020) defence research programme.

2 Joint Chief of Staff. Joint Publication 3-13. Information operations. [online] 2014 [cit. 2019-04-30]. Available at: https://www.jcs.mil/Portals/36/Documents/Doctrine/pubs/jp3_13.pdf. 
Operations in these dimensions affect the content and flow of information. Last but not least, in the cognitive dimension, information operations influence the minds of those who transmit, receive, respond to or act on information. The cognitive dimension means individuals and groups, their individual and cultural beliefs, norms, vulnerabilities, motivations, emotions, experiences, education, mental health, identities and ideologies ${ }^{3}$. Understanding these factors is crucial for developing best operations in order to influence decision makers and produce the desired effect.

Information operations are not only a collection of single information activities. They are a process of integrating the effects of single information activities, together leading to influencing an adversary. Information operations integrate psychological operations (psyops), operations security, information security, deception, electronic warfare, kinetic actions, key leader engagement and computer network operations. All together they target the will of adversaries to fight, their understanding of the situation, and their capabilities.

Information activities aimed at influencing the adversary mainly focus on decision-makers who have the ability to influence the situation. Activities in this case include questioning the legitimacy of political leaders, undermining the morals of the population or the military, polarising society and so on. Information activities to affect the understanding of the situation seek to influence the information available to the enemy for their decision-making processes. They include disseminating disinformation, using military-scale mock-ups to fool the enemy's radar systems, deliberately leaking distorted information, destroying or manipulating information in the opponent's information systems, and so on. The third kind of information activities is to act on the enemy's abilities and try to disrupt his ability to understand information and promote his will. These include disruptions to internet connections, the physical destruction of infrastructure, cyber attacks and so on.

Information operations are sometimes mistakenly referred to as strategic communication. Although these two terms may seem very similar, there are differences between them. Strategic communication is driven from a political, strategic level; its reach and audience are global and it operates only in the cognitive dimension of the information environment. By contrast, information operations are managed from an operational, military level, have a well-defined scope of action and audience, and operate in all three dimensions of the information environment. ${ }^{4}$ Strategic communication is thus a broader term to which information operations are subordinate.

In this approach, information operations concentrate information-technical and information-psychological activities during military operations. In this article, we are interested in information-psychological activities, which are often understood as psyops. As was mentioned, psychological operations are defined as one type of activity belonging

3 Joint Chief of Staff. Joint Publication 3-13. Information operations. [online] 2014 [cit. 2019-04-30]. Available at: https://www.jcs.mil/Portals/36/Documents/Doctrine/pubs/jp3_13.pdf.

4 DIVIŠOVÁ, Vendula. Strategická komunikace v protipovstaleckých operacích NATO. Obrana a strategie [online]. 24(2), 105-118 [cit. 2019-04-30]. ISSN 12146463. Available at: https://www.obranaastrategie. cz/cs/archiv/rocnik-2014/2-2014/clanky/strategicka-komunikace-v-protipovstaleckychoperacich-nato.html.; ŘEHKA, Karel. Informační válka. Praha: Academia, 2017. ISBN 978-80-200-2770-2. 
to information operations. Allied Joint Doctrine AJP 3-10.1 for psychological operations from 2014 defines psyops as 'planned activities using methods of communication and other means directed at approved audiences in order to influence perceptions, attitudes and behaviour, affecting the achievements of political and military objectives. ${ }^{\prime 5}$ It is also understood that all actions in the area of operations undertaken by NATO are highly probable to have a psychological impact.

Psychological operations are pre-planned activities using communication methods and other resources aimed at selected target audiences to influence their moods, attitudes, behaviour, perception and interpretation of reality. Thus, by using special methods, it is possible to induce desirable responses in the target population, which in the broader context contributes to the fulfilment of specific political and/or military objectives. Every psychological operation is based on a certain psychological theme (the main, carefully prepared narrative, or ideas). The greater the target audience receptivity, i.e. sensitivity to specific psyops tools, the greater the probability of success of the whole psychological operation ${ }^{6}$.

The importance of psyops is based on the belief that the psychological nature of the conflict is as important as the physical. People's attitudes and behaviour affect the course and outcome of the conflict and the nature of the environment in which the conflict takes place. For a well-conducted psychological operation, it is important to know the target audience, its will and motivation. The psyops work with these elements and aim to influence them, weakening the adversary's will, strengthening the target group's commitment, and gaining the support and cooperation of undecided groups.

The poorly defined relationship between information operations and psychological operations is a problem for the definition of psyops themselves. From the logic of provided definitions, psyops help to fulfil the aims of information operations at the information-psychological level of military operations. Aiming at the cognitive dimension of the information environment, psyops influence the perceptions, attitudes and behaviour of the target audience, which should lead to an effect on decision makers. So they are a sub-category of information operations, coordinated through information operations processes. Allied Joint Doctrine AJP 3-10.1 states that psyops are conducted across the

5 NATO Standardization Office. Allied Joint Doctrine for Psychological Operations AJP 3-10.1. [online] Brussels: North Atlantic Treaty Organization, NATO Standardization Office, 2014 [cit. 2019-04-30]. Available at: https://assets.publishing.service.gov.uk/government/uploads/system/uploads/ attachment_data/file/450521/20150223-AJP_3_10_1_PSYOPS_with_UK_Green_pages.pdf. obrannou standardizaci, katalogizaci a státní ověřování jakosti, Odbor obranné standardizace, 2016 [cit. 2019-04-30]. Available at: http://oos.army.cz/terminologicky-slovnik-aap-6; NATO Standardization Office. NATO Glossary of Terms and Definitions. AAP-06. [online] Brussels: North Atlantic Treaty Organization, NATO Standardization Office, 2018 [cit. 2019-04-30]. Available at: http://oos.army.cz/terminologickyslovnik-aap-6; NATO Standardization Office. Allied Joint Doctrine for Psychological Operations. Allied Joint Publication - 3.10.1. Brussels: North Atlantic Treaty Organization, NATO Standardization Office, 2014. 
full spectrum of military operations ${ }^{7}$. Here, a first contradiction arises, when we compare the NATO understanding of psyops with the understanding of the Czech army, which sees psyops as „planned and purposeful psychological influence on target groups, carried out in peacetime under a state of external threat to the country, and in wartime "8. Based on this, psyops can be conducted both in times of peace and war. In this understanding, psyops erase the dichotomy between peace and war and imply a shift in the understanding of the tasks of the armed forces to the effect that even during peacetime the security and defence establishments needs to be active and conduct operations. But as a sub-category of information operations, psyops should be connected only with military operations - normally undertaken during war. Support for a redefinition of terms comes from e.g. Brangetto and Veenendaal from NATO Cooperative Cyber Defence in their paper, in which they introduce psychological operations as an activity also undertaken during peacetime. They talk about a category of operations they describe as "strategic communication and propaganda9"' (see Figure 1).

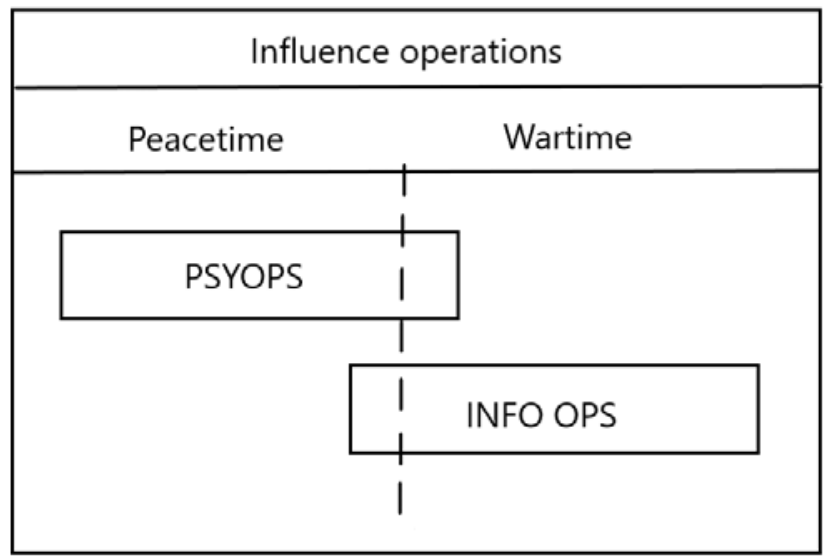

Figure 1: Psyops vs Info ops (modified according to Brangetto and Veenendal)

The intention is clear here, but it causes another terminological confusion when mixing strategic communication and psychological operations that comes from that fact that in NATO terminology psyops are replaced by strategic communication (stratcom). It

7 NATO Standardization Office. Allied Joint Doctrine for Psychological Operations AJP 3-10.1. [online] Brussels: North Atlantic Treaty Organization, NATO Standardization Office, 2014 [cit. 2019-04-30]. Available at: https://assets.publishing.service.gov.uk/government/uploads/system/uploads/ attachment_data/file/450521/20150223-AJP_3_10_1_PSYOPS_with_UK_Green_pages.pdf.

8 103rd Centre of Civil-military cooperation and psychological operations of the Czech Army. [online] Official website [cit. 2019-04-30]. Available at: http://www.103cp.army.cz/.

9 BRANGETTO, Pascal, VEENDENDAAL, Matthijs, A. Influence Cyber Operations: the Use of Cyberattacks in Support of Influence Operations. 8th International Conference on Cyber Conflict. Tallinn: NATO CCD COE Publications, 2016. 
may be better to say that the definitions of both are the same in principle. On one hand, Allied Joint Doctrine AJP 3-10.1 defines psyops as subordinated to stratcom and fulfilling the goal of supporting the Alliance's aims, policies, operations and activities, including the strategic narrative. On the other hand, psyops are defined by the same principles as stratcom, especially in terms of attribution, credibility, consistency and truthfulness. It is said that psyops have to be based on true information and preserving Alliance credibility, so they are generally attributable to NATO, a partner nation or organisation. Psyops are also nested within the strategic narrative and overall information strategy. ${ }^{10}$ This understanding might be problematic. Respectively, psychological operations overlap with strategic communication with an emphasis on the narrative. Nevertheless, in contrast to strategic communication, psychological operations may in theory use disinformation and propaganda and may try to manipulate target audiences with false or misleading information. Like propaganda, psychological operations can be divided into white, grey and black psyops based on the source and accuracy of information, and the methods used. White psyops activities are openly acknowledged by the sponsor. Grey ones do not specifically reveal their sources. Black ones deceive about the source, pretending that it is other than the true one. In these terms, psyops are subordinate to the concept of strategic communication (especially with white psyops), but psyops may go well beyond the frame of principles of stratcom and use dirty measures in order to influence a target audience.

Let's come back to understanding information operations and psychological operations in practical terms and consider what consequences might follow. The contradiction in terms of when to apply such operations (peacetime vs. wartime) has already been mentioned. Western democracies believe that such operations should be associated with military operations only. They also believe that deception, disinformation and propaganda should be avoided as tools to be used during operations. The Western approach builds on the belief that carefully developed narratives can only be effective if the messages are reliable and consistent. The approach also counts on the critical thinking of audiences so that the truthful narrative will win ${ }^{\mathbf{1 1}}$. What is more, using disinformation and deception do not theoretically belong in a democracy's peace-time toolbox at all. As a side effect, this approach prevents us from building a comprehensive, complex and functional approach to psyops, which is needed based on our experience with the Eastern approach to this issue.

As we have seen, Russia and China have adopted integrated and holistic approaches, which include information and psychological operations as tools that can be used both in peacetime and during an armed conflict. This approach stands on the belief that strategic advantage can be reached by using non-military means. Non-military means can

10 NATO Standardization Office. Allied Joint Doctrine for Psychological Operations AJP 3-10.1. [online] Brussels: North Atlantic Treaty Organization, NATO Standardization Office, 2014 [cit. 2019-04-30]. Available at: https://assets.publishing.service.gov.uk/government/uploads/system/uploads/ attachment_data/file/450521/20150223-AJP_3_10_1_PSYOPS_with_UK_Green_pages.pdf.

11 BRANGETTO, Pascal, VEENDENDAAL, Matthijs, A. Influence Cyber Operations: the Use of Cyberattacks in Support of Influence Operations. 8th International Conference on Cyber Conflict. Tallinn: NATO CCD COE Publications, 2016. 
allow political or strategic goals to be reached without the conflict being escalated into an armed one and officially recognised as such, thus activating an armed response. Eligible non-military means used might be economic manipulation, disinformation and propaganda, and fostering civil disobedience. Influencing the consciousness of the masses is an aspect of the rivalry between different countries. ${ }^{12}$ Such an approach then exploits the weaknesses of the Western approach.

Another weakness of the current understanding of information and psychological operations is that it overlooks one important target audience - the security and armed forces, i.e. those responsible for protection and defence and for deploying such operations. The current understanding of operations and preparedness for action focuses on four levels according to who is influenced by whom:

1. Own security/armed forces influencing adversary's general public (both information-technical and information-psychological level);

2. Own security/armed forces influencing adversary's security/armed forces (both information-technical and information-psychological level);

3. Own general public being affected by the adversary (both information-technical and information-psychological level);

4. Own security/armed forces being affected by the adversary (only information-technical level).

What is missing here is a notion of the vulnerability of own security/armed forces being the target audience of information and psychological operations at the information-psychological level (i.e. targeting their hearts and minds). That this is the case is demonstrated in the next section.

\section{INFORMATION AND PSYCHOLOGICAL OPERATIONS AGAINST SECURITY/ARMED FORCES}

One well-known example are the psychological and information operations undertaken by ISIS against the security forces of their enemy nations. Examples include a 2015 video recording of the brutal burning of a Royal Jordanian Air Force pilot, Moaz al-Kasasbeh, whose F-16 fighter jet was shot down near the city of Raqqa in Syria. The 22-minute video was published on a Twitter account used by ISIS. The pilot died in flames, locked in a cage. The video was used for propaganda, to send out the threatening message that any soldier fighting against ISIS would die a remorseless death. The video was professionally shot, using multiple cameras and following a script, and complemented

12 MONAGHAN, Andrew. The 'War' in Russia's 'Hybrid Warfare'. Parameters [online]. 45 (4) (inter 20152016), 65-75 [cit. 2019-04-30]. ISSN 0031-1723. Available at: https://ssi.armywarcollege.edu/pubs/ parameters/issues/winter_2015-16/9_monaghan.pdf; RING, A. Teylur. Russian Information Operations and the Rise of the Global Internet. Master Thesis. Washington DC: University of Washington, 2015. 
with sound effects intended to engender fear. Before murdering the pilot, ISIS published an 'interview' with him in its English-language propaganda magazine.

ISIS, or more precisely the 'ISIS Hacking Division', a group linked with it, published personal information of 100 current and past members of the US armed forces. The information included the names, home addresses and photographs of people who fought against ISIS. In its original online appeal, the 'Hacking Division' incited its followers to attack these military personnel, and indeed some people from the list or their family members became targets of verbal attacks on Facebook. But ISIS also called on its sympathisers to track these people to their homes and kill them. Personal information was collected from the internet - specifically, social networks. In response to this incident, the US government appealed to members of its security forces to limit their activities on social networks. The US Marine Corps instructed its members and their families to check their footprint on the internet, to verify the settings of their social networking accounts and to limit the amount of personal information they shared online. So far, the authorities have not sought to ban the use of social networks entirely. The US armed forces have issued instructions on how to use social networks as safely as possible, including advice on blocking access to the user's position, and advised armed forces personnel not to accept friend requests from people they do not know. On the opposite side, ISIS takes an essentially similar position, banning its fighters from using social networks to avoid surveillance from intelligence agencies. In May 2017, ISIS issued an official ban to all its fighters.

Of course, there have been multiple instances of ISIS intimidation on social networks. For instance, the Twitter account of US Command was hacked and the following message posted: 'American soldiers, we are coming, watch your back!'13 The group Gasper CyberCaliphate Sadz hacked the Twitter account of Military Spouses of Strength and sent threats to partners of US soldiers via Twitter and Facebook. The following message was posted on Twitter: 'You think you're safe but IS is already here. \#CyberCaliphate got into your PC and smartphone.' The messages sent to soldiers' wives contained death threats: 'We know everything about you, your husband and your children and we're much closer than you can ever imagine. You'll see no mercy, infidel!'; 'While your president and your husband are killing our brothers in Syria, Iraq and Afghanistan we're coming for you.'14

ISIS (also known as Daesh) has used mobile phones for intimidation, sending text messages to enemy soldiers. For instance, it nearly paralysed the Iraqi army units which were supposed to fight near Mosul in 2014. The message sent to soldiers was, 'Daesh is here'. They were also sent information that ISIS controlled Mosul and had released thousands of extremists from prison. The soldiers were so affected by the campaign that

13 COOPER, Helen. ISIS Is Cited in Hacking of Central Command's Twitter and YouTube Accounts. New York Times [online]. 12 January, 2015 [cit. 2019-04-30]. Available at: https://www.nytimes.com/2015/01/13/ us/isis-is-cited-in-hacking-of-central-commands-twitter-feed.html.

14 MARTINEZ, Michael. Cyberwar: CyberCaliphate targets U.S. military spouses; Anonymous hits ISIS. CNN [online]. 11 February 2015 [cit. 2019-04-30]. Available at: https://edition-m.cnn.com/2015/02/10/ us/isis-cybercaliphate-attacks-cyber-battles/index.html?r=https\%3A\%2F\%2Fedition.cnn. com\%2F2015\%2F02\%2F10\%2Fus\%2Fisis-cybercaliphate-attacks-cyber-battles\%2Findex.html. 
they refused to go further or to obey orders. They literally threw away their uniforms and weapons and deserted.

Psychological and information operations are also known from the ongoing Russo-Ukrainian conflict. As part of its information war, Russia conducts psychological operations against the Ukrainian armed forces, the aim of which is to undermine the morale of Ukrainian soldiers and to spread panic and fear among them. Mobile phones are used for this purpose to send intimidating text messages to Ukrainian armed forces fighting the pro-Russian separatists. This method of conducting psychological operations has been called 'pinpoint propaganda', and can be seen as an updated version of leaflets dropped from aircraft on to enemy territory. The sending of messages has been ascribed to the Russian armed forces, which have an IMSI catcher device at their disposal ${ }^{15}$. Normally, the police and intelligence services use such devices legitimately for the surveillance and apprehension of criminals, but according to Ukraine's cybernetic police, they are employed there for the purposes of psychological warfare. In eastern Ukraine, since 2014 propaganda messages have been sent through the largest Ukrainian mobile services provider, Kyivstar, owned by a Russian company. Examples of such messages include: 'Soldier, if you want to live, go home.' 'Welcome to the Donetsk People's Republic. Your generals are cowards and liars.' 'Your commanders have fled because they know the war is already lost. You're alone and no-one will help you.' ${ }^{16}$ Messages threatening Ukrainian soldiers that they will be killed unless they leave, are not rare either. Similar messages are sent to soldiers' families and friends.

Several investigations into the origin of these messages suggest that Leer-3, a Russian system for electronic combat, is being used in Ukraine and is known to be deployed by Russia in Syria ${ }^{17}$. At a 2016 plenary session of the Organisation for Security and Cooperation in Europe (OSCE) Special Monitoring Mission to Ukraine, the Ukrainian delegation produced evidence of this system's presence in Donetsk ${ }^{\mathbf{1 8}}$.

Last but not least, disinformation and manipulated news can also affect members of the security forces even when they are not themselves the direct target of the disinformation. Many quasi-news websites seek to pose as alternative news sources, often claiming that - unlike mainstream or traditional media - they do not hide 'the truth'. These on-line media report on domestic and international events, and often offer what they call an 'alternative explanation of reality' or 'alternative facts' (which, of course, is

15 CHIRGWIN, Richard. Someone is sending propaganda texts to Ukrainian soldiers. The Register [online]. 2017 [cit. 2019-04-30]. Available at: https://www.theregister.co.uk/2017/05/12/ someone_is_sending_propaganda_texts_to_ukranian_soldiers/.

16 KOPOTIN, Igor, SAZONOV, Vladimir. Russia's Information Warfare against Ukraine II: Influences on the Armed Forces of Ukraine [online]. Estonian National Defence College, 2015 [cit. 2019-04-30]. Available at: http://www.ksk.edu.ee/wp-content/uploads/2017/11/RUSSIA-\%E2\%80\%99S-INFORMATION-WARFAREAGAINST-UKRAINE-II-koolon-INFLUENCES-ON-THE-ARMED-FORCES-OF-UKRAINE.pdf.

17 DFRLab. Electronic Warfare by Drone and SMS: How Russia-backed separatists use 'pinpoint propaganda' in the Donbas. Medium [online]. 2017 [cit. 2019-04-30]. Available at: https://medium.com/dfrlab/ electronic-warfare-by-drone-and-sms-7fec6aa7d696.

18 OSCE. Statement by the Delegation of Ukraine at the 822nd FSC Plenary Meeting [online]. 2016 [cit. 201904-30]. Available at: https://www.osce.org/fsc/252856?download=true. 
a logical impossibility). Some of these media are directly state-orchestrated (for example, Russia's RT and Sputnik); others are independent of states but directed by people who support the geopolitical, security, civilisational etc. interests of other powers, or they simply prefer the worldviews of these powers to those offered by the West. Ideologically, they are closer to conservative, nationalist and authoritarian views than to liberalism and democracy. Their online disinformation works on the same principle, customising their interpretations of domestic and world events to the values of readers who tend to be anti-EU, anti-NATO and often right-wing. They also skilfully work with their readership's emotions and, through eliciting various sentiments, manipulate their opinions. Principles of cognitive dissonance and cognitive bias play an important role in this. A 2017 study by experts of the Indiana University School of Informatics and Computing shows that it does not matter whether the information given is provided by fact-checked or low-credibility articles (or even pieces of outright disinformation). Both types have the same chance of success with non-biased audiences ${ }^{19}$. We already have preconceived opinions on the bulk of the information we receive. Theories of cognitive dissonance and cognitive bias say that people have a natural tendency to accept information that upholds their position and keeps their behaviours in harmony, i.e. does not cause dissonance or inner tension. This leads us to false reasoning and decisions and the faulty remembering of information. We naturally tend to choose information that confirms our opinions. Members of the security/armed forces are as vulnerable as the population at large.

Besides already existing tools affecting the security/armed forces we can expect in the near future threats connected with artificial intelligence and machine learning processes. These might newly affect not only security/armed forces, but the general public as well. One of them might be madcom (machine-driven communication). Madcom refers to a state where artificial intelligence offers a multitude of tools and ways to manipulate the human mind, integrating artificial intelligence systems into robotic propaganda tools. This propaganda is then spread by an automated profile on social networks. By using sophisticated algorithms, this profile may produce its own content. ${ }^{20}$ The development of madcom is expected to improve so-called chatbots. A chatbot (or also a chat robot) is a computer program designed for automated communication that asks people questions based on a predefined scenario. Chatbots have already been used in e-shops, and in communication applications such as Messenger and Skype. They communicate with clients in order to process online order returns or they help in choosing a product. With a set of questions, the chatbot finds out what the customer is interested in and redirects him or her to the product/manual. It is also expected that in the near future chatbots will learn to produce dynamic content based on psychological user profiling.

Above all, the security threats associated with madcom are that it is a tool that has the potential to spread highly personalised propaganda and disinformation

19 SHAO, Chengcheng et al. The spread of low-credibility content by social bots. Nature communications [online], 2018 [cit. 2019-04-30]. ISSN 2041-1723. Available at: https://www.ncbi.nlm.nih.gov/pmc/ articles/PMC6246561/. 
campaigns - based on information about the recipient. These will be personalised based on information about our activities in the virtual space, and on information we might share in the virtual space about family and friends, political preferences, demographic data and hobbies. Madcom tools will be able to come up with a very convincing and manipulative form of communication, able to target our vulnerabilities and detect our emotions in real time.

A newly discussed threat is also presented by deep fakes, which consist of audio or video of real people appearing to say or do things they never actually said or did. Originally, deep fake technology was used in the porn industry - faces of famous people were added into pornographic films. Replacing one person's face with another's using hyperrealist digital technology is a very accomplished illusion, based on deep machine learning. Beyond learning a person's movements and expressions, the machine also clones their voice and can make them appear to say anything - even words that the artificial intelligence had not learned directly. This technology has been marketed by companies such as Baidu, iSpeech and Lyrebird, which offered it for commercial purposes (for example, for human-machine interfaces). The Siri and Alexa digital assistants provide a generally known example of cloning a voice using machine learning.

There are a number of threats implied by the abuse of deep fake technology and the security risks are very high. Deep fakes exploit the same cognitive processes (and their weaknesses) as disinformation. They rely on the same processes of receiving information as any other communication and we can say that deep fakes are more dangerous than text, as we are more likely to believe video than text. Video seems naturally to guarantee the trustworthiness of information and are commonly used as proof that particular utterances were made. One question is: what will happen to video and audio material as evidence in judicial processes? To top it all, machine learning makes deep fake a technology that is very difficult to detect.

Bobby Chesney and Danielle Citron ${ }^{21}$ identified several possible negative effects from deep fakes. Individuals and organisations, they say, might be abused, blackmailed or sabotaged. Nearly anyone could be blackmailed using a deep fake - whether for money, trade secrets, or any other information of a sensitive nature. Only a few hundred photographs of the person from social networks are needed to create a convincing video. Deep fake video depicting Barack Obama speaking about the dangers of disinformation needed 56 hours of recordings in order to create a plausible simulation of the ex-president's voice ${ }^{22}$. Deep fakes could also be used to falsely associate a person with another person, product, service or idea - an association that might not happen in the real world.

Deep fakes and other tools based on machine learning may damage not just people and legal entities; they may even have a very negative impact on society itself. Based on the analysis of Chesney and Citron, we can identify these threats, some of them very relevant in the context of vulnerability or resilience of security/armed forces:

21 CHESNEY, Bobby, CITRON, Danielle. Deep Fakes: A Looming Challenge for Privacy, Democracy, and National Security. SSRN Electronic Journal, 2018. ISSN 1556-5068.

22 Bloomberg. How Faking Videos Became Easy - And Why That's So Scary. Fortune [online]. 11 September 2018 [cit. 2019-04-30]. Available at: http://fortune.com/2018/09/11/deep-fakes-obama-video/. 
1) Disruption of democratic discourse and of trust in institutions

A substantial volume of disinformation damages democracy, aiming to undermine trust in the democratic system, consisting of political institutions and constitutional and political officials. Disinformation narratives seek to create the impression that political representatives betray their voters and misgovern, or to create an atmosphere where everyone lies and nobody can be trusted. Deep fakes will only make matters worse. Let us imagine, for instance, deep fake video or audio capturing law enforcement officials discussing possible ways of abusing their powers.

\section{2) Manipulating elections}

Disinformation plays a very conspicuous role at times of elections, entering the public discourse with increased frequency and aiming to influence the voters and outcome of the elections.

\section{3) Artificial increase of conflict in society}

It can be expected that this technology will be abused to increase or escalate tensions between various groups in the population, be they social, ethnic or religious. False information about the migration crisis, terrorist attacks in Europe (or Czechia) or support for radical Islam, are some obvious examples. For instance, let us imagine a deep fake video of a Muslim who in a Czech mosque openly supports ISIS or another terrorist organisation, and the possible consequences of such a video going viral.

\section{4) Dangers to public security}

Conflicts in society are only a small step away from dangers to public security. It is very easy to create panic with a gunshot, and a deep fake can work similarly in the virtual word (and from there, of course, such panic may be transferred into the real world). In the least harmful scenario, the panic creates financial damage; in the worse case, damage to property, accidents or deaths. Chesney and Citron ${ }^{\mathbf{2 3}}$ cite an example of intentional disinformation issued by a Russian research agency, which claimed that there had been a chemical disaster in Louisiana and an Ebola outbreak in Atlanta. The real damage caused by this disinformation was ultimately minimal, as both stories lacked proof and the facts were easy to verify. However, deep fake video and audio materials can potentially substantially improve the plausibility of disinformation.

\section{5) Undermining diplomacy}

Deep fakes could also seriously disrupt diplomatic relations. Words could be put in the mouths of political representatives that have never been uttered. Pressure could then be created to respond rapidly, causing damage in international relations and increasing the likelihood of a conflict breaking out. International relations could be disrupted by

23 CHESNEY, Bobby, CITRON, Danielle. Deep Fakes: A Looming Challenge for Privacy, Democracy, and National Security. SSRN Electronic Journal, 2018. ISSN 1556-5068. 
the publication of a video on the internet of army officers committing war crimes during their mission abroad.

\section{6) Dangers to national security}

The use of deep fakes to create danger to public security and to disrupt international relations can be thought of as threats to national security. We have encountered well developed propaganda from Daesh and the successor to Daesh might use deep fakes to create an 'alternative reality' in which their own fighters are strong and invincible. By contrast, armies or intelligence services might come under political or public pressure demanding the curtailing of their powers and greater control over them. This might happen when audio or video materials are published purporting to show that army or intelligence agency had abused their powers.

\section{CONCLUSIONS AND RECOMMENDATIONS}

Information and psychological operations are powerful instruments of warfare. Nevertheless, as has been demonstrated information and psychological operations have also become important instruments during peacetime and they have become a crucial part of what is called hybrid warfare, irregular warfare or asymmetric conflict (as the reader wishes). However, the Western /NATO military think about information and psychological operations in their own way in contrast to their Eastern equivalents, which have a more holistic and complex view. The Western thinking is more military-operations-focused, associating information operations exclusively with military operations. With psychological operations it is even more complicated. Psyops are here to support the aims of military operations, i.e. they are related to military affairs. Nevertheless, it is also said that psyops mean purposeful psychological influencing of target groups, carried out in peace and in wartime. Psyops play the role of a sub-category, but they also overlap with information operations. Based on this less-than-exact definition of mutual relations, and also due to the realities of conducting hybrid warfare (under the threshold of what is officially recognised as armed conflict, and preferring non-military tools) by a variety of state and non-state actors, the redefinition of information operations should be discussed in terms of expanding the definition in peacetime.

Also psyops deserve terminological redefinition so that they do not overlap with strategic communication, or are not narrowed down to white psyops only. The current definition reflects the democratic approach, which says that covert actions, deception and propaganda do not belong in the toolbox of democracies. Such an approach prevents us from being able to react to the toolbox of our adversaries, who do not apply the same approach. We do not need to be afraid that the redefinition means a green light for democracies to use such tools. It just creates space for better understanding our adversaries and for developing counter-measures.

Last but not least, as was demonstrated in the article, defence and security establishments should also react to the existing vulnerability of our own security/armed forces at the information-psychological level. In military affairs, a lot of attention is paid 
to the information-technical level, but not necessarily enough is paid to the information-psychological level. We should be aware that it is not only the general public, but also military and security staff who are vulnerable and recognised as potential targets to be psychologically influenced by adversaries. Since psyops exploit fear, play with emotions and the cognitive dimension, it is necessary to build resilience also in this area.

Author: $\quad$ Petra Vejvodová, PhD., born 1984, works as assistant professor at the Department of Political Science of the Faculty of Social Studies, Masaryk University, and since 2016 has been the head of Security and Strategic Studies. She graduated in political science and international affairs at the Faculty of Social Studies. Her doctoral studies were successfully finished in 2014 with her PhD thesis on international cooperation of European neo-Nazis. In her research, she focuses on political extremism and radicalism in Europe, security policy, information warfare, propaganda and disinformation campaigns. Petra is author and co-author of multiple research papers. She is also a member of the Radicalisation Awareness Network and the European Expert Network on Terrorism Issues.

How to cite:VEJVODOVÁ Petra. Information and Psychological Operations as a Challenge to Security and Defence. Vojenské rozhledy. 2019, 28 (3), 083-096. ISSN 1210-3292 (print), 2336-2995 (on-line). Available at: www.vojenskerozhledy.cz 
Recenzovaný článek

\section{Analýza a model systému přípravy odborníků kybernetické obrany}

\section{Analysis and model of Cyber security corps professional development}

\section{Petr Františ, Jan Hodický}

Abstrakt: Článek se zabývá problematikou prípravy odborníků v oblasti kybernetické bezpečnosti. $V$ úvodu jsou popsány jednotlivé prvky, které působí v oblasti kybernetické bezpečnosti. Dále je provedena strategická analýza popisující východiska v oblasti vzdělávání. Stěžejní část práce je věnována návrhu systému vzdělávání. $V$ práci jsou definovány jednotlivé prvky a je vytvořen model vztahů těchto prvků. $\vee$ př́loze je uveden kompletní výčet témat a jejich rozčlenění dle úrovní znalostí pro specialistu kybernetické bezpečnosti.

Abstract: The paper deals with the professional development of cyber security corps. In the introduction the individual elements that are active in cyber security are described. Strategic analysis of the education is carried out to define the initial state. The main part of the paper is devoted to the design of the education system. The individual elements are defined in the paper, and the model of relationships between these elements is shaped. The attachment contains complete set of topics and their classification into the strands to fulfil the profile of the cyber security expert.

Klíčová slova: Kybernetická bezpečnost; modelování; vzdělávání.

Key words: Cyber defense; Modelling; Education. 


\section{ÚVOD}

Vize AČR je v oblasti kybernetické obrany teprve v procesu přípravy. Ze své podstaty bude vycházet z dokumentu „Koncepce výstavby AČR 2025“1. Tento dokument definuje základní východiska a předpokládaný stav AČR v roce 2025. Oblast kybernetické bezpečnosti je zmíněna v následujících souvislostech:

„Armáda ČR bude mít, v součinnosti s orgány odpovědnými za kybernetickou bezpečnost a obranu, schopnosti plánování a rrízení operací v kybernetickém prostoru a schopnost vytvářet související krizové plány."

Kybernetická obrana a kybernetická bezpečnost je dle Národní strategie kybernetické bezpečnosti pro období let 2015 - 2020, definovány následovně2:

- Kybernetická obrana, kterou má v gesci Vojenské zpravodajství, je samostatnou oblastí širšího konceptu kybernetické bezpečnosti a zároveň oblastí širšího konceptu zajištění obrany státu. Jejím úkolem je v případě potřeby aktivně působit v kybernetickém prostoru proti útočníkům. Specifikem kybernetické obrany je skutečnost, že bude prováděna jak v případě vyhlášení mimořádných stavů, především formou součinnosti s ostatními složkami zajištujuícími obranu ČR, tak i nepřetržitě mimo tyto stavy.

- Kybernetickou bezpečnost má v České republice v gesci Národní úřad pro kybernetickou a informační bezpečnost. Jeho úkolem je neustálé navyšování bezpečnosti a odolnosti informační a komunikační infrastruktury. Kybernetickou bezpečností se tedy rozumí souhrn prostředků směřujících k zajištění ochrany kybernetického prostoru. Tyto prostředky mohou být různého charakteru - právní, organizační, vzdělávací, technické a další ${ }^{3}$.

V kontextu systému vzdělávání termín kybernetická obrana, jehož ekvivalent je v NATO termín Cyber Defense, zahrnuje pasivní prostředky kybernetické bezpečnosti (Cyber Security) a aktivní prostředky obrany4.

Členství České republiky v Severoatlantické alianci významně ovlivňuje výchovně vzdělávací proces. Podstatou procesu obraného plánování NATO je identifikace a tvorba potřebného rámce schopností $k$ vedení předpokládaných operací krizového řízení v souladu s politicko-vojenskými ambicemi. Tyto požadavky na schopnosti, které NATO definuje a požaduje po jednotlivých členských státech, jsou v souladu s plánovacím procesem v NATO upřesňovány každé čtyři roky.

1 Ministerstvo obrany. Koncepce výstavby Armády České Republiky 2025. Praha : Ministerstvo obrany, 2018.

2 Národní centrum kybernetické bezpečnosti (2015a): Národní strategie kybernetické bezpečnosti. Dostupné z: https://www.databaze-strategie.cz/cz/cr/strategie/ narodni-strategie-kyberneticke-bezpecnosti-cr-na-obdobi-let-2015-az-2020?typ=struktura.

3 Riethofová, Mgr. Alžběta. Informační servis. www.moccr.army.cz. [Online] 6. 82018. http://www.mocr.army.cz/informacni-servis/zpravodajstvi/narodnicentrum-kybernetickych-operacivypracovalo-strategii-kyberneticke-obrany-cr-201906/.

4 Feix, Miroslav a Procházka, Dalibor. Aktuální úkoly kybernetické obrany rezortu Ministerstva obrany. Vojenské rozhledy. 2017, Sv. 3. 
Oblasti kybernetické obrany se týká schopnost E 6202 N: CYBER DEFENCE, kde v části 3 je uveden požadavek: „Vzdělávání, výcvik a dovednosti v oblasti kybernetické bezpečnosti".

Základní reakcí na tento požadavek je vytvoření a akreditování studijního programu Kybernetická bezpečnost na Univerzitě obrany, který pokrývá především oblast technických specializací. I když obsahuje část tzv. měkkých dovedností (soft skills), tak majoritně je zaměřen na aplikaci bezpečnosti v prostředí informačních technologií, tedy potřeby AČR - AKIS (CIRC). V předmětové skladbě Ize nalézt předměty, jako jsou Analýza informačních zdrojů, Vývoj a nasazen malware, Botnetové sítě, které pokrývají část potřeb VZ NCKO.

Výhoda tohoto studijního programu je jeho ucelený průběh - 5 let nepřetržitého studia, tedy nedochází ke zbytečné ztrátě času zpracováním a obhajobou bakalářské práce a navazujících státních zkoušek. Rovněž tak časové schéma průběhu studia poskytuje dostatek času na odborné praxe, které v posledních dvou letech studia mohou probíhat již na pracovišti, kde bude student po skončení studia zařazen.

Vytvořením a úspěšnou akreditací tohoto studijního programu Univerzita obrany položila dobrý základ ke vzdělání specialistů v oblasti kybernetické obrany pro rezort MO.

\section{CÍlE A STANOVENÉ OKRUHY PROBLÉMŮ}

Hlavním cílem tohoto článku je navrhnout systém vysokoškolského vzdělávání problematiky kybernetické obrany v resortu MO. Samotná existence akreditovaného programu ovšem ještě nevytvárí ucelený systém přípravy odborníků kybernetické obrany. Pro dosažení stanoveného cíle článku byly stanoveny následující výzkumné otázky/ oblasti problému.

Jací vnitřní a vnější aktéři ovlivňují problematiku přípravy personálu v resortu MO v oblasti kybernetické obrany?

Jaké jsou vzájemné vazby definovaných aktérů kybernetické obrany v kontextu př́pravy personálu resortu MO?

Jaká témata musí být součástí systému přípravy personálu resortu MO v oblasti kybernetické obrany?

\section{METODY A DATA}

Pro nalezení odpovědí na otázky stanovené v kapitole 2 byla použita analýza činnosti a působnosti jednotlivých aktérů v oblasti vzdělávání problematiky kybernetické obrany. Pro definování východiska stávajícího stavu vzdělávání byla použita strategická analýza, ale pouze její část, která rozkrývá vnitřní a vnější aktéry a definuje př́ležitosti a hrozby spojené s vnějším okolím vzdělávání. Následně bylo použito modelování na systémové 
úrovni ${ }^{5}$, které popsalo vazby mezi jednotlivými složkami systému vzdělávání. Grafická reprezentace modelu vazeb mezi složkami vzdělávacího systému byla vytvořena v podobě mentální mapy 6 . Participativní metoda panelu expertů, složeného z 35 . účastníků kurzu Generálního štábu (KGŠ) 2018-2019, byla použita pro stanovení výčtu témat a jejich členění do dílčích úrovní znalostí a směrů pro přípravu odborníků specializace kybernetické bezpečnosti. Tyto informace jsou obsaženy $v$ př́loze článku. KGŠ byl zvolen z důvodu strategického dopadu nové domény.

\section{AKTÉŘI V OBLASTI VZDĚLÁVÁNÍ PROBLEMATIKY KYBERNETICKÉ OBRANY}

Tato kapitola popisuje významné složky státu působící v oblasti kybernetické obrany a jejich vztah ke vzdělávání odborníků v této oblasti. Jedná se o složky, které mají vztah k rezortu MO a zasahují do vzdělávání specialistů v oblasti kybernetické obrany.

\subsection{Národní úřad pro kybernetickou a informační bezpečnost (NÚKIB)}

Národní úřad pro kybernetickou a informační bezpečnost je ústředním správním orgánem pro kybernetickou bezpečnost včetně ochrany utajovaných informací v oblasti informačních a komunikačních systémů a kryptografické ochrany. Dále má na starosti problematiku neveřejné služby v rámci družicového systému Galileo. Vznikl 1. srpna 2017 na základě zákona číslo 205/2017 Sb., kterým se změnil zákon č. 181/2014 Sb., o kybernetické bezpečnosti a o změně souvisejících zákonů (zákon o kybernetické bezpečnosti) ${ }^{7}$. I když tento úřad není součásti resortu $\mathrm{MO}$, tak významně ovlivňuje a formuje požadavky na vzdělávání v oblasti kybernetické obrany.

\subsection{Národní centrum kybernetických operací (NCKO)}

Národní centrum kybernetických operací je součást Vojenského zpravodajství. Bylo ustanoveno na základě Akčního plánu k Národní strategii kybernetické bezpečnosti pro

5 Frevert, R., Haase, J., Roland, J., Knöchel, U., Schwarz, P., Kakerow, R., Mohsen R. (2005). System Level Modeling. Modelling and Simulation for RF System Design. 10.1007/0-387-27585-1_4.

6 Eppler, M. J. (2006). A Comparison between Concept Maps, Mind Maps, Conceptual Diagrams, and Visual Metaphors as Complementary Tools for Knowledge Construction and Sharing. Information Visualization, 5(3), 202-210. https://doi.org/10.1057/palgrave.ivs.9500131.

7 NÚKIB. Úvod. Národní úřad pro kybernetickou a informační bezpečnost. [Online] 2018. [Citace: 24. 10 2018.] https://www.govcert.cz/. 
období let 2015 - 2020. Jeho úkolem je vytvoření účinného systému obrany v kybernetickém prostoru tak, aby Česká republika byla schopna zastavit a prípadně odvrátit kybernetické útoky, a tím zabezpečit ochranu civilního obyvatelstva a infrastruktury ${ }^{8}$. Národní centrum kybernetických operací vypracovalo Strategii kybernetické obrany ČR 2018 - 2022, která obsahuje nastavení právního rámce, vybodovaní a rozvoj infrastruktury a schopnosti obrany v kyberprostoru.

\subsection{Centrum Computer Incident Response Capability (CIRC)}

Centrum CIRC je organizačním prvkem Agentury komunikačních a informačních systémů (AKIS) a prvkem kybernetické bezpečnosti s působností pokrývající celý resort MO. Úkolem Centra CIRC je proaktivní identifikace bezpečnostních hrozeb a incidentů pomocí nepretržitého monitoringu důležitých segmentů datových sítí resortu $\mathrm{MO}$, a jejich následná analýza, vyhodnocování a reportování relevantním partnerům ${ }^{9}$. Mezi další úkoly centra CIRC patří šiřrení bezpečnostního povědomí mezi uživateli a správci informačních a komunikačních systémů.

\subsection{Odbor bezpečnosti Ministerstva obrany}

Odbor bezpečnosti Ministerstva obrany odpovídá za plnění úkolů stanovených zákonem č. 412/2005 Sb., o ochraně utajovaných informací a o bezpečnostní způsobilosti, zákonem č. 181/2014 Sb., o kybernetické bezpečnosti a o změně souvisejících zákonů (zákon o kybernetické bezpečnosti), a zákonem č. 499/2004 Sb., o archivnictví a spisové službě a o změně některých zákonů. Odpovídá za nastavení systému řizení bezpečnosti informací včetně kontroly jeho dodržování, ochrany určených neutajovaných informací a kybernetické bezpečnosti v rezortu Ministerstva obrany. Včele odboru bezpečnosti stojí Bezpečnostní ředitel Ministerstva obrany. Bezpečnostní ředitel, kromě jiných povinností, zastává funkci předsedy Rady pro kybernetickou obranu Ministerstva obrany ${ }^{10}$.

\subsection{Sekce rozvoje sil MO}

Sekce rozvoje sil Ministerstva obrany odpovídá za koncepční činnosti a za odborné a metodické rízení výstavby a rozvoje pozemních sil, vzdušných sil, schopností Armády

8 NCKO. Kybernetická obrana. Vojenské zpravodajství. [Online] 2018. [Citace: 24. 10 2018.] https://vzcr.cz/kyberneticka-obrana-46.

9 7. CIRC. O nás. Centrum CIRC. [Online] 2009. [Citace: 24. 10 2018.] http://www.circ.army.cz/onas.

10 Ministerstvo obrany. Organizační raád Ministerstva obrany. [Dokument] Praha : autor neznámý, 2018. 
České republiky v kybernetickém prostoru, vojensko-civilní spolupráce (CIMIC - Civil-Military Cooperation), psychologických operací (působení) v místě nasazení (PsyOps - Psychological Operations) a záchranné a výsadkové služby Armády České republiky. Odpovídá za koncepční činnosti a za odborné a metodické řízení systému velení a řízení, za stanovování zásad a norem v oblasti společné prípravy pozemních sil a vzdušných sil, záchranné a výsadkové služby, služby pátrání a záchrany v Armádě České republiky. Koordinuje proces udržení a rozvoje schopností Armády České republiky. Dále odpovídá za zpracování Doktríny Armády České republiky. Zajištuje plnění úkolů služebního orgánu odpovědného za vojenské odbornosti v odborné gesci ředitele sekce rozvoje sil Ministerstva obrany je zodpovědná za obsah programů prípravy schopností Armády České republiky v kybernetickém prostoru ${ }^{11}$.

\subsection{Velitelství kybernetických sil a informačních operací}

Velitelství kybernetických sil a informačních operací vzniklo dne 1. ledna 2018. Vytvoření tohoto velitelství symbolizuje, že Armáda České republiky zařadila kybernetickou doménu na taktický stupeň velení a dále počítá s jejím plným rozvinutím o podřizené prvky. Mezi jeho základní úkoly patří velení a řizení podřízených útvarů kybernetických sil a informačních operací, plánování a řízení působení v kybernetickém prostoru, plánování a řízení informačních operací ${ }^{12}$.

\section{STRATEGICKÁ ANALÝZA VZDĚLÁVÁNÍ V OBLASTI KYBERNETICKÉ OBRANY}

V této kapitole je provedena strategická analýza problematiky vzdělávání v oblasti kybernetické obrany v rezortu Ministerstva obrany. Výsledky strategické analýzy slouží pro popis stávajícího stavu prípravy odborníků a k vymezení vnitřního a vnějšího okolí dané problematiky. Celkově strategická analýza prissívá ke stanovení východisek pro návrh jednotlivých částí systému prípravy, nebylo tedy s ní dále pracováno ve smyslu návrhu strategie, nebo úpravy již existujících strategií vzdělávání odborníků kybernetické obrany.

\subsection{Silné stránky vzdělávání v kybernetické bezpečnosti}

- Akreditovaný studijní program „Kybernetická bezpečnost na UO“

11 SRS MO.Sekce rozvoje sil MO. [Online] 2018. [Citace: 24.102018.$]$ http://www.acr.army.cz/struktura/generalni/rozvoj/sekce-rozvoje-sil-mo-142358/.

12 9. Feix, Miroslav. Působnost VeKiS. Praha: GŠ AČr, 2018. 
- Vznik Velitelství kybernetických sil a informačních operací

- Postoj Vlády České republiky ke kybernetické bezpečnosti vyjádřen v dokumentu: „Národní strategie kybernetické bezpečnosti České republiky na období let 2015-2020"

- Umístění NÚKIB, NCKO, CIRC, VeKySIO ve stejném městě

\subsection{Slabé stránky vzdělávání v kybernetické bezpečnosti}

- Personální nenaplněnost,

- Objekt centra NCKO byl nedávno dokončen, ale nezačal ještě pracovat v novém místě

- VelKysı formálně vzniklo, ale není personálně dostatečně naplněno (až k 1.7),

- Nejsou zpracované všechny potřebné dokumenty (vize a strategie kybernetické obrany AČR)

- Kvalifikovaný personál odchází i se znalostmi do civilní sféry,

- Není spolupráce v oblasti vzdělávání a předávání znalostí mezi všemi složkami.

\subsection{Př́ležitosti vzdělávání v kybernetické bezpečnosti}

- NÚKIB je umístěn ve stejném městě v docházkové vzdálenosti od UO, VelKysIO a NCKO

- Blízkost Masarykovy univerzity a jejího kybernetického polygonu

- Brno je studentské město a centrum technologických firem působících v oblasti IT

- Oblast Kybernetické obrany je akcentována za strany vlády a existuje široká podpora, výzkumných projektů a záměrů v této oblasti.

\subsection{Hrozby vzdělávání v kybernetické bezpečnosti}

- Ztráta důvěry státní správy ve schopnosti složek Ministerstva obrany kvalifikovaně působit v oblasti kybernetické obrany

- Kompromitace schopností zásadním kybernetickým útokem na infrastrukturu Ministerstva obrany a jejích složek

- Lobbing civilních vzdělávacích institucí proti schopnostem vzdělávat odborníky v oblasti kybernetické obrany uvnitř rezortu Ministerstva obrany za účelem získání státních prostředků pro jejich vlastní financování 


\subsection{Analýza vnitřního prostředí}

Z hlediska vnitřního prostředí jsou poměrně jasně definovány silné stránky. Základem je postoj Vlády České republiky, která schválením strategických dokumentů umožnila vznik důležitých center v rámci vládních úřadů a bezpečnostních složek, které se zabývají problematickou kybernetické bezpečnosti a obrany. Tento postoj se promítl i do AČR, která zareagovala vytvořením př́ślušných složek a změnou kompetencí a struktury již existujících složek. Z hlediska vzdělávání zareagovala Univerzita obrany vytvořením nového studijního programu „Kybernetická bezpečnost“. Z pohledu slabých stránek je nejpalčivějším problémem personální situace. Je to zejména nedostatečný přísun vzdělaného personálu, odchod kvalifikovaného personálu a chybějící spolupráce mezi složkami. Zejména odchod kvalifikovaného personálu je velkým problémem. Řešení na jeho zmírnění je v kompetenci resortu $\mathrm{MO}$ a jeho personální a finanční politiky, tedy principiálně mu nelze zabránit, ale Ize alespoň zmírnit jeho následky tím, že zabráníme odlivu znalostí spolu s odlivem personálu. Důležité je vytvořit zpětnou vazbu pro uložení znalostí, které jsou ukryté v kvalifikovaném personálu a vrátit je nazpět do vzdělávacího systému.

Dalším problémem je malé sdílení schopností a informací mezi hlavními složkami státu v oblasti kybernetické obrany- Výměna informací probíhá převážně na manažerskostrategické úrovni. $Z$ hlediska legislativy není možné sdílení na úrovni operačně taktické, ale bylo by vhodné vytvořit lepší podmínky pro sdílení znalostí a kapacit na úrovni vzdělávací a umožnit tak větší propojení těchto složek do vzdělávacího systému.

\subsection{Analýza vnějšího prostředí}

Velkou roli v oblasti př́ležitostí hraje geografická lokace všech zásadních institucí působících v oblasti kybernetické obrany. Umístění těchto složek v městě Brně je výrazně pozitivním prvkem pro jejich vzájemnou integraci a provázanost. Zároveň pozice města Brna jako centra vysokých škol a firem působících v IT (technologický park) a Univerzity obrany vytváŕi vhodné podmínky pro nábor odborného personálu. Geograficky umístění $v$ centru Moravy a díky dobrému spojení a kapacitě infrastruktury je Brno vhodným městem pro denní dojíždění za prací z moravských měst a vesnic. To vše by mělo pozitivně ovlivnit dobrou personální situaci a propojení vzdělávání a výměnu informací. $Z$ hlediska hrozeb se jako nejvážnější jeví zkompromitování systému vzdělávání na základě vnějšího kybernetického útoku na nějakou část státní infrastruktury, který by mohlo vést ke zkratkovité interpretaci v médiích jako selhání systému přípravy dostatečně kvalifikovaných odborníků. To by mohlo vyústit $k$ necitlivému zásahu do systému vzdělávání na základě politických rozhodnutí. Zbylé hrozby jsou spíše minoritní. 


\section{NÁVRH SYSTÉMU VZDĚLÁVÁNÍ ODBORNÍKŮ KYBERNETICKÉ OBRANY}

Tato kapitola je stěžejní po obsahové stránce a popisuje vertikální a horizontální členění navrženého systému vzdělávání a dále obsahuje model vazeb aktérů v tomto systému.

Na základě panelu expertů, složeného z účastníků kurzu Generálního štábu 20182019, je doporučeno jednotlivá témata rozdělit do čtyř úrovní a z pohledu odbornosti do dvou směrů:

- Technicky zaměřená témata

- Manažersky zaměřená témata

Do základní úrovně lze zařadit témata, která by měla být součástí magisterského stupně vzdělávání, např.:

- Analýza paměti

- Senzorové sítě

- Operační systémy

První úroveň má charakter specializace. Zahrnuje témata, která rozšiřují základní IT vzdělání a mohou nebo nemusí být i součástí specializovaného magisterského studijního programu, např:

- Základní informace o malware

- Získávání dat z otevřených zdrojů

- Krizová zákon

Druhá úroveň obsahuje více specializovaná témata týkající se převážně kybernetické bezpečnosti (defensivní schopnosti), např.:

- Regulace v kyberprostoru

- Nakládání s daty jako důkazním materiálem

- Data pro řešení incidentu

Témata třetí úrovně se týkají ofensivních schopností a vysoce specializovaných znalostí a dovedností, např.:

- Kyberšikana, kyberstalking

- Vývoj vlastních exploitů

- Vývoj nástrojů pro zahlazení identit

Kompletní výčet témat a jejich rozčlenění dle úrovní výstupních znalostí a specializačních směrů je uveden v př́loze článku.

\subsection{Vertikální členění systému vzdělávání}

Úrovně jednotlivých témat přirozeně určují vertikální skladbu vzdělávání. Spodní úroveň je tvořena základním magisterským vzděláním a postupně jsou na tuto spodní úroveň přidávány jednotlivé vrstvy, které jsou tvořeny specializovanými kurzy. Z každé vrstvy odchází specialisté, kteří dosáhli dané úrovně dostatečné pro svoje specializované místo a pracoviště. Tedy množství lidí se v jednotlivých úrovních zmenšuje, viz obrázek 1. 


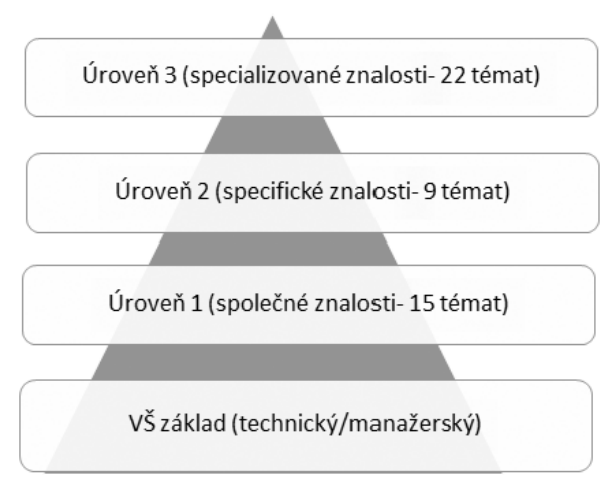

Obrázek č. 1: Vertikální členění systému vzdělávání

Kurzy první a druhé úrovně by měli být přizpůsobeny tak, aby se jejich absolventi rozdělili a získali potřebné znalosti a dovednosti v následujících směrech:

- bezpečnostní testování.

- správa sítě

- forenzní zkoumání

- vývoj a analýza software

- manažer kybernetické bezpečnosti

- odborník na kybernetické politiky (Cyber policies)

Kurzy třetí úrovně jsou již úzce specializované a spojené s odborností daného pracoviště, na kterém absolventi působí.

\subsection{Horizontální členění systému vzdělávání}

Na témata kybernetické obrany lez nahližet také z hlediska jejich odborné př́slušnosti $\mathrm{k}$ jednotlivým složkám působící v prostředí kybernetické obrany. Tím Ize získat pohled charakterizující co je pro jednotlivé složky společné a co jedinečné, viz obrázek 2. 


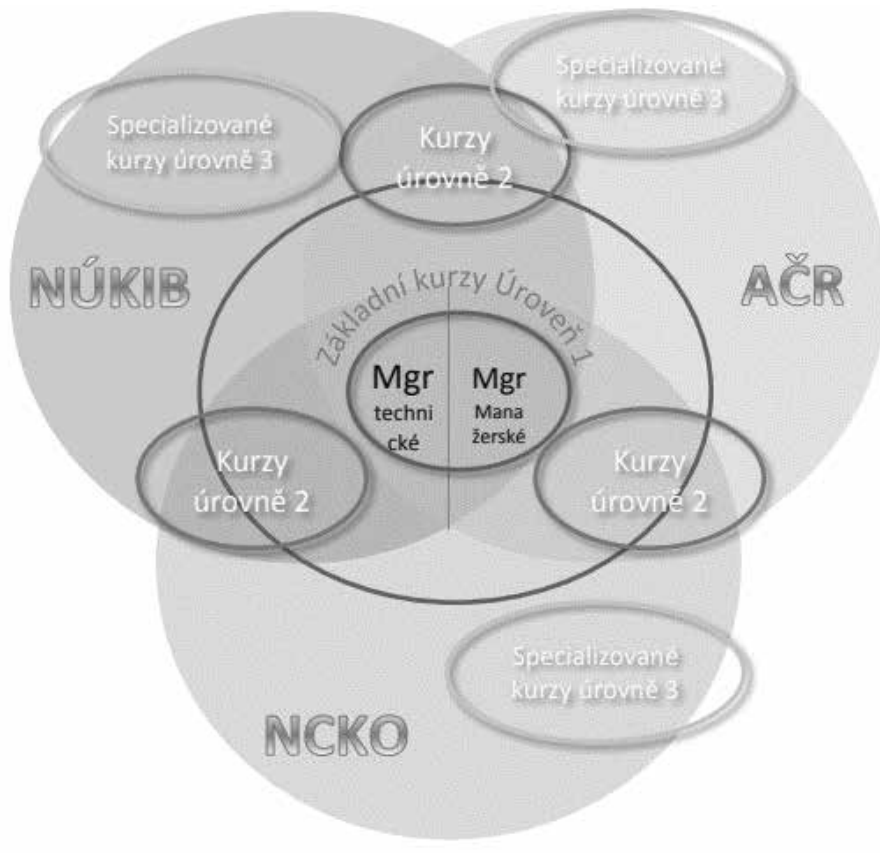

Obrázek č. 2: Horizontální členění systému vzdělávání

Z uvedeného schématu je vidět, jakým způsobem jednotlivé kurzy pokrývají společné potřeby znalostí a dovedností. Při pohledu na toto schéma z hlediska znalostí Ize rozpoznat, že jeho všechny části tvoři uzavřený ekosystém. Tento ekosystém je tvořen všemi potřebnými znalostmi a dovednostmi. Únik těchto znalostí a dovedností je způsoben odchodem kvalifikovaného personálu. Pro udržení znalostí a dovedností uvnitř ekosystému je nutné pracovat se systémem zpětných vazeb. Důvody využití těchto zpětných vazeb a úniku znalostí byly popsány v kapitole zabývající se analýzou vnitřních slabých stránek systému vzdělávání. Implementace tohoto modelu do navrženého ekosystému je znázorněna na obrázku č. 3. 


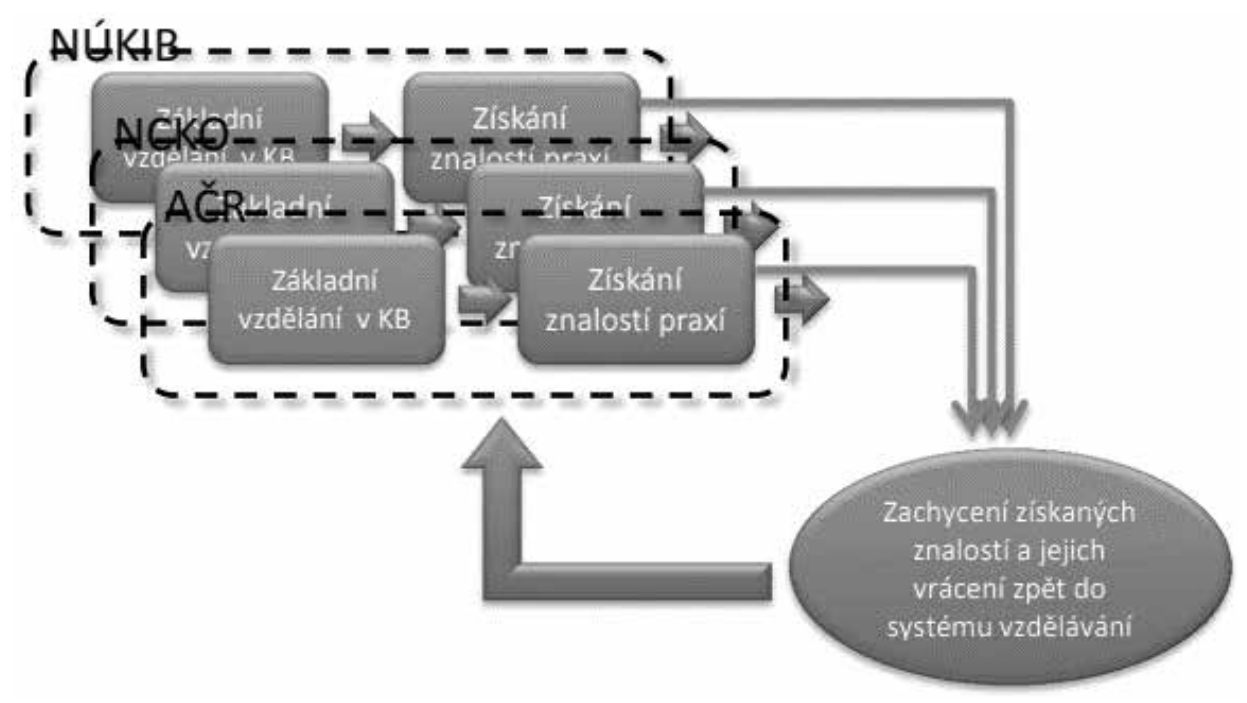

Obrázek č. 3: Zpětná vazba v ekosystému vzdělávání

\subsection{Model vztahů prvků systému vzdělávání}

Aby navrhovaný systém vzdělání mohl úspěšně fungovat, musí být navržen i model spolupráce mezi jednotlivými složkami. Model spolupráce vychází ze stanovených rolí jednotlivých složek a představuje základní prvek pro udržení navrženého ekosystému $v$ chodu. Dobře fungující spolupráce přispívá jednak k pružnému generování odborně vzdělaného personálu, který je $v$ rovnováze $s$ prírozeným odchodem, ale taktéž $\mathrm{k}$ efektivnímu vzdělávání zaměstnanců, kteří se nemusí dovzdělávat praxí, ale jsou již dopředu připraveni na pozici, kde nastupují nebo na kterou se posunují při vývoji své kariéry. Rovněž tak řízení kariér odborných zaměstnanců je pružnější a efektivnější.

Obrázek č. 4 popisuje jednotlivé aktéry a prvky systému vzdělávání odborníku kybernetické obrany a jejich vzájemné vazby. 


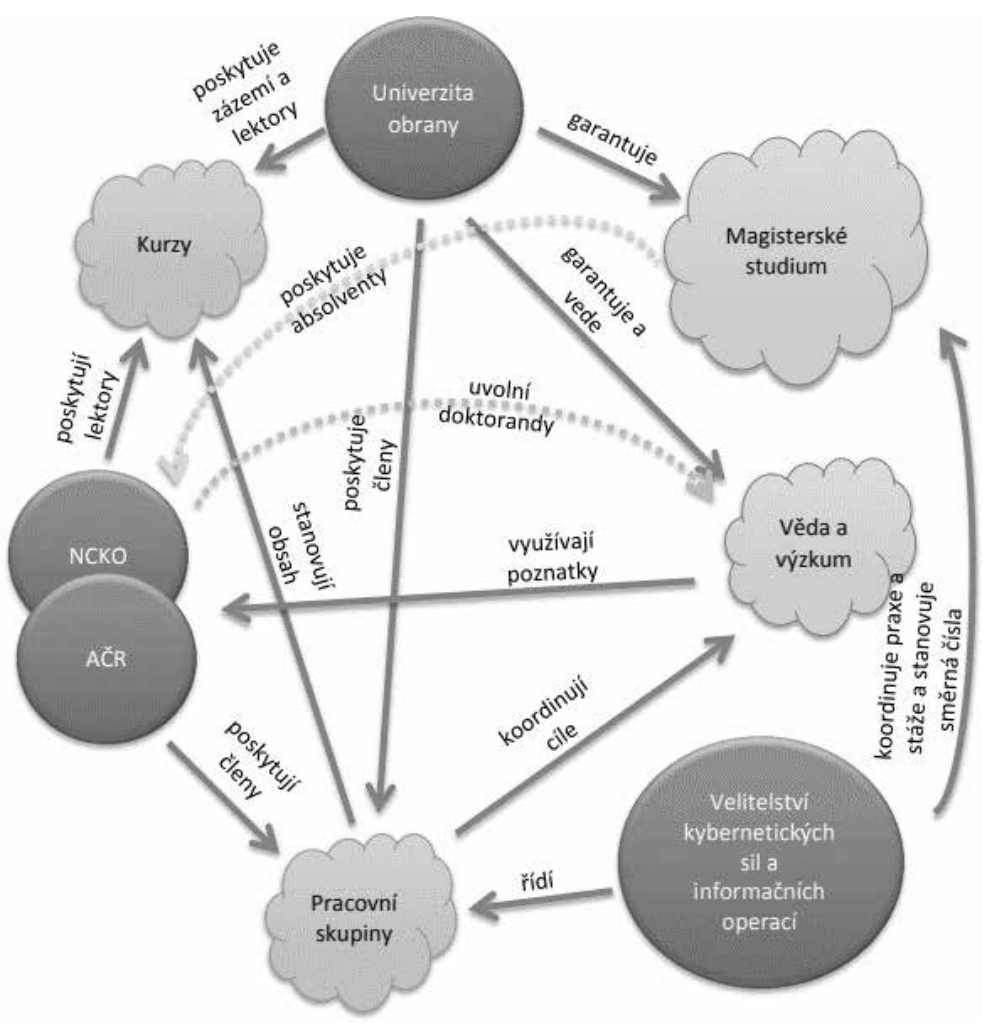

Obrázek č. 4: Model vztahů prvků systému vzdělávání

\section{ZÁVĚR}

Hlavním cíle tohoto článku bylo navrhnout systém přípravy v oblasti kybernetické bezpečnosti v podmínkách rezortu Ministerstva obrany. Stanovené otázky / okruhy problémů v kapitole 2 byly pokryty provedenou analýzou aktérů v kybernetické doméně a provedenou strategickou analýzou pro definování východisek pro navrhovaný systém vzdělávání. V neposlední řadě byl také vytvořený realizovatelný systém př́ipravy odborníku kybernetické bezpečnosti, který je postaven na konkrétních existujících, nebo právě vytvářených prvcích tohoto systému spolu s definovanými vazbami mezi těmito prvky.

Návrh systémů prípravy vychází z obecně platných principů, respektuje současnou legislativní situaci a je založen na modelu spolupráce, kdy nejsou upřednostňována krátkodobá řešení. Investice jednotlivých složek do implementace tohoto systému vzdělávání může nastartovat vzdělávací ekosystém, který po úspěšném startu pomůže zachovat a prohlubovat míru znalostí a pružně generovat vzdělané odborníky dle potřeby jednotlivých složek. Významným způsobem umožní zkrátit dobu zaškolování jednotlivých pracovníků na systemizované místo a zabrání nenávratnému odlivu znalostí mimo systém. 


\section{PŘíLOHA}

Členění témat kybernetické bezpečnosti a jejich profilace v navrženém vertikálním členění systému vzdělávání spolu $s$ identifikací témat, která mohou být obsahem karierových kurzů KVD a KGŠ.

Tato tabulka je souhrnnou informací výsledků panelu expertů účastníků KGŠ.

\begin{tabular}{|c|c|c|c|c|c|c|c|}
\hline Tématický blok & Téma & Základní & $\begin{array}{l}\text { Úroveň } \\
1\end{array}$ & $\begin{array}{l}\text { Úroveň } \\
2\end{array}$ & $\begin{array}{l}\text { Úroveň } \\
3\end{array}$ & KVD & KGŠ \\
\hline \multicolumn{8}{|l|}{$\begin{array}{l}1 \text { TECHNICKÉ/ } \\
\text { PRAKTICKÉ }\end{array}$} \\
\hline \multirow[t]{3}{*}{$\begin{array}{l}1.1 \text { FORENZNÍ } \\
\text { ANALÝZA }\end{array}$} & $\begin{array}{l}\text { Nakládání s daty a HW způsobem, který je „forensically } \\
\text { sound", tzn. způsobem v souladu s právem (vyfotit, } \\
\text { nerozbít, logovat, atd.). }\end{array}$ & & $x$ & & & & \\
\hline & $\begin{array}{l}\text { Získání dat pro analýzu (např. obraz paměti, obraz } \\
\text { disku). Analýza disku, činností uživatele (historie } \\
\text { prohlížečŭ, manipulace s USB zařízeními, instalované } \\
\text { a spouštěné aplikace a dokumenty, atd.), systémových } \\
\text { logů, sítová komunikace (potkává se s analýzou sítového } \\
\text { provozu). }\end{array}$ & $x$ & & & & & \\
\hline & $\begin{array}{l}\text { Analýza paměti (spouštěné procesy, jejich chování - } \\
\text { potkává se s analýzou malware). Přehled používaných } \\
\text { nástrojů. }\end{array}$ & $x$ & & & & & \\
\hline \multirow[t]{3}{*}{$\begin{array}{l}\text { 1.2 ANALÝZA } \\
\text { MALWARE }\end{array}$} & $\begin{array}{l}\text { Základní informace o malware jako nejběžnější způsoby } \\
\text { zajištění persistence, typický modus operandi běžných } \\
\text { malware kampaní apod }\end{array}$ & & $x$ & & & $x$ & \\
\hline & $\begin{array}{l}\text { Znalost základních metod analýzy malware (analýza } \\
\text { skriptů ve webových stránkách, dokumentů, dynamická } \\
\text { a základní statická analýza PE a ELF) a nástrojů dostup- } \\
\text { ných pro tento účel }\end{array}$ & & $x$ & & & & \\
\hline & $\begin{array}{l}\text { Možné pokračování je pokročilá analýza a reverzní } \\
\text { inženýrství. }\end{array}$ & & $x$ & & & & \\
\hline \multirow[t]{2}{*}{$1.4 \mathrm{ICS} / \mathrm{SCADA}$} & $\begin{array}{l}\text { Seznámení se světem průmyslových systémů. Odlišnosti } \\
\text { od prostředí běžných počítačŭ. }\end{array}$ & & & & $x$ & & \\
\hline & $\begin{array}{l}\text { Základy elektrotechniky. Úvod do problematiky } \\
\text { senzorových sítí, inteligentních sítí (,smart grid“), loT, } \\
\text { zabezpečovacích systémů, automatizační techniky. } \\
\text { Programování průmyslových systémů. }\end{array}$ & $x$ & & & & & \\
\hline \multirow[t]{2}{*}{$\begin{array}{l}1.5 \text { OSINT } \\
+ \text { THREAT } \\
\text { INTELLIGENCE }\end{array}$} & $\begin{array}{l}\text { Získávání dat z otevřených zdrojů, analýza a získávání } \\
\text { nových poznatků z těchto dat. }\end{array}$ & & $x$ & & & $x$ & \\
\hline & $\begin{array}{l}\text { Využití dostupných dat při řešení incidentu (mapování } \\
\text { neobjevených částí infrastruktury útočníka např. pomocí } \\
\text { WHOIS, společného hostingu, způsobu generování } \\
\text { doménových jmen). }\end{array}$ & & & $x$ & & & \\
\hline \multirow[t]{2}{*}{$\begin{array}{l}1.6 \text { INCIDENT } \\
\text { HANDLING }\end{array}$} & $\begin{array}{l}\text { Problematika zpracování incidentů jako základní } \\
\text { služba CERT týmu. Proces řešení incidentu, klasifikace } \\
\text { incidentů, metodika zpracování, spolupráce s dalšími } \\
\text { bezpečnostními týmy. }\end{array}$ & & & $x$ & & & $x$ \\
\hline & $\begin{array}{l}\text { Problematika předávání dat, jejich ochrana (např. TLP } \\
\text { protokol) }\end{array}$ & & & $x$ & & & \\
\hline
\end{tabular}




\begin{tabular}{|c|c|c|c|c|}
\hline & $\begin{array}{l}\text { Podpůrné nástroje pro zpracování incidentů a komuni- } \\
\text { kaci (tiketovací systémy, PGP, X.509), automatizované } \\
\text { zpracování strojově generovaných informací (pro } \\
\text { identifikaci incidentů) }\end{array}$ & & $x$ & \\
\hline \multirow[t]{2}{*}{$\begin{array}{l}\text { 1.7 SPRÁVA } \\
\text { SYSTÉMŮ - WIN- } \\
\text { DOWS, UNIX/ } \\
\text { LINUX, (OS X?) }\end{array}$} & $\begin{array}{l}\text { Pro řešení incidentů je nutná znalost běžných operač- } \\
\text { ních systémů a toho, jak fungují. Je nutné vědět co, } \\
\text { jakým způsobem a kam systém loguje (platí i pro běžně } \\
\text { používané aplikace). }\end{array}$ & $x$ & & \\
\hline & $\begin{array}{l}\text { Pro identifikaci a analýzu malware je nutné umět odlišit } \\
\text { anomální chování systému (např. nestandardní procesy, } \\
\text { umístění souborů, správa služeb a modulů, linkování } \\
\text { knihoven) }\end{array}$ & $x$ & & \\
\hline \multirow[t]{2}{*}{$\begin{array}{l}1.8 \text { MONITORING } \\
\text { A ANALÝZA SÍŤO- } \\
\text { VÉHO PROVOZU }\end{array}$} & $\begin{array}{l}\text { Zdroje dat pro analýzu - zachytávání paketů, toků, } \\
\text { honeypoty, systémy IDS a IPS, atd. }\end{array}$ & $x$ & & \\
\hline & $\begin{array}{l}\text { Nástroje a způsoby sběru, agregace a vizualizace } \\
\text { dat. Problematika firewallů (paketové filtry, stavové, } \\
\text { aplikační FW) a dalších sítových prvků. Metody analýzy } \\
\text { dat. Zaměření nejen na L7 v ISO/OSI modelu, ale i L2, } \\
\text { L3 a L4. }\end{array}$ & $x$ & & \\
\hline \multirow[t]{4}{*}{$\begin{array}{l}\text { 1.9 PRÁVO PRO } \\
\text { CERT }\end{array}$} & $\begin{array}{l}\text { Zákon o kybernetické bezpečnosti, související vyhlášky } \\
\text { a další relevantní zákony, vyhlášky, nařizení apod. Zákla- } \\
\text { dy mezinárodního práva pro potřeby CERT. }\end{array}$ & $x$ & & \\
\hline & $\begin{array}{l}\text { Nakládání s osobními údaji, které mohou být přítomné } \\
\text { v datech }\end{array}$ & & & $x$ \\
\hline & $\begin{array}{l}\text { Základní povědomí o práci PČR v oblasti kybernetické } \\
\text { kriminality a o mechanismu trestního řízení }\end{array}$ & $x$ & & $x$ \\
\hline & $\begin{array}{l}\text { Nakládání a práce s daty tak, aby později mohla být } \\
\text { využita jako důkazní materiál. Legal Issues }\end{array}$ & & $x$ & $x$ \\
\hline \multirow[t]{2}{*}{1.10 SOFT SKILLS } & $\begin{array}{l}\text { Netechnické dovednosti, které jsou ale důležité pro } \\
\text { úspěšné působení v CERT týmu }\end{array}$ & $x$ & & \\
\hline & $\begin{array}{l}\text { Prezentační a vyjadřovací schopnosti - kontakt s consti- } \\
\text { tuency a reprezentace týmu na konferencích. Jazykové } \\
\text { dovednosti - angličtina a čeština a schopnost psát } \\
\text { smysluplné texty gramaticky správně }\end{array}$ & $x$ & & \\
\hline $\begin{array}{l}\text { 1.11 ZÁKLADNÍ } \\
\text { INFO }\end{array}$ & $\begin{array}{l}\text { Co je to CERT, jak funguje. Spolupráce, TI, TF-CSIRT, } \\
\text { FIRST, CSIRT Network. RFC } 2350\end{array}$ & $x$ & & \\
\hline 1.12 DALŠí & $\begin{array}{l}\text { Programování, skriptování, databáze, kryptografie } \\
\text { a další předměty (např. většina z BIT na FI MU) by měly } \\
\text { sloužit jako základy pro tyhle }\end{array}$ & $x$ & & \\
\hline \multicolumn{5}{|l|}{$\begin{array}{l}2 \text { NETECHNICKÉ / } \\
\text { MANAŽERSKÉ }\end{array}$} \\
\hline \multirow[t]{5}{*}{$\begin{array}{l}\text { 2.1 ZÁKLADNÍ DI- } \\
\text { GITÁLNÍ HYGIENA }\end{array}$} & $\begin{array}{l}\text { Základní bezpečnostní doporučení, bezpečné používání } \\
\text { ICT technologií }\end{array}$ & $x$ & & $x$ \\
\hline & $\begin{array}{l}\text { Fyzická bezpečnost, bezpečnost hardware, bezpečnost } \\
\text { software, zálohování dat, služby (e-mail, internetové } \\
\text { bankovnictví.) }\end{array}$ & $x$ & & $x$ \\
\hline & Soukromé vs pracovní využívání ICT & $x$ & & $x$ \\
\hline & Politika hesel, autentizace & $x$ & & $x$ \\
\hline & Ochrana soukromí a sdílení osobních údajů & $x$ & & $x$ \\
\hline
\end{tabular}




\begin{tabular}{|c|c|c|c|c|c|c|c|}
\hline & Využívání sociálních sítí, bezpečné prohlížení webu & $x$ & & & & $\mathrm{x}$ & \\
\hline & Bezpečná komunikace vs veřejná wifi, šifrování & $\mathrm{x}$ & & & & $\mathrm{X}$ & \\
\hline & Sociální inženýrství & $x$ & & & & $x$ & \\
\hline & Kyberšikana, kyberstalking, kybergrooming & & & & $x$ & & \\
\hline & $\begin{array}{l}\text { Přehled nejčastějších hrozeb/útoků na uživatele - } \\
\text { phishing, malware/ransomware }\end{array}$ & $\mathrm{x}$ & & & & $\mathrm{X}$ & \\
\hline \multirow{5}{*}{$\begin{array}{l}\text { 2.2 NÁRODNÍ } \\
\text { STRATEGIE } \\
\text { A POLITIKY } \\
\end{array}$} & $\begin{array}{l}\text { Odborná terminologie - počínaje definicí } \\
\text { kyberprostoru atd. }\end{array}$ & $x$ & & & & & \\
\hline & $\begin{array}{l}\text { Koncept zajištování KB v ČR - kybernetická bezpečnost } \\
\text { versus kybernetická obrana versus kybernetická krimi- } \\
\text { nalita, role státu }\end{array}$ & $x$ & & & & & $x$ \\
\hline & $\begin{array}{l}\text { Kybernetická bezpečnostní politika, význam KB ve } \\
\text { vztahu ke státu, strategicko-právní rámec }\end{array}$ & $\mathrm{x}$ & & & & & $x$ \\
\hline & $\begin{array}{l}\text { Představení relevantních subjektů (NCKB/govcert.cz), } \\
\text { zpravodajské služby (NCKS), PČR, Národní CERT a další }\end{array}$ & $\mathrm{x}$ & & & & $\mathrm{X}$ & \\
\hline & Role CSIRT/CERT týmů & & $\mathrm{X}$ & & & & \\
\hline \multirow{6}{*}{$\begin{array}{l}\text { 2.3 PRÁVO } \\
\text { A MEZINÁRODNÍ } \\
\text { ORGANIZACE }\end{array}$} & Zákon o kybernetické bezpečnosti & $x$ & & & & & \\
\hline & Kontrola a audit & & & $x$ & & & \\
\hline & $\begin{array}{l}\text { Krizový zákon, vyhláška 315/2014 a 316/2014, další } \\
\text { legislativní normy ČR }\end{array}$ & & $\mathrm{X}$ & & & & $x$ \\
\hline & $\begin{array}{l}\text { Mezinárodní spolupráce při zajišt́ování KB - bilaterální, } \\
\text { multilaterální (NATO, EU, OBSE, OSN) }\end{array}$ & & & $\mathrm{x}$ & & & $x$ \\
\hline & $\begin{array}{l}\text { Právo a kyberprostor, mezinárodní právo, problém } \\
\text { atribuce }\end{array}$ & & & & & & $x$ \\
\hline & Regulace v kyberprostoru, směrnice NIS & & & & $x$ & & \\
\hline \multirow{5}{*}{$\begin{array}{l}2.4 \text { KON- } \\
\text { TEXTUÁLNÍ } \\
\text { A ANALYTICKÉ } \\
\text { SCHOPNOSTI }\end{array}$} & Historické aspekty KB, geneze kybernetických hrozeb & & $\mathrm{X}$ & & & $\mathrm{X}$ & \\
\hline & Taxonomie útoků & $x$ & & & & & \\
\hline & $\begin{array}{l}\text { Kyberkriminalita, kybernetický terorismus, kybernetická } \\
\text { špionáž, kybernetický konflikt/válka }\end{array}$ & & & & & $\mathrm{X}$ & \\
\hline & Základní typologie a motivace útočníků & & & & & $x$ & \\
\hline & $\begin{array}{l}\text { Znalost a používání základních OSINT nástrojů - vyhle- } \\
\text { dávání z otevřených zdrojů }\end{array}$ & & & & & $X$ & \\
\hline $\begin{array}{l}2.5 \text { VZDĚLÁVÁ- } \\
\text { NÍ A CVIČENÍ } \\
\text { KYBERNETICKÉ } \\
\text { BEZPEČNOSTI }\end{array}$ & $\begin{array}{l}\text { Typologie cvičení - technické/table-top/komunikační, } \\
\text { národní/mezinárodní }\end{array}$ & & $x$ & & & $x$ & \\
\hline
\end{tabular}




\begin{tabular}{|c|c|c|c|c|c|c|c|}
\hline & Organizace a plánování cvičení & & & & $x$ & $x$ & \\
\hline & $\begin{array}{l}\text { Tvorba scénářů cvičení, reflexe aktuálních trendů a je- } \\
\text { jich překlopení do scénářů }\end{array}$ & & & & $x$ & & $x$ \\
\hline & $\begin{array}{l}\text { Způsob/formy vzdělávání a prevence v oblasti kyberne- } \\
\text { tické bezpečnosti dle definovaných cílových skupin }\end{array}$ & & $x$ & & & & $x$ \\
\hline \multirow{6}{*}{$\begin{array}{l}2.6 \text { KRITICKÁ } \\
\text { INFORMAČNÍ } \\
\text { INFRASTRUK- } \\
\text { TURA }\end{array}$} & $\begin{array}{l}\text { Informační a komunikační systémy, významné informač- } \\
\text { ní systémy }\end{array}$ & $x$ & & & & & \\
\hline & Struktura klíčových informačních/komunikačních služeb & $x$ & & & & & \\
\hline & Bezpečnostní politiky & $x$ & & & & & \\
\hline & Systémy řízení bezpečnosti informací & $x$ & & & & $x$ & \\
\hline & Řízení kontinuity činností & & & & $x$ & & \\
\hline & Analýza rizik & & & & $\mathbf{x}$ & & \\
\hline \multirow[t]{3}{*}{ 2.7 OSTATNÍ } & Manažerské dovednosti & & & & $x$ & $x$ & \\
\hline & Motivace a vedení lidí & & & $x$ & & & $x$ \\
\hline & Projektové řízení & & & $x$ & & & $x$ \\
\hline \multirow[t]{10}{*}{$\begin{array}{l}3 \text { SPECIFICKÉ / } \\
\text { OFENZIVNÍ }\end{array}$} & $\begin{array}{l}\text { Real-time schopnosti zajištovat (aktivní) kybernetickou } \\
\text { obranu }\end{array}$ & & $x$ & & & & \\
\hline & $\begin{array}{l}\text { Aktivní identifikace a rekognoskace nepřítele } \\
\text { v kyberprostoru }\end{array}$ & & $x$ & & & $x$ & \\
\hline & $\begin{array}{l}\text { Schopnost provádět odvetné útoky (hacking/ } \\
\text { striking-back) }\end{array}$ & & & & $x$ & & \\
\hline & Sběr informací o zájmových aktérech & & & $x$ & & & \\
\hline & $\begin{array}{l}\text { Data mining a analýza dat ze sociálních sítí, analýza } \\
\text { obsahu }\end{array}$ & & & $x$ & & & \\
\hline & Analýza malware, reverzní inženýrství & & & & $x$ & & \\
\hline & $\begin{array}{l}\text { Znalost jednotlivých fází kybernetických útoků (re- } \\
\text { connaissance, scanning, gaining access, maintaining } \\
\text { access, covering tracks...) }\end{array}$ & & $x$ & & & $x$ & \\
\hline & $\begin{array}{l}\text { Schopnosti identifikace útoku, včetně Advanced Persis- } \\
\text { tent Threat (APT) a následná analýza }\end{array}$ & & $x$ & & & & \\
\hline & $\begin{array}{l}\text { Zvládnutí základních technik kybernetické bezpečnosti, } \\
\text { blokace a izolace útočníka }\end{array}$ & & $x$ & & & & \\
\hline & $\begin{array}{l}\text { Účinné zabezpečení vlastních sítí, systémů a informací } \\
\text { (tj. neustálé hledání zranitelností ve svých sítích a } \\
\text { systémech - pen testing, detekce anomálií v sítích, data } \\
\text { analysis, šifrovací nástroje + provádění cvičení, kontin- } \\
\text { genční plány, apod.) }\end{array}$ & & $x$ & & & & \\
\hline
\end{tabular}




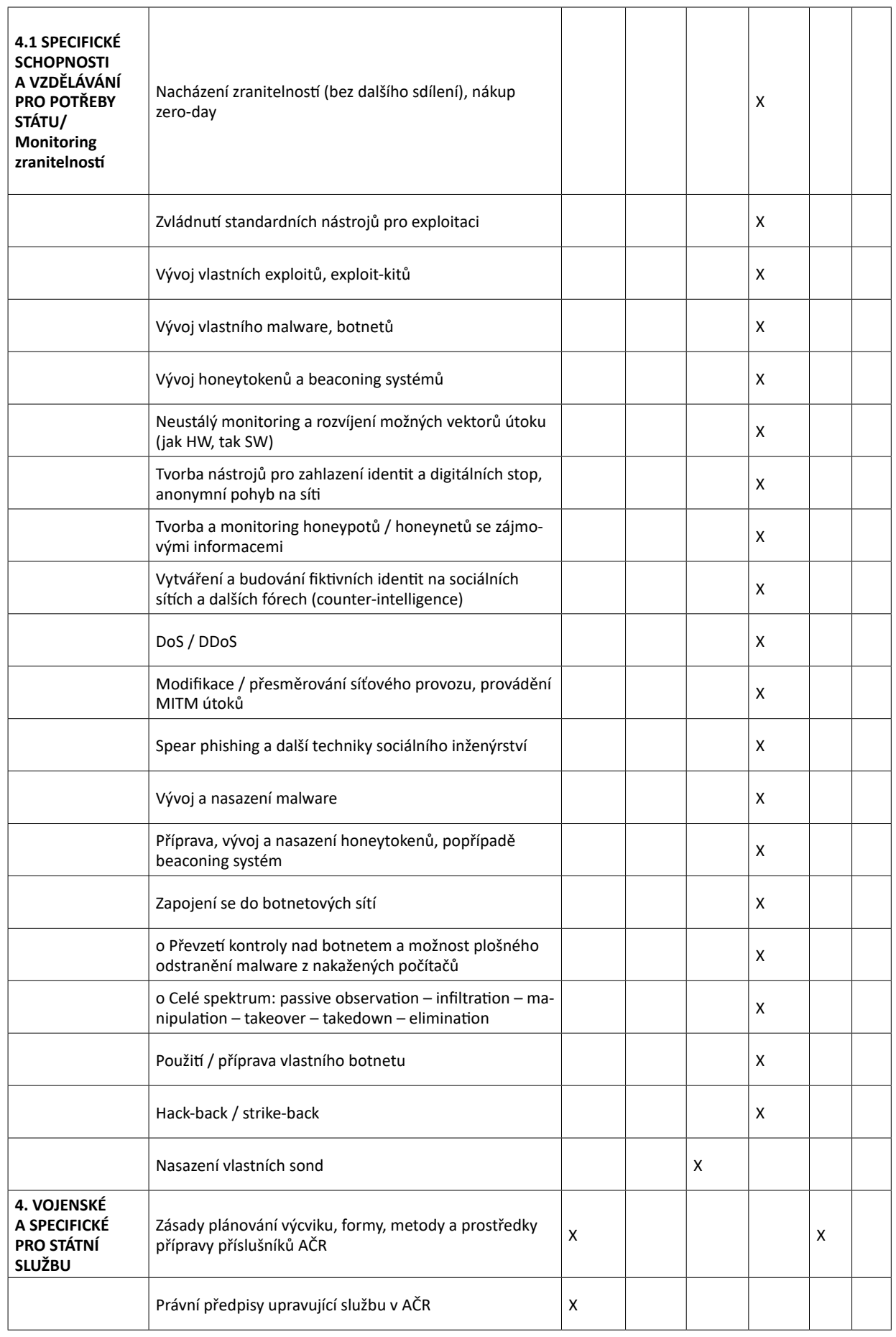




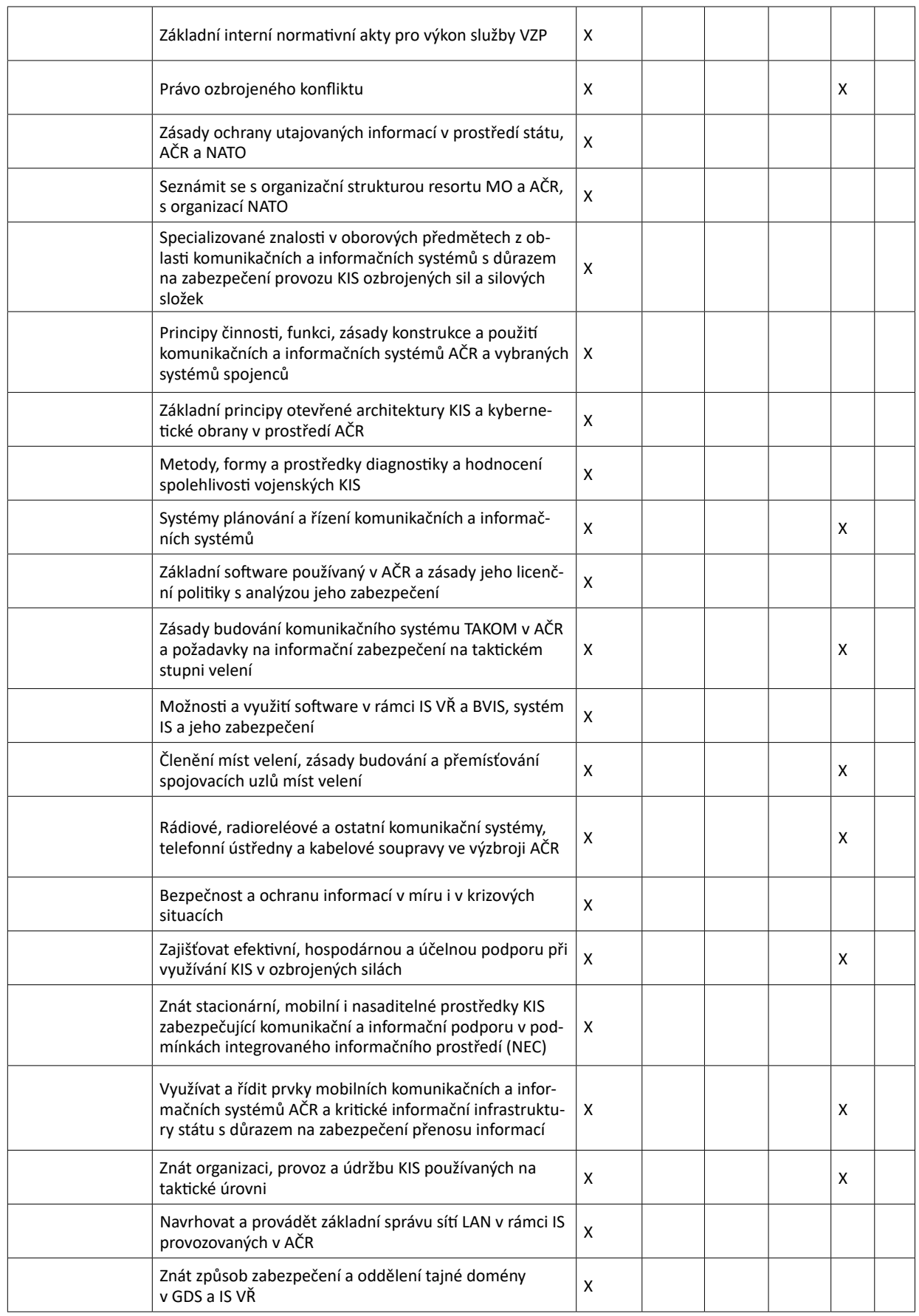




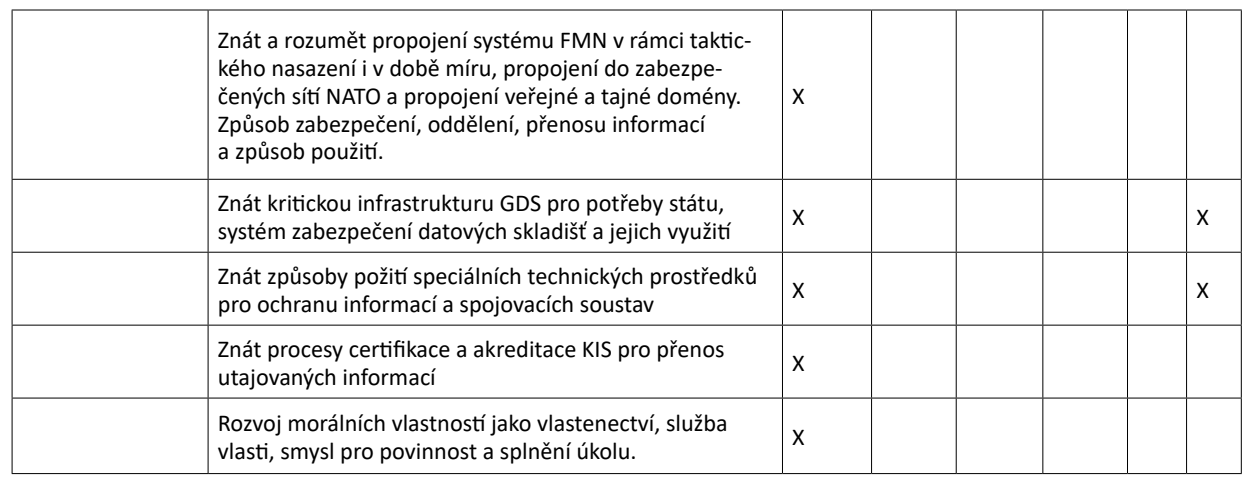

Authors: Pplk. gšt. doc. Ing. Petr Františ, Ph.D., narozen v roce 1976. Je absolventem Vojenské akademie v Brně (2001), kde dále absolvoval doktorské studium (2004). Od roku 2003 působí jako odborný asistent na Vojenské akademii a později Univerzitě obrany. $V$ současné době zastává funkci zástupce vedoucího Katedry informatiky, kybernetické bezpečnosti a robotiky. Zabývá se problematikou modelování a simulace, architektury výpočetních systémů a kybernetické bezpečnosti.

Plk. gšt. doc. Ing. Jan Hodický, Ph.D., narozen v roce 1977. Je absolventem Vojenské akademie v Brně. V roce 2004 získal doktorát v oblasti Informatiky a výpočetní techniky na Univerzitě obrany v Brně. Do roku 2012 působil jako odborný asistent na katedře Komunikačnich a informačních systémů. Poté nastoupil na pozici vedoucího odboru Doktrín, vzdělávání a výcviku na Centru excelence modelování a simulace v Římě. Od roku 2017 do roku 2018 pracoval jako vedoucí vědecký pracovník na Centru bezpečnostních a vojenskostrategických studii na Univerzitě obrany v Brně. V roce 2019 se stal vedoucím Katedry letecké techniky na UO v Brně. Zabývá se problematikou aplikování modelování a simulace do vojenství.

How to cite:FRANTIŠ, Petr and Jan HODICKÝ. Analýza a model systému prípravy odborníků kybernetické obrany. Vojenské rozhledy. 2019, 28 (3), 097-116. ISSN 1210-3292 (print), 2336-2995 (on-line). Available at: www.vojenskerozhledy.cz 
Informace

\section{Př́prava občanů k obraně státu}

\section{Preparing citizens to defend the state}

\section{Miroslav Jurenka}

Abstrakt: Článek pojednává o přistupech a úkolech vzdělávání v oblasti bezpečnosti a obrany České republiky. Vychází z právního rámce a zároveň seznamuje odbornou veřejnost s iniciativou a postupem Ministerstva obrany a Ministerstva školství, mládeže a tělovýchovy České republiky v předmětné oblasti.

Koncepce Přípravy občanů k obraně státu, která byla schválena Usnesením vlády České republiky ze dne 1 . dubna 2019, reaguje na výsledky v implementaci Koncepce přijaté v roce 2013 a ukazuje na neuspokojivou situaci v její realizaci. Pojednává o nových přístupech a úkolech vzdělávání v oblasti bezpečnosti a obrany státu.

Abstract: The article deals with approaches and tasks of education in the field of security and state defence of the Czech Republic. It is based on the legal framework and informs the professional public about the initiative and process of the Ministry of Defence of the Czech Republic and Ministry of Education, Youth and Sports of the Czech Republic in particular area. Preparation of citizens for state defence conception, which was approved by the resolution of the Government of the Czech Republic on the $1^{\text {st }}$ April 2019, reacts to results within the implementation of this Conception adopted in 2013 and reflects an unsatisfactory situation in its realization. It deals with new approaches and tasks of education in the field of security and state defence.

Klíčová slova: Implementace; koncepce; Ministerstvo obrany; obrana státu; obyvatelstvo; Vzdělávání.

Key words: Implementation; Conception; Ministry of Defence; State Defence; Population; Education. 


\section{ÚVOD}

Od počátku své existence musí lidstvo zápasit nejen o záchranu hmotných a kulturních hodnot, ale především o uchování samotného života. Vědeckotechnický pokrok přinesl lidské společnosti vedle řady příznivých stránek i zvýšení rizika vzniku mimořádných událostí a krizových situací. Lidské poznání dokáže již poměrně dokonale objasnit zdroje a zákonitosti průběhu působení přírodních a společenských jevů vyvolávajících tyto situace, ale nedokáže vzniku dané situace plně zabránit. S vývojem společnosti dochází i k proměnám bezpečnostního prostředí a jsou nalézány nové formy a metody k zajištění základních hodnot člověka. V uplynulých dvaceti letech došlo ke snížení celkového napětí a poklesu rizika celosvětové konfrontace. Geopolitické postavení České republiky (ČR) se $v$ důsledku řady demokratizačních a integračních změn v euroatlantickém prostoru zásadně změnilo. ČR je členem organizace Severoatlantické smlouvy (NATO) a Evropské unie (EU) a stala se zemí, které přímo sousedí s členskými státy těchto organizací. Tím byla významně posílena její bezpečnost.

Přesto však globalizovaný, vzájemně úzce propojený svět, v němž prostorové vzdálenosti ztrácejí na relevanci, konfrontuje ČR s novými bezpečnostními hrozbami. Reflexe proměn globálního bezpečnostního prostředí i bezpečnostního prostředí ČR poukazuje na skutečnost, že fungování státu může být ohroženo nebo narušeno s různou intenzitou a různým způsobem. Problematika bezpečnosti patří k nejčastěji skloňovaným termínům v diskusi o současných mezinárodních vztazích.

Bezpečnost státu je stále více vymezena schopností čelit hrozbám společenského i přírodního charakteru, přičemž jejich hranice není jednoznačně vymezena, hrozby se vzájemně prolínají a přerůstají jedna v druhou. Rozličný charakter hrozeb a míra jejich rizika klade nové nároky na efektivní a fungující bezpečnostní systém.

Ochrana životů, zdraví a majetkových hodnot je spolu se zajištěním svrchovanosti, územní celistvosti a ochranou demokratických základů České republiky základní povinností a tedy i funkcí státu. PInění tohoto úkolu vyžaduje nejen analýzu zahraničně-politických a vojenských faktorů vnější bezpečnosti, ale také objektivní posouzení široké škály vnitro-politických, ekonomických, sociálních, etnických, náboženských a jiných aspektů ovlivňujících bezpečnost. Př́prava občanů k obraně státu (POKOS) je jedním z nástrojů obranné politiky a nedílnou součástí plánování obrany státu. V České republice je ze zákona tato oblast předmětem vzdělávání a výuky ve školách.

Zákonná povinnost občanů bránit svou vlast nezanikla ani s profesionalizací Armády České republiky. Systematická diferencovaná příprava občanů k obraně státu je jedním z předpokladů vytvoření potřebných schopností k zajištování obrany jednotlivců i celé společnosti.

\section{PRÁVNÍ RÁMEC PRO PŘíPRAVU OBČANU゚ K OBRANĚ STÁTU}

Základním právním východiskem pro danou problematiku je Zákon č. 222/1999 Sb., o zajištóvání obrany České republiky, který ř́ká, že v § 52: 
- prríprava občanů k obraně státu je dobrovolná,

- za stavu ohrožení státu nebo válečného stavu je př́prava občanů $\mathrm{k}$ obraně státu povinná,

- príprava občanů k obraně státu zahrnuje zejména zdravotnickou př́pravu, prípravu k civilní obraně, zájmovou činnost s technickým a sportovním zaměřením, přípravu obyvatelstva k sebeobraně a vzájemné pomoci a další činnosti spojené s branností a se zabezpečením prípravy $k$ obraně státu,

- př́prava občanů $k$ obraně státu má charakter vzdělávání a provádí se $v$ rámci základního a středního vzdělávání i v rámci jiné státem uznané vzdělávací činnosti. Občany k obraně státu připravují zejména školy, školská zařízení a další vzdělávací zařízení,

- na přípravě občanů k obraně státu se mohou podílet i občanská sdružení, církve, náboženské společnosti a další právnické osoby podle svého účelu a poslání v součinnosti s územními samosprávnými celky,

- za prípravu občanů k obraně státu podle tohoto zákona a podle zvláštních právních předpisů odpovídají ministerstva, správní úrady a územní samosprávné celky. Ministerstvo spolupracuje s Ministerstvem školství, mládeže a tělovýchovy na zabezpečení odborné složky obsahu vzdělávání ve vydávaných učebních dokumentech v oblasti prípravy občanů k obraně státu.

Vláda k zajištování obrany státu v míru:

a) vyhodnocuje rizika ohrožení státu, která mohou být přičinou ozbrojeného konfliktu a činí nezbytná opatření ke snížení, popřípadě vyloučení těchto rizik,

b) schvaluje strategickou koncepci obrany státu,

c) rídí plánování obrany státu, stanoví obsahovou náplň jednotlivých plánů obrany státu a časové etapy pro jejich zpracování,

d) rozhoduje o základních opatřeních přípravy státu k obraně a jejím organizování,

e) rozhoduje o základních směrech výstavby, přípravy a použití ozbrojených sil a o zajištění obrany státu,

f) schvaluje koncepci mobilizace ozbrojených sil,

g) rozhoduje o prověrení opatření pro zabezpečení obrany státu podle § 41 odst. 2,

h) schvaluje koncepci př́ipravy občanů k obraně státu,

i) stanoví k provedení svých rozhodnutí při zajištování obrany státu úkoly ministrům, vedoucím jiných správních úřadů a obcím při výkonu jejich přenesené působnosti,

j) rozhoduje o dalších nepředvídatelných úkolech nezbytných k zajištování obrany státu.

Zákon č. 222/1999 Sb., ukládá vládě mimo jiné schvalování „Koncepce př́pravy občanů k obraně státu, " kterou zpracovává Ministerstvo obrany v úzké součinnosti s Ministerstvem školství, mládeže a tělovýchovy. 


\section{SITUACE VE SPOLEČNOSTI}

Příprava občanů k obraně státu je nedílnou součástí plánování obrany státu. Úroveň připravenosti občanů $v$ této oblasti významně ovlivňuje funkčnost systému zajištování obrany České republiky jako celku. Kvalita, pravidelnost a komplexní zaměěení prípravy občanů k obraně státu přispívají ke snižování škod na majetku a zejména ke snižování ztrát na lidských životech při vyhlášení stavu ohrožení státu1 nebo válečného stavu, ale i při běžných mimořádných událostech či za krizových situací nevojenského charakteru.

V systému zajištování obrany je role občana jedinečná-je zároveň subjektem i objektem zajištováníobrany.Je protovzájmuobčana, aleivzájmustátuajehoinstitucípřípravuobčanů k obraně řešit systematicky a koncepčně, přičemž základním stavebním kamenem tohoto systému musí být vzdělávání na základních a středních školách. Vzhledem k existenci plně profesionální Armády České republiky je tato potřeba navíc umocněna z důvodu postupného mizení vazeb mezi občany státu a příslušníky jeho ozbrojených sil.

\subsection{Analýza stavu}

Přijetí první Koncepce předcházela v roce 2011 hluboká analýza dané oblasti ve státní správě, samosprávě $s$ důrazem na školství. $V$ provádění prípravy občanů $k$ obraně státu ve smyslu zákona č. 222/1999 Sb. o zajištování obrany České republiky byly identifikovány následující problémy a jejich př́činy: ${ }^{1}$

- liberální pojetí povinností občanů k obraně státu, zakotvené v príslušných právních předpisech,

- nejsou nastaveny systémové a organizační vazby, které by umožnily prípravu (výchovu a vzdělávání) občanů $k$ obraně v žádoucím rozsahu a s potřebným obsahem realizovat,

- nejsou stanoveny konkrétní působnosti na príslušných ministerstvech a dalších ústředních správních úradech,

- právní úprava sice zmiňuje realizaci prípravy občanů k obraně, ta však není rozvedena dalšími právními předpisy, ani jiným způsobem rozpracována,

- nejsou dostatečně alokovány a využívány finanční prostředky pro přípravu občanů k obraně,- -

- neexistují účinné mechanismy a normativní postupy, které by podporovaly vzájemnou mezirezortní spolupráci při řešení přípravy občanů k obraně,

- problematika prípravy občanů k obraně není v potřebném rozsahu zahrnuta do osnov základních a středních škol a je zaměňována za ochranu obyvatelstva v př́padě krizových situací a mimořádných událostí nevojenského charakteru,

- role Univerzity obrany v Brně jakožto státní vysoké školy a možného významného nástroje realizace vzdělávání včetně zajištóvání certifikací v rámci zvláštní odborné

1 Koncepce prípravy občanů k obraně státu. Praha: MO, 2012. 
zpưsobilosti úredníků státní správy a územních samospráv v oblasti obrany státu je nedostatečná a není právně vymezena,

- v Plánu obrany není rozpracován systém přípravy občanů k obraně státu v období zhoršování bezpečnostní situace $v$ důsledku ohrožení vojenského charakteru a za stavu ohrožení státu,

- neexistuje koordinovaný přístup a podíl rezortu MO při zařazování problematiky obrany státu do studijních programů vysokých škol, proto príprava nemá jednotný obsah a její úroveň je závislá na připravenosti konkrétních lektorů a učitelů,

Postupně se objevují určité tendence, kdy část odborné i laické veřejnosti si uvědomuje možné dopady nedostatkủ systému př́pravy občanů k obraně na společnost a její bezpečnost. Důkazem politického zájmu je zařazení této problematiky do nejnovějších strategických dokumentů, Bezpečnostní strategie ČR a Obranné strategie ČR.

Je zřejmé, že klíčovým prvkem obranného systému musí být dokonale připravený odborník v oblasti zajištování obrany státu, úředník státní správy a územní samosprávy. Povědomí o povinnostech občana $k$ obraně státu včetně branné povinnosti je nutné se zaměřit v mírovém stavu na kategorie žáků základních a středních škol a studentů vyšších odborných škol a na budoucí a stávající učitele.

Za největší problémy v systému vzdělávání pro přípravu občanů k obraně státu lze považovat absenci odpovědnosti a povinnosti dotčených orgánů danou zákony, neexistenci uceleného systému prípravy na celostátní úrovni, neexistenci uceleného zdroje informací a nezájem většiny občanů o př́pravu. To má za následek nesystematickou a nekoordinovanou činnost ve vzdělávání v předmětné oblasti.

\subsection{Identifikace problému a opatření}

Na základě analýzy stavu plnění Zákona č. 222/1999 Sb., o zajištování obrany České republiky bylo vládou rozhodnuto o zpracování koncepce. Byla zřízena meziresortní a resortní pracovní skupina, kde řídící a koordinující funkci měla Sekce obranné politiky strategie Ministerstva obrany. Koncepce prípravy občanů k obraně státu byla schválena Usnesením vlády České republiky č. 38 ze dne 16. ledna 2013.

Nastalo pětileté období implementace Koncepce do praxe. Hlavním úkolem implementace Koncepce bylo posílit roli MO i ostatních zainteresovaných rezortů při zvyšování připravenosti občanů k obraně v případě krizových situací a vytvořit podmínky pro jejich aktivní zapojení a připravenost k obraně státu.

Implementace Koncepce přispěla ke zkvalitnění a posílení účasti MO na přípravě občanů $\mathrm{k}$ obraně státu a je jedním z důležitých předpokladů pro zvýšení občanského povědomí o důležitosti prípravy občanů $k$ obraně státu a zvýšení společenského uznání armády v naší demokratické společnosti.

Nejvíce práce se podařilo splnit na základních školách. Problematika prípravy občanů k obraně státu byla zahrnuta do rámcového vzdělávacího programu a do školních vzdělávacích programů základních škol. Následně by měla být zahrnuta i do vzdělávání na středních školách. Měla by tak vytvářet u žáků a studentů pozitivní hodnotový systém 
opřený o historickou zkušenost a ovlivňovat jejich postoje v oblastech obrany státu a ochrany fyzického i duševního zdraví, životů, životního prostředí a majetku při různých rizikových situacích a mimořádných událostech.

$\mathrm{Na}$ této úrovni byla př́prava občanů $\mathrm{k}$ obraně státu zaměřena zejména na zdravotnickou přípravu, prípravu k civilní ochraně a přípravu k sebeobraně a vzájemné pomoci v krizových situacích vojenského i nevojenského charakteru. Žáci a studenti v rámci vzdělávání získávají základní informace o současném bezpečnostním prostředí, o výhodách členství ČR v mezinárodních bezpečnostních a politicko-vojenských organizacích, o principech obrany státu a o úloze ozbrojených sil ČR při zajištování obrany státu a při řešení celého spektra krizových situací. Příprava občanů k obraně státu je koncipována a v rámci jednotlivých oborů vzdělání tak, aby rozvíjela občanské a právní vědomí žáků a studentů, posilovala jejich smysl pro osobní i občanskou odpovědnost, motivovala je k aktivní a kvalitní účasti na životě demokratické společnosti v souvislosti s plněním úkolů obrany státu.

Ministerstvo obrany provádí akreditované školení pro učitele základních škol v rámci dalšího vzdělávání pedagogických pracovníků. Na školení se mohou přihlásit rovněž budoucí učitelé - studenti pedagogických fakult. Školení probíhá zpravidla na krajských vojenských velitelstvích.

K doplnění a zatraktivnění výuky probíhají na vybraných základních a středních školách prezentační akce, pořádané odborem komunikace Ministerstva obrany v součinnosti s jednotlivými organizačními celky rezortu. Přestože primárním cílem těchto akcí je zábavnou a interaktivní formou představit ozbrojené síly a Armádu ČR, informovat o jejich poslání, současné činnosti, výcviku, výstroji či výzbroji, je toto úsilí rovněž chápáno jako cesta, kterou je možné žákům i pedagogům předávat i méně známé informace, ke kterým by se jinak nedostali (např. branná povinnost, činná služba apod.). Školy mají o pořádání prezentací s vazbou na POKOS mimořádný zájem.

Byla vydána „Příručka pro učitele základních škol“, která orientuje učitele v hlavních otázkách obrany státu. Pro učitele, žáky i veřejnost byly vytvořeny velmi kvalitní stánky www.pokos.army.cz.

Koncepce př́pravy občanů k obraně státu z roku 2013 předpokládala dosažení požadovaného stavu do konce roku 2018. Většina stanovených cílů byla splněna. Na další období připravilo Ministerstvo obrany spolu s ostatními dotčenými složkami novou Koncepci na léta 2019 - 2024, kterou schválila vláda ČR dne 1. 4. 2019.

\section{KONCEPCE PŘíPRAVY OBČANU゚ K OBRANĚ STÁTU NA ROKY 2019 - 2024}

Východiskem pro zpracování nové Koncepce bylo kromě platného právního řádu také vyhodnocení splnění opatření vyplývajících z předchozí koncepce, analýza současného 
stavu provádění prípravy občanů $\mathrm{k}$ obraně státu a zásady stanovené Bezpečnostní strategií České republiky² a Obrannou strategií České republiky ${ }^{3}$.

Koncepce bere do úvahy dosavadní poznatky, zjištění a zkušenosti Ministerstva obrany a MŠMT při provádění přípravy občanů k obraně státu. Při její tvorbě byly využity související koncepční materiály jiných rezortů a výsledky činnosti mezirezortních pracovních skupin, zabývajících se problematikou vzdělávání v oblasti bezpečnosti státu.

Na tvorbě Koncepce se podílely věcně příslušné správní úřady, její obsah byl diskutován také se zástupci akademické obce, s odbornou veřejností, profesními sdruženími a nestátními neziskovými organizacemi.

Při zpracování Koncepce byly zohledněny rovněž využitelné zkušenosti z provádění přípravy občanů k obraně státu v Mad’arsku, Polsku, na Slovensku a v Německu.

Při vyhodnocení Koncepce přípravy občanů k obraně státu na roky 2013-2018 bylo konstatováno, že většina cílů stanovených touto koncepcí byla splněna. $Z$ tohoto pohledu Ize za pozitivní považovat zejména tyto skutečnosti:

- problematika obrany státu byla v roce 2013 zapracována do rámcových vzdělávacích programů pro základní vzdělávání a základní školy ji od 1. zárí 2013 začaly vyučovat,

- v září 2014 byla Ministerstvu obrany ze strany Ministerstva školství, mládeže a tělovýchovy udělena akreditace k provádění vzdělávacích programů pro účely zákona č. 563/2004 Sb., o pedagogických pracovnících a o změně některých zákonů; zároveň byly akreditovány programy dalšího vzdělávání pedagogických pracovníků působících na základních a následně také na středních školách,

- v rámci novelizace zákona č. 111/1998 Sb., o vysokých školách, bylo úpravou provedenou v $\S 78$ odst. 6 zajištěno, že v případě akreditace studijních programů zaměřených na př́ípravu odborníků v oblasti bezpečnosti České republiky je podmínkou pro udělení akreditace studijního programu (respektive pro uskutečňování studijního programu na základě oprávnění vyplývajícího z institucionální akreditace) kladné stanovisko (respektive povolení) Ministerstva obrany i Ministerstva vnitra,

- byl zaveden systém provádění prezentací organizačních celků rezortu Ministerstva obrany na podporu vzdělávacího procesu na základních a středních školách11 a prezentací pro širokou veřejnost,

- na podporu procesu přípravy občanů k obraně státu byly Ministerstvem obrany vytvořeny dotační programy.

Vyhodnocením Koncepce př́pravy občanů k obraně státu na roky 2013 až 2018 a objektivní analýzou současného stavu provádění přípravy občanů k obraně státu bylo identifikováno několik zásadních nedostatků.

Za nejzávažnější z nich Ize označit fakt, že stávající pedagogický sbor, zejména na základních, ale i středních školách, není k výuce problematiky obrany státu dostatečně odborně připraven, nemá dostatek informací k obsahu výuky a nedisponuje doporučeními ze strany Ministerstva školství, mládeže a tělovýchovy k formám a metodám

2 Schválená usnesením vlády ze dne 4. února 2015 č. 79.

3 Schválená usnesením vlády ze dne 13. března 2017 č. 194. 
výuky předmětné problematiky v jednotlivých hodinách. Tato skutečnost je umocňována neefektivním systémem prípravy budoucích pedagogických pracovníků v oblasti obrany státu na pedagogických fakultách vysokých škol.

V rámci analýzy současného stavu byly dále identifikovány tyto podstatné nedostatky:4

- problematika obrany státu je sice v potřebném rozsahu zahrnuta do rámcových vzdělávacích programů pro základní vzdělávání, do výuky je však zařazována spíše okrajově, dle šetření České školní inspekce v prosinci 2015 otázky obrany státu více než okrajově vyučovala pouze polovina základních škol a třetina víceletých gymnázií,

- na základních školách nejsou dosahovány očekávané výstupy z učení - z výběrového zjištování výsledků vzdělávání v bezpečnostních tématech provedeného Českou školní inspekcí na jaře 2017 vyplývá, že průměrná úspěšnost žáků 9. ročníků základních škol v odpovědích na testové položky tematické části obrana státu dosahuje pouze $51 \%$,

- stejně jako ostatní bezpečnostní témata, i problematika obrany státu je na základních školách vyučována roztřištěně v několika předmětech, což potvrzuje i zpráva Ministerstva vnitra o výsledcích podrobné analýzy současného stavu výuky všech bezpečnostních témat ve školách,

- na některých základních školách dochází $\mathrm{k}$ tomu, že výchovu a vzdělávání $v$ oblasti obrany státu neprovádí pedagogický sbor, ale je svěřena jiným subjektům, například spolkům, nestátním neziskovým organizacím, právnickým a fyzickým osobám apod., které tak nahrazují roli škol, místo toho, aby jejich participace měla pouze zákonem stanovený doplňkový charakter,

- Národní institut pro další vzdělávání a prostřednictvím krajských vojenských velitelství také Ministerstvo obrany provádějí akreditovaná školení v rámci dalšího vzdělávání pedagogických pracovníků, účast učitelů je však nízká, školy o tuto aktivitu neprojevují zájem (např́klad do kurzu k problematice prípravy občanů k obraně státu nebyl podle šetření České školní inspekce nikdy vyslán žádný učitel z téměř 74 \% základních a středních škol v České republice),

- Ministerstvo obrany nemá v seznamu recenzentů sestavovaném dle vnitřního predpisu Ministerstva školství, mládeže a tělovýchovy19 žádného zástupce; existuje tak riziko možného udělení schvalovacích doložek učebnicím a učebním textům ze strany Ministerstva školství, mládeže a tělovýchovy bez odborného posouzení Ministerstvem obrany,

- v současném právním řádu nejsou nastaveny mechanizmy pro zajištění dostatečné odborné úrovně subjektů podílejících se na vzdělávání v oblasti prípravy občanů k obraně státu na školách a není tak garantována požadovaná kvalita a obsah tohoto vzdělávání,

- společné minimum stanovující minimální obsahové standardy pro profilující oblasti vzdělávání odborníků v oblasti bezpečnosti na vysokých školách již neodpovídá soudobým požadavkům a je žádoucí jej aktualizovat tak, aby všechny

4 Koncepce přípravy občanů k obraně státu. Praha: MO, 2019. 
žádosti o akreditaci studijních programů vysokých škol v oblasti bezpečnosti byly posuzovány jednotně,

- prezentace organizačních celků rezortu Ministerstva obrany na školách a na veřejnosti jsou obecně hodnoceny pozitivně, ze strany veřejnosti, médií a škol jsou však chybně zaměňovány za výuku, která by měla probíhat v rámci stanoveného vzdělávání,

Analýza provádění prípravy občanů $k$ obraně státu dále ukázala, že výrazně zastaraly také nástroje, prostřednictvím kterých se ve své nabídce stát obrací k občanům. Vyhodnocení splnění cílů stanovených Koncepcí príípravy občanů k obraně státu na roky 2013-2018 stejně jako uvedené skutečnosti zjištěné v rámci analýzy současného stavu provádění prípravy občanů $\mathrm{k}$ obraně státu byly využity při zpracování nové Koncepce na roky $2019-2024$.

Z uvedených skutečností byly stanoveny cíle nové Koncepce. Koncepce vychází z institucionálního chápání zajištování obrany a ze základního principu, že za prípravu a zajištování obrany státu odpovídá vláda, přičemž odpovídající díl odpovědnosti nesou rovněž ústřední správní úřady, správní úřady, orgány územních samosprávných celků a také samotní občané. Za vlastní prípravu občanů k obraně státu odpovídají ministerstva a jiné správní úřady v rozsahu stanoveném př́slušnými právními předpisy ${ }^{5}$, přičemž jeji řízení a stanovení jejího rozsahu a obsahu je $v$ gesci Ministerstva obrany. $V$ Koncepci je zdůrazněna klíčová role samotného občana a nutnost jeho aktivního, samostatného a zodpovědného př́stupu k získání nezbytných znalostí a k osvojení si dovedností a způsobů chování využitelných v př́padě jeho participace na zajištování obrany státu. Vedle osobní připravenosti občana $\mathrm{k}$ př́padnému plnění úkolů za vojenské krizové situace je $v$ míru hlavní motivací občana také možnost duálního využití získaných vědomostí a dovedností v osobním či profesním životě nebo v krizové situaci nevojenského charakteru.

Cílem Koncepce je popsat priority, směry dalšího vývoje a cílový stav systému přípravy občanů $k$ obraně státu $z$ hlediska celospolečenské potřeby ve všech jeho segmentech v období let 2019 až 2024. Kromě definování cílového stavu obsahuje Koncepce rovněž výčet konkrétních úkolů $\mathrm{k}$ zajištění její průběžné implementace prostřednictvím komplexního a vzájemně se doplňujícího přístupu ústředních správních úradů, správních úřadů a orgánů územních samosprávných celků. U každého úkolu je stanovena odpovědnost a uveden časový rámec jeho plnění.

Hlavním cílem koncepce je $s$ využitím různých nástrojů a postupů navést systém vedoucí ke zlepšení současného stavu prípravy občanů k obraně státu prováděné prostřednictvím vzdělávání na základních a středních školách, a to zejména cestou zkvalitnění prípravy současných i budoucích pedagogických pracovníků na provádění výuky předmětné problematiky. Dalším cílem, který Koncepce sleduje, je vytvoření systému dobrovolné prípravy občanů k obraně státu v míru mimo výkon branné povinnosti, včetně provedení souvisejících legislativních úprav.

5 Zákon č. 222/1999 Sb., o zajištování obrany České republiky, nebo zákon č. 585/2004 Sb., o branné povinnosti a jejím zajištování (branný zákon). 
Koncepce dále akcentuje důležitost využívání moderních informačních technologií a prostředků komunikace při otevřené distanční i tradiční prezenční formě vzdělávání.

\section{ROLE KRAJSKÝCH VOJENSKÝCH VELITELSTVÍ}

Krajská vojenská velitelství se na přípravě občanů k obraně státu podílejí zejména plněním funkce koordinační, metodické, vzdělávací, prezentační, informačně-komunikační, administrativní a kontrolní.

V rámci své teritoriální působnosti jsou krajská vojenská velitelství koordinátorem dílčích aktivit v oblasti př́pravy občanů $\mathrm{k}$ obraně státu, a to jak směrem k vojenským útvarům a zařízením, tak směrem k orgánům státní správy, územní samosprávy, školám, vzdělávacím zařízením, spolkům, církvím, náboženským společnostem a dalším právnickým osobám.

Vedle naplňování role koordinátora poskytují krajská vojenská velitelství při prípravě těchto aktivit rovněž nezbytnou metodickou pomoc, případně se na jejich praktické realizaci podílejí. Krajská vojenská velitelství podporují přípravu občanů k obraně státu přednáškovou a lektorskou činností, přičemž spolupracují s orgány státní správy a samosprávy, se školami, školskými zařízeními a jinými subjekty. V rámci dalšího vzdělávání pedagogických pracovníků organizačně a lektorsky zabezpečují bezplatná akreditovaná školení pro učitele základních a středních škol. Tato školení jsou organizována v každém kraji nejméně dvakrát ročně. Přednáškovou a lektorskou činnost na školách, ve školských zařízeních a v rámci dalšího vzdělávání pedagogických pracovníků provádí z pedagogického a odborného hlediska připravený personál.

\section{ZÁVĚR}

Koncepce je součástí struktury strategických a koncepčních dokumentů pro oblast bezpečnosti a obrany státu, jež společně vytvářejí podmínky pro realizaci opatření k zajištování obrany České republiky. Její implementace přispěje nejenom ke zvýšení úrovně připravenosti občanů na řešení celého spektra možných krizových situací bez ohledu na jejich charakter, ale také ke zvýšení kvality systému zajištování bezpečnosti a obrany České republiky.

Uvedení Koncepce do praxe je založeno na promítnutí v ní uvedených opatření do právního řádu České republiky a do koncepčních a plánovacích dokumentů jednotlivých věcně příslušných ministerstev a orgánů územní samosprávy. Dosažení popsaného cílového stavu je předpokládáno v roce 2024. 
Autor: $\quad$ Ing. Miroslav JURENKA, Ph.D., narozen v roce 1953.Absolvova vysokou vojenskou školu Vyškov. Pracoval na velitelských a štábních funkcích. $V$ roce 2001 zahájil pedagogickou činnost na Univerzitě obrany v Brně (Katedra rízení obrany státu, Ústav operačně taktických studií, Katedra krizového řízení). V současné době je akademickým pracovníkem Katedry vojenského umění Fakulty vojenského leadeshipu Univerzity obrany. Zabývá se problematikou obrany státu a krizového rízení.

Jak citovat: JURENKA Miroslav. Př́prava občanů k obraně státu. Vojenské rozhledy. 2019, 28 (3), 117-127. ISSN 1210-3292 (print), 2336-2995 (on-line). Available at: www.vojenskerozhledy.cz. 


\title{
Některé nástroje bezpečnostní politiky České republiky k zamezení proliferace jaderných a chemických zbraní
}

\section{Some Tools of the Czech Republic Security Policy to Prevent Proliferation of Nuclear and Chemical Weapons}

\author{
Martin Fokt, Antonín Novotný, Pavel Otřísal
}

Abstrakt: Článek se zabývá problematikou vybraných mezinárodních smluv, aktuálních dohod a iniciativ mezinárodní spolupráce v oblasti nešíření jaderných a chemických zbraní, ve kterých je zastoupena Česká republika prostřednictvím specifických orgánů nebo ministerstev. Je zde také rámcově popsán pohled a specifický vojenský přístup. Zapojení MO a AČR do struktur NATO umožňuje ovlivňovat strategické rozhodování v oblasti OPZHN a tím podporovat současné trendy týkající se forenzní analýzy, odběru CBRN vzorků a reakci na nové trendy v oblasti odstraňování následků použití ZHN.

Abstract: The article deals with selected international treaties, current agreements and international cooperation initiatives in the field of non-proliferation of nuclear and chemical weapons, in which the Czech Republic is represented through specific bodies or ministries. There is also a general description of the view and the specific military approach. The involvement of the MoD and the Czech Armed Forces in NATO structures enables to influence the strategic decision-making in the area of CBRN and thus support the current trends concerning forensic analysis, sampling of CBRN samples and response to new trends in the field of WMD elimination.

Klíčová slova: Kontrolní mechanismus; mezinárodní spolupráce; Nešíření ZHN; NTP; odzbrojení; OPCW; zneschopnění.

Keywords: Control Mechanism; International cooperation; Non - proliferation of WMD; NTP; disarmament; OPCW; disablement. 


\section{ÚVOD}

„ČR se zasazuje o prohlubování a zefektivňování procesů a mechanismů odzbrojení, kontroly zbrojení a nešiřeni zbraní hromadného ničení a jejich nosičù. $V$ návaznosti na prijietí nové Strategické koncepce NATO a opatření směřujících k posilení článku 5 Washingtonské smlouvy aktivně podporuje rozvoj a budování územní protiraketové obrany NATO a zkoumá možnosti konkrétního zapojení do tohoto systému. Rozvijí schopnosti bránit se proti hrozbě chemických, biologických, radiologických a jaderných zbraní hromadného ničení. $V$ rámci sdilení společných rizik a odpovědnosti v NATO pokračuje ve specializaci svých ozbrojených sil na oblast ochrany proti zbraním hromadného ničeni." ${ }^{1}$

Lidstvo si již od konce první světové války začalo uvědomovat potřebu omezit či zakázat používání chemických a biologických látek pro bojové použití v pojetí, jak je uvedeno v první Mezinárodní úmluvě o zákazu použití plynů a bakteriologických zbraní ve válce nazývaný také jako Ženevský protokol. Po druhé světové válce se $\mathrm{k}$ již známým zbraním s hromadným účinkem přidaly zbraně s nejničivějšími účinky - jaderné zbraně. Pro tyto zbraně se nadále vžil název „Zbraně hromadného ničení (ZHN).“ Tyto zbraně se staly fenoménem dvacátého století. $V$ době studené války udržovaly rovnováhu v bipolárním rozdělení světa na západní a východní blok.

$\checkmark$ devadesátých letech minulého století došlo $\mathrm{k}$ rozpadu bipolárního rozdělení světa a začala postupná multipolarizace světového zrízení. Tím se otevřel prostor pro další aktéry (státy a organizace) zasahovat do procesu proliferace ZHN. Především snaha nestátních aktérů o získání prístupu $\mathrm{k}$ technologiím, prekurzorům i již hotovým ZHN ovlivnila charakter celosvětové politiky proti šíření ZHN. Z hlediska šíření ZHN jsou nejrizikovějšími oblastmi Blízký a Střední východ a jižní a východní Asie. Šíření ZHN je usnadněno rostoucí dostupností znalostí a poznatků, technologií, materiálů dvojího užití a mobilitou vědců. ${ }^{2}$

Z pohledu mezinárodního společenství je problematika nešíření ZHN chápána jako jedna z významných oblastí potřebná k zachování ekonomické prosperity a politické stability v globálním kontextu. Omezení zbrojení a všestranné odzbrojení považuje OSN od svého vzniku za stěžejní předpoklad zachování míru a bezpečnosti ve světě. Přistoupení a prosazování úmluv a iniciativ $v$ této oblasti vedlo ke sní̌ení napětí v době bipolárního rozložení světa a přispělo ke konci studené války. Mírné snižení napětí v devadesátých letech vystřídal opětovný nárůst bezpečnostních rizik v oblasti šiření ZHN. Česká republika přistoupila k plnění těchto úmluv a dohod a implementovala tyto smlouvy do zákonů a nařízení, které zabezpečují právní rámec pro kontrolu a hospodaření s tímto nebezpečným materiálem.

1 Kolektiv autorů pod vedením Ministerstva zahraničních věcí ČR. Bezpečnostní strategie České republiky 2015. 1. Praha: Ministerstvo zahraničních věcí České republiky, 2015. Čl. 60. [cit. 2019-03-14] Dostupné z: https://www.vlada.cz/assets/ppov/brs/dokumenty/bezpecnostni-strategie-2015.pdf

2 SOUKENÍK, Petr. Politika proti proliferaci v České republice: Umístění v bezpečnostním systému a její aktéři. Brno, 2009. Bakalářská práce. FSS MU. Vedoucí práce doc. JUDr. PhDr. Miroslav Mareš, Ph.D. 
V ČR je zákonem č. 38/1994 Sb. zakázán obchod se zbraněmi jadernými, chemickými a biologickými, stejně jako s nosiči schopnými nést takové zbraně. ${ }^{3}$ Pŕímo související problematikou je kontrola vývozu položek dvojího užití, která je součástí práce mezinárodních kontrolních režimů.

ČR respektuje veškerá zbrojní embarga vyhlášená Organizací spojených národů (OSN), Evropskou unií (EU) a Organizací pro bezpečnost a spolupráci v Evropě (OBSE). Zároveň se aktivně podílí na jejich formulaci a aktualizaci v rámci mezinárodních organizací. Jako nejaderná země, členský stát OSN, EU, OBSE a NATO podporuje v rámci svých možností úsilí mezinárodního společenství o dosažení pokroku v řešení odzbrojovacích otázek $s$ konečným cílem, kterým je jaderné a všeobecné odzbrojení za účinné mezinárodní kontroly.

\section{MEZINÁRODNÍ SPOLUPRÁCE V OBLASTI ZAMEZENÍ PROLIFERACE ZHN}

\subsection{Pojem proliferace}

Proliferací rozumíme šíření ZHN a jejich nosičů a mezinárodně kontrolovaných položek. Pojem „proliferace“, správněji „non-proliferace“ představuje sledování aktivit orientovaných na získání strategických materiálů, zařízení, jednotlivých komponentů, technologií a know-how, použitelných k vývoji a výrobě ZHN (jaderných, chemických, biologických a radiologických), včetně jejich nosičů, a obranu proti těmto aktivitám. V této oblasti jsou sledovány i tzv. položky dvojího užití, tj. zboží a technologie, které jsou vyráběny primárně pro civilní použití, ale mohou být, vzhledem ke svému charakteru a vlastnostem, zneužity zejména $\mathrm{k}$ výrobě ZHN a jejich nosičů pro případné vojenské účely. Účelem kontroly vývozu zboží a technologií dvojího užití je zajistit, aby se toto zboží a tyto technologie nedostaly do států, které by je mohly využít v programech šírení ZHN nebo k organizacím, které by je mohly použít pro teroristické nebo vojenské účely. ${ }^{4}$

3 „Předmětem obchodu s vojenským materiálem nesmí být zbraně hromadného ničení, kterými se rozumí jaderné, chemické a biologické zbraně." § 4 zákona č. 38/1994 Sb. o zahraničním obchodu s vojenským materiálem.

4 BIS. [on line]. [cit. 1. 4. 2019]. Dostupné z: https://www.bis.cz/vojensky-material-a-proliferace/ 


\subsection{Pojem zbraně hromadného ničení}

Zbraněmi hromadného ničení označujeme takové zbraně, jejichž hlavním úkolem je usmrtit velké množství civilních i vojenských osob, způsobit velké ztráty na majetku a většinou zneschopnit velkou část území. Často bývají označovány jako nekonvenční zbraně. Rozdělují se na jaderné, chemické, biologické a radiologické zbraně. 5 Jiná definice je uvedena v názvoslovné normě CHV (NN 30 0101), která u pojmu zbraně hromadného ničení uvádí: „souhrnný výraz pro jaderné zbraně, chemické, biologické zbraně a radiologické zbraně. Jejich použití způsobuje masové ztráty osob, zničení materiálu a rozsáhlé škody v infrastruktuře."

a) Jaderné zbraně (JZ)

Jsou bojové prostředky využívající nukleární nebo termonukleární reakce. Rozlišují se na jaderné zbraně se sníženým podílem radioaktivity a jaderné zbraně se zvýšeným podílem radioaktivity. ${ }^{7}$ Jsou „,skutečnými“ zbraněmi hromadného ničení, a to kombinací velké destruktivní síly při samotné explozi a následného radioaktivního zamoření oblasti, elektromagnetického impulsu a tlakové vlny. V současné době platí Smlouva o všeobecném zákazu jaderných zkoušek. Smlouva je logickým doplňkem Smlouvy o zákazu zkoušek JZ v atmosféře, kosmickém prostoru a pod vodou z r. 1963, která ponechávala jako jedinou možnost provádění jaderných výbuchů v podzemí. Navazuje na další významný dokument v této oblasti - Smlouvu o nešíření JZ z roku 1968 - tím, že zabraňuje nejaderným státům, které by se prípadně rozhodly vyrobit vlastní JZ, tyto zbraně vyzkoušet a ověřit, jaderným státům pak jejích arzenály dále vyvíjet a zdokonalovat.

\section{b) Chemické zbraně}

Je to chemická munice, nebo speciální zařízení plněná bojovými chemickými látkami nebo jejich prekurzory, ${ }^{8}$ které mohou být vzhledem ke svým toxickým vlastnostem a použitému množství využity jako prostředky k vedení bojové činnosti. Mezi chemické zbraně patří:

- munice a další prostředky určené k usmrcení nebo způsobení újmy na zdraví člověka nebo zvířete, k poškození rostlin nebo ekosystémů, nastávají-li tyto účinky v důsledku toxických vlastností toxických chemických látek, které se z nich uvolňují;

- jakékoli zařízení zvlášt́ určené k použití uvedené munice a dalších prostředků. ${ }^{9}$

Jinými slovy - jsou to bojové prostředky využívající toxické nebo chemické látky za účelem zabití, zranění nebo paralyzace protivníka. Druhů chemických zbraní je velké

5 MIKA, Otakar, POLÍVKA, Lubomír a SABOL, Jozef. Zbraně hromadného ničení a ochrana proti jejich účinkům. Praha: Policejní akademie České republiky v Praze, 2009. str. 154. ISBN 978-80-7251-302-4

6 NN 30 0101. Chemické vojsko. Názvoslovná norma. 3. vyd. Praha: Ministerstvo obrany, 2009. $222 \mathrm{~s}$.

7 Ref. 6.

8 Úmluva o zákazu se týká i prekurzorů

9 Ref. 6 
množství, stejně tak existuje řada způsobů a prostředků jak zasáhnout případný cíl - rozprašováním, pomocí povětrnostní situace (vítr, déšt́), ale nejčastěji se používá munice s chemickou náplní. Př́kladem použití je raketa (střela, např. typu Scud), která nese hlavici s chemickou náplní. Vzhledem k velkému rozvoji chemického průmyslu bylo vyvinuto velké množství látek, které Ize vojensky využít. Jak vyplývá z výročních dokumentů organizace OPCW ${ }^{10}$ dochází $\mathrm{k}$ likvidaci zásob těchto látek dle předem stanovených dohod. Přes veškerou snahu stále dochází k incidentům s použitím chemických zbraní. Příkladem je i současný konflikt v Sýrii, kde obě strany byly obviněny z použití bojových otravných látek v letech $2013^{11}$ nebo použití toxické látky dne 7. dubna 2018 obsahující reakceschopný, pravděpodobně molekulární chlór. $K$ tomuto závěru vyšetřovatelé dospěli pomocí poznatků získaných přímo v místě, svědeckých výpovědí, analýzy odebraných vzorků a konzultací s experty např. na balistiku a mechaniku. ${ }^{\mathbf{1 2}}$

Toxické látky z kategorie bojových chemických a vojensky významných průmyslových chemických látek mohou být i zneužity k destabilizaci mezinárodních vztahů. Typickým případem zneužití schopností bojové chemické látky je případ dvojitého agenta Sergeje Skripala a jeho dcery. Z použití nervově paralytické bojové chemické látky 4 . generace (Novičok), mající některé fyzikální a toxické charakteristiky podobné látce $V X$ ve městech Salisbury a Amesbury v roce 2018 byli obviněni agenti ruské zpravodajské služby. Jedná se o novou situaci, která vyžaduje i odpovídající reakci mezinárodního společenství. Ani v České republice, jednom z 29 členských států NATO, nejsou pro přiměřenou reakci na tuto situaci dosud vytvořeny plně fungující technické a taktické procedury. Proto je nutné připravit vojenské doporučení k budování nezbytných schopností, kde hraje rozhodující roli NATO JCBRN CDG. ${ }^{13} \mathrm{~K}$ tomu je nutné vybudovat audit schopností NATO využitelných pro eliminaci útoků s použitím Novičoku a připravit návrh na výstavbu dalších aliančních k tomu potřebných schopností. V rámci International Military Staff NATO by mělo dojít k vypracování počátečního hodnocení a doporučení pro Alianci k operacionalizaci zkušeností z útoků ve Velké Británii. ${ }^{14}$

10 Organisation for the Prohibition of Chemical Weapons

11 ARMBRUSTER, Ben; BROWN, Hayes. How We Got There: A Timeline of the Chemical Weapons Saga. THINKPROGRESS[online].CenterforAmericanProgressFund, publikováno28.8.2013[cit.1.4.2019].Dostupné z: http://thinkprogress.org/security/2013/08/28/2539341/syria-chemical-weapons-saga/

12 Zpráva OPCW konstatuje, že informace nashromážděné během uplynulých měsíců poskytují důvodný základ pro konstatování, že v syrském Dúmá došlo 7. dubna 2018 k chemickému útoku toxickou látkou. Vyšetřovatelé neměli mandát, kdo je za útok zodpovědný, tuto pravomoc bude mít až nově zřizovaný tým v rámci OPCW, který začne fungovat $v$ nejbližši době - viz OPCW Technical Secretariat. Report of the fact-finding mission regarding the incident of alleged use of toxic chemicals as a weapon on Douma, Syrian Arab Republic, ond 7 April 2018. 106 s. [cit. 1. 4. 2019]. Dostupné z: https://www.opcw.org/sites/default/files/documents/2019/03/s-1731-2019\%28e\%29.pdf

13 JCBRN Defence COE. [cit. 1. 4. 2019]. Dostupné z: https://www.jcbrncoe.cz/index.php/events-67/ main-events-2018/454-joint-chemical-biological-radiological-nuclear-defence-

capability-development-group-spring-2018-meeting

14 SD ČR. Denní souhrn záznamů jednání SD ČR při NATO ze dne 11. 3. 2019. Dostupné z: ŠIS 


\section{c) Radiologické zbraně}

Jsou zbraně, které využívají škodlivé účinky ionizujícího záření. Při výbuchu neprobíhá jaderná reakce, dojde pouze $\mathrm{k}$ rozmetání radionuklidů do prostoru. ${ }^{15}$ Mohou se vyskytovat dva druhy zařízení. Radiologické disperzní zařízení (RDZ) mohou šírít nebo rozptýlit radioaktivní látky (materiál), za účelem vytvořit radioaktivní kontaminaci, která by mohla zamezit nebo snížit vojenské operace. Radiologické expoziční zařízení (RED) jejich účelem je kontaminovat lokalizovanou oblast osoby v jejich okolí. ${ }^{16}$ Další možné ohrožení může pocházet $z$ radioaktivních materiálů uvolněných průmyslovou činností nebo $z$ použité munice. $Z$ vojenského hlediska jsou tyto zbraně málo účinné a v arzenálech armád se nevyskytují. V případě radiologického materiálu můžeme hovořit o zneužití tohoto materiálu pro výrobu tzv. špinavé bomby, kdy je sestrojeno kombinované improvizované výbušné zařízení složené z výbušniny a radiologického materiálu, který je výbuchem rozmetán po okolí. Efekt těchto „zbraní“ je spíše v psychologickém působení na obyvatelstvo, než ve vlastním kontaminování terénu, či osob. Přesto nelze zcela toto nebezpečí ignorovat.

\section{PŘíSTUPY MEZINÁRODNÍHO SPOLEČENSTVÍ}

Je nesporným a často zmiňovaným faktem, že šíření zbraní hromadného ničení a jejich nosičů je největší globální bezpečnostní hrozbou zejména v souvislosti s narůstajícím mezinárodním terorizmem, a to jak skupinového, tak i individuálního charakteru. Všeobecně panuje vzájemná shoda $v$ rámci mezinárodního společenství $k$ této problematice, přesto jsou tu zde dvě hlavní myšlenkové koncepce kooperativní bezpečnostní prístup podporovaný OSN a kontra proliferační (nešíření) prosazovaný zejména administrativou USA.

\subsection{Kooperativní bezpečnostní př́stup}

Je princip založený na právním režimu, spolu se závaznými mnohostrannými dohodami a verifikačními mechanizmy je považován za nejlepší cestu k míru a stabilitě. Stabilita a predvídatelnost $v$ mezinárodních vztazích je primární cíl suverénního státu. Kooperativní škola myšlení vychází z toho, že státy a nestátní aktéři mohou usilovat o ZHN z důvodu prestiže a postavení za účelem postavit svět před skutečnost, že nyní musí s těmito aktéry jednat (KLDR, Irán). Současně uznává, že snaha o získání ZHN může vyústit do nezákonného ozbrojování. Přesto jsou stoupenci této strategie přesvědčeni, že státy budou hledat větší relativní bezpečnost prostřednictvím vzájemných závazků k omezení svých vojenských kapacit.

15 Ref. 6

16 Ref. 6 
V prípadě otázky šíření ZHN a jejich nosičů je nezbytné vyvíjet iniciativy jak ze strany těch, kteří mají k dispozici příslušné technologie, tak těch kteří o získání těchto technologií usilují. Aktivity vlastníků technologií zahrnují horizontální neproliferační opatření, jako jsou vývozní kontroly, stejně tak jako vertikální odzbrojení ze strany států vlastnící ZHN. Aktivity států toužících po technologiích by měly vést ke zmírnění základních príičin vzniku požadavku na získání příslušných technologií, a to prostřednictvím zajištění bezpečnosti, rozvoje, spravedlnosti a nestranných iniciativ vůči nim. Velmoci by se měly vyvarovat takových akcí, které by podporovaly úsilí odběratelských států o získání ZHN. Například se jedná o pokusy zachovat a udržet zásoby ZHN, což by mohlo přispět ke zvýšení šíření ze strany slabších odběratelských států, které by se cítily těmito arzenály ohrožovány.

\subsection{Kontra proliferační strategie}

Tato myšlenka byla prvně formulována bývalým ministrem obrany Les Aspinem za volebního období amerického prezidenta Bila Clintona. Původně byl tento přístup označen za doplňující aktivitu iniciativám založeným na globálních neproliferačních režimech. Avšak v současné době se koncepce nešíření téměř výlučně zaměřila na kontra proliferační politickou linii vycházející z obecného závěru, že kontrolně zbrojní a odzbrojovací režimy málo přispívají mezinárodnímu míru a bezpečnosti. Kontra proliferační strategie vychází ze selektivního multilateralismu USA, jejich prátelé a spojenci budou pružně používat směs dodavatelských vývozních kontrol, odstrašení, nátlakové diplomacie globální vojenské nadřazenosti a preventivního či spíše preemptivního použití vojenské síly. Vztahy USA jsou široce definovány v termínech formálních nebo neformálních aliancí a bezpečnostního porozumění s práteli, kteří dostávají preferenční americkou pomoc.

Hlavní aspekty kontra proliferačního prístupu USA k hrozbám použití ZHN spočivají v odhodlání:

- vyvinout aktivní úsilí k identifikaci proliferační hrozby, které přímo ohrožují americké zájmy a národní bezpečnost, nečekat a nedovolit aby se samy identifikovaly;

- jednat za účelem neutralizace identifikovaných hrozeb a v případě potřeby i s použitím preemptivních vojenských úderů;

- na obranu amerických zájmů a národní bezpečnosti v prípadě potřeby jednostranně zasáhnout proti proliferačním hrozbám;

- udržovat otevřené všechny volby ve vztahu ke zničení kapacit ZHN protivníka, včetně použití a vývoje nových jaderných zbraní. Pro tento účel si ponechat otevřenou volbu pro první použití JZ i proti státům, které JZ nevlastní;

- ve zvýšené míře nadále spoléhat na normativní zásadu předběžné sebeobrany, která vznikla v důsledku teroristického útoku z 11. 9. 2001 a na základě měnícího se způsobu analýzy hrozeb.

V současné době někteří političtí analytici navrhují variantu třetí koncepce, či strategie střední cesty mezi kooperativní a kontra proliferační školou myšlení. Avšak žádná 
taková koncepce nebyla ještě definována takovým způsobem, který by umožnil provést její srovnávací analýzu. ${ }^{17}$

\section{VYBRANÉ MEZINÁRODNÍ SMLOUVY A INICIATIVY}

Efektivní nástroj pro proliferaci ZHN jsou mezinárodní úmluvy a iniciativy $v$ oblasti nešíření ZHN. Také Česká republika k nim v průběhu let přistoupila a na základě těchto dohod upravila vlastní národní legislativu.

\subsection{SMLOUVA O NEŠíǐení, OdZBROJENí A MÍROVÉM VYuŽití JADERNÉ ENERGIE}

Riziko proliferace jaderných zbraní je stále aktuální, proto zůstává základním dokumentem eliminace tohoto jevu Smlouva o nešíření jaderných zbraní „Treaty on Non-Proliferation of Nuclear Weapons - NPT.“18 Tento světový režim nešírení je zcela nezbytný pro postupné jaderné odzbrojování.

Bývalé Československo se stalo signatářem Smlouvy o nešíření jaderných zbraní v roce 1968 a ratifikovalo ji o rok později. Po rozpadu federace ke smlouvě přistoupila ČR a prèvzala veškeré závazky z ní vyplývající. ČR podporuje realizaci všech článků této smlouvy, včetně jejího čl. VI vyzývajícího $\mathrm{k}$ uzav̌rení smlouvy o všeobecném a úplném jaderném odzbrojení za přísné a efektivní mezinárodní kontroly. $Z$ tohoto hlediska ČR, jako nástupnický stát hlasovala na klíčových zasedáních Valného shromáždění OSN v devadesátých letech ve prospěch rezolucí OSN jako "Jaderné odzbrojení z hlediska úplné eliminace jaderných zbrani“ a „Bilaterální jednání o jaderných zbraních a jaderné odzbrojení". Zmíněné rezoluce mj. vyzývají jaderné státy ke snižování jaderných zbraní až k úplnému jadernému odzbrojení a všechny státy $\mathrm{k}$ jadernému odzbrojení pod přísnou mezinárodní kontrolou. Zároveň ČR uznává, že jaderné odzbrojení je složitý a dlouhodobý proces, který nesmí ohrozit bezpečnostní rovnováhu ve světě a vytvářet nová rizika.

17 TŮMA, Miroslav. Nešiření zbraní hromadného ničení v kontextu aktuálních otázek mezinárodní bezpečnosti a boje proti terorismu. 1. vydání. Brno: Ústav strategických studií Univerzity obrany, 2004. ISBN 80-85960-90-7.

18 UNODA. Treaty on the Non-Proliferation of Nuclear Weapons (NPT). [cit. 1. 4. 2019]. Dostupné z: https://www.un.org/disarmament/wmd/nuclear/npt/text 


\section{2 Úmluva o zákazu vývoje, výroby, hromadění zásob a používání chemických zbraní}

Úmluva o zákazu vývoje, výroby, hromadění zásob a použití chemických zbraní a jejich zničení, zkráceně Úmluva o zákazu chemických zbraní byla přijata 13. ledna 1993 a vstoupila v platnost po ratifikaci 65 smluvními státy dne 29. dubna 1997. Hlavními cíli Úmluvy (Convention on the Prohibition of the Development, Production, Stockpiling and Use of Chemical Weapons and on Their Destruction - CWC ${ }^{19}$ jsou likvidace chemických zbraní, kontrola dodržování zákazu chemických zbraní, pomoc a ochrana proti chemickým zbraním a mezinárodní spolupráce v hlavních oblastech působnosti Úmluvy. Úmluva má 188 smluvních států a 2 státy-signatáŕe, které ji ještě neratifikovaly (Izrael, Barma/ Myanmar). Pět zemí Úmluvu nepodepsalo (Angola, Egypt, KLDR, Somálsko, Sýrie).

ČR podepsala Úmluvu dne 14. ledna 1993, dne 6. března 1996 ji ratifikovala a plně zajištuje své závazky vyplývající z Úmluvy. Naplňování Úmluvy je důsledně realizováno na základě právního a institucionálního rámce. Národním úřadem a gestorem pro provádění Úmluvy v ČR je Státní úřad pro jadernou bezpečnost (SÚJB).

Na základě Úmluvy vznikla v květnu 1997 Organizace pro zákaz chemických zbraní (OPCW) se sídlem v Haagu. Má tři hlavní orgány - Konferenci smluvních států (složenou ze všech smluvních států, zasedání se koná jednou ročně), Výkonnou radu (složenou ze 41 států, má 4 pravidelná zasedání ročně, může se scházet k mimořádným zasedáním podle potřeby) a Technický sekretariát.

ČR patří mezi zakládající členy OPCW, všestranně podporuje její poslání a aktivně se na činnosti OPCW podílí. V letech 1998-2000, 2003-2005, 2007-2009 a 2012-2014 byla členem Výkonné rady OPCW. ČR prosazuje dosažení univerzality Úmluvy, důslednou realizaci ustanovení Úmluvy v národních legislativních systémech smluvních stran, sjednocení pravidel a technických náležitostí pro hlášení (deklarace) o exportu, importu a výrobě chemických látek a zvyšování efektivity činnosti OPCW, včetně účinnosti a kvality inspekcí. ČR spolupracuje s OPCW v oblasti školení, kursů a seminářu. Významnými pro rozvoj a úroveň spolupráce ČR s OPCW i z hlediska právní úpravy se staly Dohoda mezi ČR a OPCW o inspekcích na místě v objektu pro ochranné účely seznamu 1 chemických látek, která byla podepsána 15. 6. 2011 v Haagu a vstoupila v platnost dnem 13. února 2012, a Dohoda mezi ČR a OPCW o výsadách a imunitách, podepsaná rovněž 15. června 2011, která vstoupila v platnost dnem 1. května 2012.20

19 OPCW. Convention on the Prohibition of the Development, Production, Stockpiling and Use of Chemical Weapons and on Their Destruction - CWC. [cit. 1. 4. 2019]. Dostupné z: https://www.opcw.org/chemical-weapons-convention.

20 MZV ČR. Chemické zbraně. [cit. 1. 4. 2019]. Dostupné z:

https://www.mzv.cz/jnp/cz/zahranicni_vztahy/bezpecnostni_politika/cr_a_odzbrojeni/zbrane _hromadneho_niceni/chemicke_zbrane/index.html. 


\section{EVROPSKÁ UNIE A NEŠŚŘENÍ ZHN}

Problematika nešíření ZHN a postoje EU k této problematice jsou zakotveny v druhém pilíri, který zahrnuje společnou zahraniční a bezpečnostní politiku (SZBP). Tato politika se neustále vyvíjí a reaguje na vývoj evropské i mezinárodní situace. SZBP se týká oblastí, která je považována tradičně za důležitou součást suverenity států. To je jeden z důvodů, proč integrace $v$ této oblasti postupuje pomaleji a rozvíjí se na bázi mezivládní spolupráce, která vyžaduje souhlasný přístup všech zúčastněných států a nevede k vytváření nadstátních orgánů a institucí. Rozhodující úlohu při její formulaci a uskutečňování mají členské státy, orgány Unie plní v podstatě roli vykonavatele politiky dohodnuté členskými státy.

Dohoda o SZBP v rámci EU neznamená, že by se členské státy vzdávaly práva provádět vlastní zahraniční politiku. Zavazují se však, že ve své politice budou přihlížet $k$ společně dohodnutým př́stupům a postupům $v$ rámci Unie. To jim umožňuje na mezinárodních fórech mluvit jedním hlasem, pokud si to přejí. Mohou jednat společně a využívat k tomu ekonomického, politického a obranného potenciálu svých zemí i potencionálu Unie. Výhody společného postupu jsou v tom, že společně lze lépe a účinněji čelit novým hrozbám, jako je šíření ZHN, ilegální obchod se zbraněmi a jadernými materiály, fundamentalismus a extremismus. ${ }^{21} \mathrm{~V}$ roce 2008 přijala Rada ministrů zahraničí členských států EU Společný postoj 2008/944/SZBP,22 kterým se stanoví společná pravidla pro kontrolu vývozu vojenských technologií a vojenského materiálu. Tento dokument obsahuje ve svém druhém článku osm kritérií, podle kterých je v členských státech hodnocen každý vývoz zbraní. Jedná se o kritéria, které v roce 1998 přijaly státy EU jako politicky závazný Kodex chování EU při vývozu zbraní. ${ }^{23}$ Česká republika již během roku 2009 implementovala principy Společného postoje 2008/944/SZBP24 a zohlednila je při novelizaci své národní legislativy.

Rozhodnutím Rady EU SZBP zřídila v červenci 2010 „Evropskou sít nezávislých expertů pro nešíření jaderných zbraní na podporu provádění strategie Evropské unie proti šíření ZHN“. Konsorcium EU pro nešíření jaderných zbraní je sít', která sdružuje instituce zahraniční politiky a výzkumná střediska z celé EU s cílem podpořit dialog týkající se bezpečnosti a dlouhodobou diskusi o opatřeních pro boj proti šíření ZHN a jejich nosičů. Mandát konsorcia a expertní sítě se neomezuje pouze na otázky týkající se zbraní hromadného ničení, ale zahrnuje také konvenční zbraně, včetně ručních palných a lehkých zbraní (SALW). Konsorcium pořádá a organizuje zasedání odborníků, významné každoroční mezinárodní konference, ad hoc semináře, a vytváří a rozvíjí specializované webové stránky a odborné publikace. Konsorcium také nabízí vzdělávací aktivity, jako například

21 Ref. 17, str. 58-59

22 EU. Společný postoj rady 2008/944/SZBP. [cit. 1. 4. 2019]. Dostupné z: https://eur-lex.europa.eu/lega I-content/CS/TXT/PDF/?uri=CELEX:32008E0944\&from=EN

23 EU Code of Conduct on Arms Exports. Vžitý český překlad neodpovídá přesně významu, nebot Kodex pokrývá nejen oblast zbraní, ale celou oblast vojenského materiálu.

24 Řada členských států (napríklad Německo) zavedla do své legislativy již dríve kritéria Kodexu chování EU 
e-lerningové kurzy. V neposlední řadě na žádost EU zpracovává Konsorcium expertízy v oblasti proliferace pomocí vytvořené informační linky. Od roku 2018 je Konsorcium odpovědné i za organizaci výcviku v oblasti proliferačního povědomí. ${ }^{25}$

\subsection{Legislativa České republiky}

Stěžejním zákonem v oblasti jaderné bezpečnosti je zákon č. 263/2016 Sb. Atomový zákon. Tento zákon zapracovává příslušné předpisy Evropského společenství pro atomovou energii (Euratom) a Evropské unie, zároveň navazuje na přímo použitelné předpisy Euratomu a Evropské unie a upravuje podmínky mírového využíání jaderné energie, podmínky vykonávání činností v rámci expozičních situací, nakládání s radioaktivním odpadem a vyhořelým jaderným palivem, schvalování typu některých výrobků v oblasti mírového využívání jaderné energie a ionizujícího záření a podmínky přepravy radioaktivní nebo štěpné látky, radioaktivního odpadu nebo vyhořelého jaderného paliva, monitorování radiační situace, zvládání radiační mimořádné události, podmínky zabezpečení jaderného zařízení, jaderného materiálu a zdroje ionizujícího záření, požadavky k zajištění nešíření jaderných zbraní a výkon státní správy v oblasti mírového využívání jaderné energie a ionizujícího záření. Dalším zákonem je Zákon č. 255/2012 Sb., o kontrole (kontrolní rád).

Oblast chemických zbraní je v české legislativě zakotvena v zákoně č. 19/1997 Sb., který aplikuje ustanovení Úmluvy o zákazu vývoje, výroby, hromadění zásob a použití chemických zbraní a o jejich zničení do právních podmínek ČR, zakazuje vývoj, výrobu a dovoz chemických zbraní, stanovuje podmínky udělování licencí pro nakládání s vysoce nebezpečnými látkami, stanoví povinnosti při nálezu chemických zbraní a vysoce nebezpečných látek, ohlašování stanovených látek, jejich evidenci a stanovuje druhy sankcí za porušení zákona. ${ }^{26}$

\subsection{Civilně - politický aspekt}

Česká republika jako signatář smluv a iniciativ pro nešíření ZHN a zároveň aktivní člen Aliance v oblasti OPZHN (CBRN) přistupuje k úkolu non-proliferace ZHN velmi aktivně a odpovědně. Problematikou se zabývá Ministerstvo zahraničních věcí jako garant zahraniční a bezpečnostní polity státu. Pokud chápeme non-proliferaci ZHN jako politický nástroj pro dosažení stanoveného cíle pomocí dodržování smluv a ujednání, jsou v ČR parametry nastaveny dle všech standardů. Na ministerstvu zahraničních věcí se touto problematikou zabývá Odbor bezpečnostní politiky. Odbor odpovídá komplexně za

25 EU. [online]. [cit. 1. 2019]. Dostupné Z: https://www.nonproliferation.eu/thematics/european-union-policies/ 26 SÚJB. [cit. 1. 4. 2019]. Dostupné z: https://www.sujb.cz/nesireni-jadernych-zbrani/. 
vztahy s NATO. Odborně řídí Stálou delegaci ČR při NATO. Odpovídá za zapojení ČR společné bezpečnostní a obranné politiky EU, odpovídá za koordinaci stanovisek $\mathrm{k}$ vojenským aspektům CSDP s MO a v neposlední řadě zajištúuje účast ČR v procesu kontroly zbraní jak konvenčních tak ZHN a jejich nosičů.

Hlavním kontrolním orgánem pro vymáhání a dodržování smluv o nešírení ZHN je SÚJB, který pro zabezpečení své zákonné povinnosti vytvořil Odbor pro kontrolu nešíření ZHN, který se dál dělí na oddělení pro kontrolu nešíření jaderných zbraní a oddělení pro kontrolu zákazu chemických a biologických zbraní. ${ }^{27}$

\section{PŘ́íSTUP NATO K PROBLEMATICE NEŠíǐ́ENÍ ZHN}

Základním posláním NATO je ochrana svobody a bezpečnosti všech jeho členů politickými i vojenskými prostředky v souladu se zásadami Charty OSN. Od samého počátku své existence pracuje Aliance na vytvoření spravedlivého a trvalého mírového pořádku v Evropě, založeného na společných hodnotách demokracie, lidských práv a právního státu. Tento ústřední cíl Aliance znovu nabyl na významu po skončení studené války, nebot vyhlídka na jeho dosažení se poprvé v poválečných dějinách Evropy jeví reálnou.

K dosažení tohoto cíle se Aliance zabývá i problematikou nešíření ZHN. Tato problematika je zakotvena ve Strategickém konceptu z roku 2010 nazvaném „Strategic Concept for the Defence and Security of the Members of the North Atlantic Treaty Organization. ${ }^{.28} \mathrm{~V}$ tomto dokumentu se vymezuje k problematice nešíření takto: Kontrola zbrojení, odzbrojení a nešíření přispívají k míru, bezpečnosti a stabilitě a měla by zajistit bezpečí pro všechny členy Aliance. Budeme i nadále hrát svou roli při posilování kontroly zbrojení a při podpoře odzbrojení jak konvenčních zbraní, tak zbraní hromadného ničení, jakož i úsilí o nešiření zbraní hromadného ničení. Nadále bude Aliance zkoumat způsoby, jakým politické prostředky a vojenské schopnosti přispějí k mezinárodnímu úsilí v boji proti šíření zbraní včetně ZHN.

Stěžejním dokumentem $v$ této oblasti je Komplexní strategická politika NATO pro předcházení šiření zbraní hromadného ničení a obraně před ohroženími chemickými, biologickými, radiologickými a nukleárními (CBRN) z roku 2009, kde hlavní myšlenkou je teze, že při náležitém respektování hlavního vojenského poslání Aliance bude NATO aktivně usilovat o zabránění šiření zbraní hromadného ničení ze strany státních a nestátních subjektů. Chránit Alianci v prípadě že toto úsilí selže a být připraven na obnovu území zasažené ZHN nebo CBRN incidentem v rámci svých kompetencí a kdykoli může přinášet přidanou hodnotu prostřednictvím komplexního politického, vojenského a civilního přístupu NATO bude i nadále zvyšovat hodnotu úsilí o nešíření jaderných zbraní

27 SÚJB. Výroční zpráva 2017. [cit. 1. 4. 2019]. Dostupné z: https://www.sujb.cz/fileadmin/sujb/docs/ zpravy/vyrocni_zpravy/ceske/Zprava-cinnost-SUJB-2017-Cast_I.pdf.

28 NATO. Strategic Concept for the Defence and Security of the Members of the North Atlantic Treaty Organization. [cit. 1. 4. 2019]. Dostupné z: https://www.nato.int/nato_static_fl2014/assets/pdf/pdf_publications/20120214_strategicconcept-2010-eng.pdf 
podporou rozvoje schopností spojenců zabraňovat nebo zastavovat obchodování se ZHN, souvisejícími materiály a jejich nosiči. Tyto schopnosti by mohly být využity v námořních operacích zaměřených na omezení obchodování s těmito materiály. Aliance by navíc mohla své vojenské schopnosti přinést do procesu při odhalování, identifikaci, sledování, akvizic nebo vývoje ZHN. Vést informační operace na vyloučení, odrazování a odmítání šíření zbraní hromadného ničení. Zahájit zpravodajskou výměnu informací mezi spojenci a prípadně i partnery za účelem vypracování informačních zpráv pro činnost v oblasti nešíření ZHN. Aliance může také rozvíjet a podporovat společné provozní normy, koncepce, doktríny a taktiky a také podporovat nebo usnadňovat př́slušné školení a cvičení v této oblasti. A konečně, NATO posílí mezinárodní dosah, aby podpořilo související schopnosti partnerů a posílil globální reakci na př́ipadné šíření ZHN. ${ }^{29}$

\subsection{Vojenský pohled na problematiku nešíření}

Z vojenského pohledu je problematika non-proliferace ZHN spíše chápána jako oblast politická, Aliance se príklání spíše k pojmu prevence šíření ZHN. V letošním roce byl představen nový př́stup v této oblasti, jedná se o Komplexní strategii NATO pro předcházení, zneschopnění (disablement) šíření zbraní hromadného ničení a obraně proti chemickým, biologickým, radiologickým a nukleárním hrozbám (Weapons of Mass Destruction Disablement Functional Concept). Tento koncept zavádí systematický a komplexní př́stup k prevenci šíření zbraní hromadného ničení a k obraně proti CBRN hrozbám.

Pojem zneschopnění (disablement) ZHN je definován jako operace, jejichž cílem je systematicky lokalizovat, zabezpečit, odstranit nebo zlikvidovat ZHN, chemické zbraně, CBRN zařizení a materiál, anebo schopnosti na výzkum, vývoj, testování, výrobu a skladování, včetně zbraní prístrojů a materiálu potenciálních protivníků.

Koncept komplexní CBRN ochrany (The Comprehensive CBRN Defence Concept) spojuje požadované oblasti pro zabezpečení CBRN ochrany, jakož to i príslušné úkoly spojené s třemi piliŕi prevence, ochrana a obnova (obrázek č. 1) a dále definuje schopnosti potřebné k naplnění těchto úkoli̊. Slouží k posouzení toho, jak může NATO lépe bojovat proti šiření ZHN a způsobu jejich šiření, přezkoumává aktuální požadavky na ochranu v oblasti CBRN zabezpečení, včetně politického zadání a identifikuje oblasti pokroku a nedostatky. Uznává, že obranný plánovací proces NATO je důležitým mechanismem, kterým NATO identifikuje nedostatky v kapacitách a zajištuje, aby Aliance mohla účinně reagovat na hrozby. Operační schopnosti k odrazení, odhalení, narušení a zabránění šíření ZHN a reakce na krizové situace $v$ oblasti CBRN mohou ztižit šíření ZHN a vylepšit postoj NATO pro efektivní reakci. Posouzení obsahuje praktická doporučení, která Ize

29 NATO. NATO's Comprehensive, Strategic-Level Policy for Preventing the Proliferation of Weapons of Mass Destruction (WMD) and Defending against Chemical, Biological, Radiological and Nuclear (CBRN) Threats. [cit. 1. 4. 2019]. Dostupné z: https://www.nato.int/cps/en/natolive/ official_texts_57218.htm 
uplatnit, aby se mohly řešit nedostatky v každé $z$ těchto oblastí. ${ }^{30}$ Koncept komplexní CBRN ochrany NATO vytváŕí vazbu mezi politicko - strategickou úrovní a vývojem schopností na taktickém stupni. $V$ neposlední řadě pomůže ujednotit poznatky $v$ oblasti doktrín, organizace, výcviku, materiálu, normách a operacích.

\section{KOMPLEXNÍ KONCEPCE CBRND NATO}

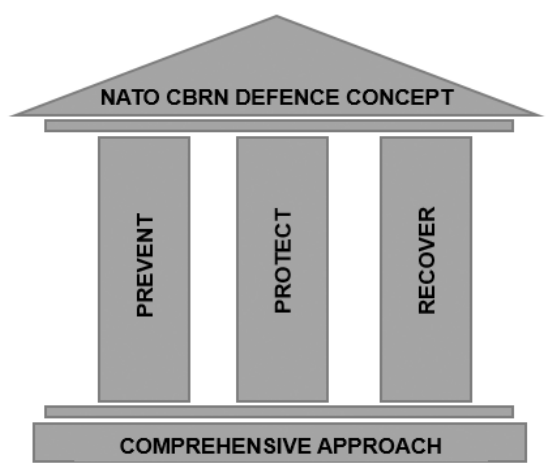

Obrázek č. 1: Comprehensive CBRN concept

\section{1. 1 Koncept komplexní CBRN ochrany pilír PREVENT ( $p$ řed cházet )}

Tento pilíř zahrnuje diplomatické úsilí, politické kroky zamezení šíření a zneužívání ZHN včetně nosičů ZHN, zpravodajskou činnost a v neposlední řadě i vojenský preventivní zásah proti aktérovi který má možnost použít ZHN. Veřejná diplomacie a strategická komunikace jsou strategickými faktory, které ovlivňují vnímání na globální, regionální a národní úrovni. Propagace silné informační kampaně může pomoci odradit potenciálního protivníka od získání a používání ZHN tím, že podtrhuje náklady a rizika spojená s pořizováním a používáním zbraní hromadného ničení. Strategická informační kampaň rovněž informuje o komplexním přístupu NATO k řešení hrozby ZHN a podporuje vyšší úroveň povědomí veřejnosti o prríspěvcích NATO v oblasti nešíření zbraní, kontroly zbraní a odzbrojení.

Komplexní shromažd’ování informací a jejich konzistentní posouzení jsou základním aspektem zpravodajství zaměřeným na ZHN a CBRN Reachback (zpětnou vazbu). Zahrnuje operační nebo taktické zjišt́ování CBRN hrozeb, forenzní charakteristiku zařízení pro výrobu ZHN. Aliance si vzala za cíl investovat finanční zdroje s cílem zlepšit schopnost

30 NATO. Lisbon Summit Declaration. [cit. 1. 4. 2019]. Dostupné z:

https://www.nato.int/cps/en/natolive/official_texts_68828.htm\#wmd 
Aliance detekovat, charakterizovat ohrožení, vytvořit struktury pro zpětnou vazbu prostor pro předběžné plánování, přiřadit schopnosti se zaměřením na včasné varování před použitím ZHN nebo CBRN incidentem s cílem posílit obranné a ochranné postupy Aliance. CBRN Reachback je nezbytnou součástí celého spektra NATO aktivit při prosazování principů šíření ochrany a obnovy při prípadném použití ZHN. V tomto procesu sehrává velkou roli COE CBRN Vyškov. ${ }^{31}$ CBRN Reachback je definován jako proces, kterým mohou být nasazené síly vybaveny včasnými, koordinovanými autoritami a podrobnými informacemi o chemických, biologických, radiologických, jaderných a jiných rizicích CBRN včetně ochranných protiopatřeních využívajících vzdálené odborné zdroje informací. Účinná reakce CBRN by měla podporovat celé spektrum reakce NATO na šíření, ochranu a obnovu po použití ZHN. Použití vojenské síly pro odrazení použití ZHN je chápáno jako poslední možnost v případě, kdy selhaly všechny politické, ekonomické a informační prostředky.

\section{1. 2 Koncept komplexní CBRN ochrany pilír PROTECT ( och rana)}

Tento pilír je plně v gesci vojenských složek. Vyrovnaná kombinace sil, schopnost reakce a posílení obrany a ochrany je zapotřebí k odvrácení a odstrašení snahy před použitím zbraní hromadného ničení. Vzhledem k potenciálně ničivým důsledkům používání zbraní hromadného ničení musí být zavedeny rozsáhlé pasivní obranné a zmírňující opatření, které umožňují silám NATO pokračovat v účinných vojenských operacích v kontaminovaném prostředí a umožnit NATO a př́slušným civilním agenturám pomáhat spojencům a partnerům s odstraňováním a snižováním následků použití ZHN. Druhý pilír zahrnuje včasnou detekci a identifikaci CBRN látek, varování a uvědomování jednotek, opatření k vyhnutí se př́padné kontaminace obejitím kontaminovaného prostoru, včasné a správné používání prostředků individuální a kolektivní ochrany a včasná dekontaminace zasažených jednotek a materiálu.

\section{1. 3 Koncept komplexní CBRN ochrany pilír RECOVER ( ob nova)}

Pokud se nepodaří předejít nebo zabránit použití ZHN, NATO musí být plně připraveno se zotavit z důsledků jejich použití proti obyvatelstvu, území a jednotkám, at' už ze strany nepřátelských států nebo teroristů, stejně tak, pokud by členové nebo partneři Aliance byli postiženi CBRN událostí, NATO by mělo být schopno reagovat a asistovat při odstraňování následků použití ZHN. Tento pilír zahrnuje opatření pro podporu prevence následných útoků, snížení efektu způsobených CBRN incidentem, záchranu osob a materiálu, následné odstraňování následků s cílem uvést systém do původního stavu před použitím ZHN.

\section{1. 4 Civilnè vojenská spolupráce v oblasti CBRN}

Zatímco $v$ minulosti hlavním cílem snah NATO v boji proti CBRN hrozbám byla orientace na vojenské síly a prostředky protivníka, soudobé možné zneužití CBRN materiálu a ZHN teroristy, stejně jako CBRN události způsobené průmyslovými nebo prírodními

31 COE CBRN Vyškov. [cit. 1. 4. 2019]. Dostupné z: https://www.jcbrncoe.cz/index.php/organization-65 
katastrofami působící na civilní obyvatelstvo intenzivněji, jej dnes i v budoucnosti více činí více zranitelné. Pro zmírnění rizik je potřebná analýza zranitelnosti a rizik, která ukáže nedostatky v systému a plánech pro adekvátní civilní odezvu a stanoví možnou vojenskou podporu civilním autoritám.

Během vojenských operací je CBRN ochrana součástí procesu ochrany vojsk (Force Protection), ale $v$ současném bezpečnostním prostředí se nelze pouze zabývat vojenským aspektem operace. Zvažování samotných vojenských aspektů nepovede $\mathrm{k}$ úspěchu operace. Dosažení požadovaného konečného stavu vyžaduje komplexní přistup a koordinaci se všemi aktéry včetně vládních, mezinárodních a nevládních organizací. Poskytnutí silné CBRN ochrany ve prospěch obyvatelstva, území a jednotek redukuje a limituje efekt případné CBRN události. Snižení možných následků také přispívá k odrazení prípadných protivníků od použití ZHN nebo CBRN prostředků proti civilnímu obyvatelstvu, území a silám nebo infrastruktuře. Proto požadavky na civilně-vojenskou spolupráci znatelně vzrostly. Společný civilně-vojenský výcvik a cvičení posilují vzájemné vztahy a spolupráci v oblasti odstraňování následků a CBRN ochrany. Je třeba zvážit její úroveň, rozsah a hloubku pro každou organizaci, v každé fázi operace a na všech úrovních velení. Mechanismy pro nasazení společných civilně-vojenských jednotek NATO, sjednocení a plánování rozvoje civilních a vojenských schopností včetně mediálních operací by měly být prozkoumány a cvičeny. ${ }^{32}$

\section{ZAPOJENÍ MO A AČR DO PROCESU NEŠíŘENÍ ZHN}

Jak vyplývá z výše uváděných civilně-politických a vojenských aspektů z hlediska mezinárodního práva je garantem dodržování úmluv o nešíření ZHN Ministerstvo zahraničních věcí, přesto se tomto procesu podílí i Ministerstvo obrany.

V současné struktuře je na strategicko-politické úrovni tato problematika zpracovávána na Sekci obranné politiky a strategie MO (SOPS MO). SOPS MO se účastní pravidelných jednání seniorního výboru NATO - „NATO Committee on Proliferation“ (CP) vojenský formát, Výbor pro boj proti šíření jaderných zbraní. CP je hlavním poradním orgánem Severoatlantické rady pro šíření zbraní hromadného ničení (WMD) a jejich přidružených systémů, chemické, biologické, radiologické a jaderné ochrany. Výbor je zodpovědný za sdílení informací, rozvoj doktrín a koordinaci v otázkách prevence a reakce na šíření jaderných zbraní.

Na Generálním štábu AČR a v Armádě České republiky se problematikou nešíření ZHN zabývá sekce rozvoje sil MO, Odbor rozvoje pozemních sil, konkrétně oddělení chemického vojska (CHV). Zejména prosazováním závazků v oblasti budování schopností v oblasti CBRN ochrany, zaváděním standardů NATO pro CBRN Defence a přistoupením k doktrínám NATO v oblasti CBRN. Zapojením AČR do procesu Framework Nations Concept

32 Ref. 28 
$(\mathrm{FNC})^{33}$ je zabezpečena připravenost jednotek CHV pro rozšíření své působnosti i do oblasti nešíření ZHN.

AČR má vybudovanou a provozuje Armádní monitorovací sít (ARMS), která je součástí státní monitorovací sítě. Tato sít zabezpečuje trvalou kontrolu radiační situace na území ČR. Je provozována SÚJB. Ve spolupráci se SÚJB dále AČR provádí leteckou monitorovací službu nad územím ČR. Využitím této sítě a leteckého monitorování, Ize sledovat prípadný pohyb radioaktivního materiálu na území ČR.

Snaha o snížení počtu jaderných zbraní, zákaz chemických a biologických zbraní a jejich likvidace vedou k stabilizaci bezpečnostního prostředí nejen v Evropě ale i v celosvětovém měřítku. Z analýzy zapojení ČR v oblasti proliferace ZHN a dále s využitím výsledků závěrečné práce kurzu generálního štábu, ${ }^{34}$ Ize formulovat následující poznatky a závěry:

- ČR veškeré platné úmluvy v oblasti nešíření ZHN a jejich nosičů dlouhodobě beze zbytku plní.

- ČR a MO se podílí na prosazování politiky nešíření ZHN a jako člen mezinárodního společenství se účastní všech relevantních režimů kontroly zbrojení, odzbrojení a nešíření ZHN.

- Hlavním úkolem pro resort MO je především zajištování ochrany před účinky zbraní hromadného ničení a to jak ve prospěch vlastních tak i spojeneckých sil a jakožto součást integrovaného záchranného systému též ve prospěch civilního obyvatelstva.

- Zapojení resortu MO a AČR do procesu non-proliferace je možné v oblasti zpravodajské - INTEL podpora, rozvoj schopností dle NATO standardů v oblasti CBRN ochrany a zapojení př́ílušníků AČR do expertních týmů OPCW.

- V rámci NATO byl schválen koncept pro nešíření ZHN. Úkolem pro MO a AČR je jeho implementace do norem a předpisů včetně úpravy standardů pro chemické vojsko.

- Meziresortní spolupráce v oblasti nešíření ZHN je posuzována jako dostatečná a na dobré úrovni. Mezi státními organizacemi jako je SúJB a MO (AČR) se spolupráce začíná rozvíjet.

- Zkušenosti se zapojením AČR a MO do iniciativ non-proliferace ZHN jsou chápány pozitivně a snižují bezpečnostní hrozby a rizika pro ČR, vedou k větší transparentnosti a posilování důvěry. Jedná se především o rovinu politicko-strategickou. Na operačně-taktickém stupni je zapojení pouze v oblasti výměny informací a zkušeností.

- Pro AČR, je nezbytné udržovat znalosti a schopnosti ochrany před účinky ZHN. Přípravou velitelů a štábů na implementaci informačního managementu do procesu plánování s demonstrováním funkčních kapacit CBRN ochrany zabezpečit schopnost AČR vyčleňovat síly a prostředky do sil NRF (v rámci CJ CBRND TF, VJTF).

33 HAVEL, Ondřej a Antonín NOVOTNÝ, Možnosti rezortu obrany při prosazování konceptu framework nations. Vojenské rozhledy, 2016, 25 (4), s. 3-17. ISSN 1210-3292 (print), 2336-2995 (on-line). Dostupné z: http://vojenskerozhledy.cz/kategorie/moznosti-resortu-obrany

34 FOKT, Martin. Nástroje bezpečnostni politiky k zamezeni proliferace zbrani hromadného ničení. Závěrečná práce 35 . KGŠ. Brno, 2019. UO. 
- Pokračovat v budování vzájemné spolupráce v oblasti OPZHN s ostatními členy Aliance s využitím COE CBRN a Ústavu OPZHN Univerzity obrany.

- Předpokládaným přínosem pro AČR může být rozšíření znalostí příslušníků CHV v oblasti expertízy a verifikace zavedených kontrolních režimů zapojením do expertních týmů OPCW a využívání monitorovací sítě AČR pro potřeby SÚJB k monitorování radiační situace na území ČR.

Potřeba zapojení MO a AČR do procesu nešíření ZHN je charakterizována v rovině rozšířené spolupráce se státními úřady a implementace koncepcí NATO do norem a předpisů platných v AČR s dưrazem na zachování, rozvoj a případné rozšíření schopností jednotek chemického vojska.

\subsection{Doporučení a postupy pro zapojení ČR a AČR do mezinárodní spolupráce v oblasti zamezení proliferace ZHN}

Z analýzy zapojení ČR a MO do procesu nešírení ZHN, mezinárodní spolupráce v této oblasti, vyhodnocení strukturovaných rozhovorů ${ }^{35}$ a s využitím osobních znalostí a zkušeností z oblasti OPZHN vyplývají následující závěry a některá doporučení pro odpovědné orgány resortu pro další zapojení do mezirezortní a mezinárodní spolupráce v oblasti nešírení ZHN:

- Pokračovat v dosavadní spolupráci s MZV v oblasti nešíření ZHN. Vytvářet podklady pro jednání a vlastní účast na jednání vojenského výboru NATO „Committee on Proliferation“. Současná praxe je hodnocena jako dostačující.

- Podporovat mezinárodní úsilí v oblasti nešíření ZHN, smlouvy, iniciativy a programy představené OSN, EU, bilaterální dohody a pakty. Podpora zahraniční politiky a bezpečnostní politiky je jednoznačně zaměřena na dodržování závazných smluv a ujednání v oblasti nešíření ZHN.

- Pokračovat v zavádění opatření vyplývajících z NATO COMPREHENSIVE CHEMICAL, BIOLOGICAL, RADIOLOGICAL, NUCLEAR (CBRN) DEFENCE CONCEPT. Tento koncept pomáhá jednotlivým členským státům NATO ujednotit přistup k této problematice. Zavedením standardů NATO do norem a předpisů pro AČR přispěje $k$ možnosti vyčlenění jednotek CHV i do operací spojených s bojem s nelegálním šířením ZHN - popř́padě i možnosti koaliční spolupráce v účelových uskupeních vytvářených na bázi eNRF (CJ CBRN TF) a podobně.

- Přistoupit k implementaci NATO konceptu WEAPONS OF MASS DESTRUCTION DISABLEMENT FUNCTIONAL CONCEPT a podílet se na přípravě nové NATO doktríny v rámci IMS. Implementace těchto norem rozšírí možnosti nasazení jednotek chemického vojska v operacích NATO a EU na stejném principu jako u předchozího bodu.

- Jelikož problematika nešíření ZHN je věcí širšího zapojení všech zainteresovaných aktérů, je nezbytné do budoucna zařadit do strategických plánů a operací novou

35 Ref. 32, str. $44-47$ 
kategorii vojenských příspěvků pro řešení problematiky nešíření ZHN tzv. Operaci na zneškodnění ZHN.

- Získávání informací je základním kamenem pro úspěšné působení v oblasti nešíření ZHN, proto je nutné vytvořit předpoklady pro úspěšné propojení vojenského zpravodajství, speciálních sil a odborníků za oblast CBRN (Reachback and fusion) v podmínkách AČR s přesahem na mezinárodní struktury NATO, OPCW atd. Fúze informací, znalostí a technického řešení bude přispívat k nalezení nejvhodnější metody a postupu při řešení problematiky nešíření ZHN. Nedílnou součástí tohoto procesu je NATO CBRN COE, které v této oblasti může zabezpečit stálou poradenskou službu pomocí sekce CBRN Reachback.

- Součást procesu nešíření ZHN je i kontrolní a monitorovací činnost orgánů státní správy. Je proto nezbytné vytvořit podmínky pro prohloubení spolupráce mezi SÚJB, který je za oblast kontroly odpovědný, a resortem obrany. Současně lze využít zkušenosti a odborné znalosti pracovníků SúJB pro zkvalitnění přípravy a výcviku specialistů CHV v oblasti detekce a analýzy.

- Pokračovat v prohlubování spolupráce se SÚJB v oblasti monitorování radiační situace na území ČR, $\mathrm{k}$ tomu využívat prostředky armádní radiační monitorovací sítě. Pro odhalování ilegálních transferů radioaktivního materiálu přes území ČR Ize využít prostředky leteckého radiačního monitorování.

- V oblasti prípravy a výcviku jednotek CHV a v rámci př́pravy chemického zabezpečení úkolových uskupení, sil eNRF a HRF se zaměřit na výcvik a přípravu speciálních týmů zabývajících se problematikou detekce a analýzy neznámých látek s využitím současných kapacit a schopností SIBCRA týmů a laboratorních kompletů, nadále pokračovat ve snaze o dosáhnutí forenzních schopností odběru a analýzy u vybraných týmů 31. pluku radiační, chemické a biologické ochrany.

- Vhodným prostředkem pro zapojení AČR do problematiky nešíření ZHN je projekt Framework Nations Concept (FNC), do kterého se AČR již zapojila. V oblasti CBRN je tato iniciativa podporována především Spolkovou republikou Německo, Českou republikou a Slovenskem. Tento projekt napomáhá a podporuje rozvoj schopností v oblasti CBRN, rozšiřuje možnosti členských států NATO v oblasti budování a sdílení CBRN schopností.

- V neposlední řadě je třeba využít možnost zapojení vybraných příslušníků CHV do expertních týmů OPCW. Tato možnost povede k získání nových poznatků a zkušeností z oblasti sdílení informací, detekce a analýzy chemických látek.

\section{ZÁVĚR}

Nešíření zbraní hromadného ničení a kontrola odzbrojení je z pohledu mezinárodního společenství považováno za základní aspekt zachování míru, rozvoje globální spolupráce a snižování napětí mezi hlavními aktéry na poli ekonomickém a politickém. Česká republika jako signatář a zakládající člen OSN, aktivní člen EU a NATO k problematice nešíření ZHN přistupuje velmi zodpovědně. V oblasti chemických zbraní je ČR zakládajícím členem OPCW a prosazuje dosažení univerzality Úmluvy, důslednou realizaci ustanovení Úmluvy 
v národních legislativních systémech smluvních stran, sjednocení pravidel a technických náležitostí pro hlášení (deklarace) o exportu, importu a výrobě chemických látek a zvyšování efektivity činnosti OPCW, včetně účinnosti a kvality inspekcí. Mezinárodní smlouvy a bilaterální dohody v oblasti jaderné bezpečnosti, zákazu chemických a biologických zbraní jsou důsledně dodržovány i přesto, že ČR není primárním objektem těchto smluv a dohod. Zapojení ČR, MO a AČR do mezinárodní spolupráce a do systému kolektivní obrany NATO je základním východiskem pro zajištění obrany a bezpečnosti ČR, což je zakotveno v Obranné strategii z roku 2017. Tento aspekt umožňuje rozvíjet a realizovat projekty nebo činnosti v oblasti OPZHN, které by byly pro jednotlivé státy technologicky, či zdrojově náročné.

Zapojení MO a AČR do struktur NATO umožňuje ovlivňovat strategické rozhodování $\checkmark$ oblasti OPZHN a tím podporovat současné trendy týkající se forenzní analýzy, odběru CBRN vzorků a přijímání nových trendů v oblasti odstraňování následků použití ZHN. Podporou odzbrojovacích a kontrolních mechanismů v oblasti nešírení ZHN a jejich nosičů, ČR a MO naplňuje svoji ambici v oblasti OPZHN jako vedoucího národa. Přijetím konceptů NATO zabývajících se problematikou komplexního přístupu k ochraně pred účinky ZHN a pro zneschopnění ZHN je položen základní kámen k udržování současných schopností a budování nových schopností chemického vojska v souladu s požadavky koaličních partnerů na společnou obranu. Dalším vhodným prostředkem pro zapojení AČR do problematiky OPZHN je účast v projektu FNC, kde spolu se Spolkovou republikou Německo zahajuje ČR proces sdílení schopností v oblasti OPZHN ve prospěch společné obrany EU.

Autoři: $\quad$ Pplk. gšt. Ing. Martin Fokt, narozen v roce 1968. V roce 1991 ukončil Vojenskou vysokou školu pozemního vojska generála Ludvíka Svobody ve Vyškově, obor vojensko-inženýrský vojenská chemie. V roce 2002 absolvoval praporní velitelský kurz pro důstojníky chemického vojska v USA. Od roku 1991 do roku 2008 působil v různých velitelských a štábních pozicích u jednotek chemického vojska. V letech 2008 až 2011 působil ve strukturách NATO Land Component Command (Force Command) Headquarters v Heidelbergu, Německo. Po návratu ze zahraniči působil v letech 2011 až 2017 na Velitelství brchbo pro ARRC. Od června 2017 zastává funkci Náčelníka štábu 31. pluku radiační, chemické a biologické ochrany v Liberci. V březnu 2019 ukončil studium Kurzu generálního štábu na Univerzitě obrany Brně.

Ing. Antonín Novotný, Ph.D., narozen 1963. V roce 1985 ukončil Vysokou vojenskou školu pozemního vojska ve Vyškově a poté do roku 1988 vykonával velitelské funkce. V období 1988-1991 absolvoval postgraduální studium obor velitelsko-štábní, specializace zpravodajská, a následně v letech 1991-2008 působil v různých funkcích u Vojenského zpravodajství. V letech 2008-2010 pracoval jako obranný poradce ve velitelství NATO při stálé delegaci České republiky při NATO a Stálém zastoupení České republiky při Evropské unii v Bruselu. V letech 2011-2012 akademický pracovník skupiny bezpečnostních studií, katedry celoživotního vzdělávání Univerzity obrany 
(UO) v Brně. Od listopadu 2012 pracuje jako odborný asistent Centra bezpečnostních a vojenskostrategických studií UO.

pplk. doc. Ing. Pavel OTŘísAL, Ph.D., MBA, narozen v roce 1972. VVŠ PV ve Vyškově absolvoval v roce 1994. $V$ roce 2011 ukončil profesní vzdělávací program „Public relations". V roce 2012 ukončil doktorské studium oboru. $V$ roce 2015 ukončil habilitační rízení a byl jmenován docentem v oboru Ochrana vojsk a obyvatelstva. Prošel velitelskými funkcemi na stupni rota a štábními funkcemi na stupni prapor a brigáda. $V$ roce 2005 nastoupil na Ústav OPZHN Univerzity obrany ve Vyškově na systemizované misto odborného asistenta oddělení chemického vojska, kde působí doposud. $V$ rámci pedagogické činnosti se věnuje problematice bojového a operačního použití jednotek, útvarů a svazku chemického vojska.

Jak citovat: FOKT, Martin and Antonín NOVOTNÝ, Pavel OTŘíSAL. Některé nástroje bezpečnostní politiky české republiky k zamezení proliferace jaderných a chemických zbraní. Vojenské rozhledy. 2019, 28 (3), 128-147. ISSN 1210-3292 (print), 2336-2995 (on-line). Available at: www.vojenskerozhledy.cz. 


\section{Recenze monografie autora - Daniel P. Bagge}

\section{Miroslava Pavlíková}

\section{UNMASKING MASKIROVKA: RUSSIA'S CYBER INFLUNCE OPERATIONS}

Unmasking Maskirovka: Russia's Cyber Influnce Operations je knižní prvotinou současného kybernetického atašé za Českou republiku pro Spojené státy americké a Kanadu a bývalého ředitele odboru kybernetických bezpečnostních politik Národního úřadu pro kybernetickou a infomační bezpečnost Daniela P. Bagge. Kniha o 251 stranách vydaná nakladatelstvím Defence Press není výstupem $z$ jeho aktivit $v$ úradu nebo reprodukcí politik České republiky $k$ tématu informačních operací, ale vlastním výzkumným dílem založeném na zájmech autora. Že téma autora zajímá či jej jednoduše "baví", je při čtení knihy rozpoznatelné a umožňuje $i$ čtenáŕi toto nadšení s autorem sdílet. Kniha si najde čtenáře $v$ několika oblastech. Jako užitečná, stručná a jasná príručka $v$ aktuálním, zajímavém, ale i spletitém tématu poslouží policy makerům, akademikům, studentům bezpečnostních studií nebo vojenských oborů, ale rozhodně i vyšším vojenským důstojníkům.

Unmasking maskirovka nabízí nejprve teoretický diskurz pro dnes často skloňovanou problematiku ruské informační války, který je autorem prokládán kontrasty s historickými koncepty vojenské vědy. Autor prezentuje také jakousi univerzalitu těchto konceptů, kdy upozorňuje na jejich platnost v současnosti. Svůj př́stup k práci s daty popisuje jako doktrinální a historickou analogii konceptů pro digitální éru. Druhá část knihy poté překvapuje autorovými originálními analytickými výstupy a návrhem nástroje i pro budoucí analýzy.

$\checkmark$ úvodní kapitole se autor věnuje vlivovým operacím, zejména jejich teoretickému vymezení a důležitosti $v$ dnešním vojenství. Zdůrazňována je potřeba širší perspektivy pro operování s kyberprostorem, nelpění na technikáliích, ale vymezení stejného prostoru i sociálně psychologické sfére. Následně se věnuje klamání (deception) a souvisejícím 
termínům jako je klamání politické nebo vojenské. Autor se dostává též k vysvětlení titulkové maskirovky.

Na dalších stranách se Bagge posouvá k hlavnímu aktérovi celé knihy - Ruské federaci a jejím postojům $\mathrm{k}$ operacím v kyberprostoru. Zmiňován je koncept aktivních opatření (active measures) a následné dovedení čtenáře až po pro autora podstatný teoretický model reflexivní kontroly.

Pro čtenáře je osvěžujícím překvapením, že už po pár stránkách teoretických diskuzí přichází autor s prvními analytickými vstupy. Ocenit se dá zejména tendence stavět teorii či tvrdá data do kontrastu s realitou a dobře známými události, které pokud se neobjevily $v$ médiích, tak o nich má povědomí vědecká či bezpečnostní sféra. Tato skutečnost zpřístupňuje diskurz knihy a nenudí. $V$ podobném duchu se nese i část představující ruské strategické dokumenty a jejich manipulaci s informačním bojem. Bagge vybírá jejich podstatné části a komentuje je s pomocí reálií či dat od jiných autorů. Formát těchto mikroanalýz není nijak přesně daný, nicméně Baggeho cílem není podat vyčerpávající akademickou analýzu.

Předěl mezi řekněme úvodní a hlavní analytickou částí tvoří kapitola Cyber Relation to Information Superiority and Reflexive Control. Kapitola působí dojmem samostatné jednotky, která by dobře plnila svoji roli na kterémkoliv místě v knize, spíše však v úvodu. Co akademického čtenáře zaujme, je absence odkazů na zdroje. Nabízí se tak vysvětlení, že autor vycházel ze svých expertních znalostí.

Hlavní analytická část s nadpisem Reflexive Control: Cyber Related Examples pracuje $s$ popisem nástrojů dle S.A. Komova. Je zde opět velmi šikovně propojena teorie s praktickými príklady, tentokrát se směřováním na ukrajinský konflikt a roli Ruska v něm. Znovu se odkáži na roli akademického čtenáře, který by možná ocenil hlubší operacionalizaci a triangulaci zdrojů, avšak pro účely knihy je autorovo vymezení dostačující. Výstupem kapitoly je návrh analytického nástroje DOPES, který bude hodnotit několik elementů kybernetických operací (Distraction, Deception, Divisison, Detterence, Overload, Paralysis, Pacification, Provocation, Pressure, Exhaustion, Suggestion). Ten pak sám v následující kapitole aplikuje na ukrajinský konflikt, tedy jednotlivé kampaně v jeho rámci. Výstup je působivou ukázkou toho, jak Ize systematicky analyzovat těžce uchopitelné a přisuzovatelné události. Sám autor přiznává, že se jedná jenom o ilustrativní výčet a rozhodně ne absolutní popis, což ovšem v této oblasti ani není možné. Hlavním přínosem je návrh analytického rámce, který může být dále používán a upravován i na odborné úrovni.

Závěrečná část není, jak by se možná nabízelo, soupisem doporučení pro policy makery jak proti ruským vlivovým operacím postupovat. Bagge naopak přichází s tzv. „must-nots", které představují pro ruský režim jakési červené linie, jež nesmí překročit, aby byl zachován. Chytrý čtenář však pochopí, že mohou zároveň sloužit jako pomysIný návod k tvorbě protiopatření.

Snadné proplouvání knihou možná pro někoho naruší méně kvalitní ilustrační obrázky, zejména pak obrázek č. 5 na straně 129 . Hnidopichy pak může rozhodit ponechání samohlásek na koncích vět a anarchie v zarovnání odstavců v seznamu zdrojů. Nakladatel zřejmě tak své přednosti prokazuje obsahem.

Unmasking maskirovka by se měla stát první volbou pro policy makery a vojenský personál, který se snaží pochopit a zorientovat v aktuální problematice ruských vlivových operací. I věčně zaneprázdnění a na krátké analýzy zvyklí čtenáři (zejm. vyšší státní 
úředníci) zvládnou knihu svižně projít a získat vše potřebné, aby mohli se znalostí tématu reagovat na aktuální strategické výzvy. Kniha by také mohla plnit funkci doporučené literatury pro studenty vojenských a bezpečnostních oborů, kterým nabídne adekvátní a snadno stravitelný exkurz do ruských vlivových operací.

Autor: $\quad$ Mgr. Miroslava Pavlíková, narozena v roce 1990. V letech $2010-2013$ absolvovala bakalářský studijní program Politologie a Bezpečnostní a strategická studia. V období 2013 - 2016 pak magisterský obor Bezpečnostních a strategických studií. Zároveň v roce 2014 studovala program Politics, History and International Relations na Department of PHIR v Loughborough University ve Velké Británii. V současnosti studuje doktorský program Politologie na Fakultě sociálních studií Masarykovy univerzity v Brně. 


\section{OBSAH}

Džihádističtí zahraniční terorističtí bojovníci: soudobé hrozby a výzvy ve středovýchodní Evropě

Miroslav Mareš

Náboženský extremismus jako příčina ozbrojených konfliktů: indikátory a systémy včasného varování

Josef Kraus

Role neokolonialismu ve vývoji bezpečnostní situace v Afghánistánu

Martin Havlík

Obléhání Marawi, impulz změnit schopnosti filipínských ozbrojených sil

Libor Kutěj

Význam programu rozvoje mad’arských ozbrojených sil Zrínyi 2026

Olivér Balogh

Unifikace Ozbrojených sil Bosny a Hercegoviny - proces sjednocování.

Věra Stojarová

Informační a psychologické operace jako výzva pro bezpečnost a obranu

Petra Vejvodová

Analýza a model systému přípravy odborníků kybernetické obrany.

Petr Františ, Jan Hodický

Př́lohy

Příprava občanů $\mathbf{k}$ obraně státu

Miroslav Jurenka

Některé nástroje bezpečnostní politiky České republiky k zamezení proliferace jaderných a chemických zbraní

Martin Fokt, Antonín Novotný, Pavel Otřisal

Recenze monografie autora - Daniel P. Bagge 


\section{CONTENTS}

Jihadist Foreign Terrorist Fighters: Contemporary Threats and Challenges in East Central Europe

Miroslav Mareš

Religious Extremism as a Cause of Armed Conflicts: Indicators and Early Warning Systems

Josef Kraus

The role of neo-colonialism in the Evolution of Security Situation in Afghanistan .... 26 Martin Havlík

The Siege of Marawi, the impulse to change the capabilities of the Philippine armed forces

Libor Kutěj

The Importance of the Zrínyi 2026 Defence and Military Development Program

Olivér Balogh

Unifying the Armed Forces of Bosnia and Herzegovina - mission completed?

Věra Stojarová

Information and Psychological Operations as a Challenge to Security and Defence

Petra Vejvodová

Analysis and model of Cyber security corps professional development

Petr Františ, Jan Hodický

\section{ENCLOSURE}

Preparing Citizens to Defend the State

Miroslav Jurenka

Some Tools of the Czech Republic Security Policy to Prevent Proliferation of Nuclear and Chemical Weapons

Martin Fokt, Antonín Novotný, Pavel Otřisal

Review of the Author's Monograph - Daniel P. Bagge

Miroslava Pavlíková 


\section{Časopis VOJENSKÉ ROZHLEDY}

čtvrtletník

Vydává:

Ministerstvo obrany České republiky, Tychonova 1, 16001 Praha 6 - Dejvice

Vydávající instituce:

Univerzita obrany, Kounicova 156/65, 66210 Brno

IČO: 60162694

Vojenské rozhledy č. 3/2019

Ročník: XXVIII. (LX.)

Datum předání do tisku: 9. záŕí 2019

Rozšiřuje:

OKP MO, distribuce, Rooseveltova 23, 16105 Praha 6

Olga Endlová, tel. 973215 563, endlovao@army.cz

Redakce:

Ing. Petr Koziel, telefon: 973443499

E-mail: vojenskerozhledy@unob.cz

\section{Redakční rada:}

Ing. Ján Spišák, Ph.D. (předseda), PhDr. Miloš Balabán, Ph.D., pplk. Marco Biagini, Ph.D., prof. Mgr. Oldřich Bureš, Ph.D., M. A., doc. PhDr. Felix Černoch, CSc., plk. Florian Circiumaru, Ph.D., Mgr. Lukáš Dyčka, Ph.D., doc. PhDr. Jan Eichler, CSc., Mgr. et. Mgr. Jakub Fučík, Ph.D., prof. Dr. hab. Artur Gruszczak, plk. gšt. doc. Ing. Vladan Holcner, Ph.D., Ing. Vladimír Karaffa, CSc., prof. Ing. Aleš Komár, CSc., PhDr. Tomáš Kopečný, Mgr. Josef Kraus, Ph.D., brig. gen. Ing. Miloslav Lafek, prof. Juha-Matti Lehtonen, Ph.D., Ing. Vojtěch Němeček, Ph.D., plk. gšt. Ing. Tomáś Novotný, Ph.D. MSc., Mgr. Martin Riegl, Ph.D., plk. Chris Rogers, MA, MMAS., doc. Hofrat Univ. Dr. Erwin Schmidl, Ph.D., Dr. hab. Zdzislaw Sliwa, RNDr. Pavel Štalmach, MBA, Ing. Miroslav Šuhaj, Ph.D., Mgr. et Mgr. Lukáš Tichý, Ph.D.

\section{Tajemník redakční rady:}

Ing. Petr Koziel

Sídlo redakce: Kounicova 65, 66210 Brno

Adresa pro zasílání pošty:

Vojenské rozhledy - redakce, Kounicova 156/65, 66210 Brno

Časopis Vojenské rozhledy v elektronické podobě naleznete na:

http://www.vojenskerozhledy.cz/

\section{Časopis je evidován:}

- v evropské databázi ERIH PLUS,

- v seznamu recenzovaných neimpaktovaných periodik vydávaných v České republice

- v mezinárodní databázi Index Copernicus Journals Master List 2015

- v katalogu Národní knihovny České republiky

- v databázi Central and Eastern European Online Library GmbH (CEEOL)

- $v$ databázi Directory of Open Access Journals (DOAJ)

Grafická úprava: Adéla Zemanová

Tiskne: VGHMÚr 'obruška

Evidenční číslo: MK ČR E 6059

Identifikační číslo: ISSN 1210-3292 (print), ISSN 2336-2995 (on-line)

doi: 10.3849/2336-2995 